RENATO PEREIRA DA COSTA GERGER

Fisiologia e metabolismo placentário por canulação cordonal em gestações de bovinos normais, FIV e clonados 


\section{Fisiologia e metabolismo placentário por canulação cordonal em gestações de bovinos normais, FIV e clonados}

Tese apresentada ao Programa de PósGraduação em Anatomia dos Animais Domésticos e Silvestres da Faculdade de Medicina Veterinária e Zootecnia da Universidade de São Paulo para obtenção do título de Doutor em Ciências

\section{Departamento:}

Cirurgia

Área de Concentração:

Anatomia dos Animais Domésticos e Silvestres

Orientador:

Prof $^{\mathrm{a}}$. Dr ${ }^{\mathrm{a}}$. Maria Angélica Miglino

Co-orientador:

Prof. Dr. Marcelo Bertolini 
Autorizo a reprodução parcial ou total desta obra, para fins acadêmicos, desde que citada a fonte.

\section{DADOS INTERNACIONAIS DE CATALOGAÇÃO-NA-PUBLICAÇÃO}

(Biblioteca Virginie Buff D’Ápice da Faculdade de Medicina Veterinária e Zootecnia da Universidade de São Paulo)

Tese (doutorado) - Universidade de São Paulo. Faculdade de Medicina Veterinária e Zootecnia. Departamento de Cirurgia, São Paulo, 2010.

Programa de Pós-Graduação: Anatomia dos Animais Domésticos e Silvestres.

Área de concentração: Anatomia dos Animais Domésticos e Silvestres.

Orientador: Profa. Dra. Maria Angélica Miglino.

Co-orientador: Prof. Dr. Marcelo Bertolini.

1. Bovinos. 2. Produção In Vitro de Embriões. 3. Cultivo Celular. 4. Clonagem. 5. Síndrome dos neonatos anormais. I. Título. 


\section{UNIVERSIDADE DE SÃO PAULO \\ Faculdade de Medicina Veterinária e Zootecnia \\ Comissão Bioética}

\section{CERTIFICADO}

Certificamos que o Projeto intitulado "Fisiologia e metabolismo placentário por canulação cordonal em gestações de bovinos normais, FIV e clonados", protocolado sob o n⿳902/2006, utilizando 30 (trinta) bovinos, sob a responsabilidade da Profa. Dra. Maria Angélica Miglino, está de acordo com os princípios éticos de experimentação animal da Comissão de Bioética da Faculdade de Medicina Veterinária e Zootecnia da Universidade de São Paulo e foi aprovado em reunião do dia 17/05/2006.

(We certify that the Research "Physiology and placental metabolism by cordonal canulation in pregnancies of normal, IVP and cloned cattle", protocol number 902/2006, utilizing 30 (thirty) bovines, under the responsibility of Profa. Dra. Maria Angélica Miglino, agree with Ethical Principles in Animal Research adopted by Bioethic Commission of the Faculty of Veterinary Medicine and Zootechny of University of São Paulo and was approved in the meeting of the day 05/17/2006).

São Paulo, 18 de maio de 2006

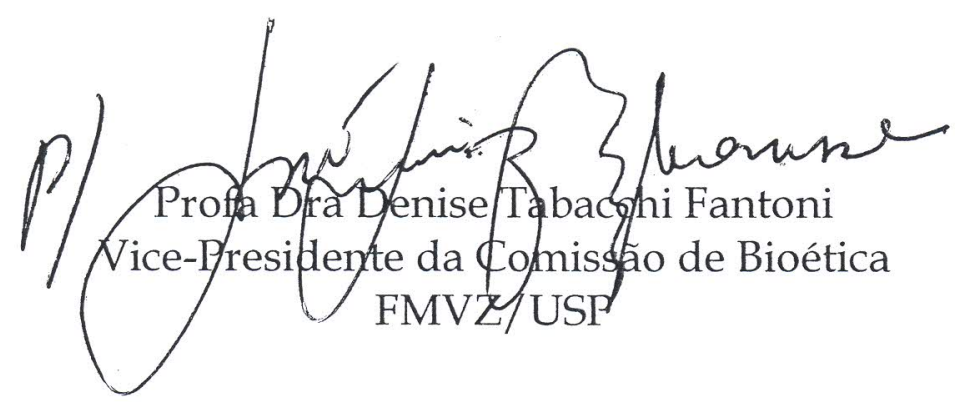




\section{FOLHA DE AVALIAÇÃO}

Nome: GERGER, Renato Pereira da Costa

Título: Fisiologia e metabolismo placentário por canulação cordonal em gestações de bovinos normais, FIV e clonados

Tese apresentada ao Programa de PósGraduação em Anatomia dos Animais Domésticos e Silvestres da Faculdade de Medicina Veterinária e Zootecnia da Universidade de São Paulo para obtenção do título de Doutor em Ciências

Data: 29/04/2010

\section{Banca Examinadora}

Prof. Dr

Instituição:

Assinatura:

Julgamento:

Prof. Dr

Instituição:

Assinatura: Julgamento:

Prof. Dr

Instituição:

Assinatura: Julgamento:

Prof. Dr Instituição:

Assinatura: Julgamento:

Prof. Dr Instituição:

Assinatura: Julgamento: 
DEDICATÓRIA

Dedico esta Tese às pessoas essenciais na condução e conclusão de mais esta etapa da minha vida. Minha amada Alida, meus amados pais Antonio e Maria do Carmo, e ao querido mestre e amigo Marcelo. 


\section{AGRADECIMENTO}

A Deus, por ter me abençoado com uma vida repleta de beleza e alegrias.

À minha amada esposa Alida, sempre paciente, generosa, compreensiva e companheira em todos estes anos. Difícil colocar em palavras tudo o que há para se dizer quando penso em minha mulher. A única certeza que tenho, é de que sem ela não teria concluído este projeto. Meu eterno amor e gratidão.

Aos meus pais Antonio e Maria do Carmo, exemplos de amor, caráter e referência para toda a minha vida. E que em todos os momentos me apoiaram e puderam me proporcionar uma qualidade de vida e de educação, as quais serei eternamente grato.

Ao mestre e Amigo Marcelo, uma pessoa iluminada e que poucos tem a sorte e a chance de conhecer em uma vida inteira. Eu sou muito sortudo, pois nestes anos conheci um exemplo de pai, marido, amigo e profissional que pretendo seguir pelo resto de minha vida. Uma pessoa que me ensinou a fazer o melhor em tudo que eu pretenda fazer. Esta Tese meu querido mestre, não sairia sem a tua ajuda, conhecimento e participação integral em todos os momentos. Obrigado!

Ao meu irmão Fernando, fonte inesgotável de risadas e que me remete aos melhores momentos de minha infância.

À toda a minha família pelo carinho e apoio incondicionais nestes anos, em especial à Valeria e Vittoria, que me acolhem há oito. Aos meus amores de Curitiba; tio Écio, tia Elô, Ana Paula e Luis Felipe que me abrigaram nas incontáveis idas e vindas deste doutorado. E à minha querida tia Tchutchu, pela alegria que sempre transmitiu quando a olhei.

Aos meus avôs e avós, vivos em minhas lembranças.

Dizem que amigo é o irmão que você escolheu enquanto viveu. Sou eternamente grato e honrado pelos irmãos de berço, colégio e faculdade escolhidos nesta vida.

À querida professora Angélica por ter permitido que eu desenvolvesse este trabalho em terras distantes, e pela confiança sempre depositada.

Ao querido professor Alceu Mezzalira por ter me acolhido em seu laboratório e feito me sentir em casa. Muito obrigado querido mestre.

Ao professor Arnaldo Dinis Vieira, pelo apoio, compreensão e ensinamentos recebidos. Ao professor Carlos Eduardo Ambrósio, pela ajuda imediata quando precisei. Aos professores e colaboradores estrangeiros, Dr. Calvin Ferrell (USDA-EUA) e o Dr. Roberto Sainz (UC Davis-EUA) pela ajuda nos procedimentos do experimento piloto deste trabalho.

Ao amigo Ivens, pela imensa ajuda em todos os momentos e pelo companheirismo.

Aos colegas e amigos de laboratório em Lages, por tudo o que fizeram nesta caminhada, são eles: Eduardo, Joana, Leonardo, Monalyza, Fabiano Cruz, Saul, Zago, Luciana, Mônica, Lain, Fabiano Vieira, Jamir, Matheus, Murilo, Pedro, Luis, Renata, Juliana, 
Luiz Miguel e Camila. Olhando para trás, vejo que de uma forma ou de outra, cheguei aqui por vossa causa.

À Fabi, Bira e Júlia, pelo carinho, conselhos, acolhida e ajuda inesgotável. ensinamentos.

À toda família Bertolini, em especial à querida Luciana, pelo carinho e

Ao amigo Lucio, pelas boas conversas e ótimos momentos juntos.

Aos colegas da anatomia pelo companheirismo e cumplicidade nestes anos.

Ao Nando e Seu João na Central Santa Rita - Itajaí e ao Fernando na Epagri - Lages, sem vocês, definitivamente, este trabalho não seria possível.

Aos frigoríficos Nova Era, Fox, El Golli, Verdi, e Pamplona que proporcionaram o uso de suas instalações e matéria-prima para a realização deste experimento.

À FMVZ-USP, minha casa há 10 anos, local que me proporcionou uma educação de qualidade e que muito colaborou na minha formação tanto profissional quanto pessoal.

Ao CAV-UDESC, EPAGRI-Lages e UNIFOR-CE pelo apoio em diversos aspectos e circunstâncias.

À FAPESP e CAPES pelo apoio financeiro. 


\section{RESUMO}

GERGER, R. P. C. Fisiologia e metabolismo placentário por canulação cordonal em gestações de bovinos normais, FIV e clonados. [Placental physiology and metabolism by cordonal canulation in normal, IVF and cloned bovine concepti]. 2010. 172 f. Tese (Doutor em Ciências) - Faculdade de Medicina Veterinária e Zootecnia, Universidade de São Paulo, São Paulo, 2010.

O desenvolvimento dos sistemas de produção de embriões por fecundação in vitro (FIV) ou transferência nuclear com células somáticas (TNCS) em diversas espécies animais, em especial a bovina, acarretou na manifestação de anormalidades de desenvolvimento in vivo, com a placenta sendo considerada o fator determinante no aparecimento destes distúrbios durante a gestação. A hipótese geral deste trabalho é de que alterações na formação da placenta, decorrentes das manipulações embrionárias in vitro, resultam em elevadas perdas no terço inicial e em anormalidades fetais e placentárias no terço final da gestação, incluindo um crescimento compensatório dos fetos por uma perda da capacidade de regulação da restrição placentária, elevando o fluxo total de nutrientes no sentido materno-fetal. Sendo assim, este estudo foi dividido em Capítulos, buscando-se avaliar os efeitos de algumas variáveis biológicas e técnicas na produção de embriões in vitro por TNCS, e de comparar o desenvolvimento de prenhezes estabelecidas com embriões produzidos in vivo (Controle), in vitro por fecundação (FIV) e in vitro por transferência nuclear (TNCS), pela avaliação de dados morfométricos, morfológicos e bioquímicos coletados em distintos momentos da gestação. No Capítulo 1, o desenvolvimento in vitro de embriões clonados foi comparado entre células somáticas de duas fêmeas geneticamente distintas (Nelore vs. Crioula Lageana), e entre três intervalos de confluência celular, estabelecidos previamente ao procedimento de clonagem, do mesmo animal. As melhores taxas foram obtidas com a utilização de células da fêmea Nelore, e da utilização de células com elevada confluência em cultivo. No Capítulo 2, comparou-se o efeito de dois intervalos de fusão-ativação e da agregação ou não de embriões no momento do cultivo, no desenvolvimento in vitro e in vivo destes embriões clonados. A agregação dos embriões e um maior intervalo entre fusão-ativação promoveram um incremento na produção de blastocistos. Contudo, estes não se apresentaram mais desenvolvidos ou com melhor qualidade, e também não influenciaram nas taxas de prenhez ou de manutenção das mesmas. No Capítulo 3, prenhezes dos grupos Controle, FIV e TNCS foram comparadas pela avaliação de dados morfométricos e bioquímicos coletados em 
distintos momentos da gestação. Este experimento demonstrou que as diferenças entre os grupos experimentais ocorreram desde as análises iniciais, com os grupos in vitro apresentando menores taxas de prenhez, e com o grupo TNCS tendo as maiores perdas gestacionais. As imagens obtidas por ultrasonografia aos 51 dias revelaram conceptos in vitro retardados em seu desenvolvimento, mas com um crescimento compensatório posterior, já que as prenhezes produzidas in vitro, e especialmente as do grupo TNCS, sustentaram não só maiores conceptos e com maiores anormalidades aos 225 dias de gestação, como também apresentaram um maior acúmulo de substratos energéticos no sistema fetal, particularmente de frutose no alantóide. No Capítulo 4, foram comparados os resultados de produção de embriões clonados e do estabelecimento de prenhezes em um período de produção de 28 meses, divididos em três momentos. A compilação dos períodos de rotinas de trabalho em clonagem bovina demonstrou o efeito da experiência e da aquisição de competência técnica sobre os resultados de produção in vitro de embriões por TNCS, com repercussão direta no desenvolvimento in vivo posterior.

Palavras-chave: Bovinos. Produção In Vitro de Embriões. Cultivo Celular. Clonagem. Síndrome dos neonatos anormais. 


\begin{abstract}
GERGER, R. P. C. Placental physiology and metabolism by cordonal canulation in normal, IVF and cloned bovine concepti. [Fisiologia e metabolismo placentário por canulação cordonal em gestações de bovinos normais, FIV e clonados]. 2010. 172 f. Tese (Doutor em Ciências) - Faculdade de Medicina Veterinária e Zootecnia, Universidade de São Paulo, São Paulo, 2010.
\end{abstract}

The in vitro production (IVP) of embryos by in vitro fertilization (IVF) or somatic cell nuclear transfer (SCNT) in many species, especially in cattle, is usually associated with abnormalities during in vivo development, with the placenta being implicated as the determining factor in the appearance of the disturbances during gestation. The general hypothesis of this study is that alterations in placenta formation, as a consequence of early in vitro embryo manipulations, results in high gestation losses during the first trimester and fetal and placental abnormalities in the last trimester of gestation, including the occurrence of a compensatory fetal growth due to a reduced placental-fetal growth-restricting effect, which increases the total materno-fetal nutrient flux in late pregnancy. This study aimed to evaluate some of the biological and technical effects on the IVP of embryos by SCNT, and also to compare the development of pregnancies established with embryos produced either in vivo (Control), or in vitro by in vitro fertilization (IVF) or by nuclear transfer (SCNT), by the evaluation of morphometric, morphologic and biochemical data collected at distinct time points in gestation. In Chapter 1, the in vitro development of cloned embryos was compared between somatic cells of two genetically different females (Nelore vs. Crioula Lageana), and between three cell confluence intervals, established prior to the cloning procedure of the same animal. The best results were achieved using cells from the Nelore female and also with cells on the highest confluence level on culture. In Chapter 2, the effects of two fusion-activation intervals and the use or not of embryo aggregation during in vitro culture were compared by evaluating the in vitro and in vivo developmental potential of resulting embryos. The embryo aggregation and a higher fusion-activation interval promoted an improvement in blastocyst yield. However, those embryos were neither more advanced in development nor better in morphological quality, having no influence on subsequent pregnancy rates or pregnancy losses. In Chapter 3, Control, IVF and SCNT pregnancies were compared by the evaluation of morphometric and biochemical data collected at distinct moments in gestation. This experiment demonstrated that differences occurred between the three groups of embryos from 
the beginning of the analyses; the in vitro-produced groups had lower pregnancy rates, with the SCNT group showing the highest pregnancy losses. The analyses of the sonograms on Day 51 of pregnancy revealed a growth retardation pattern for the in vitro concepti, having a compensatory development up to late pregnancy, as in vitro-derived pregnancies, special in the SCNT group, sustained heavier concepti with a wider spectrum of abnormalities on day 225 of gestation. In addition, the SCNT pregnancies demonstrated a greater accumulation of substrates in the fetal system, particularly fructose on the allantoic fluid. Finally, in Chapter 4, results obtained from a retrospective analysis of bovine embryo production by cloning and subsequent pregnancy rates were compared between three equal periods within a range of 28 months. The comparison of the bovine cloning procedures during the three time periods demonstrated the impact of the technical skills and competence on the overall efficiency of in vitro embryo production by SCNT, and subsequent in vivo development.

Key-words: $\quad$ Bovine. In Vitro Embryo Production. Cell Culture. Cloning. Abnormal Offspring Syndrome. 


\section{LISTA DE FIGURAS}

Figura 3.1 - Diagrama esquemático ilustrando o desenvolvimento típico das membranas extra-embrionárias em mamíferos

Figura 3.2 - Mudanças aproximadas no peso do feto, fluidos intra-uterinos, útero e das membranas fetais durante a gestação de bovinos.

Figura 3.3 - Mudanças relativas aproximadas no peso do feto, fluidos intra-uterinos, útero e das membranas fetais durante a gestação de bovinos

Figura 4.1 - Taxas de blastocisto (\%) para embriões clonados, independente do esquema de agregação, reconstruídos com utilização de células com Baixa (70 - 80\%), Média (80-90\%) ou Alta (>95\%) confluência em cultivo. ${ }^{\mathrm{a}-\mathrm{x}}$ Colunas com sobrescritos desiguais diferem, $\mathrm{P}<0,05$

Figura 5.1 - Ilustração da produção e formação dos grupos experimentais de embriões clones utilizando a técnica do HMC e do sistema WOW de cultivo in vitro de embriões.

Figura 5.2 - Ilustração da produção e formação dos grupos experimentais de embriões partenotos utilizando a técnica do HMC e do sistema WOW de cultivo in vitro de embriões.

Figura 5.3 - Taxas de clivagem (\%) para embriões clones e partenotos bovinos reconstruídos por agregação, com distintos volumes citoplasmáticos e intervalos de fusão-ativação. ${ }^{\text {a-e: }}$ Colunas com sobrescritos desiguais diferem, $\mathrm{P}<0,05$

Figura 5.4 - Taxas de blastocisto (\%) para embriões clones e partenotos bovinos reconstruídos por agregação, com distintos volumes citoplasmáticos e intervalos de fusão-ativação. ${ }^{\text {a-f: }}$ Colunas com sobrescritos desiguais diferem, $\mathrm{P}<0,05 .$.

Figura 5.5 - Taxas de clivagem e blastocisto baseadas nos embriões cultivados, e de blastocisto baseada nos clivados (\%) para embriões clones, ativados com intervalos de fusão-ativação de 2 (2 hpf) ou 4 (4 hpf) horas, independente do esquema de agregação. ${ }^{\mathrm{a}-\mathrm{b}:}$ Dentro de cada taxa, colunas com sobrescritos desiguais diferem, $\mathrm{P}<0,05$. 
Figura 5.6 - Taxas de clivagem e blastocisto baseadas nos embriões cultivados, e de blastocisto baseada nos clivados (\%) para embriões clones, agregados ( $2 \mathrm{x}$ $100 \%)$ ou não (1 x 100\%), independente do intervalo de fusão-ativação. ${ }^{a-b:}$ Dentro de cada taxa, colunas com sobrescritos desiguais diferem, $\mathrm{P}<0,05 \ldots . . . .66$

Figura 5.7 - Taxas de prenhez e manutenção da gestação até o dia 225 (\%) para embriões bovinos clonados submetidos a dois intervalos de fusão-ativação (2 hpf vs. 4 hpf) e dois esquemas de cultivo in vitro ( 1 x 100\% vs. 2 x 100\%).

Figura 5.8 - Taxas de perdas gestacionais (\%) para embriões bovinos clonados submetidos a dois intervalos de fusão-ativação ( 2 hpf vs. 4 hpf) e dois esquemas de cultivo in vitro (1 x 100\% vs. 2 x 100\%) até o dia 225 de gestação..

Figura 6.1 - Protocolo utilizado para sincronização do estro das fêmeas receptoras de embriões...

Figura 6.2 - Sonogramas de um dos animais do grupo TNCS aos 51 dias de gestação. (A) Vista sagital do concepto; (B) Placentônio próximo ao feto.

Figura 6.3 - Esquema utilizado para classificação dos placentônios segundo a morfologia individual.

Figura 6.4 - Freqüência de aparecimento dos tipos de placentônio, independente do corno gestante, entre os três grupos (Controle, FIV e TNCS) aos $225 \pm 2$ dias de gestação. ${ }^{\mathrm{a}-\mathrm{b}}$ Dentro de cada tipo, colunas com sobrescritos desiguais diferem, $\mathrm{P}<0,05$

Figura 6.5 - Comprimento, largura e peso médio dos placentônios, independente do corno gestacional, nos grupos Controle, FIV e TNCS aos $225 \pm 2$ dias de gestação (l.s.m. \pm s.e.m.). ${ }^{\text {a-b: }}$ Dentro de cada medida, colunas com sobrescritos desiguais diferem, $\mathrm{P}<0,05$

Figura 6.6 - Freqüência (n) do comprimento médio (cm) apresentado por todos os placentônios de ambos os cornos uterinos, dos grupos Controle, FIV e TNCS aos $225 \pm 2$ dias de gestação

Figura 6.7 - Comprimento (A), largura (B) e peso (C) médio dos placentônios nos cornos uterinos prenhe e não-prenhe nos grupos experimentais (Controle, FIV e TNCS) aos $225 \pm 2$ dias de gestação (l.s.m. \pm s.e.m.). ${ }^{\text {a-d: }}$ Colunas com sobrescritos desiguais diferem, $\mathrm{P}<0,05$ 
Figura 6.8 - Comprimento (A), largura (B) e peso (C) médio dos placentônios por tipo de placentônio, nos grupos experimentais (Controle, FIV e TNCS) aos $225 \pm 2$

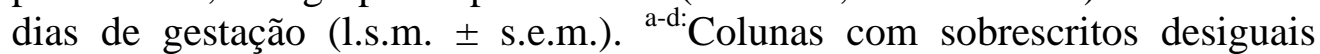
diferem, $\mathrm{P}<0,05$

Figura 6.9 - Concentração (mg/dL) de glicose (A) e frutose (B) nos plasmas materno e fetais, e fluidos fetais de fêmeas prenhes de fetos dos grupos Controle, FIV e TNCS aos $225 \pm 2$ dias de gestação (l.s.m. \pm s.e.m.).

Figura 6.10 - Diferença veno-arterial (V-A) de concentração (mg/dL) de glicose e frutose entre os plasmas da veia e artéria fetais de fêmeas prenhes de fetos dos grupos Controle, FIV e TNCS aos $225 \pm 2$ dias de gestação (l.s.m. \pm s.e.m.). ${ }^{\mathrm{a}-}$ b:Dentro de cada carboidrato, colunas com sobrescritos desiguais diferem, $\mathrm{P}<0,05$

Figura 6.11 - Quantidade total (g) de glicose (A), frutose (B) e de glicose+frutose (C) nos fluidos fetais de fêmeas prenhes de fetos dos grupos Controle, FIV e TNCS aos $225 \pm 2$ dias de gestação (l.s.m. \pm s.e.m.). ${ }^{\text {a-b: }}$ Dentro de cada fluido, colunas com sobrescritos desiguais diferem, $\mathrm{P}<0,05$

Figura 7.1 - Ilustração das principais etapas do procedimento de clonagem por transferência nuclear de célula somática utilizando a técnica do Handmade Cloning

Figura 7.2 - Distribuição do estádio (Estádio 5: blastocisto inicial; Estádio 6: blastocisto; Estádio 7: blastocisto expandido; Estádios 8/9: blastocistos em eclosão ou eclodidos) dos embriões clones produzidos nos três períodos experimentais compilados. ${ }^{\mathrm{a} e \mathrm{e}}$ Colunas com sobrescritos desiguais diferem, $\mathrm{p}<0,05$

Figura 7.3 - Distribuição da qualidade (Grau 1, ótima; Grau 2, boa; Grau 3, ruim) dos embriões clones produzidos nos três períodos experimentais compilados. ${ }^{\text {a-d: }}$ Colunas com sobrescritos desiguais diferem, $\mathrm{p}<0,05$

Figura 7.4 - Distribuição da qualidade (Grau 1: ótima, Grau 2: boa, Grau 3, ruim) dos embriões clones transferidos nos três períodos experimentais compilados. ${ }^{\text {a-e: }}$ Colunas com sobrescritos desiguais diferem, $\mathrm{p}<0,05$

Figura 7.5 - Fêmea bovina Nelore (“Catarina”) produzida por transferência nuclear pela metodologia do Handmade Cloning com 24 h (esquerda) e 1 ano (direita) de vida 


\section{LISTA DE TABELAS}

Tabela 4.1 - Desenvolvimento in vitro de embriões bovinos clonados produzidos por transferência nuclear de células somáticas oriundas de cultivos de distintas confluências e de cultivos in vitro de embriões com diferentes esquemas de agregação, Laboratório de Reprodução Animal, UDESC - Lages, SC - 2007 ...50

Tabela 5.1 - Taxas de clivagem e blastocisto e eficiência relativa de produção embrionária para totais de CCOs iniciais e para embriões clones e partenotos reconstruídos por agregação com distintos volumes citoplasmáticos e intervalos de fusão-ativação, Laboratório de Reprodução Animal, UDESC Lages, SC - 2008-2009.

Tabela 5.2 - Distribuição da freqüência relativa quanto a estádio e qualidade para embriões clones produzidos com distintos intervalos de fusão-ativação (2 hpf ou 4 hpf) e esquemas de agregação ( 1 x 100\% ou 2 x 100\%), Laboratório de Reprodução Animal, UDESC - Lages, SC - 2008-2009

Tabela 5.3 - Taxas de prenhez após a transferência de embriões bovinos clonados com intervalos fusão-ativação de 2 ou 4 h pós-fusão (hpf) e cultivados in vitro individualmente (1 x 100\%) ou agregados ( 2 x 100\%), EPAGRI - Lages, SC 2008-2009.

Tabela 6.1 - Resultados de 20 rotinas de produção in vitro de embriões por transferência nuclear de célula somática (TNCS), incluindo a eficiência por etapa obtida e a média por rotina de estruturas trabalhadas e/ou produzidas em cada etapa, Laboratório de Reprodução Animal, UDESC - Lages, SC - 2008-2009

Tabela 6.2 - Taxas de prenhez e de perdas gestacionais ao longo da gestação no grupo TNCS com um ou dois embriões transferidos por receptora - Santa Catarina 2007-2009.

Tabela 6.3 - Taxas de prenhez e de perdas gestacionais ao longo da gestação nos grupos Controle, FIV e TNCS - Santa Catarina - 2007-2009.

Tabela 6.4 - Resultados das mensurações dos conceptos dos grupos Controle, FIV e TNCS por ultrasonografia aos 51 dias de gestação (l.s.m. \pm s.e.m.) - Santa Catarina 2008-2009. 
Tabela 6.5 - Pesos, medidas lineares e volumes de úteros gravídicos de conceptos dos grupos Controle, FIV e TNCS aos $225 \pm 2$ dias de gestação (l.s.m. \pm s.e.m.) Santa Catarina - 2008-2009.

Tabela 6.6 - Pesos e medidas lineares de fetos dos grupos Controle, FIV e TNCS aos 225 \pm 2 dias de gestação (l.s.m. \pm s.e.m.) - Santa Catarina - 2008-2009

Tabela 6.7 - Pesos e medidas lineares de tecidos, órgãos e glândulas de fetos dos grupos Controle, FIV e TNCS aos $225 \pm 2$ dias de gestação (l.s.m. \pm s.e.m.) - Santa Catarina - 2008-2009.

Tabela 6.8 - Particularidades morfo-patológicas macroscópicas de conceptos do grupo TNCS aos 225 dias de gestação - Santa Catarina - 2008-2009.

Tabela 6.9 - Resultados das mensurações da osmolalidade (mOsm/Kg) dos plasmas maternos e fetais, e fluidos fetais de fêmeas prenhes de fetos dos grupos Controle, FIV e TNCS aos $225 \pm 2$ dias de gestação (l.s.m. \pm s.e.m.) - Santa Catarina - 2008-2009

Tabela 7.1 - Taxas de fusão, clivagem e blastocisto para hemi-embriões agregados (G1, 2 x 50\%) e embriões (G2, 1 x 100\%) clones bovinos produzidos por TNCS, e para partenotos nos três períodos experimentais (P1, P2 e P3), entre os meses de janeiro de 2007 e maio de 2009, Laboratório de Reprodução Animal, UDESC - Lages, SC - 2007-2009

Tabela 7.2 - Taxas de fusão, clivagem e blastocisto para hemi-embriões agregados (G1, 2 x 50\%) e embriões (G2, 1 x 100\%) clones bovinos produzidos por TNCS submetidos ou não à re-fusão nos dois primeiros períodos experimentais (P1, P2), entre os meses de janeiro de 2007 e julho de 2008, Laboratório de Reprodução Animal, UDESC - Lages, SC - 2007-2008

Tabela 7.3 - Distribuição da freqüência relativa quanto a estádio e qualidade para embriões clones, e da eficiência relativa de desenvolvimento embrionário por total de oócitos, independente da reconstrução empregada nos três períodos experimentais (P1, P2 e P3), entre os meses de janeiro de 2007 e maio de 2009, Laboratório de Reprodução Animal, UDESC - Lages, SC - 2007-2009.141

Tabela 7.4 - Taxas de prenhez de embriões clones bovinos produzidos por TNCS, evolução de perdas gestacionais até o terceiro trimestre de gestação e eficiência relativa quanto ao número de CCOs iniciais nos três períodos apresentados, entre os meses de janeiro de 2007 e maio de 2009, Laboratório de Reprodução Animal, UDESC - Lages, SC - 2007-2009 
REVISÃO DE LITERATURA

ALTERAÇÕES EM CONCEPTOS DECORRENTES DA PRODUÇÃO IN VITRO DE EMBRIÕES ..

CAPÍTULO 1 DESENVOLVIMENTO IN VITRO DE EMBRIÕES BOVINOS CLONADOS PRODUZIDOS POR HANDMADE CLONING (HMC) PROVENIENTES DE DISTINTOS GENÓTIPOS E DE CULTIVOS CELULARES COM DIFERENTES CONFLUÊNCIAS ........ 42

CAPÍTULO 2 EFEITO DO INTERVALO FUSÃO-ATIVAÇÃO E DA AGREGAÇÃO EMBRIONÁRIA NO DESENVOLVIMENTO IN VITRO E IN VIVO DE EMBRIÕES BOVINOS CLONADOS PRODUZIDOS POR HANDMADE CLONING ........................................... 54

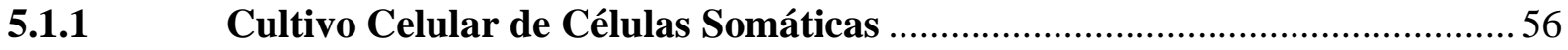

5.1.2 Produção In Vitro de Embriões por Transferência Nuclear de Célula Somática e por Partenogênese...

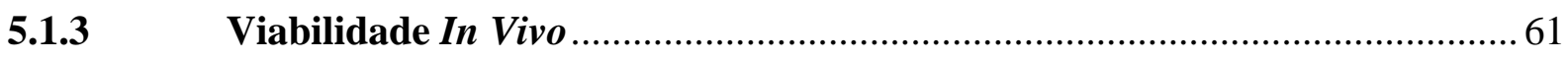

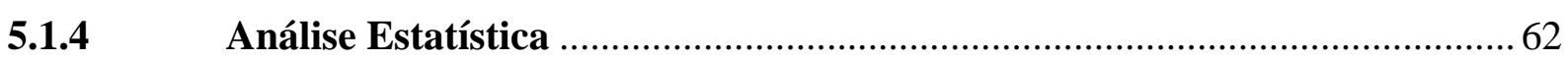


CAPÍTULO 3 COMPARAÇÃO MORFOLÓGICA, MORFOMÉTRICA E FISIOLÓGICA DE CONCEPTOS BOVINOS PRODUZIDOS IN VIVO, IN VITRO POR FECUNDAÇÃO E IN VITRO POR TRANSFERÊNCIA NUCLEAR.

MATERIAL E MÉTODOS ....................................................................... 81

6.1.1 Cultivo Celular de Células Somáticas ........................................................... 81

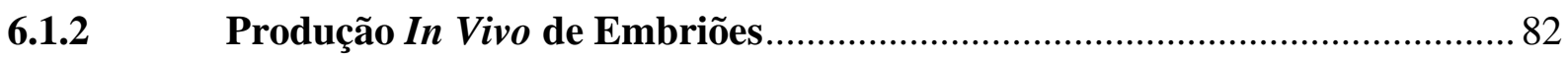

6.1.3 Produção In Vitro de Embriões por Fecundação In Vitro ............................. 83

6.1.4 Produção In Vitro de Embriões por Transferência Nuclear de Célula Somática e por Partenogênese...................................................................... 85

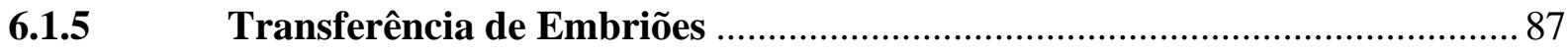

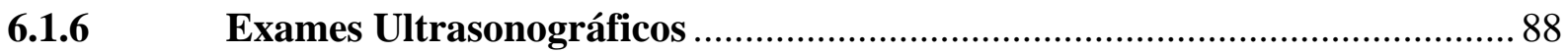

6.1.7 Coleta de Sangue, Fluidos e Tecidos Maternos e Fetais aos 225 Dias de

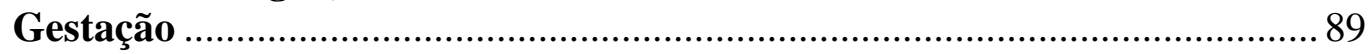

6.1.7.1 Processamento do Sangue Materno e Fetal e dos Fluidos Fetais após o Abate.. 91

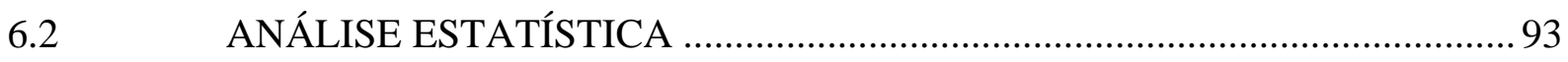

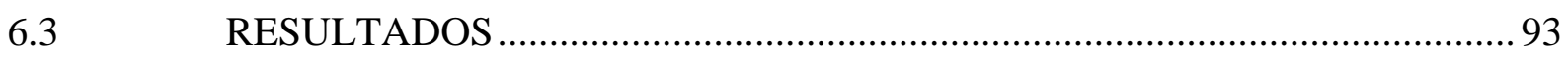

6.3.1 Produção de Embriões, Diagnóstico de Gestação e do Gênero Fetal ...........94

6.3.2 Morfometria e Morfologia de Conceptos Bovinos aos 51 Dias de Gestação 96

6.3.3 Morfometria e Morfologia de Conceptos Bovinos aos 225 Dias de

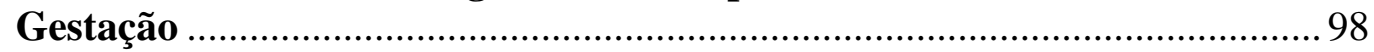

6.3.3.1 Características do Trato Reprodutivo Grávido e seus Componentes aos 225

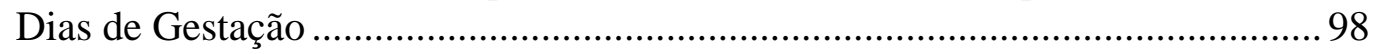

6.3.3.2 Características Fetais dos Conceptos aos 225 Dias de Gestação ....................... 100

6.3.3.3 Características Placentárias dos Conceptos aos 225 Dias de Gestação ............. 103

6.3.3.4 Particularidades Morfo-Patológicas Macroscópicas de Conceptos do Grupo TNCS aos 225 Dias de Gestação.................................................................... 108

6.3.4 Mensurações de Carboidratos no Plasma Materno e Fetal e nos Fluidos Fetais de Conceptos aos 225 Dias de Gestação ......................................... 110

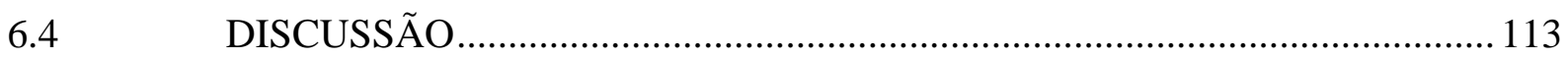

CAPÍTULO 4 ANÁLISE RETROSPECTIVA DA EVOLUÇÃO TÉCNICA E EFICIÊNCIA DO PROCESSO DE CLONAGEM POR HANDMADE CLONING EM BOVINOS ............................................. 127

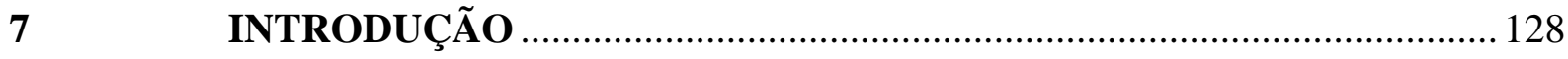

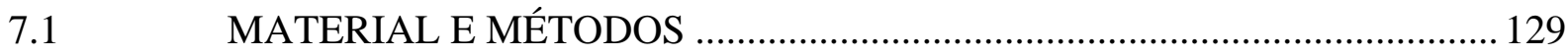


7.1.2 Cultivo Celular de Células Somáticas …................................................. 130

7.1.3 Produção In Vitro de Embriões por Transferência Nuclear de Célula Somática e por Partenogênese................................................................ 131

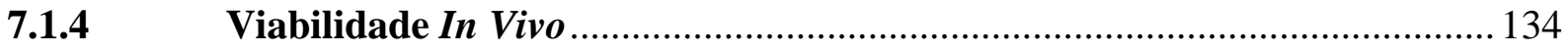

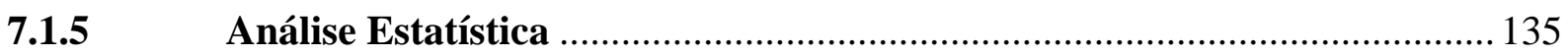

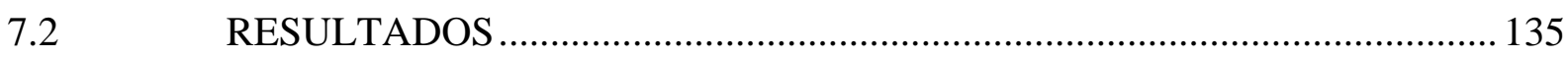

DISCUSSÃO

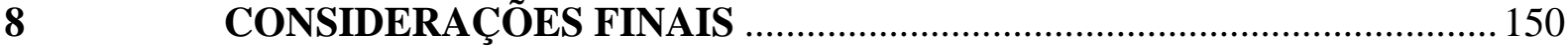

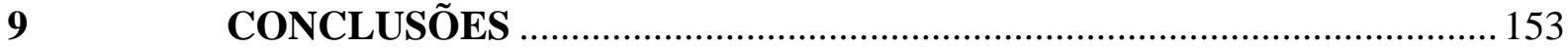

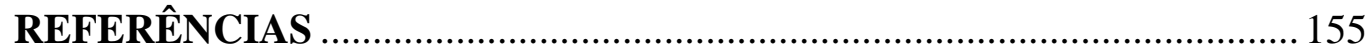

ANEXO A - Procedimentos Cirúrgicos de Canulação Cordonal e Infusão de Substratos Marcados, Seguido de Coleta de Amostras Sanguíneas .............................................................................. 169 


\section{INTRODUÇÃO}

O Brasil possui o maior rebanho bovino comercial do mundo, com aproximadamente 173 milhões de cabeças espalhadas pelo território nacional (ANUALPEC, 2009). Oitenta por cento destes animais (137 milhões) destinam-se à pecuária de corte. A bovinocultura de corte representa a maior fatia do agronegócio brasileiro, gerando faturamento de mais de $\mathrm{R} \$ 50$ bilhões/ano e oferecendo cerca de 7,5 milhões de empregos diretos e indiretos (ABIEC, [200_]). O sistema de produção na pecuária brasileira caracteriza-se por ser de baixo custo e em sua grande maioria, extensivo. A expectativa para as próximas décadas é de crescimento, tanto no consumo quanto no comércio mundial de produtos de origem animal, devido à melhora da renda per capita e da qualidade de vida de diversos países emergentes, como o Brasil.

Visto que a expansão das fronteiras agrícolas da região Centro-Oeste e Norte do país tendem a estagnar pela preocupação crescente com o meio ambiente por parte da sociedade, há a necessidade de uma intensificação no sistema de produção, com o aumento da produção e da qualidade de carne e leite por hectare, visando atender a expansão do consumo destes produtos brasileiros no cenário nacional e internacional. Esta intensificação deve abranger todas as esferas que compõem o sistema de produção, incluindo a reprodução. Desta forma, a utilização de biotécnicas da reprodução na bovinocultura é de grande importância para a padronização dos rebanhos, elevação das taxas de concepção e nascimento, e para acelerar a seleção e multiplicação de animais com características de interesse.

Nas últimas décadas, o emprego da inseminação artificial e da múltipla ovulação de fêmeas bovinas associada à transferência de embriões demonstrou a importância da aplicação destas técnicas na multiplicação de animais de interesse zootécnico e comercial. Mais recentemente, novas biotecnologias foram incorporadas à área da reprodução, como a produção de embriões in vitro por fecundação in vitro (FIV), inicialmente realizada com oócitos maturados in vivo e com o cultivo embrionário inicial também in vivo (BRACKETT et al., 1982), mas posteriormente, com todas as etapas de produção de embriões completamente in vitro, incluindo a maturação (MIV), fecundação (FIV) e cultivo (CIV) in vitro (LU et al., 1988); e por último, representando um significativo avanço nesta área, a PIV de embriões por transferência nuclear (TN), descrita pela primeira vez em mamíferos (ovino) há vinte e quatro anos (WILLADSEN, 1986), com a utilização de blastômeros de embriões em estádios inicias de desenvolvimento, e efetivada com sucesso empregando células 
somáticas de um indivíduo adulto, dez anos após, com o nascimento da ovelha Dolly em julho de 1996 (WILMUT et al., 1997). Este último evento, por sinal, representou a queda de um importante dogma biológico, o de que células somáticas diferenciadas não poderiam ser reprogramadas a um estado toti- ou pluripotente que permitisse o desenvolvimento de um novo indivíduo. Subseqüentemente, a aplicação da clonagem de adultos por TN com células somáticas (TNCS) foi confirmada em várias espécies mamíferas (KATO et al., 1998; WAKAYAMA et al., 1998; BAGUISI et al., 1999; POLEJAEVA et al., 2000; CHESNÉ et al., 2002; SHIN et al., 2002; GALLI et al., 2003; WOODS et al., 2003; ZHOU et al., 2003; LEE et al., 2005; LI et al., 2006; KIM et al., 2007), de animais em risco de extinção (LANZA et al., 2000; LOI et al., 2001) e mesmo em espécies aquáticas (LEE et al., 2002; SUN et al., 2005), conforme revisado por Bertolini et al. (2007). Recentemente, o dromedário (Camelus dromedarius - publicado na mídia em 04/2009) e o búfalo (Bubalus bubalis - publicado na mídia em 06/2009) também entraram na lista de animais clonados.

Hoje, a produção in vitro (PIV) de embriões por FIV ou TNCS representa uma poderosa ferramenta que tem sido utilizada rotineiramente tanto em nível científico quanto comercial em várias regiões do mundo, fornecendo base técnica para estudos com célulastronco, terapia celular e medicina regenerativa, abrindo a possibilidade para a chamada 'clonagem terapêutica', propiciando ainda um significativo ganho nas bases de conhecimento da embriologia, biologia molecular, celular e do desenvolvimento, assim como em estudos fisiológicos, comportamentais e clínicos nas fases pré- e pós-natais, com impacto na saúde e bem estar animal. A clonagem possibilitou também a multiplicação de animais de interesse zootécnico, na preservação de espécies em risco de extinção e na produção de animais transgênicos, através da clonagem reprodutiva.

Não obstante a tantas possibilidades comerciais e científicas, com o desenvolvimento dos sistemas de PIV de embriões por FIV ou TN em várias espécies animais, em especial em bovinos, anormalidades de desenvolvimento tanto pré- quanto pós-natais apresentaram-se como conseqüências inesperadas e imprevisíveis destas manipulações embrionárias iniciais (WILLADSEN et al., 1991; BEHBOODI et al., 1995; FARIN; FARIN, 1995; WILSON et al., 1995; WALKER; HARTWICH; SEAMARK, 1996). Tais perturbações foram coletivamente denominadas como uma síndrome por Young, Sinclair e Wilmut (1998), nomeando-a "Large Offspring Syndrome" ou síndrome dos neonatos gigantes, conjecturando o aumento de peso dos neonatos como uma conseqüência às manipulações embrionárias iniciais. Todavia, esta denominação, apesar de ser a mais empregada atualmente, apresenta-se incompleta e parcial, visto que se restringe a alterações apenas em bovinos e ovinos e enfoca o tamanho do neonato 
como principal perturbação. Farin, Piedrahita e Farin (2006) sugeriram a mudança desta denominação para "Abnormal Offspring Syndrome" (AOS) ou síndorme dos neonatos anormais, devido ao conjunto maior de alterações descobertos ou associados a esta síndrome, em todas as fases da gestação, e em um maior número de espécies. Esta denominação é a que será empregada neste documento.

A ocorrência da AOS parece estar intrinsecamente associada ao concepto e não a disfunções maternas, conforme inicialmente observado por Young, Sinclair e Wilmut (1998). Os graus de alterações de desenvolvimento podem variar entre embriões no mesmo cultivo, entre protocolos de FIV e TN, ou mesmo entre laboratórios (KRUIP; DEN DAAS, 1997; WRENZYCKI et al., 1998, 1999, 2001; FARIN; CROSIER; FARIN, 2001; YOUNG et al., 2001). Nem todos os produtos, incluindo gêmeos idênticos produzidos por TN, apresentam sintomas da síndrome, o que demonstra o caráter epigenético e/ou ambiental, e não genético, deste fenômeno. Sabe-se que as condições de cultivo in vitro de embriões em presença de soro e/ou em co-cultivo em monocamadas de células de suporte (DEAN et al., 1998; WRENZYCKI et al., 1998, 1999; NIEMANN; WRENZYCKI, 2000; BERTOLINI et al., 2002a) e a falha de reprogramação epigenética inerente à técnica de TN (BOURC'HIS et al., 2001; KANG et al., 2001; XUE et al., 2002) estão diretamente relacionados ao aparecimento dos sintomas da AOS, dos quais os mais óbvios incluem o nascimento de bezerros com peso excessivo e com reduzida sobrevivência pós-natal. Um relativo baixo número de embriões clonados sobrevivem a termo ( 1 a $5 \%$ ), os quais freqüentemente necessitam atendimento clínico intensivo após o parto (HILL; CHAVATTE-PALMER, 2002). A alta mortalidade neonatal, os problemas clínicos no período periparto e uma tendência a uma menor sobrevida pós-natal em clones por TNCS são problemas comuns já descritos por muitos grupos (RENARD et al., 1999; HILL et al., 1999, 2000; KATO; TANI; TSUNODA, 2000).

As causas, conseqüências, incidência e perdas econômicas associadas à AOS são hoje consideradas mais importantes do que inicialmente reconhecidas. O prejuízo econômico causado pela AOS está relacionado às elevadas perdas embrionárias e fetais, mais comumente observadas entre os dias 30 e 60 de gestação (HILL et al., 2000; DE SOUZA et al., 2001; BERTOLINI; ANDERSON, 2002), e às anormalidades fetais e placentárias que culminam em distocias e o nascimento de bezerros com excesso de peso e reduzida sobrevivência pós-parto (BEHBOODI et al., 1995; WILSON et al., 1995; GARRY et al., 1996; WALKER; HARTWICH; SEAMARK, 1996; HILL et al., 1999, 2000; RENARD et al., 1999; KATO; TANI; TSUNODA, 2000; WELLS et al., 2004). Coletivamente, os problemas associados à AOS têm se tornado gradativamente importantes também sob o ponto de vista ético em 
termos do bem-estar animal, comprometendo a aplicabilidade comercial e científica destas tecnologias (BERTOLINI et al., 2007).

Sendo assim, a compreensão dos mecanismos que conduzem a esta síndrome propiciará o desenvolvimento de embriões in vitro, incluindo a elaboração de novos protocolos ou procedimentos, que se assemelhem aos produzidos in vivo, com implicações diretas nas biotecnologias da reprodução animal e da pecuária nacional. Ademais, a identificação de métodos ou características presentes no início da gestação que consigam predizer a ocorrência e a intensidade das alterações envolvidas em seu final, será de grande valia para o acompanhamento clínico dos animais produzidos, aumentando as chances de sobrevivência pré- e pós-natal e incrementando a eficiência e a taxa de sucesso da produção in vitro de embriões. 


\section{OBJETIVOS}

Este estudo faz parte de um projeto temático maior que visa obter informações científicas para a compreensão dos mecanismos de alteração morfológica e fisiológica que ocorrem nas fases pré- e pós-natal causadas por manipulações embrionárias in vitro (FIV e TNCS). A grande hipótese deste trabalho é de que o desenvolvimento anormal do concepto após a manipulação in vitro de embriões por FIV e TNCS é uma conseqüência de alterações na formação da placenta que promovem uma elevada mortalidade no terço inicial da gestação, e uma perda da capacidade de regulação da restrição placentária ao crescimento fetal no final da gestação, culminando com crescimento pré-natal acelerado, perdas gestacionais por insuficiência placentária e menor sobrevivência pré- e pós-natal.

Esta tese foi dividida em Capítulos, buscando-se avaliar os efeitos de algumas váriáveis biológicas e técnicas na produção de embriões in vitro por TNCS, e de comparar o desenvolvimento de prenhezes estabelecidas com embriões produzidos in vivo, in vitro por fecundação e in vitro por transferência nuclear, pela avaliação de dados morfométricos, morfológicos e bioquímicos coletados em distintos momentos da gestação.

No Capítulo 1 (Desenvolvimento in vitro de embriões bovinos clonados produzidos por handmade cloning provenientes de distintos genótipos e de cultivos celulares com diferentes confluências), o desenvolvimento in vitro de embriões clonados foi comparado entre células somáticas de dois cultivos celulares diferentes, e entre três intervalos de confluência celular do mesmo cultivo. Parâmetros como taxas de clivagem e blastocisto foram utilizados para comparar este desenvolvimento in vitro. Os objetivos específicos deste experimento foram:

(a) Comparar o efeito da utilização de células de animais geneticamente distantes na produção in vitro de embriões clonados; e

(b) Comparar o efeito da utilização de células de um mesmo animal, em diferentes fases do ciclo celular no momento da transferência nuclear, no desenvolvimento in vitro embrionário posterior.

No Capítulo 2 (Efeito do intervalo fusão-ativação e da agregação embrionária no desenvolvimento in vitro e in vivo de embriões bovinos clonados produzidos por handmade cloning), comparou-se o efeito de dois intervalos de fusão-ativação e da agregação ou não de embriões no momento do cultivo, no desenvolvimento in vitro destes embriões clonados, 
seguido da transferência para fêmeas receptoras síncronas no dia 7, visando avaliar o desenvolvimento in vivo posterior. Os objetivos específicos deste experimento foram:

(a) Avaliar o efeito de dois intervalos de fusão-ativação na reprogramação nuclear e reinício do ciclo celular, comparando o desenvolvimento in vitro e in vivo de embriões clonados; e

(b) Avaliar o efeito da agregação de embriões no momento do cultivo, como um fator aditivo benéfico no desenvolvimento in vitro e in vivo de embriões clonados.

No Capítulo 3 (Comparação morfológica, morfométrica e fisiológica de conceptos bovinos produzidos in vivo, in vitro por fecundação e in vitro por transferência nuclear), prenhezes estabelecidas com embriões produzidos in vivo, in vitro por fecundação e in vitro por transferência nuclear foram comparadas pela avaliação de dados morfométricos e bioquímicos coletados em distintos momentos da gestação. Os objetivos específicos deste experimento foram:

(a) Comparar as taxas de prenhez aos 30 dias de gestação e de perdas gestacionais subseqüentes que ocorreram até os 225 dias;

(b) Comparar os dados morfométricos e morfológicos de conceptos aos 51 dias de gestação, a partir de imagens coletadas por intermédio da ultrasonografia, e aos 225 dias de gestação, a partir da coleta de material após abate;

(c) Mensurar a concentração de glicose e de frutose nos compartimentos materno e fetal aos 225 dias de gestação; e

(d) Determinar as associações fisiológicas entre os dados morfológicos e morfométricos coletados aos 51 e 225 dias e as concentrações de substratos no ambiente fetal aos 225 dias de gestação nos três grupos experimentais.

No Capítulo 4 (Análise retrospectiva da evolução técnica e eficiência do processo de clonagem por handmade cloning em bovinos), foram comparados os resultados de produção de embriões clonados e do estabelecimento de prenhezes em nosso laboratório após vinte e oito meses, divididas em três períodos de atividades. Os objetivos específicos deste experimento foram:

(a) Comparar a evolução temporal dos resultados da clonagem por handmade cloning obtidos em nosso laboratório, em três períodos distintos de atividades a partir da implementação da metodologia; e

(b) Determinar os efeitos do aumento da experiência técnica sobre as taxas de produção de embriões e estabelecimento de prenhezes ao longo do tempo. 


\section{REVISÃO DE LITERATURA}

A revisão de literatura foi sistematizada em tópicos para melhor compreensão e abordagem do assunto, dividindo-se em: (a) formação da placenta bovina; (b) desenvolvimento placentário e fetal; (c) alterações em conceptos decorrentes da produção in vitro de embriões; e (d) comprometimento da restrição placentária ao crescimento fetal no terceiro trimestre da gestação.

\subsection{FORMAÇÃO DA PLACENTA BOVINA}

A placenta é formada em todas as regiões onde as membranas fetais se aderem à mucosa uterina, com o propósito de realizar trocas materno-fetais (PERRY, 1981; LEISER; KAUFMANN, 1994). Por definição, segundo Junqueira e Carneiro (2004), a placenta é um órgão transitório encontrado apenas em mamíferos (eutérios), formado pela justaposição das membranas fetais e tecidos maternos, sendo a estrutura intermediária das trocas fisiológicas entre mãe e feto durante toda a gestação. Promove a proteção contra insultos físicos e da entrada no ambiente fetal de diversos agentes infecciosos e/ou tóxicos (SLOSS; DUFTY, 1980). Além destas funções, a placenta atua como órgão endócrino sintetizando hormônios como a progesterona, estradiol, gonadotrofinas coriônicas, lactogênio placentário e glicoproteínas associadas à prenhez (SENGER et al., 2003).

O desenvolvimento placentário dos mamíferos domésticos ocorre antes da implantação do embrião no útero materno, iniciando-se com a diferenciação e formação das membranas extra-embrionárias que compõe a porção fetal da placenta (MOSSMAN, 1987). O estádio de blastocisto embrionário, com a formação da blastocele, uma cavidade central interna preenchida por fluido, propicia a formação de duas populações celulares distintas denominadas massa celular interna (MCI) e trofoblasto (SCHLAFER; FISHER; DAVIES, 2000). As células da MCI, alocadas a uma das regiões internas do blastocisto, formam o embrião propriamente dito e as membranas extra-embrionárias, com exceção do trofoblasto. As células trofoblásticas localizam-se próximas a zona pelúcida e revestem a blastocele, e formam posteriormente a camada mais externa do córion, um dos componentes fetais da placenta (SCHLAFER; FISHER; DAVIES, 2000). 
Com a eclosão da zona pelúcida, o desenvolvimento do embrião passa por uma nova fase de crescimento massivo e de diferenciação celular, onde os mamíferos de cada ordem (Artiodactyla, Perissodactyla, Rodentia, Carnivora, etc.) exibem grande diversidade tanto no modelo de desenvolvimento quanto na forma final das membranas e placenta (PERRY, 1981; GUILLOMOT; FLÉCHON; LEROY, 1993). Contudo, este desenvolvimento apresenta um eixo comum e invariavelmente culmina com a formação das quatro membranas extraembrionárias conhecidas: córion, alantóide, âmnio e saco vitelino (PERRY, 1981). Estas membranas extra-embrionárias são os componentes da porção fetal da placenta que dependendo da espécie e fase gestacional em questão, são responsáveis por uma maior ou menor participação na mesma (LEISER; KAUFMANN, 1994).

O desenvolvimento destas membranas foi sumarizado por Schlafer, Fisher e Davies, (2000) e Senger et al. (2003), e está ilustrado em um diagrama esquemático explicativo na figura 3.1.
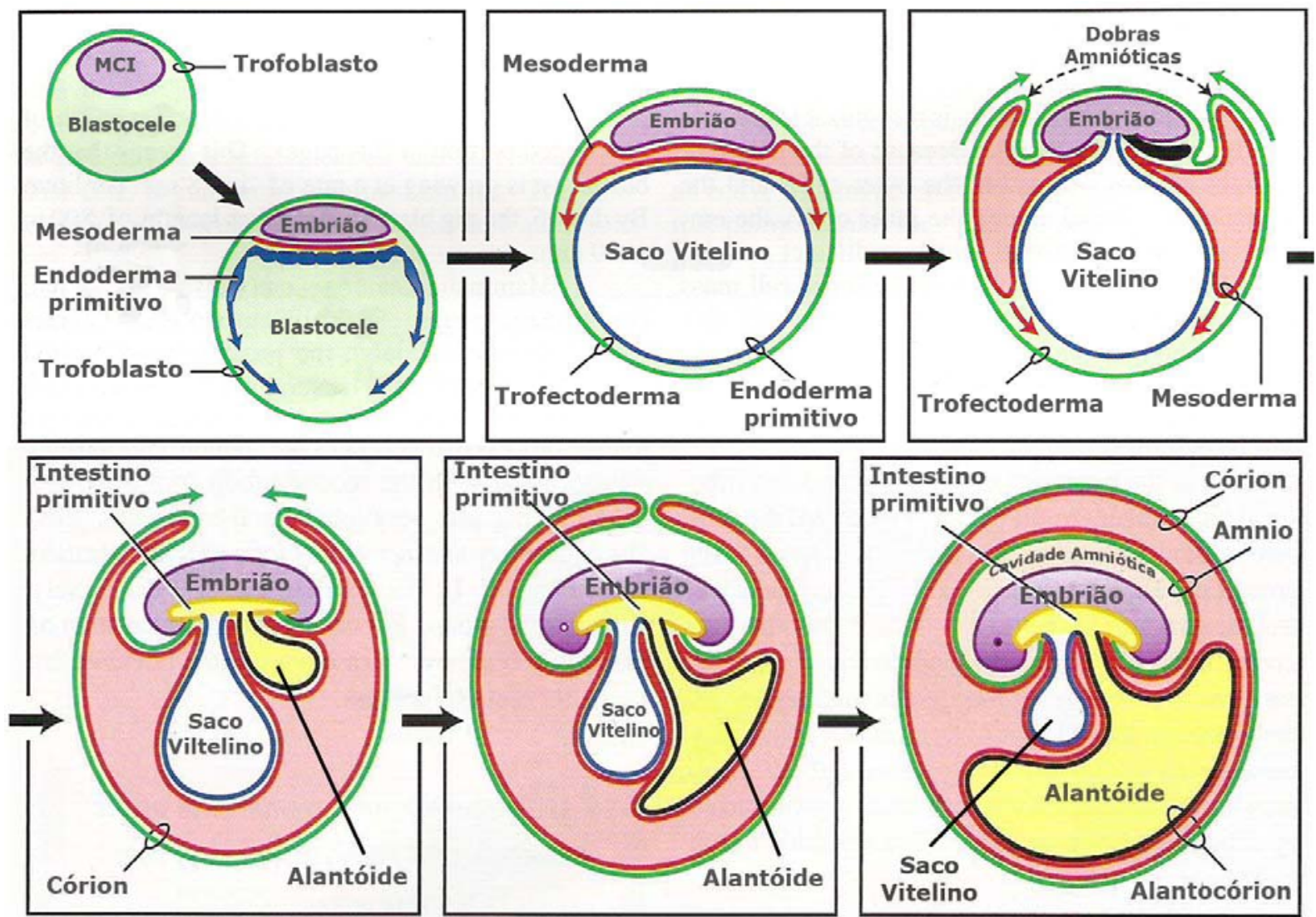

Fonte: (Modificado de SENGER et al., 2003)

Figura 3.1 - Diagrama esquemático ilustrando o desenvolvimento típico das membranas extra-embrionárias em mamíferos 
O embrião, após a eclosão e saída da zona pelúcida continua a crescer, de maneira preponderante pelo acúmulo de líquido na blastocele e pela reorganização celular. Uma camada de células ventral à MCI começa a se diferenciar e desenvolver, sendo denominada de endoderma primitivo. Este folheto migra ventralmente, delineado pelas células do trofoblasto mais externas, e termina por envolver a blastocele, formando o saco vitelino. Concomitante, o mesoderma começa a se desenvolver entre o endoderma e a $\mathrm{MCI}$ ou embrião propriamente dito. O âmnio se forma pela expansão do mesoderma dorsalmente e lateralmente ao embrião, culminando com a formação de uma nova cavidade repleta de fluido que envolve o mesmo (cavidade amniótica). Esta mesma expansão promove a fusão do mesoderma e do trofectoderma, originando o córion. Concomitante a regressão continua do saco vitelino, uma evaginação da região posterior do intestino primitivo do embrião começa a se desenvolver e a migrar em direção ao mesoderma antes do fechamento da cavidade abdominal ventral do embrião. Esta estrutura saculiforme, denominada alantóide, cresce exponencialmente pelo acumulo de líquido e resíduo do metabolismo embrionário, e carreia consigo os vasos que irão promover a vascularização da porção fetal da placenta. Este crescimento do alantóide culmina com o contato do córion formando o corioalantóide, que na maioria dos mamíferos é a membrana dominante da placenta e a responsável pelo contato e implantação com o tecido materno (LEISER; KAUFMANN, 1994).

O processo de implantação em mamíferos é resultante de uma série de interações altamente coordenadas, as quais se iniciam mais especificamente em torno dos 18 dias de gestação em bovinos, com o contato íntimo entre a superfície das membranas do concepto e o epitélio uterino (GUILLOMOT; FLÉCHON; LEROY, 1993). Este período, além de compreender a organogênese embrionária per se, com a formação dos distintos tecidos, órgãos e sistemas do novo indivíduo, inclui também o estabelecimento da placenta definitiva, a qual persiste até o momento do parto (SLOSS; DUFTY, 1980). De acordo com Guillomot, Fléchon e Leroy (1993), a implantação em bovinos é um processo gradual e contínuo, dividido em três fases: $1^{\text {a }}$ - pré-contato ou adesão ( $\sim 17$ dias $)$ - período no qual o concepto se alonga consideravelmente, ocorrendo aproximação das membranas ao epitélio uterino; $2^{\mathrm{a}}-$ aposição ( 18-19 dias) - estabelecimento de um contato celular estável entre o tecido materno e fetal; $3^{\text {a }}$ - adesão ( 22-42 dias) - formação da estrutura tecidual da placenta.

Nos bovinos, a expansão do corioalantóide em direção às projeções do endométrio uterino (carúnculas) promove o remodelando desta camada. O remodelamento pode ser visualizado grosseiramente aos 30 dias de gestação como espessamentos irregulares, denominados cotilédones fetais, localizados em posição oposta às carúnculas maternas 
(SCHLAFER; FISHER; DAVIES, 2000). Esta progressão leva à formação de vilosidades semelhantes a dedos (papilas) que se interdigitam com os recessos ou criptas da superfície caruncular materna, bem definidas aos 33 dias (SLOSS; DUFTY, 1980). Uma união mais firme e íntima é estabelecida em sequência, quando uma invasão mais profunda nas criptas por parte das vilosidades ocorre, produzindo ramificações laterais (SLOSS; DUFTY, 1980). Aos 45 dias, as criptas e as vilosidades podem ser facilmente reconhecidas e distinguidas. A combinação do cotilédone fetal e da carúncula materna estabelece a unidade morfofuncional da placenta bovina, denominada placentoma (SCHLAFER; FISHER; DAVIES, 2000). Todavia, esta denominação aparece em desuso e deve ser evitada pela conotação de uma formação patológica que o sufixo "oma" de placentoma sugere. Sendo assim, segundo Miglino (1991), o termo preferencial empregado deve ser placentônio, cujo sufixo é característico de unidades morfofuncionais, amplamente utilizados em outros órgãos.

Segundo Leiser e Kaufmann (1994), a placenta pode ser classificada baseando-se em diversos critérios. A variabilidade da classificação compreende: o tipo e o número de membranas envolvidas; o padrão geométrico de interdigitação das superfícies maternas e fetais; o tipo e o número de tecidos separando o sangue materno e fetal; e o arranjo geométrico dos vasos. Por estes critérios, a placenta dos bovinos seria classificada em: corioalantóica, pela presença do córion unido ao alantóide na porção fetal; cotiledonária, pelas vilosidades coriônicas estarem restritas às carúnculas maternas; epiteliocorial, pela separação dos vasos permanecerem no nível do epitélio materno e córion fetal; e corrente sanguínea cruzada, pelos vasos maternos e fetais cruzarem em eixo perpendicular uns aos outros.

Por muitos anos, os pesquisadores acreditaram que as placentas cotiledonárias microscopicamente poderiam ser classificadas em sindesmocoriais ou sinepiteliocoriais, mas atualmente, é de comum acordo que estas placentas são classificadas primariamente em epiteliocoriais (GUILLOMOT; FLÉCHON; LEROY, 1993). Esta peculiaridade na classificação da placenta da Família Bovidae deve-se à presença de um grupo de células peculiares e particulares denominadas células trofoblásticas gigantes binucleadas, que representam aproximadamente $20 \%$ da população celular trofoblástica em ruminantes (WOODING; WATHES, 1980; WOODING, 1982). Estas células migram do epitélio trofoblástico e se fusionam com as células uterinas formando temporariamente células híbridas trinucleadas (WOODING, 1984). Este mecanismo é importante para que ocorra o transporte e liberação dos grânulos citoplasmáticos presentes nestas células no compartimento materno (SCHLAFER; FISHER; DAVIES, 2000). Os grânulos contêm hormônios como a progesterona, lactogênio placentário, glicoproteínas associadas à prenhez e ao crescimento 
fetal, que promovem o desenvolvimento e manutenção da prenhez (SCHLAFER; FISHER; DAVIES, 2000).

\subsection{DESENVOLVIMENTO PLACENTÁRIO E FETAL}

O desenvolvimento pré-natal é um processo contínuo que pode ser dividido em fase embrionária e fetal, baseado no padrão de crescimento e desenvolvimento do concepto (SLOSS; DUFTY, 1980). Na fase embrionária, ocorre intensa diferenciação celular até a completa organogênese e o estabelecimento definitivo da placenta. $\mathrm{Na}$ fase fetal, a partir dos 42 dias, o feto inicia a fase da gestação caracterizada por um marcante aumento de tamanho e peso, e por uma mudança na proporção relativa de diversas porções do corpo (ELEY et al., 1978; PRIOR; LASTER, 1979; FERRELL, 1989; REYNOLDS et al., 1990). Segundo Sloss e Dufty (1980), embora apenas pequenos incrementos no peso fetal ocorram no início desta fase, mais de $90 \%$ do peso final é adquirido na segunda metade da gestação, sendo a sua maioria, mais especificamente, no terço final (FERRELL, 1989), conforme ilustrado na figura 3.2 .

A placenta, por sua vez, cresce mais rapidamente que o feto no início, com o peso placentário sendo maior do que o fetal no primeiro terço da gestação (ELEY et al., 1978). Este período inicial de maior crescimento placentário é considerado importante para o estabelecimento da placenta, o que dará suporte ao crescimento fetal no segundo e terceiro trimestres da gestação (ELEY et al., 1978; PRIOR; LASTER, 1979; FERRELL, 1989; REYNOLDS et al., 1990). 


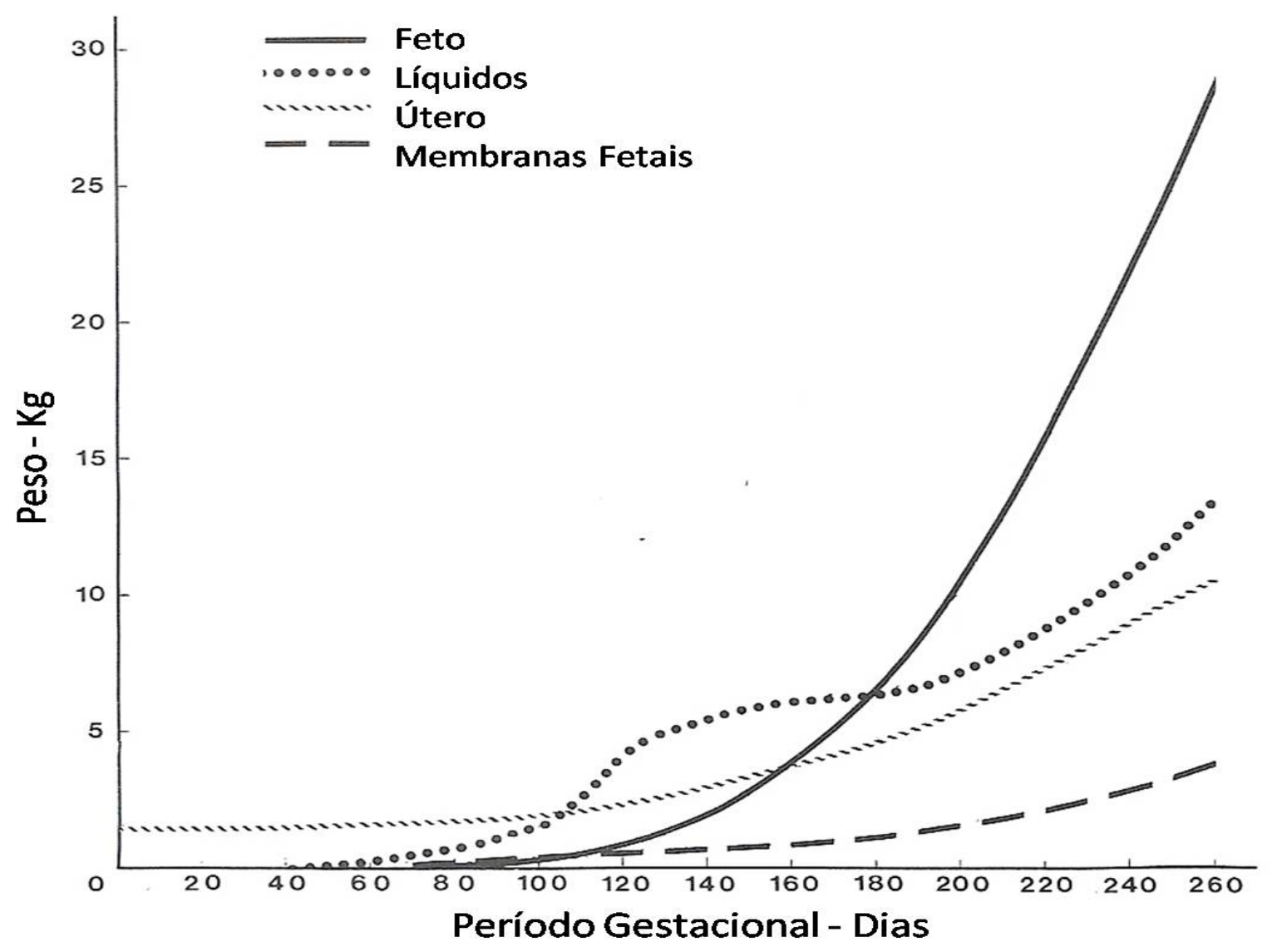

Fonte: (Modificado de SLOSS; DUFTY, 1980)

Figura 3.2 - Mudanças aproximadas no peso do feto, fluidos intra-uterinos, útero e das membranas fetais durante a gestação de bovinos

Sloss e Dufty (1980) elaboraram um gráfico do peso relativo de cada um dos componentes presentes durante a gestação de bovinos (feto, fluidos intra-uterinos, útero e membranas fetais) em relação ao peso total do útero gravídico, apresentado na figura 3.3. Observou-se o aumento significativo do peso fetal a partir da segunda metade gestacional (140 dias), com o feto apresentando $60 \%$ do peso total no início do terço final da prenhez. Esta proporção também foi observada por Ferrell, Garrett e Hinman (1976), mas apenas a partir dos 226 dias, com mais de 50\% do peso do trato uterino gravídico conferido ao peso fetal. Reynolds et al. (1990) verificaram o crescimento exponencial dos placentônios entre os 100 e 250 dias de gestação, com o crescimento relativo de 6\% no início. Este crescimento aumentado fica demonstrado no gráfico da figura 3.3, ao se observar o peso relativo das membranas fetais no terço inicial, que supera o peso fetal até os primeiros cem dias de gestação. O crescimento placentário relativo alcança o seu maior valor entre os dias 180 e 200 de gestação, precedendo o pico de crescimento fetal relativo aos 230 dias (ELEY et al., 1978; PRIOR; LASTER, 1979; FERRELL, 1989; REYNOLDS et al., 1990). 


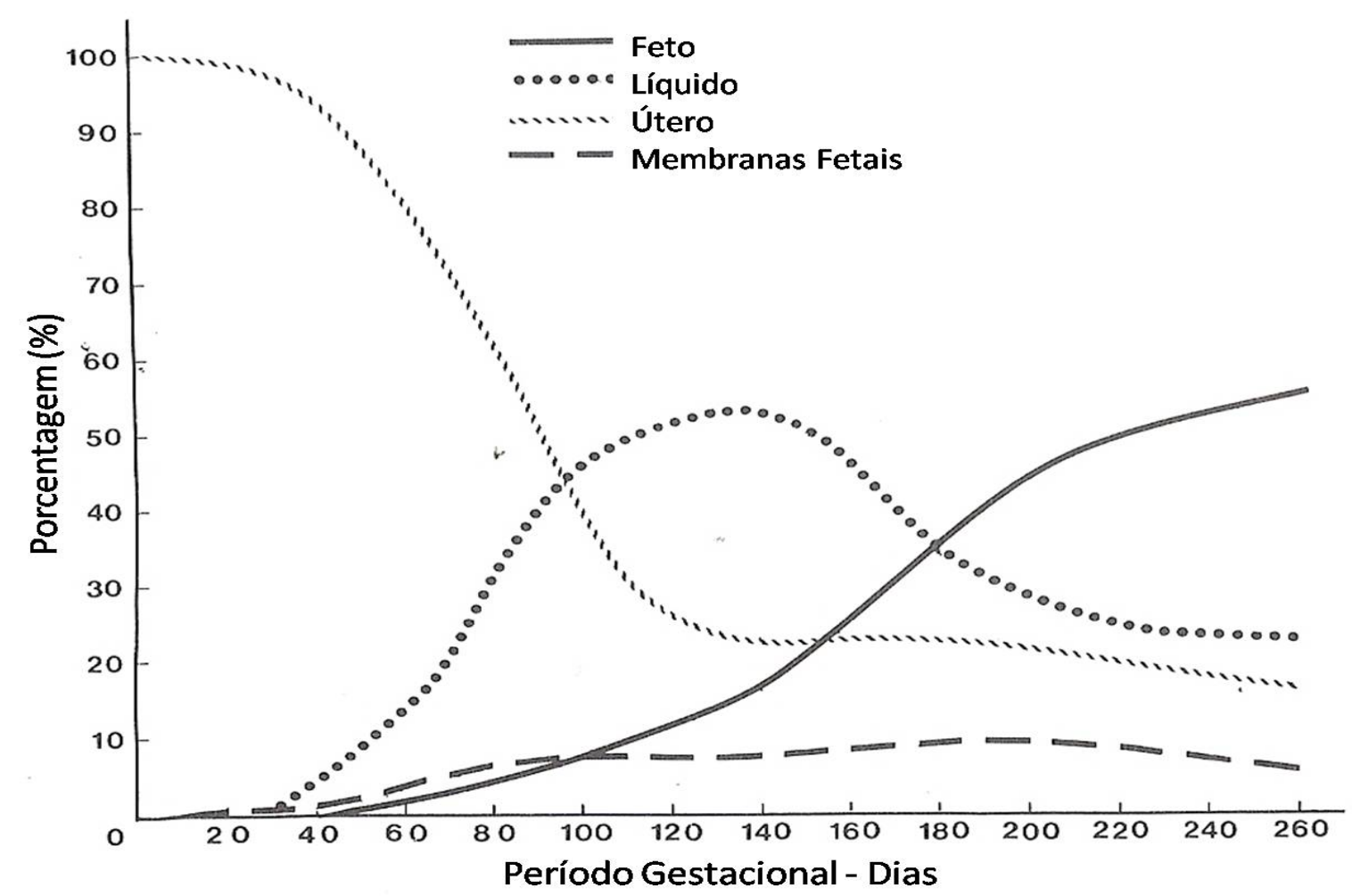

Fonte: (Modificado de SLOSS; DUFTY, 1980)

Figura 3.3 - Mudanças relativas aproximadas no peso do feto, fluidos intra-uterinos, útero e das membranas fetais durante a gestação de bovinos

Arthur (1969) e Eley et al. (1978) demonstraram a existência de um aumento significativo de fluido uterino na primeira metade gestacional, com três fases ou períodos de crescimento durante a gestação. O primeiro ( dois meses) e o terceiro ( $\sim$ sete meses $)$ períodos são atribuídos ao desenvolvimento do alantóide e o segundo ( 140 dias) ao do âmnio (ARTHUR, 1969; SLOSS; DUFTY, 1980). Eley et al. (1978) também observaram este crescimento exponencial de fluido alantóico no primeiro trimestre, argumentando que a expansão inicial visa expandir o corioalantóide, acarretando na aposição e contato desta membrana ao tecido materno, formando a placenta. Próximo ao parto, entre 15 e 20 litros de líquido se encontram no útero, representando cerca de 20 a $25 \%$ do peso total do útero gravídico, sendo dois terços deste volume atribuídos ao alantóide (SLOSS; DUFTY, 1980). 


\subsection{ALTERAÇÕES EM CONCEPTOS DECORRENTES DA PRODUÇÃO IN VITRO DE EMBRIÕES}

Na última década, pesquisadores (HILL et al., 1999, 2000, 2001; CHAVATTEPALMER et al., 2002, 2004, 2006; BERTOLINI et al., 2002a,b, 2004, 2006; PEDERSEN et al., 2005; SAKAI et al., 2005; WAKISAKA-SAITO et al., 2006; BATCHELDER et al., 2007a,b; FLETCHER et al., 2007; MIGLINO et al., 2007; EVERTS et al., 2008; ZHOU et al., 2008) vêm relatando alterações morfológicas, bioquímicas e de expressão gênica, vinculadas aos procedimentos de produção de embriões in vitro, incluindo anormalidades fetais e placentárias; altas taxas de mortalidade embrionária e/ou fetal precoce; hidropsia das membranas fetais; incremento de abortos em gestações avançadas; prolongamento da gestação por uma falha de sinalização do parto; comprometimento da mamogênese que parece afetar a lactogênese; aumento da incidência de partos distócicos; peso anormal dos neonatos; alta mortalidade peri-natal e aumentada na fase adulta; hemograma e concentração hormonal alterada no peri-parto, entre tantas outras anormalidades. Desta maneira, por este conjunto múltiplo de sintomas que compõe a AOS, Farin, Piedrahita e Farin (2006) classificaram esta síndrome em Tipos, de acordo com o grau de anormalidades apresentadas: Tipo I, severas alterações que culminam com a morte embrionária; Tipo II, desenvolvimento anormal das membranas placentárias ou fetais que levam ao aborto do feto na fase fetal; Tipo III, alterações que permitem o desenvolvimento da gestação, mas levam à morte peri-natal; e Tipo IV, anormalidades moderadas do feto e placenta que permitem o nascimento e desenvolvimento normal ou anormal do neonato. Como Wells et al. (2004) relataram que mais de $8 \%$ de bovinos clonados morrem até o quarto ano de vida, Bertolini et al. (2007) sugeriram ainda uma quinta classificação para esta síndrome compreendendo o período juvenil e adulto, já que animais produzidos in vitro apresentam uma maior morbidade e mortalidade neste período em decorrência das prováveis alterações sofridas durante a vida uterina.

Estas alterações compreendem todas as fases de crescimento e desenvolvimento ao longo da gestação e podem ser mais bem compreendidas analisando-se cada período individualmente. 
$\underline{\text { Fase de pré-implantação }}$

O reduzido número de publicações investigando as alterações que ocorrem neste periodo produziu alguns resultados conflitantes. Conceptos produzidos in vitro nesta fase apresentaram um maior desenvolvimento nos dias 12 (LAZZARI et al., 2002) e 17 (FARIN; CROSIER; FARIN, 2001) quando comparados a embriões in vivo. Entretanto, Bertolini et al. (2002b) verificaram resultados opostos, com um desenvolvimento retardado aos 16 dias, com conceptos produzidos in vitro com trofoblastos e discos embrionários menores. Como a composição dos meios utilizados para a produção dos embriões in vitro afeta 0 desenvolvimento do disco embrionário (FISCHER-BROWN et al., 2005), estes resultados contrastantes podem ser um reflexo das diferenças dos sistemas de PIV. Todavia, a hipótese de que os embriões PIV sejam menores é mais promissora e fundamentada, visto as taxas de prenhez serem inferiores em embriões PIV do que para embriões produzidos in vivo. Estes resultados sugerem que os conceptos PIV, presumivelmente os menores, são eliminados por não conseguirem ocupar físicamente o lúmen uterino, por exemplo, para evitar a secreção de Prostaglandina $\mathrm{F}_{2 \alpha}\left(\mathrm{PGF}_{2 \alpha}\right)$ por parte do endométrio no momento do reconhecimento materno da prenhez (15-16 dias de gestação). Ademais, os embriões ou fetos PIV são menores nos estádios iniciais de implantação (BERTOLINI et al., 2002b; CHAVATTE-PALMER et al., 2006).

\section{$\underline{\text { Fase de implantação }}$}

Nesta fase, um crescimento bifásico de conceptos PIV foi demonstrado por distintos grupos de pesquisa. Primeiramente, uma restrição ao crescimento foi observada no final da fase embrionária e no início da fase fetal (BERTOLINI et al., 2002a; CHAVATTE-PALMER et al., 2006). Após este período de restrição, ocorre um rápido crescimento (compensatório) posterior aos 60 dias de gestação. Este fenômeno foi seguido por um desvio de desenvolvimento do tecido placentário em prenhezes de FIV (BERTOLINI et al., 2002a; 2004) e TNCS (BATCHELDER et al., 2005), restaurando o tamanho do feto no final do primeiro trimestre da prenhez. Estes eventos culminam tanto na morte fetal como no desenvolvimento de neonatos aumentados de tamanho e com placentas morfologicamente alteradas (BERTOLINI; ANDERSON, 2002; BERTOLINI et al., 2002a, 2004, 2006).

Baseando-se em exames histológicos, Hill et al. (2000) sugeriram a existência de pelo menos três fenótipos de placenta em prenhezes oriundas de embriões PIV/TNCS, os quais 
determinam a viabilidade inicial do concepto: (a) placenta subdesenvolvida, placenta rudimentar que promove a morte embrionária antes ou próximo do completo estabelecimento da placentação (antes dos 45 dias); (b) placenta mal formada, com reduzida área de troca materno-fetal e que invariavelmente ocasiona a morte fetal antes dos 60 dias; (c) placenta normal, permite o desenvolvimento subseqüente, mas apresenta uma redução no número de placentônios. Estes três fenótipos de placenta estão associados direta e/ou indiretamente às alterações que propiciam a classificação por tipos da AOS, proposta por Farin, Piedrahita e Farin (2006), sendo que os fenótipos "a", "b" e "c" parecem estar relacionados aos tipos I, II e III/IV, respectivamente.

\section{$\underline{\text { Fase fetal }}$}

A fase fetal apresenta as alterações mais facilmente identificadas macroscopicamente. Estas manifestações incluem abortos, altas taxas de hidropsias das membranas fetais, gestações prolongadas com sinalizações do parto atenuadas ou inexistentes, distocia e nascimentos de animais com peso aumentado e com reduzida sobrevivência pós-parto.

As perdas gestacionais entre os dias 30 e 60 de gestação são significativamente maiores em embriões PIV, variando de 15 a 60\% para embriões FIV e de 40 a $100 \%$ em embriões produzidos por TNCS (WELLS; MISICA; TERVIT, 1999; HILL et al., 2000; BERTOLINI; ANDERSON, 2002; HEYMAN et al., 2002; BATCHELDER et al., 2005). As taxas de hidropsias em gestações normais derivadas de embriões produzidos in vivo por superovulação ou inseminação artificial são menores que $0,1 \%$ (1/1400 to 1/7500), mas passam a ser menores que $2 \%$ em gestações de embriões FIV (1/55 to 1/200) e variam aproximadamente de zero a 60\% em prenhezes de embriões clones (HASLER et al., 1995; LI et al., 2005; CONSTANT et al., 2006). Li et al. (2005) detectaram mudanças significativas na composição de fluidos amnióticos e alantóicos em prenhezes PIV. Em geral, a homeostase de eletrólitos apresenta-se compromissada, com um maior ou menor grau de alteração, sugerindo problemas nas funções renais do feto. Em contraste, Bertolini et al. (2004) não observaram alterações significantes na composição dos fluidos fetais nos dias 90 e 180 de gestação, apenas um aumento de volume alantóico aos 180 dias em gestações FIV. Constant et al. (2006) descreveram mudanças morfométricas de placentônios em gestações de embriões clones em decorrência a hidropsias desenvolvidas no terço final de gestação.

Morfologicamente e histologicamente, placentas de embriões PIV são significativamente afetadas durante a gestação, com aberrações mais expressivas ocorrendo da 
metade para o final da gestação. Observações comuns no terceiro trimestre presentes em prenhezes clones de ruminantes incluem a formação de um reduzido número de placentônios (HILL et al., 2000, 2001; DE SOUSA et al., 2001; CHAVATTE-PALMER et al., 2002; FLETCHER et al., 2007), um aumento no tamanho de placentônios acompanhado de edema e/ou áreas hemorrágicas (HILL et al., 2001; CHAVATTE-PALMER et al., 2002), redução da área de vascularização e vasculogênese fetal, e espessamento da membrana basal do trofoblasto (DE SOUSA et al., 2001; PALMIERI et al., 2007). Ainda, observam-se o achatamento do epitélio uterino e alargamento do tecido conectivo fetal (CONSTANT et al., 2006), e o aumento significativo do cordão umbilical. Significativas alterações da expressão gênica no tecido placentário também foram encontradas em embriões produzidos in vitro (EVERTS et al., 2008; ZHOU et al., 2008).

Miglino et al. (2007) em um amplo estudo morfológico e histológico compreendendo 31 placentas oriundas de bovinos clonados de diferentes grupos de pesquisa brasileiros, observaram o aparecimento comum de fusão de placentônios, implicando em um aumento no tamanho mas uma redução de número. Os autores encontraram extensas áreas da membrana corioalantóide com ausência de placentônios, edema das membranas fetais e do cordão umbilical, um aumento no número de microcotilédones acessórios funcionais $(<1 \mathrm{~cm})$, e de extensas áreas hemorrágicas confinadas aos placentônios e presentes também na região interplacentomal (áreas entre os placentônios). Ademais, estes pesquisadores encontraram criptas carunculares dilatadas, acomodando mais de uma vilosidade primária, com a ausência de densos complexos vasculares em forma de "loops" e de dilatações sinusoidais características de gestações bovinas normais.

\section{$\underline{\text { Peri-parto }}$}

O período peri-parto está associado a alterações que caracterizam os Tipos III/IV da AOS, e compreendem o prolongamento da gestação, uma menor preparação fisiológica da fêmea pré-parto, afetando a evolução dos estágios da parição, e um comprometimento da mamogênese pré-parto que parece afetar a lactogênese pós-parto. A dificuldade de parição e a freqüente necessidade da realização de cesarianas em prenhezes de FIV e TNCS também afetam a sobrevivência e a futura fertilidade das fêmeas receptoras, repercutindo em prejuízos econômicos adicionais.

Em ruminantes e na maioria das espécies domésticas, o parto é iniciado por eventos fisiológicos que incluem mudanças nos níveis de pelo menos dois hormônios esteróides, a 
progesterona, ou $\mathrm{P}_{4}$, e o estradiol, ou $\mathrm{E}_{2}$ (CONLEY; MASON, 1990). O estabelecimento e a manutenção da prenhez são absolutamente dependentes da produção de $\mathrm{P}_{4}$, a qual tem origem no corpo lúteo e/ou na placenta (GEISERT; CONLEY, 1998). Conseqüentemente, a conclusão da prenhez ou indução do parto podem ser induzidas pela redução da $\mathrm{P}_{4}$ por luteólise e/ou pela cessão da produção de $\mathrm{P}_{4}$ pela placenta, dependendo do estágio da gestação (CONLEY; FORD, 1987). Hill e Chavatte-Palmer (2002) correlacionaram os perfis de $\mathrm{P}_{4}$ materno nas últimas duas semanas da gestação com a viabilidade pós-natal em clones de TNCS, observando que perfis anormais (falha na queda de $\mathrm{P}_{4}$ pré-parto) pareciam estar associados à baixa viabilidade do neonato, enquanto que perfis normais se associavam a uma maior viabilidade pós-natal. O segundo elemento crítico nos eventos que conduzem ao parto é o aumento significativo na síntese de $\mathrm{E}_{2}$ (CHALLIS; THORBURN, 1975), o qual estimula a expressão de receptores de oxitocina no endométrio, a síntese de prostaglandina, a dilatação cervical, o relaxamento do ligamento sacro-isquiático e a distensibilidade da vulva (HUSZAR; WALSH, 1991; JENKIN; YOUNG, 2004). Estes eventos são comumente de menor expressão em prenhezes de FIV ou TNCS. O mecanismo fisiológico desencadeador comum para o início do parto em bovinos e em outras espécies domésticas é a ativação e maturação do córtex adrenal fetal, o que estimula um aumento na secreção de cortisol fetal (CHALLIS et al., 2000). Porém, os mecanismos pelos quais o cortisol induz o aumento de expressão das enzimas esteroidogênicas para a síntese de $\mathrm{E}_{2}$ e a queda da $\mathrm{P}_{4} \mathrm{e}$ as razões das falhas na inicialização do parto em prenhezes de FIV ou TN são desconhecidas.

O peso ao nascer é um dos fatores determinantes na sobrevivência perinatal, sendo o nascimento de bezerros com excesso de peso, fator comum e típico da AOS, a maior causa de mortalidade neonatal em bovinos (FERRELL, 1989). Um relativo baixo número de embriões clonados sobrevivem a termo ( 1 a $5 \%$ ), os quais frequentemente necessitam atendimento clínico intensivo após o parto (HILL; CHAVATTE-PALMER, 2002). A alta mortalidade neonatal, os problemas clínicos no período peri-parto e uma tendência a uma menor sobrevida pós-natal em clones por TNCS são problemas comuns já descritos por muitos grupos (RENARD et al., 1999; HILL et al., 1999, 2000; KATO; TANI; TSUNODA, 2000; CHAVATTE-PALMER et al., 2004). O acompanhamento de bezerros clonados até a fase adulta evidenciou taxas de mortalidade de $33 \%$ do parto ao desmame, e mais de $8 \%$ do desmame aos 4 anos de idade (WELLS et al., 2004). Apesar dos problemas pós-parto iniciais, bezerros clonados tendem a normalizar, mas ainda há uma maior morbidade e mortalidade durante o período juvenil (RUDENKO et al., 2004). 


\subsection{COMPROMETIMENTO DA RESTRIÇÃO PLACENTÁRIA AO CRESCIMENTO FETAL NO TERÇO FINAL DA PRENHEZ}

Distúrbios na placentação e/ou função placentária podem alterar o padrão de crescimento pré-natal (SCHLAFER; FISHER; DAVIES, 2000). De fato, a ocorrência de anormalidades placentárias associadas a problemas de desenvolvimento fetal em estágios iniciais (STICE et al., 1996; HILL et al., 2000; BERTOLINI et al., 2002a) ou tardios da gestação (HILL et al., 1999, 2001; BERTOLINI et al., 2002a, 2004) em prenhezes oriundas da PIV de embriões bovinos está correlacionada ao nascimento de bezerros com peso excessivo e menor sobrevivência pós-natal (BEHBOODI et al., 1995; BERTOLINI et al., 2002a; BATCHELDER et al., 2005). Como as expressões de genes com caráter de imprinting parecem ser mais susceptíveis a alterações epigenéticas pela PIV de embriões (MOORE, 2001), e levando-se em consideração a teoria evolutiva correlacionando o imprinting genômico à placentação (HAIG; GRAHAM, 1991; MOORE; HAIG, 1991; JOHN; SURANI, 2000), alterações na expressão de genes com caráter de imprinting, refletir-se-ão em desvios de desenvolvimento ou função placentárias (BERTOLINI et al., 2002a, 2004).

Conforme mencionado anteriormente, o crescimento fetal ocorre de forma lenta durante o início da gestação e exponencialmente em seu final (ELEY et al., 1978; PRIOR; LASTER, 1979; FERRELL, 1989; REYNOLDS et al., 1990), com 90\% do peso ao nascer sendo alcançado no último trimestre da gestação (FERRELL, 1989). A placenta por sua vez cresce mais rapidamente que o feto no início, com o peso placentário sendo maior do que o fetal no primeiro terço da gestação. Este período inicial de maior crescimento placentário é considerado importante para o estabelecimento da placenta, o que dará suporte ao crescimento fetal no segundo e terceiro trimestres da gestação (ELEY et al., 1978; PRIOR; LASTER, 1979; FERRELL, 1989; REYNOLDS et al., 1990). Entretanto, o sistema fetal normalmente

sofre uma restrição de crescimento no final da prenhez por fatores maternos e placentários, o que representa um mecanismo fisiológico homeostático que garante a sobrevivência materna, resguardando o balanço energético materno e prevenindo o excesso de crescimento fetal (FERRELL, 1991a,b; GLUCKMAN et al., 1992). Este conceito está relacionado ao controle do aporte de nutrientes no terceiro trimestre da gestação (GLUCKMAN et al., 1992), e o grau de restrição naquele período parece estar associado ao padrão de crescimento placentário na primeira metade da prenhez (BELL; HAY; EHRHARDT, 1999). Isto embasa o mecanismo placento-fetal de causa-e-efeito no qual o padrão de crescimento placentário inicial repercutir- 
se-á em um maior ou menor efeito "constritor" no crescimento fetal no final da prenhez (BELL; HAY; EHRHARDT, 1999), exatamente quando a demanda fetal por nutrientes atinge o seu máximo (PRIOR; LASTER, 1979; REYNOLDS et al., 1990).

Como a maioria dos nutrientes transferidos por meio da placenta são metabolizados ou produzidos por este tecido (FERRELL et al., 1983; FERRELL, 1989), alterações na função e metabolismo placentários podem modificar a modulação deste efeito constritor após a manipulação in vitro de embriões. Isto não gera surpresas, visto o tecido placentário normalmente demonstrar um alto grau de plasticidade frente a condições desfavoráveis, expressando mecanismos de adaptação a circunstâncias ambientais (FERRELL, 1989; KREBS; LONGO; LEISER, 1997; PENNINGA; LONGO, 1998;) ou nutricionais (MCEVOY et al., 1997; PERRY et al., 1999) adversas, o que podem promover alterações morfohistológicas na placenta e modular o crescimento placentário e fetal subsequente, como observado após a manipulação embrionária in vitro pela FIV e TNCS.

A placenta é virtualmente a única interface responsável pelas trocas entre os sistemas materno e fetal, exercendo um papel fundamental na regulação do crescimento fetal por causa de seu envolvimento na regulação do suprimento de nutrientes e à produção e transporte de hormônios, substratos e outras substâncias durante a prenhez. De fato, a disponibilidade e transporte de certos substratos ou hormônios durante a gestação é importante para o estabelecimento de padrões de funcionamento de sistemas fisiológicos no indivíduo em desenvolvimento, um fenômeno denominado de "programação metabólica" (MCMILLEN; ROBINSON, 2005). Esta hipótese sugere que alterações no suprimento de substratos ao concepto resultam em modificações moleculares e celulares permanentes ou mesmo novos padrões fisiológicos de funcionamento nos órgãos e sistemas fetais com implicações futuras, como a sobrevivência pós-natal. Estudos epidemiológicos em humanos associaram a condição de desnutrição pré-natal a um aumento na incidência de doenças cardiovasculares e metabólicas em indivíduos na vida adulta (BARKER, 1999). Este fenômeno foi denominado de "Hipótese de Barker" (BARKER, 1999), onde fatores causadores de alterações no ambiente uterino podem resultar em adaptações fisiológicas no feto em desenvolvimento, os quais por sua vez podem predispor o indivíduo a problemas cardio-vasculares, metabólicos e endócrinos na vida adulta, conforme evidenciado em várias espécies (GODFREY, 1998), o que parece confirmar o conceito da origem fetal de doenças na fase adulta (BERTRAM; HANSON, 2001). Consequentemente, alterações na reprogramação metabólica, com provável origem placentária em prenhezes de FIV e TNCS, podem afetar o controle da restrição do crescimento no final da gestação e a preparação para o parto, que podem também 
comprometer a sobrevida pós-natal (BERTOLINI et al., 2002a, 2004; BACTHELDER et al., 2007a,b).

Em estudos anteriores, observou-se que o crescimento fetal de conceptos oriundos de FIV e TNCS foi caracterizado por um padrão bifásico de crescimento, com um período de retardo na fase que coincide com o início da placentação. Este fenômeno foi seguido por um desvio de desenvolvimento do tecido placentário em prenhezes de FIV (BERTOLINI et al., 2002a, 2004) e TNCS (BATCHELDER et al., 2005), restaurando o tamanho do feto no final do primeiro trimestre da prenhez. Tal manifestação culmina com a ocorrência de um maior tamanho e pesos uterinos, placentários e fetais no terceiro trimestre da gestação, com alterações morfológicas significativas em placentas de FIV e TNCS e o nascimento de bezerros absolutamente grandes com menor sobrevida pós-natal (BERTOLINI; ANDERSON, 2002; BERTOLINI et al., 2002a; 2004; BATCHELDER et al., 2005). Tais alterações morfológicas também foram correlacionadas ao maior acúmulo de glicose e frutose no plasma e fluidos fetais em prenhezes de FIV. Cabe lembrar que uma porção substancial da função placentária está relacionada à regulação e à transferência materno-fetal de nutrientes ao feto (FERRELL, 1989), com a maioria dos metabólitos transferidos por meio da placenta sendo metabolizados e/ou produzidos pelo tecido placentário (FERRELL, 1989). O excessivo padrão de crescimento fetal observado no final da gestação de embriões PIV parece estar associado a um aumento no aporte de substratos energéticos aos tecidos útero-placetáriofetais, em especial a glicose (BERTOLINI et al., 2004).

A glicose é o substrato de maior relevância em meados da gestação, responsável por aproximadamente dois terços da demanda metabólica do concepto bovino. A frutose, por sua vez, é sintetizada pela placenta a partir da glicose, sendo o principal carboídrato no plasma e fluidos fetais, uma particularidade de espécies com placentas sinepitélio- ou epitélio-coriais, como os ungulados e cetáceos (GOODWIN, 1956; NIXON, 1963). Um aumento no aporte ou transporte de glicose pela placenta redireciona linearmente o uso deste substrato para rotas não-oxidativas, como a síntese de frutose (MEZNARICH et al., 1987; HAY, 1995; ALDORETTA; HAY, 1999). Alterações nas taxas de transferência, utilização ou partição de nutrientes pela placenta podem comprometer a regulação da restrição placentária ao crescimento fetal no final da gestação (GLUCKMAN et al., 1992). Como a massa placentária torna-se maior em prenhezes de FIV e TNCS, uma maior utilização ou aporte de glicose e frutose parece ocorrer, reduzindo a restrição placentária e favorecendo o crescimento fetal. Em adição, bezerros de FIV são maiores e apresentam concentrações elevadas de frutose imediatamente após o parto (BERTOLINI et al., 2004). É possível que a presença de frutose 
no plasma de recém nascidos seja metabolicamente e clinicamente favorável como fonte energética (gliconeogênese, produção de piruvato) pós-natal, sob condições de normóxia. Entretanto, desvios da normalidade (estresse respiratório pós-parto e hipóxia, comuns em bezerros de FIV e TNCS) podem conduzir a consequências metabólicas (acidose lática) que comprometam a sobrevivência pós-parto. Conseqüentemente, a maior massa e área placentárias em prenhezes a partir de embriões PIV sugere, pelo menos em parte, a existência de um aumento no aporte de nutrientes ao feto em prenhezes de FIV e TNCS que resulta em um desvio no crescimento pré-natal com possíveis implicações na sobrevida pós-natal (BERTOLINI et al., 2004).

Nos Capítulos confeccionados em forma de artigos científicos, apresentados a seguir, alguns pontos considerados nesta revisão serão mais bem abordados e discutidos, visando clarear a compreensão de alguns fatores técnicos e biológicos associados ao surgimento desta síndrome, e das diferenças que ocorrem em grupos pareados de animais controles e produzidos in vitro no decorrer da gestação. 
CAPÍTULO 1 DESENVOLVIMENTO IN VITRO DE EMBRIÕES BOVINOS CLONADOS PRODUZIDOS POR HANDMADE CLONING (HMC) PROVENIENTES DE DISTINTOS GENÓTIPOS E DE CULTIVOS CELULARES COM DIFERENTES CONFLUENCIAS ${ }^{1}$

\footnotetext{
${ }^{1}$ Artigo científico parcialmente publicado na revista Genetics and Molecular Research em fevereiro de 2010
} 


\section{INTRODUÇÃO}

A produção in vitro de embriões por transferência nuclear de célula somática (TNCS) evoluiu significativamente na última década. Entretanto, barreiras técnicas e biológicas mantêm a eficiência geral da clonagem ainda baixa. Entre estas, o procedimento per se está relacionado ao remodelamento incompleto do genoma (HUMPHERYS et al., 2002), que por sua vez está vinculado a um aumento no aparecimento de anormalidades fetais e placentárias e de perdas gestacionais posteriores (CONSTANT et al., 2006; FARIN; PIEDRAHITA; FARIN, 2006; BERTOLINI et al., 2007). A sincronia entre o ciclo celular do núcleo doador e do citoplasma receptor é considerado um dos fatores cruciais para o aumento da capacidade de reprogramação nuclear, e, conseqüentemente, da eficiência da clonagem (CAMPBELL et al., 1996).

Desde o nascimento do primeiro mamífero clonado por TNCS (WILMUT et al., 1997), muitas outras espécies animais foram clonadas de distintos tipos de células doadoras e genótipos (BERTOLINI et al., 2007). O efeito do genótipo ou do tipo de célula empregado dentro do mesmo genótipo vem sendo demonstrado na eficiência da clonagem, especialmente em camundongos (RIDEOUT et al., 2000; EGGAN et al., 2001; INOUE et al., 2003), com tal influência sendo também observada como relevante, para o correto desenvolvimento in vitro e in vivo, em bovinos (POWELL et al., 2004; BATCHELDER et al., 2005).

Levando-se em consideração o genótipo, um grande interesse existe no Brasil para a multiplicação de indivíduos de elevado mérito genético, com os animais da raça Nelore sobressaindo-se ante aos demais, devido a sua elevada importância econômica e por sua predominância na pecuária brasileira. Em adição, a conservação de genótipos de raças locais consideradas em risco de extinção, como a Crioula Lageana, uma raça única ao Brasil (SPRITZE et al., 2003), é também importante para o futuro da genética animal, visto que características específicas em um pool de genes pertencentes a um rebanho restrito podem sempre ser resgatadas e expandidas em uma população mais abrangente. A raça Crioula Lageana é muito bem adaptada ao ambiente dos planaltos e serras da região Sul do Brasil, originada praticamente por seleção natural de raças da península Ibérica trazidas por colonizadores nos séculos XVI e XVII. Esta raça é caracterizada por sua rusticidade, maturidade sexual tardia e elevada prolificidade, com a população atualmente estimada em menos de 500 animais, com mais de $80 \%$ alocados em um único rebanho (SPRITZE et al., 2003). O pequeno número de indivíduos remanescentes, associado com algumas 
características de elevado interesse da raça e de sua distante genética da raça Nelore, promove ou justifica os esforços para sua conservação, onde a clonagem reprodutiva pode ser de relevância.

A fase do ciclo celular parece ocupar uma parcela de grande relevância no sucesso da clonagem animal por TNCS. A utilização de células doadoras de núcleo no estágio quiescente de G0 ou estacionadas na fase G1 do ciclo celular tornaram-se predominantes na clonagem (GIBBONS et al., 2002), visto que estas fases do ciclo celular são consideradas por muitos investigadores como mais adequadas para a adequada reprogramação do genoma (CAMPBELL et al., 1996; WELLS; MISICA; TERVIT, 1999; KUBOTA et al., 2000; KUES et al., 2000; LIU; YU; JU, 2004). Em adição, o uso de células doadoras em qualquer outra fase do ciclo geralmente perturba ou impede o desenvolvimento embrionário após a clonagem, tanto pela "pulverização" do DNA induzida pela condensação prematura dos cromossomos na fase $\mathrm{S}$ do ciclo, quanto pela aneuploidia quando nas fases $\mathrm{G} 2 / \mathrm{M}$ do ciclo (CAMPBELL et al., 1996). Diversos protocolos já foram propostos ao longo dos anos para uma sincronização adequada das células doadoras nas fases G0/G1 do ciclo. Alguns protocolos requerem a manipulação das condições de cultivo, como a privação de soro (WILMUT et al., 1997) ou a inibição do ciclo celular por contato das células com elevada confluência em cultivo (BOQUEST; DAY; PRATHER, 1999). Entretanto, uma grande variação no tempo para uma adequada sincronização do ciclo celular ou da confluência em cultivo, com resultados ainda mais imprevisíveis, torna estes procedimentos pouco práticos em rotinas programadas de TNCS, e que requerem certo grau de experiência e conhecimento da linhagem celular ou do tipo de célula em uso (CHORESCA et al., 2009). De forma alternativa, alguns protocolos utilizam substâncias químicas que direta ou indiretamente bloqueiam o ciclo celular, como a roscovitina (GIBBONS et al., 2002), o dimetil sulfóxido (DMSO; HASHEM et al., 2006) ou a cicloheximida (GOISSIS et al., 2007). A utilização de tais agentes sincronizadores do ciclo pode ser efetiva, mas a ampla interferência com o processo celular, junto com os potenciais efeitos tóxicos, podem induzir a morte celular, o que pode ser consistente com danos ao DNA (KOO et al., 2009), juntamente com inesperadas conseqüências para o desenvolvimento posterior (GIBBONS et al., 2002).

Como observado anteriormente, todos os procedimentos de seleção de células em G0/G1 para a clonagem por TNCS apresentam vantagens e limitações. Entre todos, a inibição do ciclo celular por contato das células com elevada confluência em cultivo aparece atualmente como um dos métodos mais utilizados (CAMPBELL et al., 2007; SUN et al., 2008). Em tal procedimento, pela tentativa de induzir a inibição do crescimento por contato, 
mudanças no crescimento celular ou nas condições de cultivo podem ocasionalmente atrasar ou acelerar o crescimento celular, o que resulta em uma população celular sub-ótima para a clonagem, especialmente quando os cultivos podem estar sub-confluentes (CAMPBELL et al., 1996; CHO et al., 2005; CHORESCA et al., 2009). Recentemente, Sun et al. (2008) demonstraram que uma elevada proporção de células em G0/G1 $(91,4 \%)$ estavam presentes em cultivos celulares com elevada confluência na fase de platô da curva de crescimento celular (>95\% confluência), com esta proporção significativamente caindo (59,3\%) quando os cultivos estavam na fase logarítmica de crescimento (50-60\% confluência). Todavia, a relação entre o nível de confluência celular em uma placa de cultivo próximo ou na fase de platô da curva de crescimento celular e o desenvolvimento a blastocisto após a clonagem por TNCS ainda deve ser mais bem caracterizada. Por conseguinte, este estudo teve por objetivo avaliar o efeito de três intervalos distintos de confluência celular no desenvolvimento in vitro de embriões bovinos clonados por TNCS. Em adição, este trabalho também visou avaliar o efeito de duas linhagens genéticas distintas (Bos indicus, raça Nelore vs. Bos taurus, raça Crioulo Lageano) para utilização como núcleos doadores na clonagem no desenvolvimento embrionário subseqüente.

\subsection{MATERIAL E MÉTODOS}

Todos os reagentes utilizados neste estudo foram provenientes da Sigma-Aldrich Chemical Co. (St. Louis, MO, EUA), salvos os que são indicados à parte.

\subsubsection{Isolamento e Cultivo de Células Cutâneas de Bovinos}

Cultivos celulares primários foram estabelecidos a partir de biópsias assepticamente coletadas de orelhas de duas fêmeas bovinas adultas (Nelore e Crioulo Lageano, com 8 anos e 8 meses de idade, respectivamente), seguindo os procedimentos descritos por Ribeiro et al. (2009). Brevemente, após a coleta, tecidos da orelha de ambos os animais foram seccionados em fragmentos de 3 a $4 \mathrm{~mm}$ e dispostos em placas de cultivo celular de $35 \mathrm{~mm}$ (Corning Incorporated, NY, EUA) contendo 0,8 mL de meio de cultivo (DMEM, Dulbecco's Modified 
Eagle's Medium, Gibco-BRL, NY, EUA), acrescido de 0,22 mM de piruvato de sódio, 26,2 $\mathrm{mM}$ de bicarbonato de sódio, $100 \mathrm{UI} / \mathrm{mL}$ de penicilina $\mathrm{G}, 100 \mu \mathrm{g} / \mathrm{mL}$ de sulfato de estreptomicina, 0,25 $\mu \mathrm{g} / \mathrm{mL}$ de anfotericina B e 10\% de Soro Fetal Bovino (SFB, GibcoBRL). Os cultivos foram estabelecidos, mantidos e expandidos em incubadora a $38,5^{\circ} \mathrm{C}$, com atmosfera controlada de $5 \%$ de $\mathrm{CO}_{2}$ em umidade saturada até o momento da rotina de clonagem.

\subsubsection{Produção de Embriões Bovinos}

Embriões bovinos foram produzidos por Handmade Cloning (HMC) ou por partenogênese, baseando-se em nossos procedimentos já estabelecidos (RIBEIRO et al., 2009), e segundo os experimentos descritos abaixo.

Experimento 1: Efeito do genótipo (Nelore vs. Crioulo Lageano) no desenvolvimento $\underline{\text { in vitro de embriões clonados. }}$.

Células somáticas da pele de fêmeas bovinas adultas, provenientes de uma Nelore (NEL) e uma Crioula Lageana (CL), cultivadas até a quarta passagem, foram utilizadas para a reconstrução embrionária (100\% do volume) por HMC. A confluência celular de ambos os animais variou de 70 a 95\% no momento da reconstrução.

Experimento 2: Efeito da confluência celular no desenvolvimento in vitro de embriões clonados.

Apenas células da fêmea Nelore foram utilizadas neste experimento. Antes de cada procedimento de clonagem, os cultivos celulares foram morfologicamente avaliados e segregados em três intervalos distintos de confluência celular, próximos ou no exato platô de crescimento: (B) baixa confluência, 70-80\%; (M) média confluência, 80-90\%; e (A) alta confluência, $>95 \%$. Em seguida, as células foram utilizadas para a reconstrução de hemiembriões (50\% do volume) e de embriões (100\% do volume), como descritos abaixo.

Maturação in vitro (MIV) e seleção de citoplastos - Após $17 \mathrm{~h}$ de maturação in vitro de complexos cumulus-oócito (CCOs) aspirados de ovários bovinos coletados de um frigorífico local, os CCOs foram desnudos por pipetagem contínua em meio M199H composto por TCM-199 (M2520), suplementado com 2,4 mM de $\mathrm{NaHCO}_{3}, 2,0 \mathrm{mM}$ de 
piruvato de sódio e $10 \%$ de SFB. Em seguida, os oócitos maturados foram selecionados pela presença do $1^{\mathrm{o}}$ corpúsculo polar. Destes, removeu-se a zona pelúcida (ZP) pela breve exposição a uma solução de protease a 0,5\% em $\mathrm{M} 199 \mathrm{H}+0,01 \%$ de álcool polivinílico (PVA). Em seguida, os oócitos sem ZP foram incubados por $10 \mathrm{~min}$ em $5 \mu \mathrm{g} / \mathrm{mL}$ de citocalasina B em M199H + 10\% de SFB, e submetidos à bisecção manual, sob óleo mineral, utilizando-se uma lâmina de bisecção (Ultra-sharp Splitting Blade, Bioniche Inc., EUA), sob lupa estereomicroscópica. Após a bisecção, e seguindo-se a incubação em $10 \mu \mathrm{g} / \mathrm{mL}$ de bisbenzimida (Hoechst 33342) em M199H + SFB por $10 \mathrm{~min}$, os hemi-oócitos contendo aproximadamente $50 \%$ do volume citoplasmático original foram selecionados em um microscópio invertido de epifluorescência com filtro UV em enucleados e nucleados, conforme a presença da placa metafásica.

Reconstrução embrionária e ativação - Para a reconstrução embrionária, um ou dois hemi-oócitos enucleados (hemi-citoplastos) foram rapidamente expostos a $500 \mu \mathrm{g} / \mathrm{mL}$ de fitohemaglutinina (PHA) em M199H + 0,01\% PVA, e em seguida, aderidos a uma célula somática, compondo aproximadamente 50 ou $100 \%$ do volume citoplasmático final, respectivamente. Apenas células pequenas, redondas e com a membrana lisa e intacta foram utilizadas na reconstrução, tentando aumentar a proporção de células nas fases G0/G1 do ciclo celular (BOQUEST; DAY; PRATHER, 1999). Os hemi-embriões (50\% do volume) e embriões (100\% do volume) reconstruídos foram eletro-fusionados mediante dois pulsos de $1,2 \mathrm{kV} / \mathrm{cm}$ por $10 \mu \mathrm{sec}$ cada, após uma breve exposição a um pré-pulso de $30 \mathrm{~V}$, em $650 \mu \mathrm{L}$ de meio de eletrofusão (300 mM de manitol, $0,05 \mathrm{mM}$ de $\mathrm{CaCl}_{2} \cdot 2 \mathrm{H}_{2} \mathrm{O}, 0,1 \mathrm{mM}$ de $\mathrm{MgSO}_{4} \cdot 7 \mathrm{H}_{2} \mathrm{O}, 0,5 \mathrm{mM}$ de Hepes e $0,01 \%$ de PVA), em uma câmara de fusão (BTX 453, BTX Instruments, Genetronics, CA, EUA), acoplada a um aparelho de eletrofusão (Voltain ${ }^{\mathrm{TM}} \mathrm{EP}-1$ Cell Fusion System, Cryologic, Australia). A avaliação das estruturas fusionadas ocorreu entre 60 e 90 min após a fusão, seguida da ativação química dos embriões e hemi-embriões clones reconstruídos, e dos oócitos com zona pelúcida intacta (grupo controle por partenogênese) em $5 \mu \mathrm{M}$ de ionomicina em M199H por $5 \mathrm{~min}$, seguido da incubação individualizada em $5 \mu \mathrm{L}$ de M199 + SFB contendo 2 mM de 6-dimetilaminopurina (6DMAP), sob óleo mineral, durante $4 \mathrm{~h}$. A ativação iniciou-se $24,8 \pm 1,0 \mathrm{~h}$ após o início da maturação, com um intervalo de fusão-ativação de $2,5 \pm 0,8 \mathrm{~h}$.

Cultivo in vitro (CIV) de embriões e hemi-embriões clonados e de embriões partenogeneticamente ativados. 
No Experimento 1, embriões clonados ativados (100\% do volume) foram cultivados in vitro individualmente em micro-poços utilizando o sistema Well-of-the-Well (WOW), ou de micro-poços, de acordo com Vajta et al. (2000), e modificado por Feltrin et al. (2006).

No Experimento 2, um embrião clonado (1 x 100\%) ou dois hemi-embriões clonados (2 x 50\%, agregados) foram colocados em cada micro-poço (WOW), compondo aproximadamente $100 \%$ do volume citoplasmático normal final por micro-poço.

Todas as estruturas foram cultivadas in vitro em poços de placas 4-poços (Nunclon ${ }^{\circledR} 144444$, Nunc, Roskilde, Dinamarca) contendo $400 \mu \mathrm{L}$ de meio SOFaaci (HOLM et al., 1999) suplementado com 0,34 mM de citrato tri-sódico, 2,77 mM de mio-inositol, 30 $\mu \mathrm{L} / \mathrm{mL}$ de aminoácidos essenciais e $10 \mu \mathrm{L} / \mathrm{mL}$ de aminoácidos não essenciais, acrescido de $5 \%$ de SEE, $5 \mu \mathrm{g} / \mathrm{mL}$ de insulina, $5 \mu \mathrm{g} / \mathrm{mL}$ de transferrina e $5 \mathrm{ng} / \mathrm{mL}$ de selenito de sódio, sob óleo mineral, utilizando o sistema Foil Bag (VAJTA et al., 1997), com atmosfera de 5\% de $\mathrm{CO}_{2}, 5 \%$ de $\mathrm{O}_{2}$ e $90 \%$ de $\mathrm{N}_{2}$, a $38,5^{\circ} \mathrm{C}$ por $168 \mathrm{~h}$ (início da ativação = hora 0 ) até o estádio de blastocisto. Com 48 h de CIV realizou-se a avaliação da clivagem embrionária. Em ambos os experimentos, os grupos controles contendo embriões partenotos com zona pelúcida intacta foram cultivados in vitro sob as mesmas condições descritas acima, exceto que para estes grupos, utilizaram-se os poços das placas 4-poços para o cultivo e não os micro-poços utilizados para os clones. Os grupos partenotos serviram como controle para a qualidade oocitária, de manipulação e de condições de cultivo em cada procedimento.

\subsubsection{Análise Estatística}

As taxas de fusão, clivagem e de blastocisto em ambos os experimentos foram comparadas pelo teste do $\chi^{2}$ (Minitab, State College, PA, EUA), para $\mathrm{P}<0,05$. No Experimento 2, a dependência da taxa de desenvolvimento em cada intervalo de confluência celular foi analisada por regressão linear usando o mesmo programa estatístico. 


\subsection{RESULTADOS}

Experimento 1: Efeito do genótipo (NEL vs. CL) no desenvolvimento in vitro de embriões clonados.

Após 10 replicações, $65,5 \%$ dos CCOs colocados em maturação foram selecionados para a clonagem pela seleção da presença do $1^{\circ}$ corpúsculo polar $(1778 / 2843)$. Um total de 653 embriões foi reconstruído de 1438 hemi-oócitos enucleados, com taxas de fusão similares entre as doadoras de células CL (215/303, 71,0\%) e NEL (232/350, 66,3\%). A taxa de clivagem foi maior no grupo CL (201/213, 94,4\%) do que nos grupos NEL (183/229, 79,9\%) ou controle partenoto $(107 / 144,74,3 \%)$. Entretanto, o desenvolvimento posterior a blastocisto foi significativamente menor para o grupo CL $(19 / 213,8,9 \%)$ do que para os grupos Nelore $(48 / 229,21,0 \%)$ e partenoto $(33 / 144,22,9 \%)$.

Experimento 2: Efeito da confluência celular no desenvolvimento in vitro de embriões clonados.

Uma taxa de maturação de 65,6\% (2506/3822) foi observada após 11 replicações. Um total de 1897 hemi-citoplastos foram utilizados para a reconstrução de 455 hemi-embriões $(50 \%)$ e 695 embriões $(100 \%)$. A taxa de fusão para hemi-embriões $(234 / 455,51,4 \%)$ foi menor do que para os embriões $(470 / 695,67,6 \%$ ), com a confluência celular (CC) não apresentando efeito na fusão. Os resultados do desenvolvimento embrionário estão sumarizados na tabela 4.1. As taxas de clivagem foram similares entre todos os grupos, mas as taxas de blastocisto aumentaram linearmente $(\mathrm{R}=0,999, \mathrm{P}=0,023)$ com o incremento da confluência celular. As taxas médias de blastocistos para ambos os tipos de embriões combinados ( $2 \times 50 \%$ e 1 x 100\%) foram de 7,0\%, 17,5\%, e 29,4\% para os intervalos de confluência $\mathrm{B}, \mathrm{M}$, e A, respectivamente, com a confluência celular sendo um forte previsor para o desenvolvimento a blastocisto, conforme ilustrado na figura 4.1 (equação de regressão $\mathrm{y}=11,2 \mathrm{x}-4,4$, onde y é a taxa de blastocisto e $\mathrm{x}$ o intervalo de confluência celular). Aparentemente, o esquema de agregação não apresentou influência no desenvolvimento a blastocisto, com exceção dos grupos de Baixa confluência. 
Tabela 4.1 - Desenvolvimento in vitro de embriões bovinos clonados produzidos por transferência nuclear de células somáticas oriundas de cultivos de distintas confluências e de cultivos in vitro de embriões com diferentes esquemas de agregação, Laboratório de Reprodução Animal, UDESC - Lages, SC $-2007$

\begin{tabular}{|c|c|c|c|c|c|c|c|}
\hline \multirow{2}{*}{$\begin{array}{l}\text { Tipo de } \\
\text { Embrião }\end{array}$} & \multirow{2}{*}{$\begin{array}{c}\text { Confluência } \\
\text { do Cultivo } \\
\text { Celular }\end{array}$} & \multirow{2}{*}{$\begin{array}{c}\text { Esquema de } \\
\text { Agregação }\end{array}$} & \multirow{2}{*}{$\mathbf{n}^{\dagger}$} & \multicolumn{2}{|c|}{$\begin{array}{c}\text { Taxa de } \\
\text { Clivagem }\end{array}$} & \multicolumn{2}{|c|}{$\begin{array}{c}\text { Taxa de } \\
\text { Blastocisto }\end{array}$} \\
\hline & & & & n & $\%$ & n & $\%$ \\
\hline \multirow{6}{*}{ Clones } & \multirow{2}{*}{$70-80 \%(\mathrm{~B})$} & $2 \times 50 \%$ & 8 & 6 & 75,0 & 0 & $0,0^{\mathrm{a}}$ \\
\hline & & $1 \times 100 \%$ & 134 & 104 & 77,6 & 10 & $7,5^{\mathrm{b}}$ \\
\hline & \multirow{2}{*}{$80-90 \%(\mathrm{M})$} & $2 \times 50 \%$ & 34 & 22 & 64,7 & 7 & $20,6^{\mathrm{c}, \mathrm{d}}$ \\
\hline & & $1 \times 100 \%$ & 149 & 115 & 77,2 & 25 & $16,8^{\mathrm{c}}$ \\
\hline & \multirow{2}{*}{$>95 \%(\mathrm{~A})$} & $2 \times 50 \%$ & 50 & 42 & 84,0 & 17 & $34,0^{\mathrm{d}}$ \\
\hline & & $1 \times 100 \%$ & 164 & 130 & 79,3 & 46 & $28,0^{\mathrm{d}}$ \\
\hline Partenotos & $\mathrm{n} / \mathrm{a}$ & $1 \times 100 \%$ & 144 & 103 & 71,5 & 31 & $21,5^{\mathrm{c}, \mathrm{d}}$ \\
\hline
\end{tabular}

a,b,c,d: $\mathrm{P}<0,05$ (colunas); ${ }^{\dagger} 11$ replicações; "baseando-se no número de WOW; n/a: não aplicável.

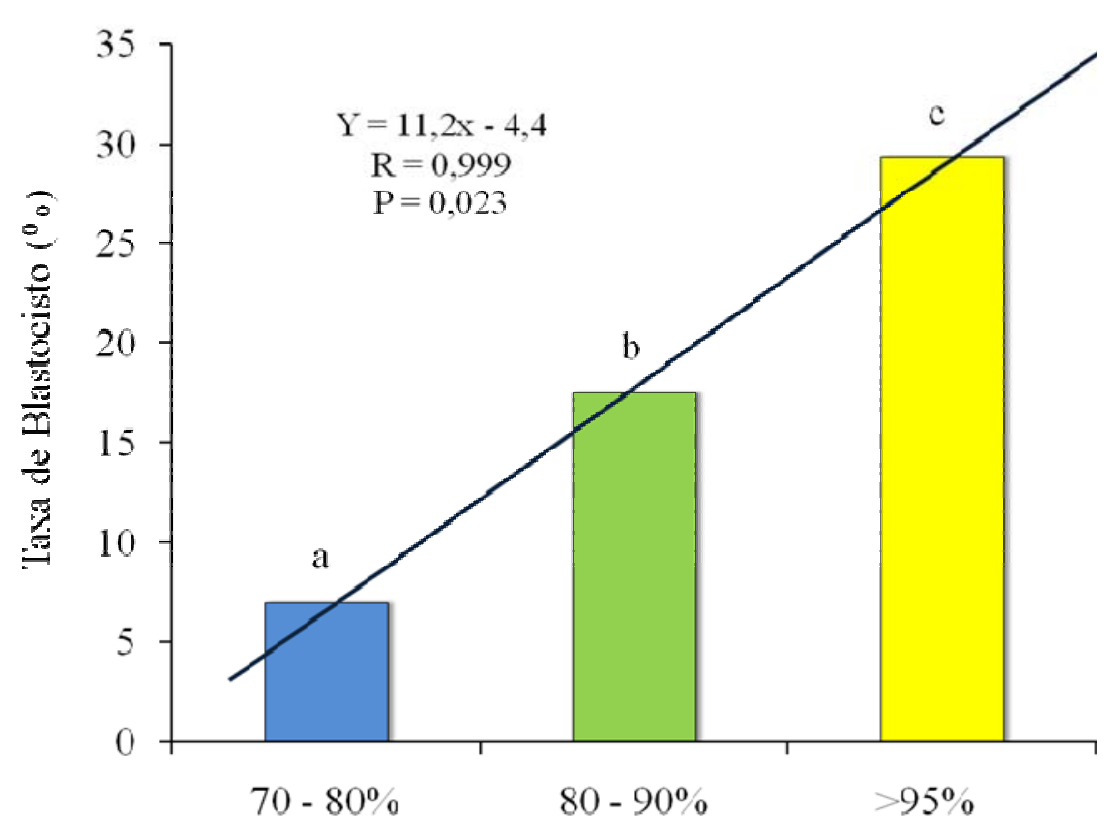

Intervalos de confluência no cultivo celular

Figura 4.1 - Taxas de blastocisto (\%) para embriões clonados, independente do esquema de agregação, reconstruídos com utilização de células com Baixa (70 - 80\%), Média (80-90\%) ou Alta (>95\%) confluência em cultivo. ${ }^{\text {a-c: }}$ Colunas com sobrescritos desiguais diferem, $\mathrm{P}<0,05$ 


\subsection{DISCUSSÃO}

Desde o sucesso do primeiro nascimento de um mamífero clonado oriundo da célula de um animal adulto (WILMUT et al., 1997), os procedimentos de TNCS evoluíram consideravelmente. No entanto, o processo da clonagem como um todo permanece ineficiente, com etapas cruciais ainda por serem refinadas e os eventos biológicos associados por serem completamente caracterizados. Até o momento, alterações pré- e pós-natais no desenvolvimento continuam a aparecer como conseqüências da clonagem por TNCS, limitando a transferência desta tecnologia para maiores aplicações comerciais e científicas (FARIN; PIEDRAHITA; FARIN, 2006; BERTOLINI et al., 2007).

O sucesso do desenvolvimento é dependente de numerosos fatores, incluindo o procedimento de transferência nuclear, a proficiência dos técnicos e do laboratório envolvidos, o tipo, fonte e qualidade do citoplasto receptor, o tipo e linhagem da célula doadora, o método de reconstrução, ativação e sistema de cultivo embrionário, e a fase do ciclo celular que a célula e o citoplasto se encontram (CAMPBELL et al., 2007). Algumas linhagens celulares e células doadoras parecem ser mais reprogramáveis do que outras (INOUE et al., 2003). Entretanto, comparações entre eficiências relatadas são difíceis de serem interpretadas devido a diferenças nos métodos utilizados para a produção dos embriões (CAMPBELL et al., 2007). Inoue et al. (2003) e Batchelder et al. (2005), em experimentos muito bem desenhados e sob condições experimentais controladas, observaram diferenças significativas no desenvolvimento in vitro e in vivo de embriões bovinos clonados de diferentes genótipos de células-doadoras e de linhagens celulares dentro do mesmo genótipo. Nossos dados também demonstram esta influência do núcleo doador no desenvolvimento de embriões clonados por HMC (Experimento 1), com células de Crioulo Lageano sendo menos viáveis para suportar o desenvolvimento até o estádio de blastocisto $(8,9 \%)$ do que células de Nelore $(22,9 \%)$. Como a confluência celular no momento da transferência nuclear variou entre 70 e 95\%, esta influência pode ser devida à habilidade de reprogramação per se de cada célula doadora ou genótipo, pela contribuição específica de fatores associados com a heteroplasmia embrionária e do mosaicismo citoplasmático pelo uso de dois citoplastos distintos para a reconstrução, ou mesmo a uma maior proporção de células em G0/G1 nas placas de cultivo da Nelore. Tais possibilidades necessitam ser verificadas no futuro.

A influência da confluência celular próximo ou na exata fase de platô da curva de crescimento celular no desenvolvimento embrionário in vitro subsequente foi demonstrada no 
Experimento 2. Um aumento significativo nas taxas de blastocisto (7,0\%, 17,5\%, e 29,4\%) seguiu linearmente o incremento na confluência celular. Tais diferenças no desenvolvimento são, provavelmente, devidas a uma maior proporção de células em G0/G1 em cultivos com maior confluência de células (A, no platô) quando comparadas com células na transição entre a fase logarítmica e de platô (B e M). A distribuição do ciclo celular por citometria de fluxo em cada poço de cultivo não foi possível de ser avaliada neste estudo, mas nossos resultados corroboram, pelo menos em parte, com um estudo anterior em que mais de $85 \%$ das células estavam em G0/G1 quando oriundas de cultivos com elevadas confluências, enquanto que cultivos celulares na fase logarítmica de crescimento (50-60\% de confluência) apresentavam apenas 74,1\% das células em G0/G1 (BOQUEST; DAY; PRATHER, 1999). A alta proporção de células nos estágios G0/G1 em populações celulares com elevada confluência foram recentemente demonstradas em bovinos (SUN et al., 2008), peixe-dourado (CHORESCA et al., 2009) e cães (KOO et al., 2009), que compararam diferentes métodos para a sincronização de células somáticas nesta específica fase, analisadas por citometria de fluxo.

Gibbons et al. (2002) compararam a privação de soro e o tratamento com roscovitina como protocolos de sincronização celular, e observaram uma taxa de desenvolvimento in vitro similar em ambos os tratamentos, mas um maior desenvolvimento in vivo utilizando roscovitina no cultivo celular antes do procedimento de clonagem. Da mesma forma, Choresca et al. (2009), após analisarem a privação de soro, cultivo até alta confluência, e tratamento com roscovitina em cultivo celular de peixe-dourado, e Koo et al. (2009), comparando o uso de privação de soro, cultivo até alta confluência, tratamentos com cicloheximida, DMSO e roscovitina em cultivo de células de cachorro, recomendaram o uso do roscovitina por uma ligeira maior proporção de células em $\mathrm{G} 0 / \mathrm{G} 1$, ou devido a uma resposta na sincronização mais rápida após o início deste tratamento do que nos outros protocolos. Entretanto, estes estudos avaliaram apenas a proporção de células em cada fase do ciclo celular no cultivo, mas não as utilizaram para a clonagem por TNCS. Utilizando células de bovinos estagnadas nas fases G0/G1, Sun et al. (2008) observaram que a inibição do crescimento por contato celular em cultivo com alta confluência foi mais efetivo para suportar o desenvolvimento a blastocisto do que por privação de soro no cultivo ( $58 \%$ vs. 44\%, respectivamente), enquanto que Hayes et al. (2005) não observaram qualquer diferença no desenvolvimento in vitro de embriões bovinos entre tratamentos. Apesar disto, os autores utilizaram apenas células em cultivo de elevada confluência para a clonagem, na fase de platô do crescimento, não avaliando a eficiência da clonagem com intervalos de confluência mais baixos. Coletivamente, os estudos acima apresentam resultados conflitantes, sugerindo um 
efeito benéfico com o uso do roscovitina para a sincronização do ciclo celular. Entretanto, providenciando-se um tempo mínimo necessário para os cultivos de células atingirem elevada confluência em placa, a proporção de células em G0/G1, nesses estudos, pareceram ser maiores do que em qualquer outro protocolo empregado. Sendo assim, a privação de soro ou o uso de agentes químicos para a sincronização do ciclo celular antes da clonagem por transferência nuclear não só impõe uma condição potencial de estresse ou de toxicidade nas células, mas também não parece promover qualquer melhora no desenvolvimento de embriões quando comparado com a inibição por contato celular de cultivos em alta confluência.

A avaliação do potencial benefício da agregação embrionária no cultivo do Experimento 2 se baseou em estudos anteriores, incluindo os nossos, cujo aumento das taxas de blastocisto e/ou de melhor qualidade embrionária foi observada após a agregação de embriões clonados murinos (BOIANI et al., 2003) ou bovinos (MISICA-TURNER et al., 2007; RIBEIRO et al., 2009) durante o cultivo in vitro. Dentro de cada intervalo de confluência, o esquema de agregação não apresentou influência no desenvolvimento a blastocisto. Entretanto, o grupo 2 x 50\% do intervalo de confluência intermediário (M) demonstrou um padrão similar de desenvolvimento a ambos os grupos de embriões $(2 \times 50 \%$ e $1 \times 100 \%$ ) que utilizaram células com a maior confluência (A). Tais dados sugerem que a agregação de embriões pode promover um efeito parácrino positivo no desenvolvimento embrionário, talvez tornando-se mais evidente quando as células doadoras encontram-se em condições sub-ótimas, corroborando com observações de outros pesquisadores (BOIANI et al., 2003; MISICA-TURNER et al., 2007). Entretanto, o benefício da agregação de embriões no desenvolvimento de embriões clonados, variando as condições de cultivo das células doadoras, ainda necessita ser mais bem elucidado.

Em resumo, nossos dados indicam que a eficiência da clonagem com células somáticas pode ser melhorada significativamente, dependendo do genótipo da célula utilizada para a reconstrução embrionária, mas outros fatores associados com o procedimento de clonagem per se também podem influenciar os resultados de desenvolvimento subseqüente. Além disto, foi demonstrada a existência de um efeito linear positivo do nível de confluência celular próximo ou na fase de platô no desenvolvimento in vitro de embriões após a clonagem por TNCS. A inibição do crescimento por contato das células é um eficiente método para a sincronização do ciclo celular prévio à clonagem. 
CAPÍTULO 2 EFEITO DO INTERVALO FUSÃO-ATIVAÇÃO E DA AGREGAÇÃO EMBRIONÁRIA NO DESENVOLVIMENTO IN VITRO E IN VIVO DE EMBRIÕES BOVINOS CLONADOS PRODUZIDOS POR HANDMADE CLONING (HMC) ${ }^{2}$

\footnotetext{
${ }^{2}$ Artigo a ser submetido para a revista Reproduction, Fertility and Development
} 


\section{INTRODUÇÃO}

A produção in vitro de embriões por transferência nuclear de célula somatica (TNCS) evoluiu significativamente nas últimas décadas. Entretanto, a ineficiência do processo como um todo ainda é frustrante, com apenas 3-5\% dos embriões transferidos chegando a termo (FULKA; FULKA, 2007). Esta ineficiência se manifesta em diferentes níveis, com alterações moleculares, histológicas, morfológicas e fisiológicas comprometendo o desenvolvimento embrionário, fetal e neonatal subseqüentes, em um conjunto de sintomas coletivamente denominado de Abnormal Offspring Syndrome ou Síndrome do Neonato Anormal (FARIN; PIEDRAHITA; FARIN, 2006). Dos animais que sobrevivem ao parto, muitos apresentam um fenótipo alterado e necessitam de atendimentos clínicos intensivos para se manter vivos na primeira semana de vida (MEIRELLES et al., 2010). Por estes distúrbios, esta síndrome têm se tornado importante também sob o ponto de vista ético em termos do bem-estar animal, comprometendo sua aplicabilidade comercial e científica (BERTOLINI et al., 2007).

A clonagem animal por transferência nuclear de célula somática (TNCS), apesar de conceitualmente simples, envolve múltiplas etapas que tornam o processo bastante complexo (CAMPBELL et al., 2005). A reprogramação do núcleo doador após a transferência nuclear é considerada uma das etapas vitais para o correto desenvolvimento embrionário posterior (CAMPBELL et al., 2007), com o núcleo doador tendo que ser reprogramado completamente e o citoplasto receptor incumbido de conduzir as reações de reprogramação iniciais (OBACK, 2008). A forma e o intervalo de ativação do complexo citoplasto-carioplasto, doador-receptor de núcleo, respectivamente, após a fusão, apresentam grande relevância para esta adequada reprogramação nuclear e para o reinício do ciclo celular (CAMPBELL et al., 2007). Todavia, este ponto crucial do processo permanece obscuro, com o intervalo fusão-ativação ainda por ser melhor definido e compreendido.

Uma das formas de se melhorar os resultados obtidos após a TNCS é aperfeiçoar as condições de cultivo utilizadas, incluindo a produção de quimeras pela agregação de embriões no momento do cultivo (BOIANI et al., 2003; MISICA-TURNER et al., 2007; RIBEIRO et al., 2009). Esta técnica já foi descrita anteriormente, como uma maneira de se minimizar os efeitos deletérios da heteroplasmia causada pela fusão de dois oócitos e uma célula de diferentes origens (VAJTA et al., 2005). Estes efeitos aditivos positivos da agregação já foram observados inclusive com influência direta no desenvolvimento in vivo posterior (BOIANI et al., 2003; PEDERSEN et al., 2005; MISICA-TURNER et al., 2007). Entretanto, 
uma melhor elucidação ainda é premente por razão de resultados conflitantes entre os grupos de pesquisa (TECIRLIOGLU et al., 2005).

As lacunas do conhecimento de cada etapa da TNCS ainda devem ser preenchidas, buscando uma melhora cumulativa de cada passo, e um processo de clonagem mais eficiente como um todo em seu final. Sendo assim, este trabalho visou determinar o efeito de dois distintos intervalos de fusão-ativaçao (duas e quatro horas) e da agregação de embriões bovinos clonados no desenvolvimento in vitro e in vivo subsequente.

\subsection{MATERIAL E MÉTODOS}

Todos os reagentes utilizados foram provenientes da Sigma-Aldrich Chemical Co. (St. Louis, MO, EUA), salvos os que são indicados à parte.

\subsubsection{Cultivo Celular de Células Somáticas}

Células somáticas de origem cutânea provenientes de uma fêmea bovina da raça Nelore registrada na Associação Brasileira de Criadores de Zebu (ABCZ) foram obtidas por explantação seguindo os procedimentos descritos por Gerger et al. (2010). Brevemente, uma biópsia auricular foi coletada de forma asséptica, imersa seqüencialmente por $20 \mathrm{~s}$ em álcool a $70^{\circ}$ GL e em uma solução de antibiótico-antimicótico (100X), lavada abundantemente em meio de cultivo, seccionada em fragmentos de 3 a $4 \mathrm{~mm}$ e dispostos em placas de cultivo celular de $35 \mathrm{~mm}$ (Corning Incorporated, NY, EUA), em número de 3 a 5 fragmentos por placa. Adicionou-se 0,8 mL de meio de cultivo (DMEM, Dulbecco's Modified Eagle's Medium, Gibco-BRL, NY, EUA), acrescido de 0,22 $\mathrm{mM}$ de piruvato de sódio, 26,2 $\mathrm{mM}$ de bicarbonato de sódio, $100 \mathrm{UI} / \mathrm{mL}$ de penicilina $\mathrm{G}, 100 \mu \mathrm{g} / \mathrm{mL}$ de sulfato de estreptomicina, $0,25 \mu \mathrm{g} / \mathrm{mL}$ de anfotericina B e 10\% de Soro Fetal Bovino (SFB, Gibco-BRL). O cultivo foi estabelecido, mantido e expandido em incubadora a $38,5^{\circ} \mathrm{C}$, com atmosfera controlada de $5 \%$ de $\mathrm{CO}_{2}$ em umidade saturada.

Partidas de células foram congeladas até no máximo a terceira passagem para uso nas rotinas de HMC. Brevemente, quando os cultivos atingiam confluência maior que $90 \%$, as 
células foram suspensas em uma solução de tripsina a $0,25 \%$ e $0,5 \mathrm{mM}$ de EDTA por 5 a 7 min e centrifugadas a $4000 \mathrm{~g}$ por $3 \mathrm{~min}$. A seguir, as células foram re-suspensas em meio de cultivo com $10 \%$ de dimetil sulfóxido (DMSO) e envasadas assepticamente em palhetas estéreis de $0,25 \mathrm{~mL}$ em volume aproximado de $150 \mu \mathrm{L}$, para uma concentração de $1 \times 10^{3}$ células $/ \mu \mathrm{L}$. As palhetas foram mantidas entre 2 a $4^{\circ} \mathrm{C}$ por 15 min e então expostas ao vapor de nitrogênio líquido $\left(\mathrm{N}_{2} \mathrm{~L}\right)$ a uma temperatura entre -80 a $-110^{\circ} \mathrm{C}$ por $5 \mathrm{~min}$, sendo imersas em $\mathrm{N}_{2} \mathrm{~L}$ e estocadas em botijão criogênico para uso posterior. A descongelação foi realizada $72 \mathrm{~h}$ antes da utilização na rotina de clonagem por $\mathrm{HMC}$, por imersão em água a $36^{\circ} \mathrm{C}$ por $30 \mathrm{~s}$, seguido do cultivo em placa de cultivo celular de 4-poços (Nunclon ${ }^{\circledR} 144444$, Nunc, Roskilde, Dinamarca), pela diluição direta do volume de cada palheta em $500 \mu \mathrm{L}$ de meio de cultivo por poço, visando obter uma confluência elevada (>95\%) 24 h antes de sua utilização (GERGER et al., 2010). Aproximadamente $6 \mathrm{~h}$ após a semeadura das células descongeladas, realizava-se a troca do meio de cultivo para a remoção de células mortas e de remanescentes do meio de congelação.

\subsubsection{Produção In Vitro de Embriões por Transferência Nuclear de Célula Somática e por Partenogênese}

A produção in vitro (PIV) de embriões por TNCS foi realizada utilizando a metodologia do Handmade Cloning (HMC) ou clonagem manual, desenvolvida por Vajta et al. (2003) e modificada de acordo com Ribeiro et al. (2009) e Gerger et al. (2010), conforme abaixo. Os procedimentos de maturação in vitro (MIV) de oócitos e de cultivo in vitro (CIV) de embriões foram conduzidos em placas de cultivo celular de 4-poços.

Maturação in vitro (MIV) - Os Complexos cumulus-oócito (CCOs) aspirados de ovários bovinos coletados de três frigoríficos regionais foram morfologicamente selecionados em Graus 1, 2 e 3 segundo a classificação de Gonçalves, Figueiredo e Freitas (2008) e submetidos à MIV por 17 h, em meio M199 composto por TCM-199 (M2520), suplementado com 26,2 mM de $\mathrm{NaHCO}_{3}, 0,2 \mathrm{mM}$ de piruvato de sódio, $0,5 \mu \mathrm{g} / \mathrm{mL}$ de FSH (Folltropin ${ }^{\circledR}-\mathrm{V}$, Bioniche Animal Health Inc., Canadá), $5 \mu \mathrm{g} / \mathrm{mL}$ de LH (Lutropin ${ }^{\circledR}-\mathrm{V}$, Bioniche Animal Health Inc., Canadá) e 10\% de Soro de Égua em Estro inativado (SEE), em incubadora a $38,5^{\circ} \mathrm{C}, 5 \%$ de $\mathrm{CO}_{2}$ e umidade saturada. 
Transferência nuclear de células somática (TNCS) - As células do cumulus oophorus e da corona radiata foram removidas dos CCOs por pipetagem contínua em M199H composto por TCM-199 (M2520), suplementado com 2,4 mM de $\mathrm{NaHCO}_{3}, 2,0 \mathrm{mM}$ de piruvato de sódio e acrescido de 10\% de SFB. Em seguida, os oócitos maturos foram selecionados pela presença do $1^{\circ}$ corpúsculo polar, sob lupa estereomicroscópica. Destes, removeu-se a zona pelúcida (ZP) pela breve exposição a uma solução de protease (P-8811) a 0,5\% em M199H + 0,01\% de álcool polivinílico (PVA). Em seguida, os oócitos sem ZP foram incubados por 10 min em $5 \mu \mathrm{g} / \mathrm{mL}$ de citocalasina $\mathrm{B}(\mathrm{CCB}, \mathrm{C}-6762)$ em M199H + 10\% de SFB, e submetidos à bisecção manual, em grupos de 2 a 3 oócitos por microgotas de $5 \mu \mathrm{L}$ de meio com CCB, sob óleo mineral, utilizando-se uma lâmina de bisecção (Ultra-sharp Splitting Blade, Bioniche Inc., EUA), sob lupa estereomicroscópica. Após a bisecção, e seguindo-se a incubação em 10 $\mu \mathrm{g} / \mathrm{mL}$ de bisbenzimida (Hoechst 33342, B-2261) em M199H + SFB por $10 \mathrm{~min}$, os hemioócitos contendo aproximadamente $50 \%$ do volume citoplasmático original foram selecionados em um microscópio invertido de epifluorescência (XDY-1, China) com filtro UV em enucleados e nucleados, conforme a presença da placa metafásica. Os hemi-oócitos que continham a placa metafásica (hemi-carioplastos) foram lavados em M199 + 10\% SFB e reservados para posterior utilização na produção de embriões partenogenéticos. Os hemioócitos enucleados (hemi-citoplastos) foram lavados em M199H + 10\% SFB para uso na reconstrução embrionária.

As células doadoras de núcleo foram obtidas após a tripsinização de cultivos celulares em alta confluência (>95\%), sendo utilizadas para a reconstrução apenas células individualizadas de pequeno tamanho, arredondadas e com a membrana celular intacta, visando o aumento na proporção de células na fase G0/G1 do ciclo celular (BOQUEST; DAY; PRATHER, 1999). Os embriões foram reconstruídos com reconstituição de aproximadamente $100 \%$ do volume citoplasmático inicial (pré-fusão), onde dois hemicitoplastos foram dispostos linearmente com a célula somática doadora de núcleo em uma das extremidades. A adesão das estruturas ocorreu mediante a exposição a $500 \mu \mathrm{g} / \mathrm{mL}$ de fitohemaglutinina (PHA, L-8754) em M199H + PVA. As estruturas reconstruídas foram lavadas em M199H + SFB, equilibradas em meio de eletrofusão (EF) contendo 0,3 M de manitol, 0,05 mM de $\mathrm{CaCl}_{2} \cdot 2 \mathrm{H}_{2} \mathrm{O}, 0,1 \mathrm{mM}$ de $\mathrm{MgSO}_{4} \cdot 7 \mathrm{H}_{2} \mathrm{O}, 0,5 \mathrm{mM}$ de Hepes e $0,01 \%$ de PVA, para então serem distribuídas em uma câmara de fusão de $3,2 \mathrm{~mm}$ de espaço entre eletrodos (BTX 453, BTX Instruments, Genetronics, CA, EUA) contendo $650 \mu 1$ de meio EF, acoplada a um aparelho de eletrofusão (BTX Electro Cell Manipulator 200, Biotechnologies \& Experimental Research Inc., San Diego, CA, EUA). Os complexos reconstruídos foram 
submetidos a um pré-pulso de corrente alternada (AC) de $15 \mathrm{~V}$ por $5 \mathrm{~s}$ para a indução do alinhamento, seguido de dois pulsos elétricos de corrente contínua (DC) de $1,25 \mathrm{kV} / \mathrm{cm}$ por $20 \mu$ s para a fusão das membranas celulares.

As estruturas submetidas à fusão foram cultivadas individualmente, em microgotas de $5 \mu \mathrm{L}$ sob óleo, por 45 a 60 min em M199 + 10\% SFB, em incubadora a 38,5 $5^{\circ} \mathrm{C}, 5 \%$ de $\mathrm{CO}_{2} \mathrm{e}$ umidade saturada, para a avaliação da taxa de fusão. Os embriões fusionados e os grupos (partenotos) de oócitos com ZP intacta, sem ZP e de hemi-carioplastos foram separados de forma aleatória em dois grupos. O primeiro foi quimicamente ativado 2,0 $\pm 0,1 \mathrm{~h}$ após a fusão ( 2 hpf, 25,2 $\pm 1,0$ h após o começo da maturação), e o segundo com 4,0 $\pm 0,1 \mathrm{~h}$ de intervalo após a fusão (4 hpf, 27,2 $\pm 1,0$ h após o começo da maturação). Todas as estruturas de ambos os intervalos de fusão-ativação ( $2 \mathrm{hpf}$ ou $4 \mathrm{hpf}$ ) foram ativadas em $5 \mu \mathrm{M}$ de ionomicina (I0634) em M199H por 5 min, seguido da incubação individualizada em $5 \mu \mathrm{L}$ de M199 + SFB contendo $2 \mathrm{mM}$ de 6-dimetilaminopurina (6-DMAP, D-2629), sob óleo mineral, durante $4 \mathrm{~h}$.

Cultivo in vitro (CIV) e formação dos grupos experimentais - Embriões clonados e partenogeneticamente ativados foram submetidos ao CIV pelo sistema Well-of-the-Well (WOW), ou de micro-poços, de acordo com Vajta et al. (2000), e modificado por Feltrin et al. (2006). Os micro-poços foram confeccionados manualmente dentro de poços de placas 4poços contendo $400 \mu \mathrm{L}$ de meio SOFaaci (HOLM et al., 1999) suplementado com 0,34 mM de citrato tri-sódico, 2,77 $\mathrm{mM}$ de mio-inositol, $30 \mu \mathrm{L} / \mathrm{mL}$ de aminoácidos essenciais (BME B 6766) e $10 \mu \mathrm{L} / \mathrm{mL}$ de aminoácidos não essenciais (MEM - M 7145), acrescido de 5\% de SEE, $5 \mu \mathrm{g} / \mathrm{mL}$ de insulina, $5 \mu \mathrm{g} / \mathrm{mL}$ de transferrina e $5 \mathrm{ng} / \mathrm{mL}$ de selenito de sódio (ITS-X, I1884), sob óleo mineral. 


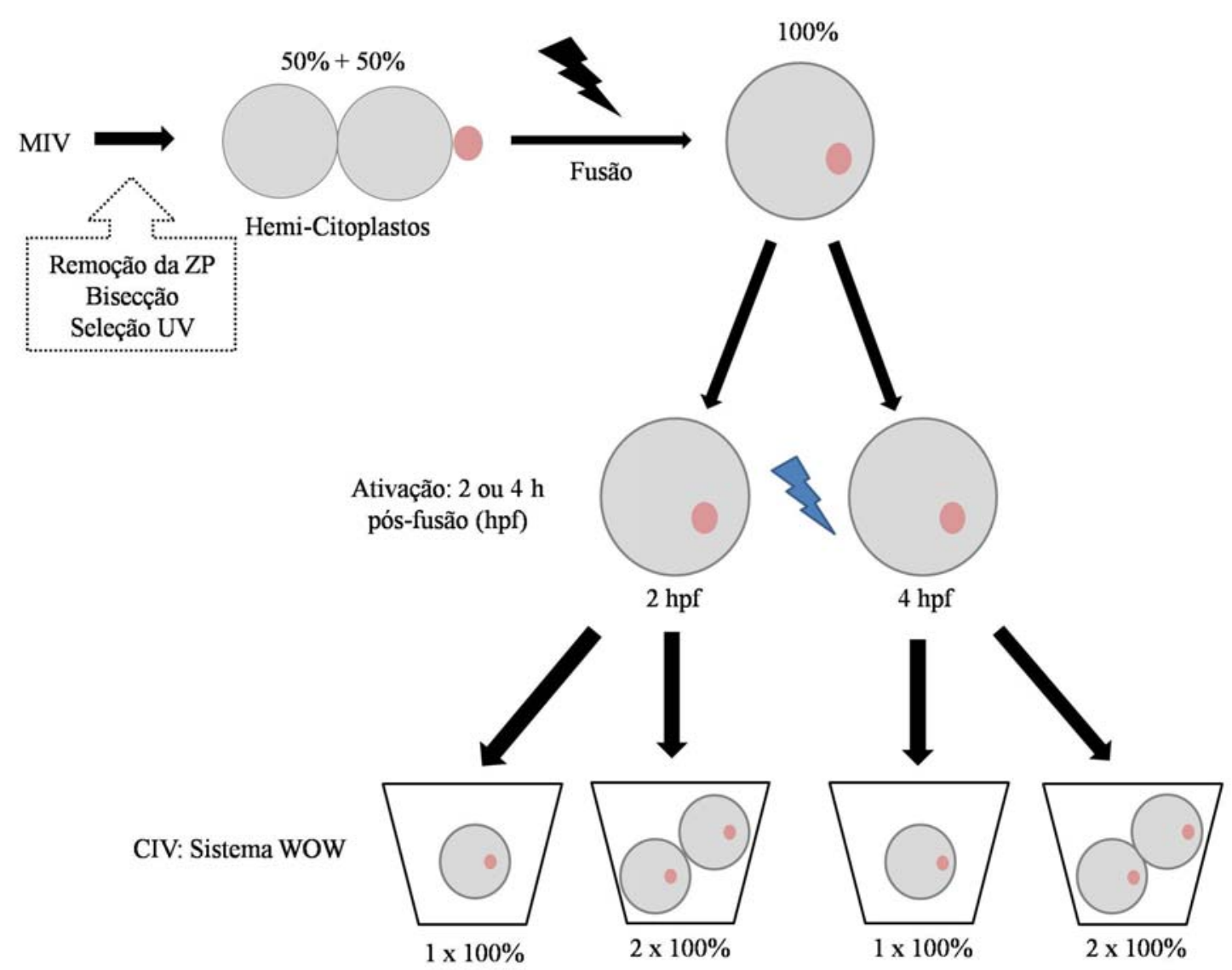

Figura 5.1 - Ilustração da produção e formação dos grupos experimentais de embriões clones utilizando a técnica do HMC e do sistema WOW de cultivo in vitro de embriões

Os presumíveis zigotos de ambos os intervalos de fusão-ativação ( 2 hpf ou 4 hpf) foram alocados nos micro-poços em duas disposições: 1 x 100\%, grupo formado pela alocação individual de um único zigoto dentro de um micro-poço, resultando em um volume citoplasmático final aproximado de 100\%; e 2 x 100\%, grupo formado pela agregação de dois zigotos em um único micro-poço, resultando em um volume citoplasmático final aproximado de $200 \%$, conforme ilustrado na figura 5.1. Da mesma forma, hemi-carioplastos (hemi-oócitos nucleados remanescentes da seleção por UV) foram segregados em dois grupos em ambos os intervalos de 2 hpf e 4 hpf: agregação de dois $(2 \times 50 \%)$ ou de quatro $(4 \times 50 \%)$ hemipartenotos por WOW, compondo aproximadamente $100 \%$ e $200 \%$ de volume final, respectivamente, por agregação. Por último, oócitos com ZP intacta (1 x 100\%, cZP) e oócitos sem ZP (1 x 100\%, sZP), para ambos os intervalos de fusão-ativação, foram dispostos individualmente em cada micro-poço. A disposição da formação dos grupos partenotos encontra-se ilustrada na figura 5.2. As placas de cultivo de embriões foram incubadas sob o sistema Foil Bag (VAJTA et al., 1997), com atmosfera de 5\% de $\mathrm{CO}_{2}, 5 \%$ de $\mathrm{O}_{2}$ e $90 \%$ de $\mathrm{N}_{2}$, 
a $38,5^{\circ} \mathrm{C}$ por $168 \mathrm{~h}$ (início da ativação = hora 0 ) até o estádio de blastocisto. Com $48 \mathrm{~h}$ de CIV realizou-se a avaliação da clivagem embrionária.

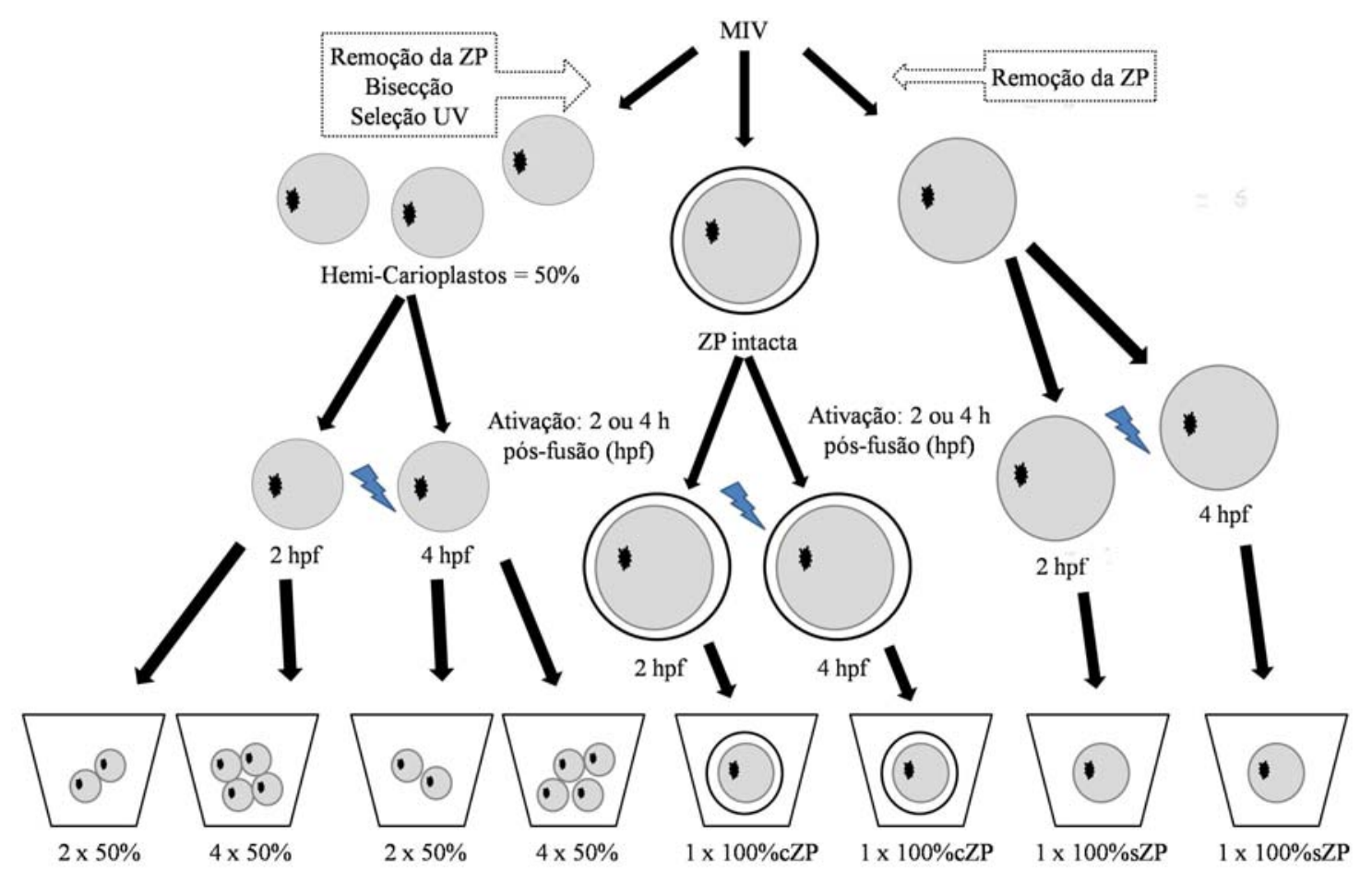

Figura 5.2 - Ilustração da produção e formação dos grupos experimentais de embriões partenotos utilizando a técnica do HMC e do sistema WOW de cultivo in vitro de embriões

\subsubsection{Viabilidade In Vivo}

Buscando-se avaliar a viabilidade in vivo dos embriões clonados, uma parcela dos blastocistos avaliados morfologicamente em Graus 1 e 2, seguindo a classificação do manual da IETS (STRINGFELLOW; SEIDEL, 1998), provenientes dos grupos 1 x 100\% e 2 x 100\% com $2 \mathrm{hpf}$ e $4 \mathrm{hpf}$ foram transferidos a fresco no dia 7 de desenvolvimento. As transferências para os quatro grupos ( $2 \mathrm{hpf} / 1 \times 100 \%$; $2 \mathrm{hpf} / 2 \times 100 \%$; $4 \mathrm{hpf} / 1 \times 100 \%$; e $4 \mathrm{hpf} / 2 \times 100 \%)$ foram aleatórias, com a transferência de um ou dois embriões por receptora por grupo. Os embriões foram transferidos pelo método não-cirúrgico para fêmeas receptoras síncronas no dia 7 do ciclo estral. As receptoras pertenciam ao rebanho de corte da Estação Experimental da Empresa de Pesquisa Agropecuária e Extensão Rural de Santa Catarina (Epagri/Lages), em Lages-SC, distante 10 min do laboratório. O transporte dos embriões ocorreu em M199H + 
$20 \% \mathrm{SFB}$, após envase em palhetas de $0,25 \mathrm{~mL}$, mantidas a uma temperatura média de $37^{\circ} \mathrm{C}$ até a transferência dos embriões por via cervical.

Os diagnósticos de gestação e do gênero fetal foram realizados aos 30 e 58 dias, respectivamente, por ultrasonografia transretal, utilizando-se um aparelho de ultrasonografia veterinário portátil em tempo real (100 Falco $^{\circledR}$ - Pie Medical) equipado com um transdutor linear de $5 \mathrm{MHz}$. A viabilidade fetal e presença de anormalidades nos conceptos durante as gestações foram acessadas semanalmente dos 30 aos 93 dias de prenhez. A partir de então, as prenhezes foram monitoradas por palpação retal com intervalos de duas semanas até o Dia 225 de desenvolvimento, quando foram utilizadas para o experimento do Capítulo 3.

\subsubsection{Análise Estatística}

Os dados qualitativos de clivagem, blastocisto, prenhez e de eficiência relativa, e os de freqüência de estádio e qualidade embrionários foram comparados pelo teste do $\chi^{2}$ ou teste de Fisher, para $\mathrm{p}<0,05$.

\subsection{RESULTADOS}

Um total de 4521 CCOs foi colocado em maturação in vitro, com 2410 (53,3\%) estruturas consideradas maturadas com a visualização da presença do $1^{\circ}$ corpúsculo polar $17 \mathrm{~h}$ do início da MIV. Após a remoção da zona pelúcida, bisecção manual e seleção por fluorescência, 52,5\% dos hemi-oócitos (1879/3579) foram considerados enucleados (hemicitoplastos), sendo utilizados para a reconstrução de 883 embriões (100\% do volume citoplasmático). Destes, 670 (75,9\%) fusionaram após estímulo elétrico, e foram utilizados para a formação dos grupos experimentais $1 \times 100 \%$ e $2 \times 100 \%$. Uma parte dos hemicarioplastos (hemi-oócitos com núcleo) foi utilizada em cada rotina para a formação de grupos de embriões partenotos agregados como 2 x 50\% e 4 x 50\%. 
Tabela 5.1 - Taxas de clivagem e blastocisto e eficiência relativa de produção embrionária para totais de CCOs iniciais e para embriões clones e partenotos reconstruídos por agregação com distintos volumes citoplasmáticos e intervalos de fusão-ativação, Laboratório de Reprodução Animal, UDESC - Lages, SC - 2008-2009

\begin{tabular}{|c|c|c|c|c|c|c|c|c|c|}
\hline \multirow{2}{*}{ Embrião } & \multirow{2}{*}{$\begin{array}{c}\text { Intervalo } \\
\text { fusão-ativação }\end{array}$} & \multirow{2}{*}{$\begin{array}{c}\text { Volume Citoplasmático } \\
\text { (agregação) }^{\ddagger}\end{array}$} & \multirow{2}{*}{$\mathbf{n}^{*}$} & \multicolumn{2}{|c|}{ Taxa de Clivagem* } & \multicolumn{2}{|c|}{ Taxa de Blastocisto* } & \multicolumn{2}{|c|}{ Eficiência Relativa $^{¥}$} \\
\hline & & & & $\mathbf{n}$ & $\%$ & $\mathbf{n}$ & $\%$ & Razão & $\%$ \\
\hline \multirow{4}{*}{ Clone } & \multirow{2}{*}{$2 \mathrm{hpf}$} & $1 \times 100 \%$ & 115 & 97 & $84,3^{b}$ & 31 & $27,0^{\mathrm{a}-\mathrm{d}}$ & $1: 23,3^{\mathrm{a}}$ & 4,3 \\
\hline & & $2 \times 100 \%$ & 106 & 104 & $98,1^{\mathrm{e}}$ & 46 & $43,4^{\mathrm{ef}}$ & $1: 14,5^{\mathrm{b}}$ & 6,9 \\
\hline & \multirow{2}{*}{$4 \mathrm{hpf}$} & $1 \times 100 \%$ & 112 & 72 & $64,3^{\mathrm{a}}$ & 40 & $35,7^{\mathrm{c}-\mathrm{f}}$ & $1: 17,6^{\mathrm{ab}}$ & 5,7 \\
\hline & & $2 \times 100 \%$ & 107 & 91 & $85,0^{\mathrm{b}}$ & 52 & $48,6^{\mathrm{f}}$ & $1: 12,9^{\mathrm{b}}$ & 7,7 \\
\hline \multirow{8}{*}{ Partenoto } & \multirow{4}{*}{$2 \mathrm{hpf}^{\S}$} & $2 \times 50 \%$ & 81 & 67 & $82,7^{b}$ & 13 & $16,0^{\mathrm{a}}$ & $\mathrm{n} / \mathrm{a}$ & $\mathrm{n} / \mathrm{a}$ \\
\hline & & $4 \times 50 \%$ & 80 & 69 & $86,3^{b}$ & 17 & $21,3^{a b}$ & $\mathrm{n} / \mathrm{a}$ & $\mathrm{n} / \mathrm{a}$ \\
\hline & & $1 \times 100 \%, \mathrm{cZP}$ & 82 & 72 & $87,8^{b c}$ & 27 & $32,9^{\mathrm{b}-\mathrm{e}}$ & $1: 5,7^{\mathrm{c}}$ & 17,6 \\
\hline & & $1 \times 100 \%, \mathrm{sZP}$ & 82 & 80 & $97,6^{\mathrm{de}}$ & 40 & $48,8^{\mathrm{f}}$ & $1: 3,9^{\mathrm{c}}$ & 25,5 \\
\hline & \multirow{4}{*}{$4 \mathrm{hpf}^{\S}$} & $2 \times 50 \%$ & 81 & 74 & $91,4^{b-d}$ & 19 & $23,5^{\mathrm{a}-\mathrm{c}}$ & $\mathrm{n} / \mathrm{a}$ & $\mathrm{n} / \mathrm{a}$ \\
\hline & & $4 \times 50 \%$ & 80 & 78 & $97,5^{\mathrm{de}}$ & 22 & $27,5^{\mathrm{a}-\mathrm{d}}$ & $\mathrm{n} / \mathrm{a}$ & $\mathrm{n} / \mathrm{a}$ \\
\hline & & $1 \times 100 \%, c Z P$ & 82 & 76 & $92,7^{\mathrm{b}-\mathrm{e}}$ & 32 & $39,0^{\mathrm{d}-\mathrm{f}}$ & $1: 4,8^{\mathrm{c}}$ & 20,8 \\
\hline & & $1 \times 100 \%, \mathrm{sZP}$ & 83 & 79 & $95,2^{\mathrm{c}-\mathrm{e}}$ & 41 & $49,4^{\mathrm{f}}$ & $1: 3,9^{c}$ & 25,8 \\
\hline
\end{tabular}

Agregação de embriões clones (100\%) ou hemi-partenotos (50\%)

*Baseando-se no número de micro-poços ou WOW

${ }^{\ddagger}$ Blastocistos por total de CCOs iniciais utilizados em cada grupo

${ }^{\text {a-f: }}$ Números com letras desiguais na coluna diferem, $\mathrm{P}<0,05$

${ }^{\S}$ Oócitos ativados partenogeneticamente concomitantes aos grupos de embriões clonados nos intervalos de 2 e $4 \mathrm{hpf}$

n/a: não aplicável 


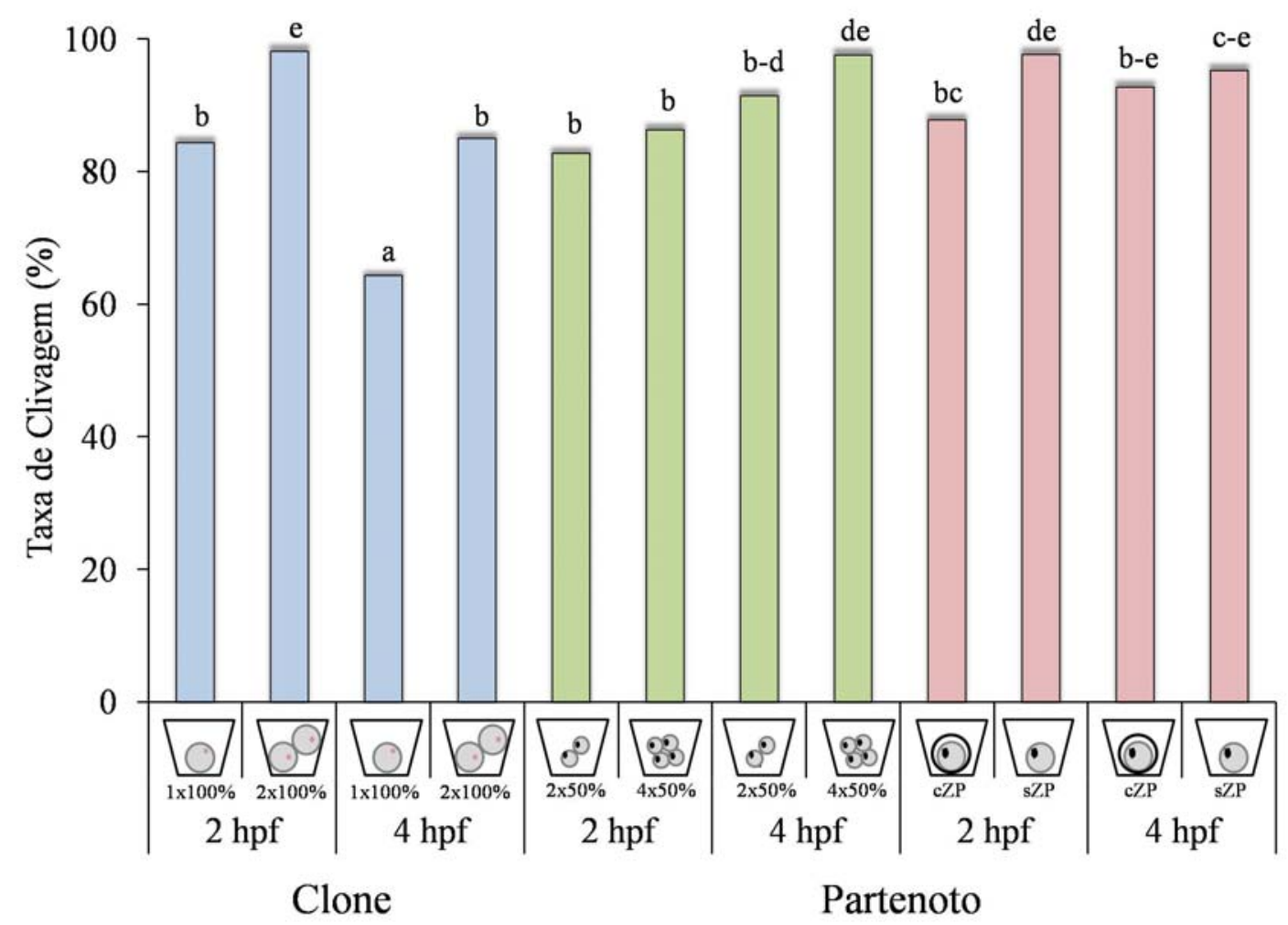

Figura 5.3 - Taxas de clivagem (\%) para embriões clones e partenotos bovinos reconstruídos por agregação, com distintos volumes citoplasmáticos e intervalos de fusão-ativação. ${ }^{\text {a-e: }}$ Colunas com sobrescritos desiguais diferem, $\mathrm{P}<0,05$

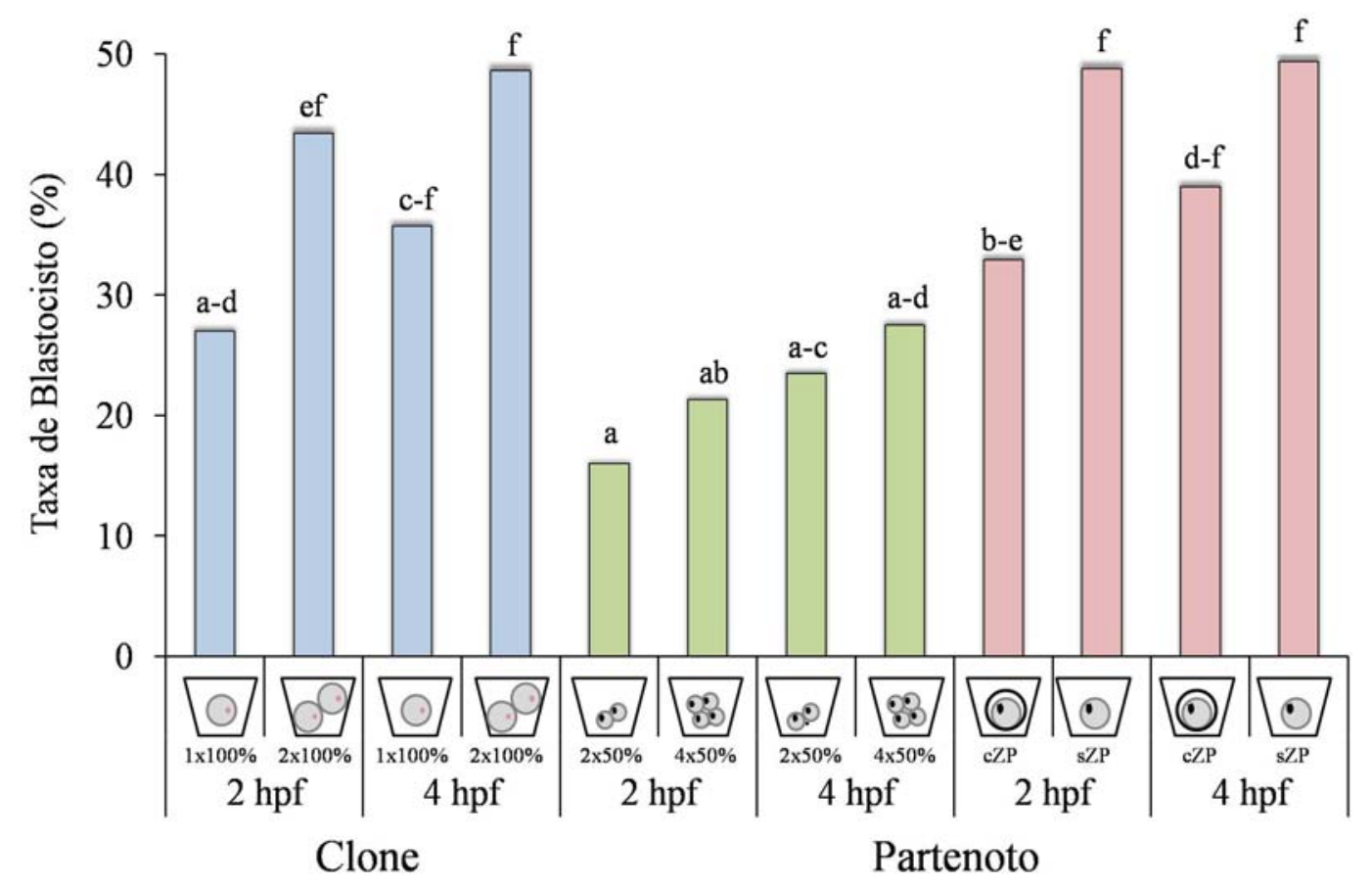

Figura 5.4 - Taxas de blastocisto (\%) para embriões clones e partenotos bovinos reconstruídos por agregação,

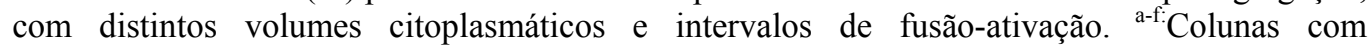
sobrescritos desiguais diferem, $\mathrm{P}<0,05$ 
Conforme os dados apresentados na tabela 5.1 e ilustrado na figura 5.3, a taxa de clivagem do grupo clone $4 \mathrm{hpf} / 1$ x 100\% foi significativamente menor que a de todos os outros grupos. Em compensação, este grupo apresentou um desenvolvimento a blastocisto significativo, já que esta taxa, baseando-se na clivagem, foi a segunda maior $(55,6 \%)$ entre os grupos, sendo a primeira a do grupo $4 \mathrm{hpf} / 2 \times 100 \%$ com 57,1\%. A taxa de blastocisto para o grupo $2 \mathrm{hpf} / 1 \mathrm{x}$ 100\% foi menor do que a dos clones agregados em ambos os intervalos de fusão-ativação, conforme ilustrado na figura 5.4.

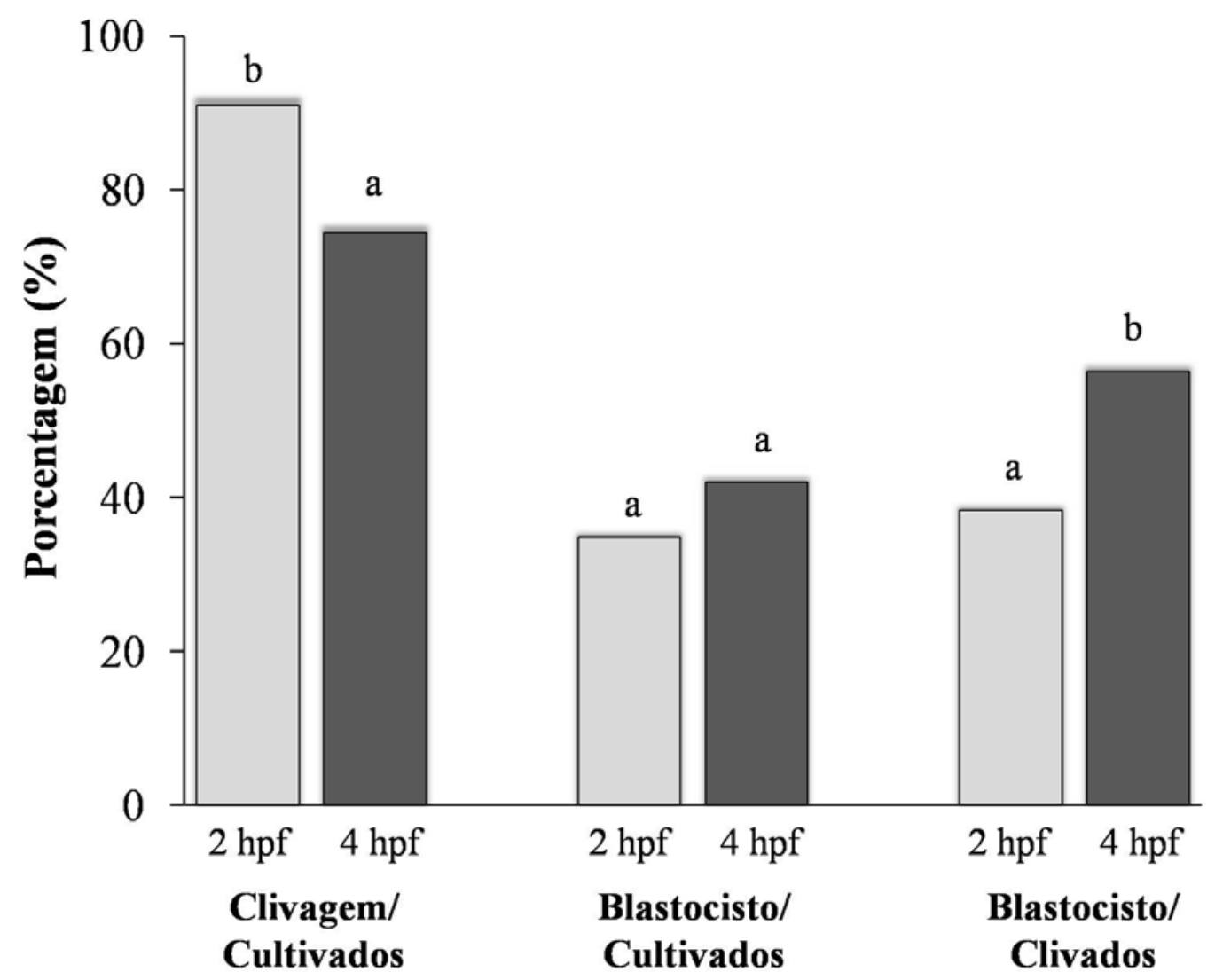

Figura 5.5 - Taxas de clivagem e blastocisto baseadas nos embriões cultivados, e de blastocisto baseada nos clivados (\%) para embriões clones, ativados com intervalos de fusão-ativação de 2 (2 hpf) ou 4 (4 hpf) horas, independente do esquema de agregação. ${ }^{\text {a-b: }}$ Dentro de cada taxa, colunas com sobrescritos desiguais diferem, $\mathrm{P}<0,05$

Quando observado apenas o intervalo de ativação, conforme ilustrado na figura 5.5 entre os clones ( 2 hpf vs. 4 hpf), independente da agregação, o grupo de 2 hpf apresentou uma maior taxa de clivagem $(91,0 \%$ vs. $74,4 \%)$; entretanto, a produção de blastocistos, que foi similar quando baseado nas estruturas cultivadas $(34,8 \%$ vs. $42,0 \%)$, aumentou significativamente para o intervalo de 4 hpf quando baseou-se a taxa de blastocisto na taxa de clivagem, ou número de estruturas clivadas (38,3\% vs. 56,4\%). 


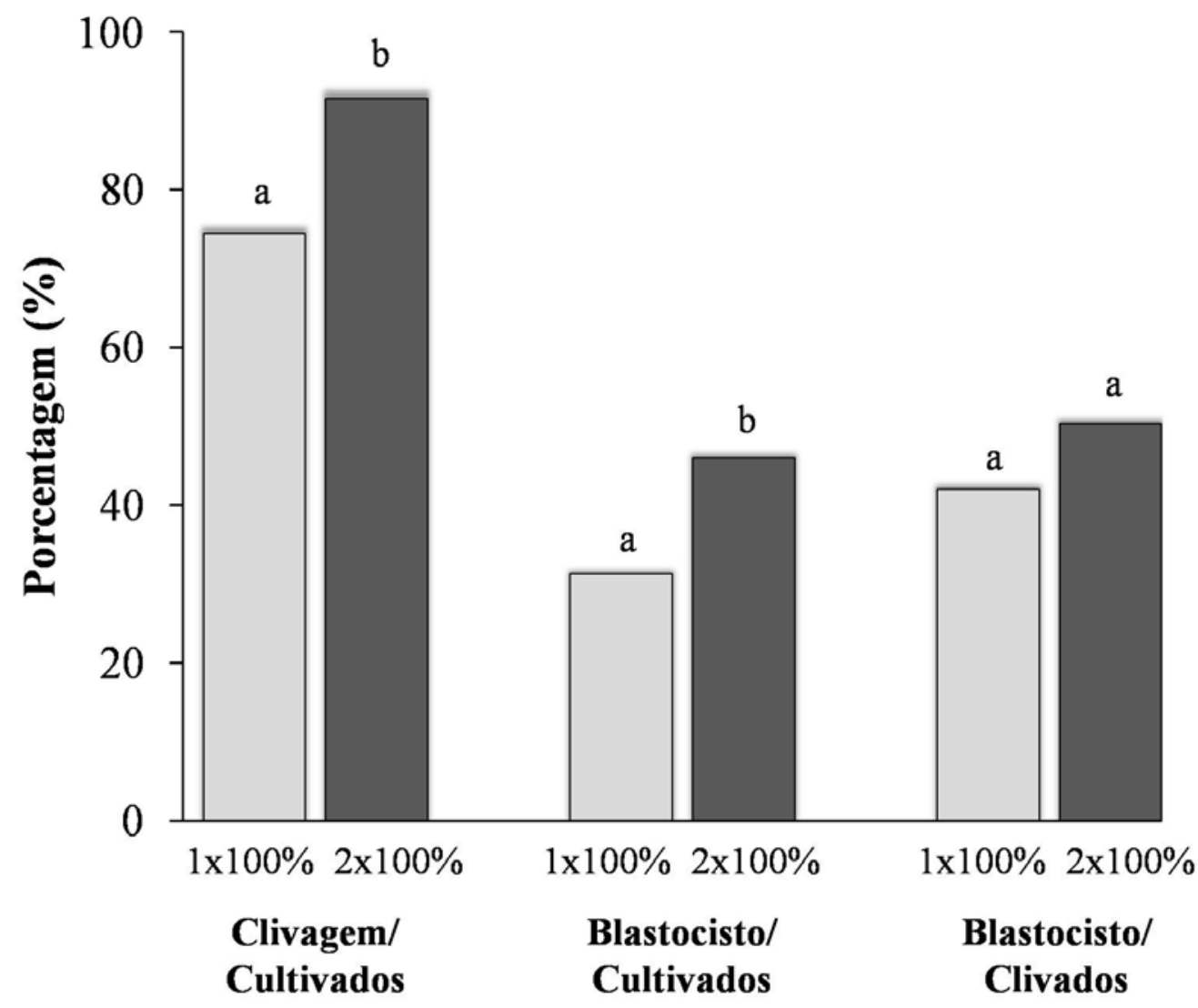

Figura 5.6 - Taxas de clivagem e blastocisto baseadas nos embriões cultivados, e de blastocisto baseada nos clivados (\%) para embriões clones, agregados ( 2 x 100\%) ou não (1 x 100\%), independente do intervalo de fusão-ativação. ${ }^{\text {a-b: }}$ Dentro de cada taxa, colunas com sobrescritos desiguais diferem, $\mathrm{P}<0,05$

A agregação de clones ( 1 x 100\% vs. 2 x 100\%), independente do intervalo de ativação utilizado (Figura 5.6), determinou um incremento na clivagem (74,4\% vs. 91,5\%) e produção de blastocistos (31,3\% vs. 46,0\%). Apesar do aumento das taxas de clivagem e blastocisto com a agregação de dois embriões por micro-poço, quando estas taxas foram calculadas baseando-se no número de embriões colocados em cultivo, tanto a clivagem $(45,8 \%)$ quanto a produção de blastocistos $(23,0 \%)$ reduziram em $50 \%$ e significativamente no grupo agregado $2 \times 100 \%$, que utilizou dois embriões por micro-poço no momento do cultivo, enquanto que as taxas do grupo sem agregação permaneceram inalteradas $(74,4 \% \mathrm{e}$ $31,3 \%$, clivagem e blastocisto, respectivamente), pela utilização de apenas uma estrutura por micro-poço.

Conforme observado na tabela 5.1, a eficiência de produção dos partenotos foi similar entre os grupos e significativamente superior a todos os grupos de embriões clonados. Dentre os grupos de clones, a eficiência geral média, baseando-se no número de micro-poços e de 
embriões colocados em cultivo, foi de $6,1 \%$ e 4,1\%, respectivamente, com 1 embrião produzido para cada 16 e 24 CCOs iniciais. A eficiência dos agregados ( 2 x 100\%) em ambos os intervalos de ativação foi semelhante e superior ao grupo $2 \mathrm{hpf} / 1$ x 100\%, mas não diferiu do grupo $4 \mathrm{hpf} / 1$ x 100\%, que por sua vez foram semelhantes.

O intervalo fusão-ativação, independente do esquema de agregação, não apresentou influência na eficiência de produção de blastocistos. Porém, a eficiência na produção de blastocistos pela agregação de dois embriões $100 \%$ ao cultivo individual de embriões $1 \mathrm{x}$ $100 \%$ (7,3\% vs. 5,0\%, ou 98/1337 vs. 71/1425, respectivamente), independente do intervalo fusão-ativação, foi significativamente superior. Entretanto, esta eficiência se inverte quando se calcula esta taxa baseando-se no número de embriões colocados em cultivo, com a eficiência de produção de blastocisto neste grupo reduzida pela metade $(3,66 \%, 98 / 2674)$ e significativamente inferior ao grupo sem agregação, com a produção de um blastocisto para cada 20 e 27 CCOs, para os grupos 1 x 100\% e 2 x 100\%, respectivamente.

Dentre os partenotos, apesar do grupo $4 \mathrm{hpf} / 4 \times 50 \%$ apresentar uma maior taxa de clivagem do que os partenotos 2 x 50\% e 4 × 50\% ativados mais precocemente ( 2 hpf), as taxas de clivagem e blastocisto para os partenotos 2 × 50\% e 4 × 50\% não diferiram entre si, independente do esquema de agregação ou do intervalo de ativação. $\mathrm{O}$ aumento do intervalo de ativação (4 hpf), independente da agregação, elevou a taxa de clivagem (84,5\% vs. 94,4\%), mas não a de blastocisto no dia 7 (18,6\% vs. 25,5\%), nem na de blastocisto baseada na clivagem (22,1\% vs. 27,0\%). O aumento no número de hemi-embriões partenotos agregados (de $2 \times 50 \%$ para 4 × 50\%), independente da ativação, não alterou as taxas de desenvolvimento $(87,0 \%$ vs. $91,9 \% ; 19,8 \%$ vs. $24,4 \%$ e $22,7 \%$ vs. $26,5 \%$ para clivagem, blastocisto e blastocisto/clivagem, respectivamente).

Nos partenotos $1 \times 100 \%$, a remoção da ZP aumentou significativamente as taxas de clivagem $(90,2 \%$ vs. $96,4 \%)$ e de blastocisto (36,0 vs. 49,1\%), independentemente do intervalo fusão-ativação utilizado. O intervalo de ativação ( 2 hpf vs. 4 hpf), independente da remoção da ZP, não afetou o desenvolvimento posterior para qualquer dos dois grupos.

A avaliação da freqüência de desenvolvimento dos embriões produzidos não demonstrou haverem diferenças expressivas quanto ao estádio e qualidade observados em blastocistos produzidos nos quatro grupos de clones, conforme apresentado na tabela 5.2. Todos os grupos apresentaram, em geral, mais de $75 \%$ dos embriões nos estádios mais avançados de desenvolvimento, especificamente, blastocisto expandido e eclodindo/eclodido (estádios 7 e 8/9, respectivamente). Da mesma forma, todos os grupos apresentaram uma boa qualidade embrionária, com mais de $50 \%$ dos embriões classificados em grau 1 , e mais de 
$85 \%$ em graus 1 e 2 (ótima e boa, respectivamente). O intervalo fusão-ativação, independente da agregação, e o esquema de agregação, independente da fusão-ativação, não interferiram na cinética de desenvolvimento ou na qualidade embrionária, com a freqüência sendo similar em cada estádio e grau. O grupo que apresentou a maior proporção de embriões com o maior desenvolvimento (estádio 8/9) e melhor qualidade (grau 1) foi o com intervalo de 4 hpf e cultivo de um embrião 100\% individual (4 hpf/1 x 100\%), com probabilidade de 43,7\% ( $0,583 \times 0,750$, para estádio e qualidade, respectivamente) de ocorrência após cultivo in vitro. 
Tabela 5.2 - Distribuição da freqüência relativa quanto a estádio e qualidade para embriões clones produzidos com distintos intervalos de fusão-ativação (2 hpf ou 4 hpf) e esquemas de agregação (1 x 100\% ou 2 x 100\%), Laboratório de Reprodução Animal, UDESC - Lages, SC - 2008-2009

\begin{tabular}{|c|c|c|c|c|c|c|c|c|}
\hline \multirow{2}{*}{$\begin{array}{c}\text { Intervalo } \\
\text { fusão-ativação }\end{array}$} & \multirow{2}{*}{$\begin{array}{c}\text { Volume } \\
\text { Citoplasmático } \\
\text { (agregação) }\end{array}$} & \multicolumn{4}{|c|}{ Estádio de Desenvolvimento Embrionário* } & \multicolumn{3}{|c|}{ Qualidade Embrionária ${ }^{€}$} \\
\hline & & 5 & 6 & 7 & $8 / 9$ & Grau 1 & Grau 2 & Grau 3 \\
\hline \multirow{3}{*}{$2 \mathrm{hpf}$} & $1 \times 100 \%$ & $0,037^{\mathrm{Aa}}$ & $0,074^{\mathrm{Aab}}$ & $0,407^{\mathrm{Bab}}$ & $0,481^{\mathrm{Ba}-\mathrm{c}}$ & $0,593^{\mathrm{Ba}-\mathrm{c}}$ & $0,296^{\mathrm{Aab}}$ & $0,111^{\mathrm{Ab}}$ \\
\hline & & & & & & & & \\
\hline & $2 \times 100 \%$ & $0,000^{\mathrm{Aa}}$ & $0,143^{\text {Aa-c }}$ & $0,500^{\mathrm{Bb}}$ & $0,357^{\mathrm{Ba}}$ & $0,500^{\mathrm{Ba}}$ & $0,452^{\mathrm{Bb}}$ & $0,048^{\mathrm{Ab}}$ \\
\hline \multirow{2}{*}{$4 \mathrm{hpf}$} & $1 \times 100 \%$ & $0,000^{\mathrm{Aa}}$ & $0,056^{\mathrm{Aa}}$ & $0,361^{\mathrm{Bab}}$ & $0,583^{\mathrm{Cc}}$ & $0,750^{\mathrm{Cc}}$ & $0,250^{\mathrm{Ba}}$ & $0,000^{\mathrm{Aa}}$ \\
\hline & $2 \times 100 \%$ & $0,020^{\mathrm{Aa}}$ & $0,260^{\mathrm{Bc}}$ & $0,300^{\mathrm{BCa}}$ & $0,420^{\mathrm{Ca}-\mathrm{c}}$ & $0,580^{\mathrm{Cab}}$ & $0,300^{\mathrm{Bab}}$ & $0,120^{\mathrm{Ab}}$ \\
\hline $2 \mathrm{hpf}$ & $¥$ & $0,014^{\mathrm{Aa}}$ & $0,116^{\mathrm{Bab}}$ & $0,464^{\mathrm{Cab}}$ & $0,406^{\mathrm{Cab}}$ & $0,536^{\mathrm{Bab}}$ & $0,391^{\mathrm{Bab}}$ & $0,072^{\mathrm{Ab}}$ \\
\hline $4 \mathrm{hpf}$ & $¥$ & $0,012^{\mathrm{Aa}}$ & $0,174^{\mathrm{Ba}-\mathrm{c}}$ & $0,326^{\mathrm{Ca}}$ & $0,488^{\mathrm{Da}-\mathrm{c}}$ & $0,651^{\mathrm{Ca}-\mathrm{c}}$ & $0,279^{\mathrm{Bab}}$ & $0,070^{\mathrm{Ab}}$ \\
\hline$\dagger$ & $1 \times 100 \%$ & $0,016^{\mathrm{Aa}}$ & $0,063^{\mathrm{Aa}}$ & $0,381^{\mathrm{Bab}}$ & $0,540^{\mathrm{Bbc}}$ & $0,683^{\mathrm{Cbc}}$ & $0,270^{\mathrm{Ba}}$ & $0,048^{\mathrm{Ab}}$ \\
\hline$\dagger$ & $2 \times 100 \%$ & $0,011^{\mathrm{Aa}}$ & $0,207^{\mathrm{Bbc}}$ & $0,391^{\mathrm{Cab}}$ & $0,391^{\mathrm{Cab}}$ & $0,543^{\mathrm{Cab}}$ & $0,370^{\mathrm{Bab}}$ & $0,087^{\mathrm{Ab}}$ \\
\hline
\end{tabular}

*Estádio 5, blastocisto inicial; Estádio 6, blastocisto; Estádio 7, blastocisto expandido; Estádios 8/9, blastocistos em eclosão ou eclodidos

${ }^{€}$ Grau 1, ótima; Grau 2, boa; Grau 3, ruim

${ }^{\sharp}$ Independente do esquema de agregação

Independente do intervalo de fusão-ativação

A-D:Dados na mesma linha, para estádio de desenvolvimento ou qualidade embrionária, sem o mesmo sobrescrito, diferem, $\mathrm{P}<0,05$

a-c: Dados na mesma coluna sem o mesmo sobrescrito, diferem, $\mathrm{P}<0,05$ 
Tabela 5.3 - Taxas de prenhez após a transferência de embriões bovinos clonados com intervalos fusão-ativação de 2 ou 4 h pós-fusão (hpf) e cultivados in vitro individualmente (1 x 100\%) ou agregados (2 x 100\%), EPAGRI - Lages, SC - 2008-2009

\begin{tabular}{|c|c|c|c|c|c|c|c|c|c|c|c|c|c|c|c|c|}
\hline \multirow{3}{*}{$\begin{array}{c}\text { Tempo } \\
\text { de } \\
\text { ativação }\end{array}$} & \multirow{3}{*}{ Agregação } & \multirow{3}{*}{$\begin{array}{l}\text { Embriões } \\
\text { por } \\
\text { receptora }\end{array}$} & \multirow{3}{*}{$\underset{\mathbf{n}}{\text { Receptoras }}$} & \multirow{3}{*}{$\begin{array}{c}\text { Embriões } \\
\text { transferidos } \\
\mathbf{n}\end{array}$} & \multicolumn{12}{|c|}{ Prenhez } \\
\hline & & & & & \multicolumn{2}{|c|}{ Dia 30} & \multicolumn{2}{|c|}{ Dia 37} & \multicolumn{2}{|c|}{ Dia 44} & \multicolumn{2}{|c|}{ Dia 51} & \multicolumn{2}{|c|}{ Dia 58} & \multicolumn{2}{|c|}{ Dia 225} \\
\hline & & & & & $\mathbf{n}$ & $\%$ & $\mathbf{n}$ & $\%$ & $\mathbf{n}$ & $\%$ & n & $\%$ & $\mathbf{n}$ & $\%$ & $\mathbf{n}$ & $\%$ \\
\hline \multirow{6}{*}{$2 \mathrm{hpf}$} & \multirow{3}{*}{$1 \times 100 \%$} & 1 & 9 & 9 & 2 & 22,2 & 2 & 22,2 & 0 & 0,0 & 0 & 0,0 & 0 & 0,0 & 0 & 0,0 \\
\hline & & 2 & 5 & 10 & 2 & 40,0 & 1 & 20,0 & 1 & 20,0 & 1 & 20,0 & 1 & 20,0 & 1 & 20,0 \\
\hline & & Sub-total & 14 & 19 & 4 & 28,6 & 3 & 21,4 & 1 & 7,1 & 1 & 7,1 & 1 & 7,1 & 1 & 7,1 \\
\hline & \multirow{3}{*}{$2 \times 100 \%$} & 1 & 11 & 11 & 5 & 45,5 & 2 & 18,2 & 2 & 18,2 & 0 & 0,0 & 0 & 0,0 & 0 & 0,0 \\
\hline & & 2 & 5 & 10 & 3 & 60,0 & 2 & 40,0 & 2 & 40,0 & 1 & 20,0 & 1 & 20,0 & 1 & 20,0 \\
\hline & & Sub-total & 16 & 21 & 8 & 50,0 & 4 & 25,0 & 4 & 25,0 & 1 & 6,3 & 1 & 6,3 & 1 & 6,3 \\
\hline \multirow{6}{*}{$4 \mathrm{hpf}$} & \multirow{3}{*}{$1 \times 100 \%$} & 1 & 10 & 10 & 4 & 40,0 & 3 & 30,0 & 3 & 30,0 & 3 & 30,0 & 3 & 30,0 & 3 & 30,0 \\
\hline & & 2 & 5 & 10 & 2 & 40,0 & 1 & 20,0 & 1 & 20,0 & 1 & 20,0 & 0 & 0,0 & 0 & 0,0 \\
\hline & & Sub-total & 15 & 20 & 6 & 40,0 & 4 & 26,7 & 4 & 26,7 & 4 & 26,7 & 3 & 20,0 & 3 & 20,0 \\
\hline & \multirow{3}{*}{$2 \times 100 \%$} & 1 & 10 & 10 & 3 & 30,0 & 1 & 10,0 & 1 & 10,0 & 0 & 0,0 & 0 & 0,0 & 0 & 0,0 \\
\hline & & 2 & 5 & 10 & 3 & 60,0 & 1 & 20,0 & 1 & 20,0 & 1 & 20,0 & 1 & 20,0 & 0 & 0,0 \\
\hline & & Sub-total & 15 & 20 & 6 & 40,0 & 2 & 13,3 & 2 & 13,3 & 1 & 6,7 & 1 & 6,7 & 0 & 0,0 \\
\hline - & - & Total & 60 & 80 & 24 & 40,0 & 13 & 21,7 & 11 & 18,3 & 7 & 11,7 & 6 & 10,0 & 5 & 8,3 \\
\hline
\end{tabular}




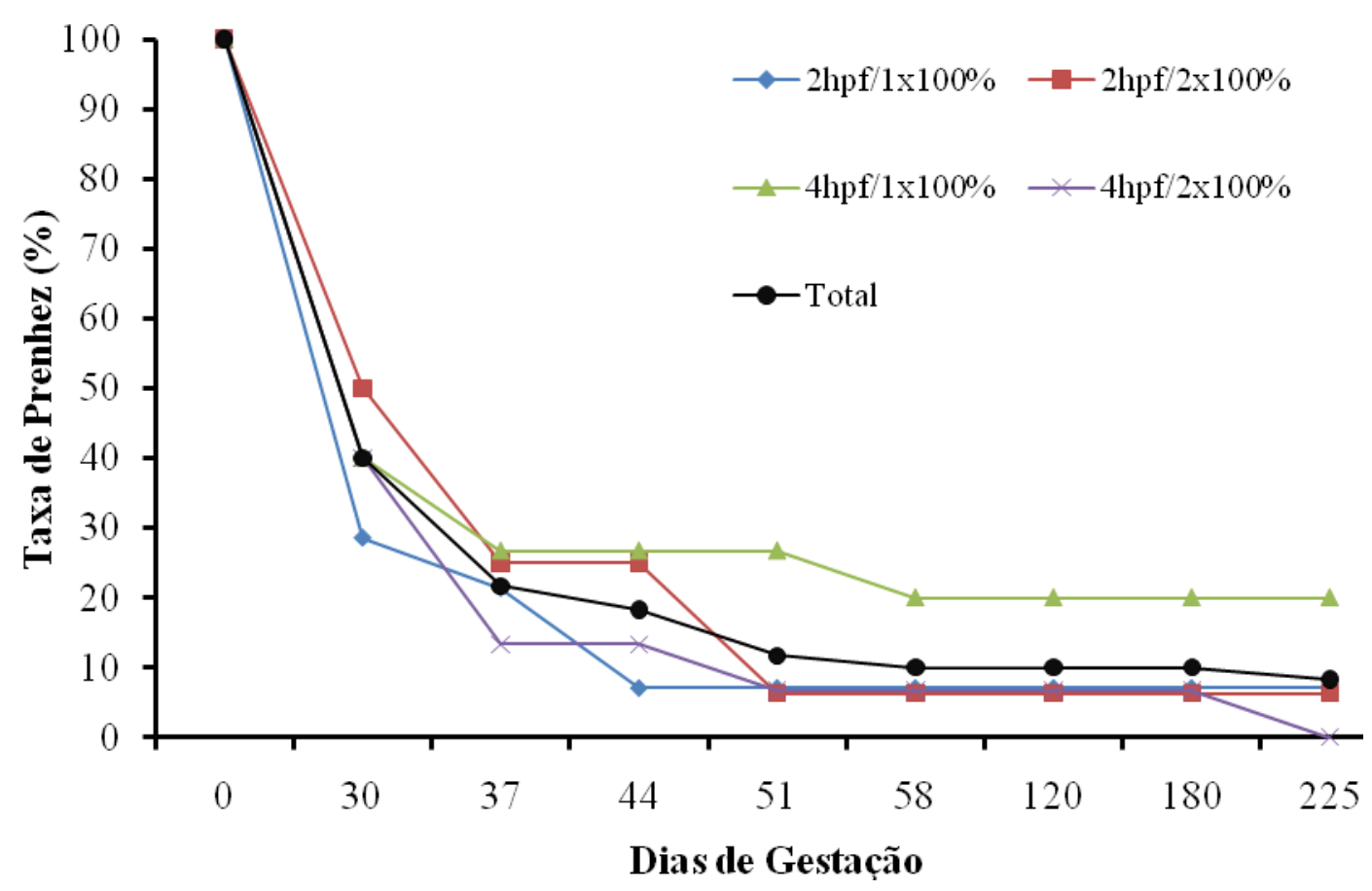

Figura 5.7 - Taxas de prenhez e manutenção da gestação até o dia 225 (\%) para embriões bovinos clonados submetidos a dois intervalos de fusão-ativação ( $2 \mathrm{hpf} v \mathrm{~s} .4 \mathrm{hpf}$ ) e dois esquemas de cultivo in vitro ( 1 x $100 \%$ vs. $2 \times 100 \%)$

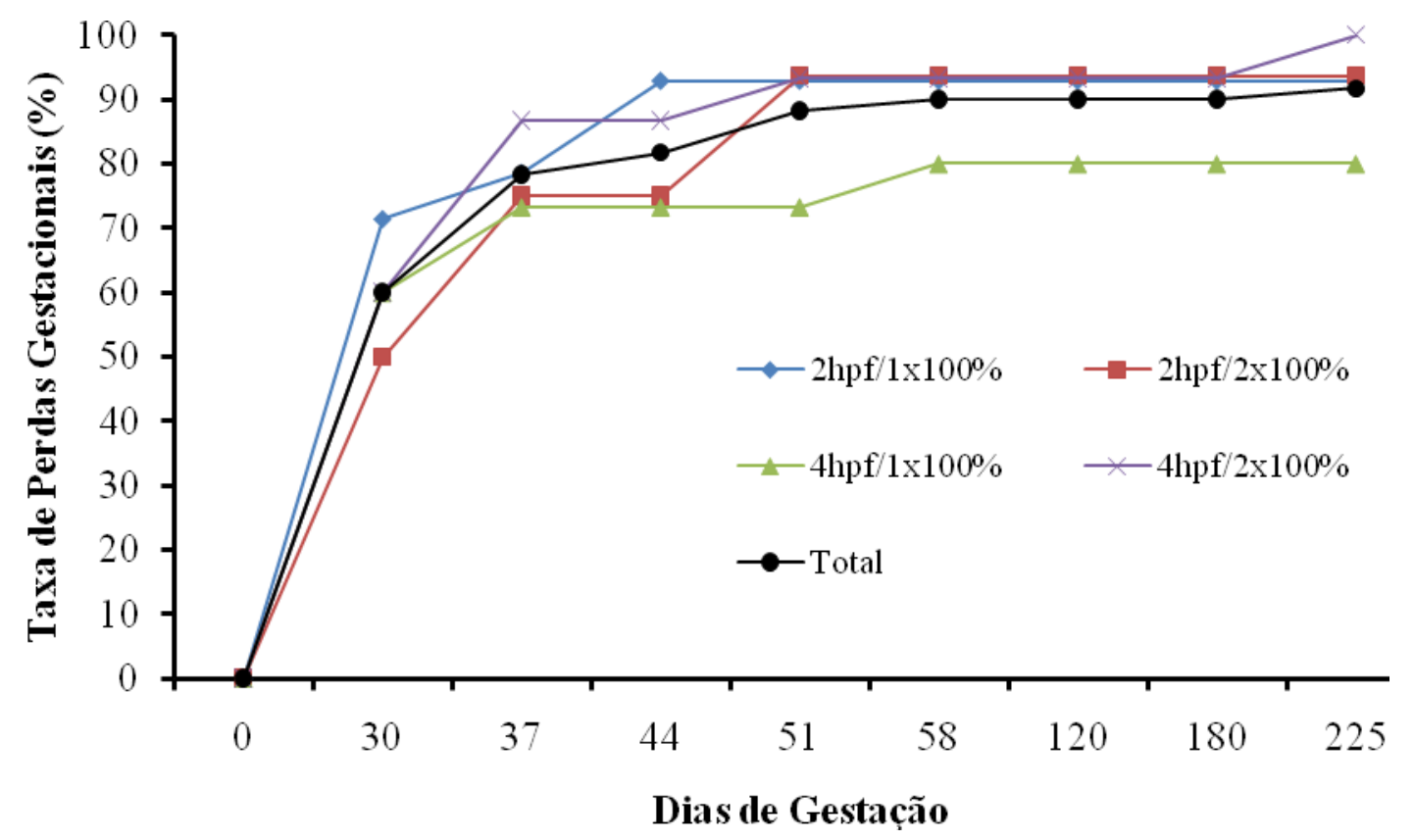

Figura 5.8 - Taxas de perdas gestacionais (\%) para embriões bovinos clonados submetidos a dois intervalos de fusão-ativação ( 2 hpf vs. 4 hpf) e dois esquemas de cultivo in vitro (1 x 100\% vs. 2 x 100\%) até o dia 225 de gestação 
A viabilidade embrionária in vivo foi avaliada após a transferência de embriões clonados dos grupos 2 hpf e 4 hpf, agregados ou não ( 2 x 100\% vs. 1 x 100\%), para fêmeas receptoras síncronas. As taxas de prenhez foram semelhantes em todos os períodos observados, conforme apresentado na tabela 5.3 e evidenciado nas figuras 5.7 e 5.8. A taxa média de prenhez foi de 40,0\% (24/60), com perdas gestacionais acumuladas de 54,2\% (13/24), 75,0\% (18/24) e 75,0\% (18/24) para os intervalos de 30-44, 44-58 e 58-180 dias de prenhez, respectivamente. Não houve influência do intervalo fusão-ativação ou do esquema de agregação nas taxas de desenvolvimento in vivo posterior.

A eficiência relativa total para o estabelecimento de prenhezes aos 30 dias de gestação, quando avaliada com base no número de CCOs iniciais utilizados, foi de $0,87 \%$ (1 prenhez para cada 115 CCOs iniciais), sendo a eficiência para cada grupo de $0,55 \%$ (1:180), $1,20 \%(1: 83), 0,85 \%(1: 117)$ e 0,89\% (1:112) para os grupos $2 \mathrm{hpf} / 1 \times 100 \%, 2 \mathrm{hpf} / 2 \mathrm{x}$ $100 \%, 4 \mathrm{hpf} / 1 \times 100 \%$ e $4 \mathrm{hpf} / 2 \times 100 \%$, respectivamente. A eficiência de prenhez total aos 30 dias, baseando-se no número em embriões colocados em cultivo (653) e na quantidade de WOWs (440) foi de 3,7\% (1:27) e 5,5\% (1:18), respectivamente. Aos 225 dias, com apenas 5 prenhezes viáveis, esta eficiência passou para $0,8 \%$ (1:131) e 1,1\% (1:88) para o número de embriões em cultivo e quantidade de WOWs, respectivamente.

A transferência de um ou de dois embriões por receptora não influenciou as taxas de prenhez ou de perdas gestacionais, com apenas duas fêmeas gestando gêmeos após a transferência de dois embriões, ambas do grupo 4 hpf/2 x 100\%. Uma destas fêmeas abortou entre os dias 30 e 35 de prenhez, com a outra abortando aos 196 dias de gestação. As outras cinco prenhezes foram encerradas eletivamente aos 225 dias de gestação para a coleta de material biológico para o experimento do Capítulo 3.

\subsection{DISCUSSÃO}

O sucesso na produção in vitro de embriões clonados por TNCS depende da eficiência das diversas etapas intrínsecas ao processo (CAMPBELL et al., 2005), com fatores técnicos e biológicos apresentando influência direta ou indireta no grau de reprogramação do genoma após a TNCS, e que podem repercutir em conseqüências nem sempre favoráveis ao desenvolvimento embrionário e fetal posterior. Estudos anteriores, incluindo o do nosso grupo de pesquisa, demonstraram que o aumento ou diminuição do volume citoplasmático podem 
afetar significativamente o futuro desenvolvimento embrionário, com tal alteração de volume podendo ser realizada por fusão de citoplastos com diferentes volumes ou pela agregação de hemi-embriões (50\% do volume inicial) e/ou embriões (100\% do volume) clonados (PEURA; LEWIS; TROUNSON, 1998; BOIANI et al., 2003; PEDERSEN et al., 2005; TECIRLIOGLU et al., 2005; MISICA-TURNER et al., 2007; RIBEIRO et al., 2009).

Neste estudo, o aumento nas taxas de clivagem e de blastocisto observado quando o volume citoplasmático final foi duplicado pela agregação de embriões ( 2 x 100\%), corrobora com os resultados de Tecirlioglu et al. (2005) e de Ribeiro et al. (2009). Entretanto, este estudo não demonstrou um aumento linear nas taxas de clivagem $(91,5 \%$ vs. 74,4\% para embriões 2 × 100\% vs. 1 x 100\%, respectivamente) e produção de blastocistos (46,0\% vs. $31,3 \%$, respectivamente), baseando-se em total de micro-poços utilizados, conforme o observado anteriormente em clones pela agregação de hemi-embriões bovinos (RIBEIRO et al., 2009) ou embriões murinos em estádios de 4- a 8-células (BOIANI et al., 2003). Interessantemente, quando o número de embriões empregados em cultivo é utilizado para comparar as taxas entre a agregação ou não de embriões ( 2 x 100\% vs. 1 x 100\%), a agregação demonstrou uma redução significativa na eficiência, baseando-se na clivagem (45,8\% vs. $74,4 \%$, respectivamente) e no desenvolvimento até o estádio de blastocisto $(23,0 \%$ vs. $31,3 \%$, respectivamente), com uma redução da eficiência geral do processo, pela agregação, de 7,3\% para 3,7\%. Em nosso experimento prévio (RIBEIRO et al., 2009), todavia, verificou-se um efeito aditivo no potencial de desenvolvimento embrionário nos mesmos grupos de embriões clones cultivados in vitro ( 2 x 100\% e 1 x 100\%), havendo um aumento não linear significativo das taxas de clivagem (96,8\% vs. 76,9\%, respectivamente) e de blastocisto $(63,7 \%$ vs. $22,1 \%$, respectivamente), demonstrando um aumento na eficiência geral da clonagem. Esta melhora observada naquele experimento, além de ser demonstrada de forma qualitativa, pôde também ser verificada com a melhora do desenvolvimento, com a agregação ( 2 x 100\%) promovendo um aumento na freqüência de embriões com maior número total de células, em estádios de desenvolvimento mais avançados e com melhor qualidade morfológica. Este efeito aditivo no desenvolvimento também já foi observado por outros pesquisadores (BOIANI et al., 2003; PEDERSEN et al., 2005; TECIRLIOGLU et al., 2005; MISICA-TURNER et al., 2007), inclusive com efeitos benéficos diretos no desenvolvimento in vivo subseqüente (BOIANI et al., 2003; PEDERSEN et al., 2005; MISICA-TURNER et al., 2007).

O resultado oposto ao esperado, observado pela agregação embrionária neste estudo com a redução da eficiência da clonagem com a agregação de embriões, deve-se 
provavelmente não tão somente a uma diminuição do desenvolvimento dos agregados no dia 7 per se, mas também às melhores taxas obtidas com o grupo 1 x 100\% em ambos os intervalos de ativação neste experimento, em especial com a taxa de blastocisto, que foi significativamente maior (31,3\% vs. 22,1\%) quando comparada ao do experimento de Ribeiro et al. (2009). Esta observação sugere que a agregação embrionária deva ser empregada mais eficientemente e recomendada na clonagem de bovinos quando as condições de produção in vitro de embriões forem sub-ótimas, quando a qualidade oocitária estiver reduzida ou quando as taxas de blastocisto forem próximas ou inferiores a $20 \%$. Esta premissa tem por base o fato de que a agregação de embriões pode aumentar a eficiência na clonagem, não somente por permitir um desenvolvimento de blastocistos com maior número de células, mas também por potencialmente influenciar a alocação celular nas linhagens embrionárias, favorecendo o desenvolvimento placentário subsequente (VAJTA et al., 2005), por eliminar blastômeros com menor capacidade de desenvolvimento (VIUFF et al., 2002) e/ou por compensar defeitos epigenéticos presentes em alguns blastômeros, mas que podem ser corrigidos ou regulados de forma parácrina entre células adjacentes (BOIANI et al., 2003). Portanto, quando o desenvolvimento de embriões cultivados individualmente ( 1 x 100\%) é adequado (próximo ou superior a 30\%), os efeitos acima são minimizados ou anulados, diminuindo a vantagem da agregação, que somente resultaria em uma maior eficiência quando certas condições inerentes à produção de embriões forem menos favoráveis ao desenvolvimento como um todo.

Além do volume citoplasmático, a ativação do presumível zigoto parece constituir-se em uma etapa de vital importância para uma reprogramação nuclear adequada. Atualmente, a grande maioria dos laboratórios no mundo reconstrói embriões clonados com citoplastos receptores produzidos pela enucleação de oócitos estagnados em Metáfase na segunda divisão meiótica (MII), fundindo-os a células doadoras de núcleo preferentemente nas fases G0 ou G1 do ciclo celular (CAMPBELL et al., 2005). Acredita-se que o potencial de desenvolvimento esteja em seu pico máximo quando do uso de oócitos em MII, pelo citoplasma conter proteínas, RNA mensageiro (mRNA) e precursores moleculares acumulados durante a foliculogênese, componentes necessários para o desenvolvimento inicial até a ativação do genoma embrionário (PEURA; LEWIS; TROUNSON, 1998; ALBERIO; CAMPBELL; JOHNSON, 2006; GAO et al., 2007). Além destes constituintes, o oócito nesta fase contém uma elevada concentração de maturation promoting factor (MPF), uma cinase ciclinadependente que promove uma série de eventos considerados de elevada importância para a reprogramação adequada do material genético, incluindo a ruptura da vesícula germinativa e a conseguinte exposição do núcleo aos componentes do citoplasma receptor (CAMPBELL et 
al., 2005). Como o oócito receptor executa papel fundamental na reprogramação do núcleo doador após a TNCS (CAMPBELL et al., 2007), o intervalo fusão-ativação normalmente é tido como um período de fundamental importância na reprogramação, sendo supostamente mais eficiente quando mais prolongado (WILMUT et al., 1997). A contrapartida do aumento neste intervalo é a potencial redução da viabilidade das estruturas à medida do tempo por "envelhecimento" (CHIAN et al., 1992; PARK et al., 2005). As taxas de clivagem e blastocisto dos partenotos 1 x 100\% ativados nos grupos $2 \mathrm{hpf}$ ou $4 \mathrm{hpf}$, independente da remoção da ZP, não diferiram. Aliás, estas taxas foram muito semelhantes, com $92,7 \%$ vs. 93,9\%, e 40,9\% vs. 44,2\%, para clivagem e blastocisto, respectivamente. Estes valores provam que a viabilidade oocitária foi mantida tanto com $25 \pm 1,0 \mathrm{~h}$ (intervalo de $2 \mathrm{hpf}$ ) quanto com $27 \pm 1,0$ h (intervalo de 4 hpf) após o começo da maturação, demonstrando que não ocorreu um "envelhecimento" do oócito, e por conseguinte, uma perda de qualidade/viabilidade, fenômeno este já apresentado por outros pesquisadores (CHIAN et al., 1992; PARK et al., 2005).

Neste trabalho, quando observado apenas o intervalo fusão-ativação entre os clones (2 hpf vs. 4 hpf), independente da agregação, o grupo de 2 hpf apresentou uma maior taxa de clivagem. Entretanto, a produção de blastocistos que foi similar entre os grupos, aumentou significativamente para o intervalo de 4 hpf quando baseado na clivagem (38,3\% vs. 56,4\%). Este crescimento compensatório dos embriões do grupo 4 hpf após a ativação do genoma embrionário, que em bovinos acontece no estádio de 8 a 16 células (ROBL; STICE, 1989), provavelmente se deva a uma melhor reprogramação do genoma embrionário, visto que a exposição mais prolongada do núcleo doador aos fatores citoplasmáticos, desde a fusão até a ativação, é presentemente vista por vários autores como benéfica ao processo de reprogramação do genoma doador, devendo o intervalo entre a fusão e ativação ser de 4 a 6 horas (CAMPBELL et al., 1996; WELLS; MISICA; TERVIT, 1999; WRENZYCKI et al., 2001; VAJTA et al., 2003, 2005). Vajta et al. (2005) preconiza uma redução deste tempo para 3 a 4 h quando da ativação de embriões sem ZP. Porém, contrário a esta linha de pensamento, o desenvolvimento embrionário in vitro e mesmo in vivo também é possível pela utilização de citoplastos enucleados para a reconstrução de clones somente após a inativação do MPF pela pré-ativação oocitária (BORDIGNON; SMITH, 1998; KUROSAKA et al., 2002;) ou após a ativação espermática pela FIV (SCHURMANN; WELLS; OBACK, 2006; EGLI et al., 2007; MEZZALIRA, 2009), demonstrando que os efeitos do MPF no núcleo e cromatina da célula doadora (ruptura do envelope nuclear, condensação prematura da cromatina, etc.) não são essenciais para a reprogramação adequada do genoma doador. Percebe-se, portanto, que o 
período de tempo ideal necessário para permitir o início da reprogramação do genoma permanece indefinido e controvertido, em concordância a afirmações de Campbell (2002).

Os possíveis efeitos positivos da agregação observados no aumento da porcentagem de embriões em estádios mais desenvolvidos e com melhor qualidade, já demonstrados em outros estudos incluindo os nossos (BOIANI et al., 2003; PEDERSEN et al., 2005; TECIRLIOGLU et al., 2005; MISICA-TURNER et al., 2007; RIBEIRO et al., 2009), não foram observados neste experimento. Da mesma forma, não se observou influência do intervalo fusão-ativação utilizado. Aparentemente, estas diferenças de volume ( 1 x 100\% vs. 2 x 100\%) e de ativação dos embriões ( 2 hpf vs. 4 hph) não foram suficientes para promover uma diferença entre os grupos no que concerne estas taxas de comparação.

As taxas de clivagem e blastocisto nos grupos controles por partenogênese 1 x 100\% com e sem ZP demonstraram a viabilidade dos oócitos utilizados em cada procedimento, e apresentaram resultados semelhantes aos grupos com embriões clonados. De forma interessante, a remoção da zona pelúcida nestes partenotos (1 x 100\%), independente do intervalo fusão-ativação empregado, aumentou as taxas de desenvolvimento e apresentou um aumento numérico da eficiência de produção de blastocistos, mesmo que não significativo. Este incremento, possivelmente, deve ter ocorrido por uma seleção positiva/benéfica dos oócitos de melhor qualidade, que sobreviveram à exposição da protease no momento da remoção da ZP, aumentando a proporção de oócitos com menor competência ou qualidade no grupo com ZP intacta, reduzindo o desenvolvimento posterior neste grupo. Esta melhora nas taxas de desenvolvimento com a remoção da ZP já havia sido observada em estudos anteriores de nosso grupo (MEZZALIRA, 2009). Entretanto, o aumento naquele trabalho não foi significativo, podendo ter se revelado para este estudo por uma seleção mais criteriosa dos oócitos após a remoção da ZP, com a eliminação das estruturas que apresentavam um citoplasma mais heterogêneo e de baixa qualidade, o que promoveria um aumento no número de oócitos de melhor qualidade, e como conseqüência, um melhor desenvolvimento posterior no grupo sem ZP. Outra possibilidade, descrita recentemente por Li, Vajta e Callesen (2010), mas com a utilização de oócitos suínos, é a de que a presença da zona pelúcida pode comprometer o desenvolvimento embrionário posterior sob determinadas condições de cultivo in vitro, como a utilização do sistema WOW. Li, Vajta e Callesen (2010) observaram que oócitos suínos, após a ativação e cultivados no sistema WOW sem a presença da ZP apresentaram um melhor desenvolvimento e um maior número de células do que os oócitos com ZP sob as mesmas condições de cultivo. 
A utilização de partenotos oriundos de hemi-carioplastos, ao invés dos partenotos $1 \mathrm{x}$ $100 \%$, pode ser mais fidedigna para retratar as condições in vitro do procedimento de produção de embriões por TNCS até o seu final, visto que tais estruturas podem servir como controle da manipulação por haverem passado pelas mesmas etapas e condições de maturação, remoção da ZP, bisecção, exposição à luz UV, ativação e de cultivo, que os embriões clonados (RIBEIRO et al., 2009). Em nosso estudo anterior, a produção de blastocistos foi igual entre os grupos clones e partenotos com volumes semelhantes (RIBEIRO et al., 2009). Esta observação não se revelou verdadeira para este experimento, já que as taxas de blastocisto para os grupos partenotos (4 x 50\%) em ambos os intervalos de ativação foram significativamente menores do que as taxas dos grupos clones (2 x 100\%). Da mesma forma, independente do intervalo fusão-ativação, a produção de blastocistos nos grupos clones $(1 \times 100 \%$ e $2 \times 100 \%)$ foi superior aos respectivos grupos partenotos com volumes citoplasmáticos totais semelhantes $(2 \times 50 \%$ e 4 x 50\%). Esta redução nas taxas de blastocisto dos partenotos, talvez possa ser explicada por um maior tempo de exposição do material genético presente nos hemi-carioplastos à luz UV, por exemplo, o que certamente acarreta em um efeito deletério, promovendo uma redução na viabilidade posterior de hemicarioplastos, conforme observado no nosso e no trabalho de outros grupos de pesquisa, mas em zigotos (TSUNODA et al., 1988; SMITH, 1993; MEZZALIRA, 2009). De maneira semelhante aos grupos com embriões clonados, o aumento do intervalo de ativação (4 hpf) e da agregação de hemi-carioplastos (4 x 50\%) apresentou uma melhora numérica nas taxas de clivagem e blastocisto, mas não significativa. Baseando-se na agregação, este aumento se explica por uma maior probabilidade de quatro hemi-carioplastos apresentarem um maior número de estruturas clivadas e de blastocistos do que apenas duas estruturas por micro-poço. Baseando-se na ativação, talvez um maior intervalo em incubação antes da ativação seja benéfico para a reorganização do arcabouço citoplasmático após a bisecção do oócito. Estas observações devem ser mais bem estudadas no futuro.

As taxas de prenhez foram semelhantes entre os quatro grupos de embriões bovinos clonados, variando de $28,6 \%$ a 50,0\%, com uma taxa média de 40,0\% aos trinta dias de gestação, similares às taxas obtidas por Batchelder et al. (2005) e Panarace et al. (2007). As perdas gestacionais acumuladas até o dia 58 de gestação foram expressivas e totalizaram $75 \%$ das prenhezes iniciais. Entretanto, esta porcentagem também foi obtida por distintos grupos de pesquisa e comerciais (WELLS; MISICA; TERVIT, 1999; HILL et al., 2000; HEYMAN et al., 2002; BATCHELDER et al., 2005; PANARACE et al., 2007) e aparenta estar dentro da "normalidade" ou "aceitabilidade" obtida com embriões produzidos por TNCS. Com 225 dias 
de gestação, das vinte e quatro prenhezes iniciais, apenas cinco ( $8,3 \%$ das transferências) mantinham os fetos viáveis, obtendo-se um total de 79,3\% de perdas acumuladas no início do terceiro trimestre.

De forma interessante, a agregação de embriões, dependente ou independente do intervalo fusão-ativação empregado neste experimento, não influenciou no desenvolvimento in vivo posterior, o que corrobora com os achados de alguns pesquisadores (TECIRLIOGLU et al., 2005), mas divergindo de outros (BOIANI et al., 2003; PEDERSEN et al., 2005; MISICA-TURNER et al., 2007). Da mesma maneira, o intervalo fusão-ativação também não apresentou influência nas taxas de prenhez ou nas perdas gestacionais decorrentes. Ainda, não ocorreram diferenças na eficiência do estabelecimento ou manutenção de prenhezes. Todavia, baseando-se na elegante discussão de Hansen et al. (2010), a dificuldade de se averiguar uma real diferença entre dois tratamentos de cultivo ou produção in vitro de embriões, com possível efeito no desenvolvimento in vivo posterior, baseia-se no número mínimo de transferências necessário por grupo, visando aumentar o poder da análise estatística. Segundo estes pesquisadores (HANSEN et al., 2010), um número mínimo ideal de receptoras por grupo, para que diferenças apareçam em 70\% das vezes, seria de 300 animais por grupo, o que está muito além da capacidade e possibilidade de muitos grupos de pesquisa, incluindo o nosso, sendo provavelmente a causa da ausência de diferenças entre grupos experimentais neste estudo. Esta dificuldade, no entanto, já foi abordada por outros autores (TECIRLIOGLU et al., 2005), não sendo exclusivo para este estudo.

Em síntese, buscando melhorar a reprogramação nuclear de embriões produzidos por TNCS com efeitos diretos no desenvolvimento in vitro e in vivo posterior, este estudo verificou que um maior intervalo fusão-ativação (4 hpf) dos presumíveis zigotos, e que a agregação de embriões $(2 \times 100 \%)$ no cultivo in vitro podem propiciar melhores taxas de desenvolvimento a blastocisto baseando-se no número de micro-poços utilizados. No entanto, estas variáveis não apresentaram influência na probabilidade de produção de embriões de melhor qualidade ou de maior potencial in vitro de desenvolvimento, tampouco interferindo nas taxas de prenhez ou de manutenção das prenhezes após a transferência para receptoras. 
CAPÍTULO 3 COMPARAÇÃO MORFOLÓGICA, MORFOMÉTRICA E FISIOLÓGICA DE CONCEPTOS BOVINOS PRODUZIDOS IN VIVO, IN VITRO POR FECUNDAÇÃO E IN VITRO POR TRANSFERÊNCIA NUCLEAR ${ }^{3}$

\footnotetext{
${ }^{3}$ Artigo a ser submetido para a revista Reproduction
} 


\section{INTRODUÇÃO}

A produção in vitro (PIV) de embriões bovinos por fecundação in vitro (FIV) ou transferência nuclear de célula somática (TNCS) está associada a elevadas perdas gestacionais e a alterações morfofisiológicas dos conceptos, que se revelam em todas as fases gestacionais, com especial evidência no primeiro e terceiro trimestres (BERTOLINI et al., 2007). Em estudos anteriores, observou-se que o crescimento fetal de conceptos oriundos de FIV e TNCS foi caracterizado por um padrão bifásico de crescimento, com um período de retardo na fase que coincide com o início da placentação. Este fenômeno foi seguido por um desvio de desenvolvimento do tecido placentário em prenhezes FIV (BERTOLINI et al., 2002a, 2004) e TNCS (BATCHELDER et al., 2007a), restaurando o tamanho do feto no final do primeiro trimestre da prenhez (BERTOLINI et al., 2004). Tal manifestação culmina com a ocorrência de um maior tamanho e pesos uterinos, placentários e fetais no terceiro trimestre da gestação, com alterações morfológicas significativas em placentas de FIV e TNCS e o nascimento de bezerros absolutamente grandes com menor sobrevida pós-natal (BERTOLINI; ANDERSON, 2002; BERTOLINI et al., 2002a, 2004; BATCHELDER et al., 2007a).

Tais alterações morfológicas também foram correlacionadas ao maior acúmulo de glicose e frutose no plasma e fluidos fetais em prenhezes de FIV. Uma porção substancial da função placentária está relacionada à regulação e à transferência materno-fetal de nutrientes ao feto (FERRELL, 1989), com a maioria dos metabólitos transferidos por meio da placenta sendo metabolizados e/ou produzidos pelo tecido placentário (FERRELL, 1989). O excessivo padrão de crescimento fetal observado no final da gestação de embriões PIV parece estar associado a um aumento no aporte de substratos energéticos aos tecidos útero-placentáriofetais, em especial a glicose (BERTOLINI et al., 2004). Como a massa placentária torna-se maior em prenhezes de FIV e TNCS, uma maior utilização ou aporte de glicose e frutose parece ocorrer, reduzindo a restrição placentária e favorecendo o crescimento fetal.

$\mathrm{O}$ reduzido número de trabalhos comparando o desenvolvimento de conceptos em distintas fases da gestação dificulta a compreensão destas alterações. Como a taxa de crescimento de fetos bovinos atinge o seu máximo no início do terço final da gestação, próximo aos 225 dias (ELEY et al., 1978), a avaliação morfofisiológica dos componentes maternos e fetais neste momento, em gestações normais produzidas in vivo e em gestações produzidas in vitro, normalmente com desvios de normalidade, tende a ressaltar as alterações de um sistema que atinge sua máxima atividade, como a placenta, nesta fase. Ainda, com a 
utilização de dois grupos in vitro (FIV e TNCS), certas características ou anormalidades observadas em prenhezes FIV servem como controle tanto para o grupo controle quanto para os desvios ainda mais exacerbados no grupo TNCS, permitindo identificar com menor conflito quais distúrbios são agravados pelo processo de transferência nuclear per se, e quais são inerentes à produção in vitro de embriões. Sendo assim, o objetivo deste trabalho foi o de comparar o desenvolvimento de gestações produzidas in vivo (Controle), in vitro por fecundação (FIV) e in vitro por transferência nuclear de célula somática (TNCS), no terço inicial com o auxílio da ultasonografia, e aos 225 dias com a coleta dos úteros gravídicos e análise morfológica, morfométrica e bioquímica de conceptos nos três grupos experimentais.

\subsection{MATERIAL E MÉTODOS}

Todos os reagentes utilizados foram provenientes da Sigma-Aldrich Chemical Co. (St. Louis, MO, EUA), salvos os que são indicados à parte.

\subsubsection{Cultivo Celular de Células Somáticas}

Cultivos celulares primários foram estabelecidos a partir de biópsias assepticamente coletadas da orelha de uma fêmea bovina da raça Nelore adulta, seguindo os procedimentos descritos por Gerger et al. (2010). Brevemente, após a coleta, tecidos da orelha foram fragmentados e dispostos em placas de cultivo celular contendo meio de cultivo (DMEM, Dulbecco's Modified Eagle's Medium, Gibco-BRL, NY, EUA), acrescido de 0,22 mM de piruvato de sódio, 26,2 $\mathrm{mM}$ de bicarbonato de sódio, $100 \mathrm{UI} / \mathrm{mL}$ de penicilina $\mathrm{G}, 100 \mu \mathrm{g} / \mathrm{mL}$ de sulfato de estreptomicina, $0,25 \mu \mathrm{g} / \mathrm{mL}$ de anfotericina B e 10\% de Soro Fetal Bovino (SFB, Gibco-BRL). Os cultivos foram estabelecidos, mantidos e expandidos em incubadora a $38,5^{\circ} \mathrm{C}$, com atmosfera controlada de $5 \%$ de $\mathrm{CO}_{2}$ em umidade saturada.

Partidas de células foram congeladas até no máximo a terceira passagem para uso nas rotinas de clonagem por HMC. Brevemente, quando os cultivos atingiram confluência maior que $90 \%$, as células foram suspensas em meio de cultivo com 10\% de dimetil sulfóxido (DMSO), envasadas assepticamente em palhetas estéreis de $0,25 \mathrm{~mL}$ em volume aproximado 
de $150 \mu \mathrm{L}$, para uma concentração de $1 \times 10^{3}$ células $/ \mu \mathrm{L}$. As palhetas foram mantidas entre 2 a $4^{\circ} \mathrm{C}$ por 15 min e então expostas ao vapor de nitrogênio líquido $\left(\mathrm{N}_{2} \mathrm{~L}\right)$ a uma temperatura entre -80 a $-110^{\circ} \mathrm{C}$ por 5 min, sendo imersas em $\mathrm{N}_{2} \mathrm{~L}$ e estocadas em botijão criogênico para uso posterior. A descongelação foi realizada $72 \mathrm{~h}$ antes da utilização na rotina de clonagem por $\mathrm{HMC}$, por imersão em água a $36^{\circ} \mathrm{C}$ por $30 \mathrm{~s}$, seguido do cultivo em placa de cultivo celular de 4 poços $\left(\right.$ Nunclon ${ }^{\circledR} 144444$, Nunc, Roskilde, Dinamarca), visando obter uma confluência elevada (>95\%) 24 h antes de sua utilização (GERGER et al., 2010).

\subsubsection{Produção In Vivo de Embriões}

Cinco fêmeas multíparas bovinas da raça Nelore (registradas na ABCZ), selecionadas de um único rebanho comercial, foram utilizadas para a obtenção de embriões in vivo (Controle), com posterior transferência dos embriões a fresco. Cinco fêmeas foram superovuladas (SOV) e coletadas, no mesmo dia, no primeiro protocolo de superovulação e inseminação a tempo fixo (IATF); destas, duas foram submetidas ao mesmo procedimento 90 dias após o término do primeiro. Após os sete procedimentos de superovulação e inseminação artificial (IA), utilizando sêmen de touro Nelore (registrado na ABCZ), os embriões foram coletados pelo método não-cirúrgico por lavagem uterina, no dia 7 de desenvolvimento (IA = dia 0), seguindo os procedimentos preconizados por Stringfellow e Seidel (1998) e sucintamente descritos abaixo.

Previamente à realização da coleta de embriões em cada fêmea, realizou-se o esvaziamento retal, a assepsia do períneo, seguidos da anestesia epidural entre a última vértebra sacral e a primeira coccígea com lidocaína a 2\% (4-5 mL). Em seguida, inseriu-se um cateter tipo Foley ( $\left.n^{\circ} 20\right)$ no corpo do útero por via cervical, utilizando-se um circuito fechado para a realização da lavagem uterina com $1 \mathrm{~L}$ de solução tampão fosfato salino (DPBS Nutricell, Nutrientes Celulares, Campinas, SP) recolhido em filtro coletor de embriões. A lavagem do lúmen uterino foi auxiliada por massagem via retal. Ao término da infusão de solução PBS, o balão foi desinflado e o cateter removido.

A procura dos embriões foi realizada em placa de Petri de $100 \mathrm{~mm}$, em DPBS, sob lupa estereomicroscópica com magnitude de até $60 \mathrm{X}$. Os embriões viáveis foram transferidos para uma placa de Petri de $35 \mathrm{~mm}$ contendo meio comercial de manipulação de embriões (TQC Holding Plus ${ }^{\circledR}-$ Nutricell, Nutrientes Celulares, Campinas, SP), e classificados 
morfologicamente segundo Stringfellow e Seidel (1998), sendo em seguida envasados em palhetas de $0,25 \mathrm{~mL}$ para serem transferidos a fresco.

O protocolo de SOV e de IATF das doadoras encontra-se descrito abaixo.

(Dia 0) Inserção do dispositivo vaginal de liberação controlada de $\mathrm{P}_{4}{ }^{1}+2 \mathrm{mg}$ de $\mathrm{BE}^{2}$

(Dia 4) Início da superovulação: 20\% da dose total de $\mathrm{FSH}^{3}$ às 7:00 h e 20\% às 19:00 h

(Dia 5) $15 \%$ da dose total de FSH às 7:00 h e 15\% às 19:00 h

(Dia 6) $10 \%$ da dose total de FSH às 7:00 $\mathrm{h}+\mathrm{PGF}_{2 \alpha}{ }^{4}(250 \mu \mathrm{g})$ e $10 \%$ às 19:00 $\mathrm{h}$

(Dia 7) $5 \%$ da dose total de FSH às 7:00 $\mathrm{h}+$ retirada do dispositivo e $5 \%$ às 19:00 $\mathrm{h}$

(Dia 8$) \mathrm{LH}^{5}$ às 7:00 h e IA às 19:00 h

(Dia 9) IA às 7:00 h

(Dia 16) Coleta dos embriões

${ }^{1} \mathrm{P}_{4}=$ Progesterona $\left(\mathrm{CIDR}^{\circledR}\right.$ - Pfizer Animal Health, São Paulo, SP, Brasil)

${ }^{2} \mathrm{BE}=$ Benzoato de Estradiol (Estrogin ${ }^{\circledR}$ - Farmavet, Brasil), por via IM

${ }^{3} \mathrm{FSH}=$ Hormônio Folículo Estimulante (Folltropin ${ }^{\circledR}$ - V - Bioniche Animal Health Inc., Canadá), Dose Total de $133 \mathrm{mg}$, por via IM

${ }^{4} \mathrm{PGF}_{2 \alpha}=$ Dinoprost, análogo da Prostaglandina $\left(\right.$ Lutalyse $^{\circledR}$ - Pharmacia-Upjohn Co., MI, EUA), por via IM

${ }^{5}$ LH - Hormônio Luteinizante (Lutropin ${ }^{\circledR}$ - V - Bioniche Animal Health Inc, Canadá), por via IM

\subsubsection{Produção In Vitro de Embriões por Fecundação In Vitro}

Para a produção in vitro (PIV) dos embriões por fecundação in vitro (FIV) realizaramse cinco repetições de procedimentos de punção folicular por via vaginal guiada por ultrasonografia, ou ovum pick-up (OPU), a partir de 10 fêmeas bovinas multíparas da raça Nelore (registradas na ABCZ), em um total de 28 aspirações. Estes animais faziam parte do mesmo rebanho das fêmeas utilizadas para a produção in vivo dos embriões, com três fêmeas sendo utilizadas tanto na produção in vivo quanto na in vitro.

Punção Folicular in vivo - A OPU foi realizada utilizando-se a metodologia descrita primeiramente por Pieterse et al. (1988) e adaptada por Seneda et al. (2003), conforme descrito abaixo.

Previamente à realização do procedimento de OPU em cada fêmea, realizou-se o esvaziamento retal, a assepsia do períneo, seguida da anestesia epidural com lidocaína a $2 \%$ (4-5 mL), entre a última vértebra sacral e a primeira coccígea. A aspiração folicular ovariana foi realizada com auxílio de ultrasom (Aloka - SSD 500V), utilizando transdutor linear (freqüência de 5,0 MHz), acoplado a uma guia transvaginal para bovinos (Watanabe 
Tecnologia Aplicada Ltda., Brasil) envolvida por uma camisa sanitária, sendo então introduzida por via vaginal até o fórnix, com cada ovário posicionado junto à parede da vagina por palpação retal. Agulhas curtas descartáveis de 70 x 10 mm (Watanabe Tecnologia Aplicada Ltda. - Brasil) foram utilizadas para a punção dos folículos (diâmetro mínimo de 3 $\mathrm{mm}$ ) por pressão de vácuo correspondente a $10-15 \mathrm{~mL} / \mathrm{min}$ de fluido, exercida por uma bomba de infusão contínua hospitalar adaptada para esta finalidade (Nutrimat II $^{\circledR}$ B/BRAUN). A agulha e o tubo cônico de centrífuga de $50 \mathrm{~mL}$, utilizado para a captação do conteúdo aspirado, foram conectados por intermédio de uma sonda de teflon conduzida pela guia de punção.

Para servir de meio de aspiração e evitar a interrupção do fluxo do sistema por coágulos sanguíneos, heparina sódica (Liquemine ${ }^{\circledR}$, Roche) na razão de $25 \mathrm{UI} / \mathrm{mL}$ de solução DPBS foi utilizada para lavar o sistema em intervalos curtos de tempo. Ao término do processo, o tubo de $50 \mathrm{~mL}$, contendo aproximadamente $30 \mathrm{~mL}$ de meio de coleta e conteúdo folicular, foi encaminhado ao laboratório adaptado próximo ao centro de manejo de animais.

O tubo foi vertido em filtro coletor (Watanabe Tecnologia Aplicada Ltda. - Brasil) e lavado com a solução de aspiração, a $37^{\circ} \mathrm{C}$. Após a lavagem, o conteúdo residual (complexos cumulus-oócitos, oócitos, células, debris, muco e coágulos sanguíneos) foi depositado em placa de Petri de 100 × $20 \mathrm{~mm}$ para a procura dos complexos cumulus-oócitos (CCOs) em lupa estereomicroscópica com magnitude de até 60X. Os CCOs encontrados foram avaliados e transferidos para tubos de criopreservação (Corning Incorporated, NY, EUA) contendo meio de transporte M199H composto por TCM-199 (M2520), suplementado com 2,4 mM de $\mathrm{NaHCO}_{3}, 2,0 \mathrm{mM}$ de piruvato de sódio, e acrescido de $10 \%$ de Soro de Égua em Estro inativado (SEE), 0,5 $\mu \mathrm{g} / \mathrm{mL}$ de FSH (Folltropin ${ }^{\circledR}$ - V, Bioniche Animal Health Inc., Canadá) e $5 \mu \mathrm{g} / \mathrm{mL}$ de LH (Lutropin ${ }^{\circledR}-\mathrm{V}$, Bioniche Animal Health Inc., Canadá). Os CCOs foram transportados ao laboratório a $37^{\circ} \mathrm{C}$. Não se utilizou qualquer tipo de estímulo hormonal prévio ou sincronização dos ciclos estrais nos animais doadores para a realização das aspirações.

Produção in vitro dos embriões - Os procedimentos de maturação, fecundação e cultivo in vitro foram realizados em placas de cultivo celular de 4-poços, de acordo com Ribeiro et al. (2009).

Maturação in vitro (MIV) - Os CCOs aspirados in vivo das foram submetidos à MIV em placas contendo meio M199 composto por TCM-199 (M2520), suplementado com 26,2 
$\mathrm{mM}$ de $\mathrm{NaHCO}_{3}, 0,2 \mathrm{mM}$ de piruvato de sódio, e acrescido de $0,5 \mu \mathrm{g} / \mathrm{mL}$ de FSH, $5 \mu \mathrm{g} / \mathrm{mL}$ de $\mathrm{LH}$ e $10 \%$ de $\mathrm{SEE}$ a $38,5^{\circ} \mathrm{C}, 5 \% \mathrm{CO}_{2}$ em ar e umidade saturada.

Fecundação in vitro (FIV) - Imediatamente após o descongelamento do sêmen, os espermatozóides (sptz) viáveis foram selecionados pelo método de swim up, mediante incubação por $1 \mathrm{~h}$ a $38,5^{\circ} \mathrm{C}$ em meio Talp-Sperm (PARRISH et al., 1988). A fecundação foi realizada com a concentração de 1 x $10^{6} \mathrm{sptz} / \mathrm{mL}$ em meio Talp-Fert (PARRISH et al., 1988) adicionado de $5 \mathrm{UI} / \mathrm{mL}$ de heparina, $0,72 \mu \mathrm{g} / \mathrm{mL}$ de penicilamina, $0,26 \mu \mathrm{g} / \mathrm{mL}$ de hipotaurina e $0,04 \mu \mathrm{g} / \mathrm{mL}$ de epinefrina. A co-incubação dos CCOs e sptz ocorreu por um período de 18 a 22 h. O sêmen utilizado foi proveniente do mesmo touro da raça Nelore utilizado na produção in vivo de embriões.

Cultivo in vitro (CIV) - Ao final do período de fecundação, foi procedida a remoção das células do cumulus dos presumíveis zigotos por pipetagem contínua e a transferência das estruturas para o meio SOFaaci (HOLM et al., 1999) suplementado com 0,34 mM de citrato tri-sódico, 2,77 mM de mio-inositol, $30 \mu \mathrm{L} / \mathrm{mL}$ de aminoácidos essenciais (BME - B 6766) e $10 \mu \mathrm{L} / \mathrm{mL}$ de aminoácidos não essenciais (MEM - M 7145), acrescido de 5\% de SEE e mantido sob óleo mineral. O CIV foi realizado seguindo o sistema foil bag desenvolvido por Vajta et al. (1997), com atmosfera de $5 \% \mathrm{CO}_{2}, 5 \% \mathrm{O}_{2}, 90 \% \mathrm{~N}_{2}$, por mais $144 \mathrm{~h}$ (FIV $=$ hora $0)$. Avaliou-se a taxa de clivagem com $48 \mathrm{~h}$ de CIV.

\subsubsection{Produção In Vitro de Embriões por Transferência Nuclear de Célula Somática e por Partenogênese}

A produção in vitro (PIV) dos embriões por transferência nuclear de célula somática (TNCS) foi realizada utilizando a metodologia do Handmade Cloning (HMC), desenvolvida por Vajta et al. (2003) e adaptada às condições de nosso laboratório (RIBEIRO et al., 2009; GERGER et al., 2010), conforme abaixo.

Maturação in vitro (MIV) - Os CCOs aspirados de ovários bovinos coletados de três frigoríficos regionais foram morfologicamente selecionados em Graus 1, 2 e 3 segundo a classificação de Gonçalves, Figueiredo e Freitas (2008), e submetidos à MIV por 17 h, em placas contendo meio M199 acrescido de $0,5 \mu \mathrm{g} / \mathrm{mL}$ de FSH, $5 \mu \mathrm{g} / \mathrm{mL}$ de $\mathrm{LH}$ e $10 \%$ de SEE, a $38,5^{\circ} \mathrm{C}, 5 \% \mathrm{CO}_{2}$ em ar e umidade saturada. 
Transferência nuclear de célula somática - As células do cumulus oophorus e da corona radiata foram removidas dos CCOs por pipetagem contínua em M199H acrescido de $10 \%$ de SFB. Em seguida, os oócitos maturos foram selecionados pela presença do $1^{\circ}$ corpúsculo polar, sob lupa estereomicroscópica. Destes, removeu-se a zona pelúcida (ZP) pela breve exposição a uma solução de protease (P-8811) a 0,5\% em M199H + 0,01\% de álcool polivinílico (PVA). Em seguida, os oócitos sem ZP foram incubados por $10 \mathrm{~min}$ em $5 \mu \mathrm{g} / \mathrm{mL}$ de citocalasina $\mathrm{B}(\mathrm{CCB}, \mathrm{C}-6762)$ em M199H + 10\% de SFB, e submetidos à bisecção manual, em grupos de 2 a 3 oócitos por microgotas de $5 \mu \mathrm{L}$ do mesmo meio com $\mathrm{CCB}$, sob óleo mineral, utilizando-se uma lâmina de bisecção (Ultra-sharp Splitting Blade, Bioniche Inc., EUA), sob lupa estereomicroscópica. Após a bisecção, e seguindo-se a incubação em 10 $\mu \mathrm{g} / \mathrm{mL}$ de bisbenzimida (Hoechst 33342, B-2261) em M199H + SFB por 10 min, os hemioócitos contendo aproximadamente $50 \%$ do volume citoplasmático original foram selecionados em um microscópio invertido de epifluorescência (XDY-1, China) com filtro UV em enucleados e nucleados, conforme a presença da placa metafásica. Os hemi-oócitos enucleados (hemi-citoplastos) foram lavados em M199H + SFB para uso na reconstrução embrionária.

Os embriões foram reconstruídos com reconstituição de aproximadamente $100 \%$ do volume citoplasmático inicial, com dois hemi-citoplastos sendo dispostos linearmente com a célula somática doadora de núcleo em uma das extremidades. Procurou-se utilizar apenas as menores células, arredondadas e com a membrana celular intacta, visando o aumento na proporção de células na fase G0/G1 do ciclo celular (BOQUEST; DAY; PRATHER, 1999). A agregação das estruturas ocorreu mediante a exposição a $500 \mu \mathrm{g} / \mathrm{mL}$ de fitohemoaglutinina (PHA, L-8754) em M199H + PVA. As estruturas reconstruídas foram lavadas em M199H + $\mathrm{SFB}$, equilibradas em meio de eletrofusão (EF) contendo 0,3 $\mathrm{M}$ de manitol, 0,05 $\mathrm{mM}$ de $\mathrm{CaCl}_{2} \cdot 2 \mathrm{H}_{2} \mathrm{O}, 0,1 \mathrm{mM}$ de $\mathrm{MgSO}_{4} \cdot 7 \mathrm{H}_{2} \mathrm{O}, 0,5 \mathrm{mM}$ de Hepes e $0,01 \%$ de PVA, para então serem distribuídas em uma câmara de fusão de 3,2 mm de espaço entre eletrodos (BTX 453, BTX Instruments, Genetronics, CA, EUA) contendo $650 \mu \mathrm{l}$ de meio EF, acoplada a um aparelho de eletrofusão (BTX Electro Cell Manipulator 200, Biotechnologies \& Experimental Research Inc., San Diego, CA, EUA). Os complexos reconstruídos foram submetidos a um pré-pulso de corrente alternada (AC) de $15 \mathrm{~V}$ por $5 \mathrm{~s}$ para a indução do alinhamento, seguido de dois pulsos elétricos de corrente contínua (DC) de $1,25 \mathrm{kV} / \mathrm{cm}$ por $20 \mu \mathrm{s}$ para a fusão das membranas celulares.

As estruturas submetidas à fusão foram cultivadas individualmente, em microgotas de $5 \mu \mathrm{L}$ sob óleo, em incubadora a $38,5^{\circ} \mathrm{C}, 5 \%$ de $\mathrm{CO}_{2}$ e umidade saturada por 60 min em M199 
+ SFB para a avaliação da taxa de fusão. Os embriões fusionados, e grupos de oócitos com ZP intacta (grupo controle - partenotos), foram quimicamente ativados 2,3 $\pm 0,6 \mathrm{~h}$ após a fusão (25,0 $\pm 1,0 \mathrm{~h}$ após o começo da MIV) em $5 \mu \mathrm{M}$ de ionomicina (I-0634) em M199H por 5 min, seguido da incubação individualizada em $5 \mu \mathrm{L}$ de M199 + SFB contendo 2 mM de 6dimetilaminopurina (6-DMAP, D-2629), sob óleo mineral, durante $4 \mathrm{~h}$.

Cultivo in vitro (CIV) - Embriões clonados e partenotos ativados foram submetidos ao CIV pelo sistema Well-of-the-Well (WOW), ou de micro-poços, de acordo com Vajta et al. (2000), e modificado por Feltrin et al. (2006). Os embriões foram dispostos individualmente ou em dupla, resultando em um volume citoplasmático final aproximado de $100 \%$ e $200 \%$ em cada micro-poço. Os micro-poços foram confeccionados manualmente dentro de poços de placas 4-poços contendo $400 \mu \mathrm{L}$ de meio SOFaaci (HOLM et al., 1999) suplementado com 0,34 $\mathrm{mM}$ de citrato tri-sódico, 2,77 $\mathrm{mM}$ de mio-inositol, $30 \mu \mathrm{L} / \mathrm{mL}$ de aminoácidos essenciais (BME - B 6766) e $10 \mu \mathrm{L} / \mathrm{mL}$ de aminoácidos não essenciais (MEM - M 7145), acrescido de $5 \%$ de SEE, $5 \mu \mathrm{g} / \mathrm{mL}$ de insulina, $5 \mu \mathrm{g} / \mathrm{mL}$ de transferrina e $5 \mathrm{ng} / \mathrm{mL}$ de selenito de sódio (ITS-X, I-1884), sob óleo mineral. As placas foram incubadas em sistema foil bag (VAJTA et al., 1997), com atmosfera de $5 \% \mathrm{CO}_{2}, 5 \% \mathrm{O}_{2}$ e $90 \% \mathrm{~N}_{2}$, a $39^{\circ} \mathrm{C}$ por $168 \mathrm{~h}$ (ativação = hora 0) até o estádio de blastocisto. Com $48 \mathrm{~h}$ de cultivo realizou-se a avaliação da clivagem.

\subsubsection{Transferência de Embriões}

As transferências dos embriões dos três grupos (Controle, FIV e TNCS) ocorreram para receptoras previamente sincronizadas, no dia 7 do ciclo estral, utilizando-se o protocolo descrito por Baruselli et al. (2010) de transferência de embriões em tempo fixo (figura 6.1), por médicos veterinários experientes, e seguindo os procedimentos preconizados por Stringfellow e Seidel (1998).

O transporte dos embriões dos grupos FIV e TNCS ocorreu em palhetas de 0,25 mL, contendo meio de transporte $\mathrm{M} 199 \mathrm{H}$ acrescido de $10 \%$ ou $20 \%$ de SFB, para os embriões do grupo FIV e TNCS, respectivamente, a uma temperatura média de $37^{\circ} \mathrm{C}$. Os embriões in vivo (Controle) produzidos por SOV/IATF foram transferidos a fresco na própria fazenda, sem a necessidade de transporte conforme descrito para os outros dois grupos. Os embriões dos grupos Controle e FIV foram transferidos individualmente, e os do grupo TNCS individualmente ou em dupla para cada receptora. 


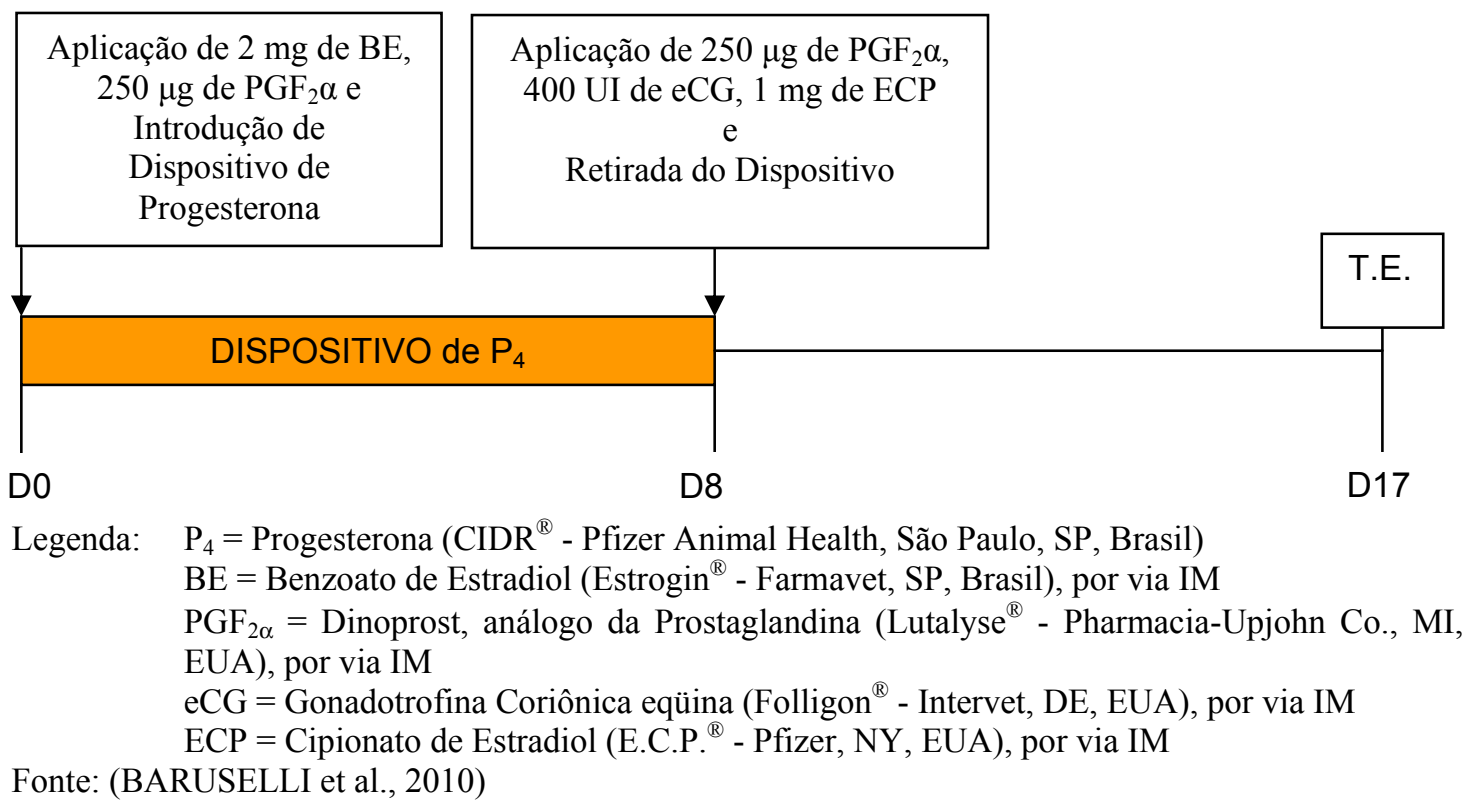

Figura 6.1 - Protocolo utilizado para sincronização do estro das fêmeas receptoras de embriões

\subsubsection{Exames Ultrasonográficos}

Os diagnósticos de prenhez e do sexo fetal foram conduzidos por ultrasonografia (Aloka $^{\text {TM }}$ SSD-500V ou 100 Falco $^{\circledR}$ - Pie Medical) por via retal nos dias 30 e 58 de gestação, respectivamente. Exames ultrasonográficos foram conduzidos até os 93 dias de prenhez em todos os animais. A partir de então, as prenhezes foram monitoradas por palpação retal com intervalos de duas semanas até o Dia 225 de desenvolvimento, com exames esporádicos por ultrasonografia para avaliação de possíveis anormalidades ou da confirmação da viabilidade fetal.

Imagens de prenhezes dos três grupos (Controle, FIV e TNCS) foram gravadas em fitas de vídeo VHS de animais aos 51 dias de gestação para a mensuração de parâmetros físicos de cada concepto, em um comparativo da morfometria entre os grupos. Além da freqüência cardíaca, mensuraram-se os comprimentos do feto (processo occipital até as primeiras vértebras coccígeas), da cabeça do feto (processo occipital até o plano nasal), da vesícula amniótica e do comprimento e altura dos placentônios próximos ao feto, conforme descrito previamente (BERTOLINI et al., 2002a). Os locais aproximados destas mensurações nos sonogramas estão ilustrados na figura 6.2. 
Após a gravação das imagens, as mesmas foram digitalizadas, gravadas em DVD e analisadas quadro a quadro (frame-by-frame) utilizando o programa Quick Time Player (versão 7.6.2, Quick Time ${ }^{\circledR}$, Apple Inc., CA, EUA). Os quadros (frames) foram gravados em formato JPEG, e as imagens mensuradas individualmente no programa de análise de imagens ImageJ (programa de domínio público, obtido do sítio da internet: http://rsbweb.nih.gov/ij/). Os dados foram compilados para planilhas do Excell, para a realização da análise estatística.
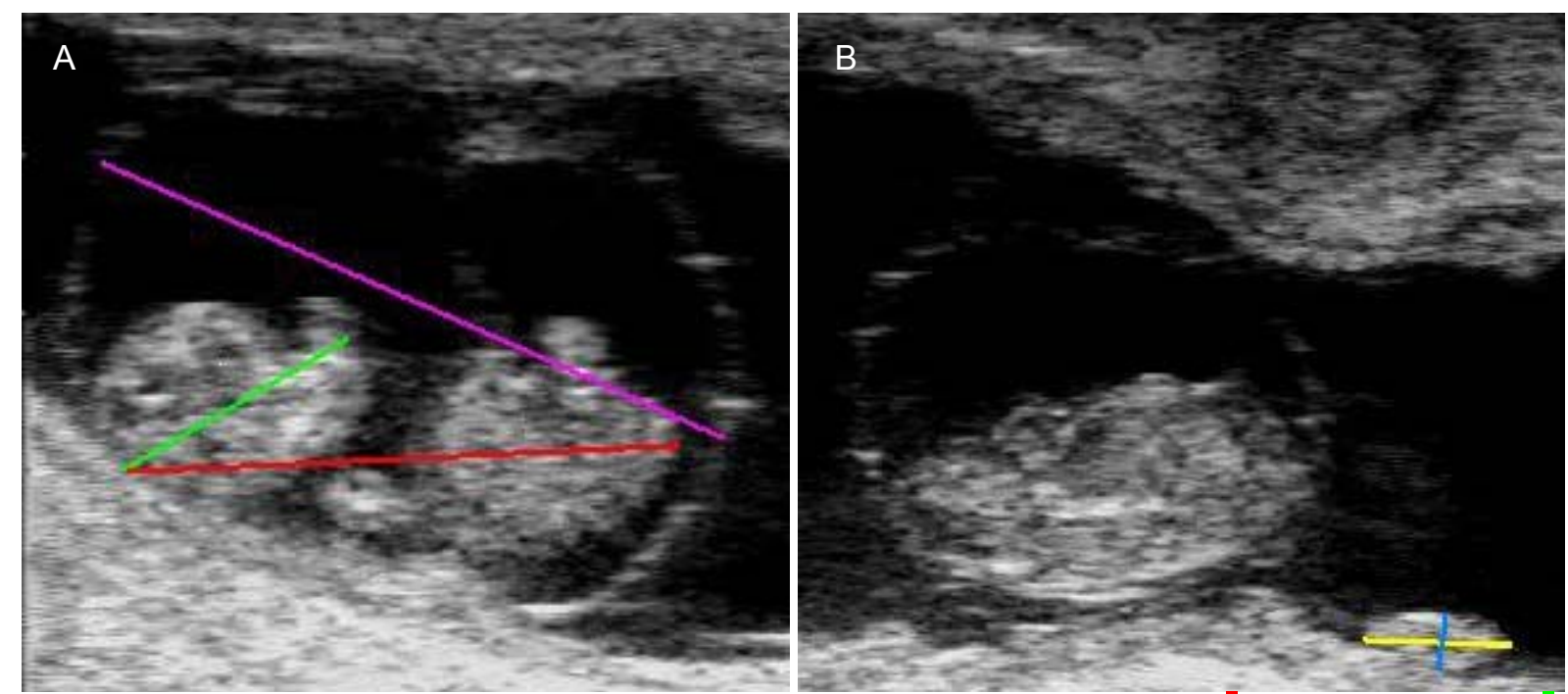

Legenda: As linhas coloridas exemplificam os locais de cada mensuração: (†) comprimento fetal, (-) comprimento da cabeça, (†) vesícula amniótica, (-) comprimento do placentônio, (-) altura do placentônio

Figura 6.2 - Sonogramas de um dos animais do grupo TNCS aos 51 dias de gestação. (A) Vista sagital do concepto; (B) Placentônio próximo ao feto

\subsubsection{Coleta de Sangue, Fluidos e Tecidos Maternos e Fetais aos 225 Dias de Gestação}

Quatorze fêmeas bovinas sem raça definida (Bos taurus vs. Bos indicus), prenhes de embriões da raça Nelore produzidos in vivo (Controle $=4)$, PIV/FIV (FIV $=4$ ) e PIV/TNCS (TNCS $=6$ ), foram abatidas aos $225 \pm 2$ dias de gestação. O procedimento de coleta das amostras, descrito por Bertolini et al. (2004), foi adaptado às nossas condições e encontra-se descrito a seguir.

Após um jejum alimentar de $12 \mathrm{~h}$, as fêmeas prenhes foram encaminhadas para frigoríficos com Serviço de Inspeção Municipal nos municípios de Lages e Itajaí, no Estado de Santa Catarina. As fêmeas foram conduzidas ao brete de atordoamento, e dessensibilizadas com o emprego de pistola pneumática, seguindo-se da sangria com a coleta de sangue 
materno, que foi imediatamente processado e amostrado. $\mathrm{O}$ útero prenhe foi removido da cavidade abdominal intacto (sem perda de fluidos) pela secção do ligamento largo e porção cranial da vagina, sendo conduzido para uma mesa próxima à linha de abate, onde foi pesado e dissecado ao longo da curvatura maior. Os fluidos amniótico e alantóico foram cuidadosamente coletados, separadamente, mensurados, processados e amostrados. O feto foi removido do lúmen uterino com o cordão umbilical ainda intacto. Amostras sanguíneas foram coletadas da artéria e veia umbilical por vasopunção, processadas e amostradas. Todos os fetos encontravam-se vivos e bastante ativos, com o coração ainda em atividade enquanto as amostras eram coletadas. Após a coleta de sangue fetal, realizou-se a excisão do cordão umbilical. O trato uterino vazio, sem o feto e fluidos, apenas com a placenta e membranas fetais, foi finalmente pesado.

Mensurações morfológicas foram realizadas nos fetos, tais como peso, comprimento da cabeça (plano nasal ao processo occipital), do corpo (processo occipital à última vértebra sacral), dos membros torácicos e pélvicos, do úmero, da diáfise umeral, do fêmur, da diáfise femoral, da circunferência torácica e do diâmetro da órbita ocular. Os músculos esqueléticos supraespinhoso, grande dorsal, semitendinoso e bíceps femoral foram cuidadosamente dissecados, medidos, pesados, e amostras foram fixadas em glutaraldeído a 2,5\% e outras congeladas em $\mathrm{N}_{2} \mathrm{~L}$. Da mesma forma, os órgãos viscerais fetais (coração, pulmão, cérebro, cerebelo, rins, fígado, baço, pâncreas, timo, trato gastrointestinal, traquéia e gônadas) e glândulas endócrinas (tireóide, adrenais e hipófise) foram dissecados e pesados, com amostras sendo fixadas e congeladas. O tecido adiposo marrom, a medula óssea e alguns linfonodos foram apenas dissecados, com amostras sendo fixadas e congeladas, conforme acima.

Todos os placentônios foram excisados do útero pelo pedúnculo caruncular, classificados individualmente quanto à morfologia em tipos $\mathrm{A}, \mathrm{B}, \mathrm{C}$ ou $\mathrm{D}$ conforme ilustrado na figura 6.3 segundo Bertolini, Wallace e Anderson (2006), sendo em seguida pesados e mensurados linearmente (comprimento e largura). Para o cálculo da área de superfície dos placentônios, utilizou-se a equação da área de superfície da elipse: [(comprimento/2) * (largura/2) $* \pi]$. 
(A)

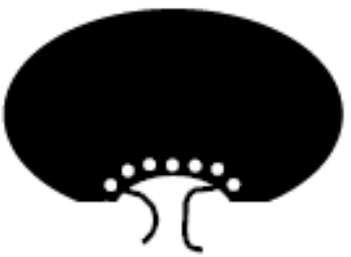

(C)

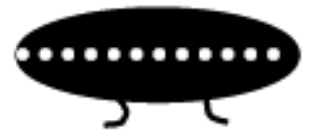

(B)

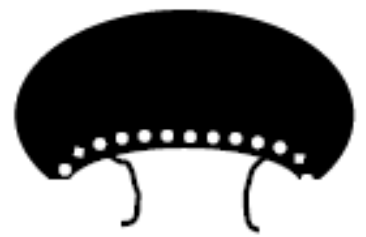

(D)

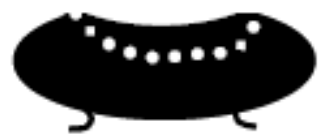

Legenda: (A) placentônio com formato de cogumelo engolfado; (B) placentônio com formato de cogumelo semi-engolfado; (C) placentônio com formato achatado sem engolfamento; (D) placentônio com formato semi-convexo. O pontilhado branco representa a interface entre o tecido fetal (superior) e o materno (próximo ao pedúnculo).

Fonte: (BERTOLINI; WALLACE; ANDERSON, 2006)

Figura 6.3 - Esquema utilizado para classificação dos placentônios segundo a morfologia individual

Amostras do eixo longitudinal central de cada um dos tipos de placentônio foram fixadas em glutaraldeído a $2,5 \%$ e outras congeladas em $\mathrm{N}_{2} \mathrm{~L}$. O útero (sem conteúdo e placentônios) e as membranas fetais foram finalmente pesados individualmente.

Amostras coletadas do fígado materno foram parte fixadas em glutaraldeído a 2,5\% e parte congeladas em $\mathrm{N}_{2} \mathrm{~L}$.

6.1.7.1 Processamento do Sangue Materno e Fetal e dos Fluidos Fetais após o Abate

Para o processamento sanguíneo das amostras fetais e materna, uma parcela do sangue foi transferida para tubos de $5 \mathrm{~mL}$ e congelada diretamente em $\mathrm{N}_{2} \mathrm{~L}$, sendo outra centrifugada por 15 min a 6000 g para a obtenção de plasma, o qual foi alíquotado e congelado em $\mathrm{N}_{2} \mathrm{~L}$ para posterior análise.

Os fluidos amniótico e alantóico foram coletados e mensurados separadamente em proveta de $1000 \mathrm{~mL}$. Uma amostra de $20 \mathrm{~mL}$ de cada fluido foi retirada e centrifugada por 15 min a 6000 g para obtenção de um líquido sem debris celulares. O sobrenadante de cada fluido foi transferido para tubos de $5 \mathrm{~mL}$ e congelado em $\mathrm{N}_{2} \mathrm{~L}$ para posterior análise. 
A quantificação dos substratos (glicose e frutose) foi conduzida por espectrofotometria, de acordo com Bertolini et al. (2004). As amostras foram analisadas em duplicata, utilizando o plasma sanguíneo de cada amostra materna e fetal e dos fluidos amniótico e alantóico de todos os animais.

A glicose foi determinada por colorimetria com um kit de ensaio enzimático (QuantiChrom $^{\mathrm{TM}}$ Glucose Assay Kit) da BioAssay Systems (BioAssay Systems, Hayward, CA, EUA), seguindo as recomendações do fabricante, com pequenas modificações. Brevemente, $6 \mu \mathrm{L}$ de cada amostra ou solução-padrão (nas concentrações de 0, 50, 100, 200 e $300 \mathrm{mg} / \mathrm{dL}$ ) foram dispostos em tubos de microcentrífuga de 1,5 mL (Eppendorf, Hamburgo, Alemanha), seguido da adição de $300 \mu \mathrm{L}$ da solução de ensaio (fornecida no kit). Os tubos foram fechados e levemente agitados, sendo colocados em banho-maria a $100^{\circ} \mathrm{C}$ por exatos 8 min. Na seqüência, os tubos foram rapidamente resfriados em água com gelo por no mínimo 4 min, encerrando a reação química. As amostras e soluções-padrão foram alocadas em duplicata em poços de placas de 96-poços, com a leitura realizada em leitor de ELISA (Biotrak II Reader ${ }^{\circledR}$, Amersham Biosciences, NJ, EUA) ajustada para um comprimento de onda de $620 \mathrm{~nm}$.

Para a mensuração da frutose, utilizou-se a metodologia descrita por Taylor (1995). De forma sucinta, $10 \mu \mathrm{L}$ de cada amostra ou solução-padrão (nas concentrações de 0, 12,5, 25, 50, 100 e $200 \mathrm{mg} / \mathrm{dL}$ ) foram dispostos em tubos de microcentrífuga de 2,0 mL (Eppendorf, Hamburgo, Alemanha), com a adição de $60 \mu \mathrm{L}$ de uma solução de $10 \mathrm{mM}$ de hidrocloreto de triptamina [3-(2-Aminoetil) indol $\mathrm{HC1}$ ] em $\mathrm{HCl}$ a $0,1 \mathrm{M}$, seguido da adição de $1,8 \mathrm{~mL}$ de $\mathrm{HCl}$ a $12 \mathrm{~N}$. Os tubos foram fechados e colocados em banho-maria a $60^{\circ} \mathrm{C}$ por exatos $15 \mathrm{~min}$, sendo rapidamente resfriados em água com gelo por no mínimo $5 \mathrm{~min}$. As amostras e soluções-padrão foram dispostas (em duplicatas) em micro-cuvetas de plástico (PlastiBrand $^{\circledR}$, Alemanha) com $750 \mu \mathrm{L}$ de solução cada. A leitura foi realizada em espectrofotômetro (Ultrospec $1100 \mathrm{PRO}^{\circledR}$, Amersham Biosciences, NJ, EUA) ajustada para um comprimento de onda de $518 \mathrm{~nm}$. Pela elevada concentração de frutose, as amostras fetais (artéria e veia) e de fluido amniótico, bem como de fluido alantóide, foram diluídas em água, previamente à análise, em uma proporção de 1:2 e 1:4, respectivamente.

As amostras que apresentaram uma diferença maior do que $6 \%$ no coeficiente de variação intra-ensaio, tanto para a glicose quanto para a frutose, foram re-analisadas. As concentrações de glicose e frutose em todas as amostras foram calculadas a partir da média dos ensaios realizados, e baseando-se na fórmula da regressão linear obtida com os valores das soluções-padrão. 
A osmolalidade do plasma sanguíneo e dos fluidos amniótico e alantóico foram mensuradas em duplicata em osmômetro (Osmomat 030 ${ }^{\circledR}$, Gonotec Gmbh, Berlim, Alemanha), com a utilização de $50 \mu \mathrm{L}$ de cada amostra dispostos em tubos de microcentrífuga de $0,5 \mathrm{~mL}$.

\subsection{ANÁLISE ESTATÍSTICA}

Os dados qualitativos de taxa de prenhez e perdas gestacionais acumuladas foram comparadas pelo teste de $\chi^{2}$ ou de Fisher. Para a análise dos dados quantitativos morfométricos, morfológicos e bioquímicos, utilizaram-se as análises de variância (ANOVA) e de co-variância (ANCOVA), com o peso fetal como co-variável para os conjuntos de variáveis pertinentes ao feto, com comparações pareadas entre os grupos realizadas pelo teste de Tukey, utilizando o GLM do Minitab Statistical Software (Minitab, State College, PA, EUA). Os dados referentes à distribuição do tipo de placentônio foram analisados pelo teste de Kruskal-Wallis. Os dados referentes à freqüência do comprimento dos placentônios foram analisados pelo teste de Mann-Whitney. Também foi utilizado o teste de correlação de Pearson para a análise da relação entre todas as características mensuradas. Todos os testes utilizaram nível de significância de 5\%, com valores de "P" entre $0,10<p<0,05$, considerados como tendência estatística.

\subsection{RESULTADOS}

Os resultados dos experimentos foram separados de forma cronológica, de acordo com a fase experimental em que foram obtidos, e apresentados desta forma para melhor interpretação e apresentação dos dados. 


\subsubsection{Produção de Embriões, Diagnóstico de Gestação e do Gênero Fetal}

\section{Embriões produzidos in vivo (Controle) por SOV e IATF.}

Dos sete protocolos de produção e coleta in vivo dos embriões, a partir de cinco fêmeas, um total de 28 estruturas foram recuperadas $(4,0 \pm 3,8)$, das quais $16(2,3 \pm 3,1)$ foram avaliadas como embriões viáveis (57,1\%). Transferiram-se 12 embriões, individualmente e a fresco, para fêmeas receptoras, com sete prenhezes $(58,3 \%)$ sendo diagnosticadas por ultrasonografia aos 30 dias de gestação. Destas, duas abortaram com 37 e 180 dias de gestação, e uma foi diagnosticada com gêmeos supostamente idênticos, provavelmente após bipartição natural do embrião após a TE, sendo removida do experimento. As quatro gestações remanescentes, diagnosticadas aos 58 dias com dois machos e duas fêmeas, foram abatidas aos 225 dias de gestação, quando os gêneros fetais foram re-confirmados.

\section{Embriões produzidos in vitro por FIV.}

No grupo FIV, foram recuperados 486 oócitos viáveis (17,4 oócitos/doadora) de 28 procedimentos de OPU realizados em cinco repetições $(97,2 \pm 12,0$ oócitos/repetição), gerando, após a PIV de embriões, um total de 29 embriões $(6,0 \%)$ no dia 7 de desenvolvimento. Destes embriões, apenas 22 foram transferidos individualmente e a fresco, para fêmeas receptoras, obtendo-se cinco prenhezes $(22,7 \%)$ aos 30 dias de gestação. Uma destas fêmeas abortou aos 37 dias de gestação. As quatro prenhezes restantes, diagnosticadas aos 58 dias com dois machos e duas fêmeas, foram abatidas aos 225 dias de gestação, quando os gêneros fetais foram re-confirmados.

\section{Embriões produzidos in vitro por TNCS.}

Foi realizado um total de 20 rotinas de PIV/TNCS, com a produção de 363 blastocistos, obtendo-se uma média de 17,3 embriões por rotina e de $24,0 \%$ de taxa final de blastocisto, conforme descrito na tabela 6.1. Dos 363 embriões PIV/TNCS produzidos no dia 7 de desenvolvimento in vitro, apenas 177 blastocistos foram transferidos a fresco, com a média de 1,6 embriões transferidos por receptora, em um total de 113 transferências, resultando em 34 animais prenhes aos 30 dias de gestação (30,1\%). A tabela 6.2 apresenta os resultados das transferências de embriões clonados considerando-se o número de embriões transferidos por receptora apenas para o grupo TNCS. A transferência de um ou de dois embriões por receptora não influenciou as taxas de prenhez ou de perdas gestacionais, com apenas duas fêmeas gestando gêmeos após a transferência de dois embriões TNCS. Uma destas fêmeas abortou entre os dias 30 e 35, com a outra abortando aos 196 dias de gestação. 
Tabela 6.1 - Resultados de 20 rotinas de produção in vitro de embriões por transferência nuclear de célula somática (TNCS), incluindo a eficiência por etapa obtida e a média por rotina de estruturas trabalhadas e/ou produzidas em cada etapa, Laboratório de Reprodução Animal, UDESC Lages, SC - 2008-2009

\section{Etapas da PIV/TNCS}

\section{Total Média/Rotina}

511,4

COCs colocados em maturação in vitro

10.739

297,3

58,1

polar)

Seleção de hemi-oócitos enucleados $(50 \%$ do citoplasma) por fluorescência

Reconstrução embrionária (reconstituição de $100 \%$ do volume citoplasmático inicial formados por dois hemi-oócitos)

Estruturas fusionadas

Estruturas colocadas em cultivo in vitro

Clivagem

1.094

52,1

72,3

Blastocistos

363

17,3

24,0

Eficiência geral (blastocistos/total de COCs)

$5,1 \%$
Eficiência

por etapa

Independente do número de embriões transferidos por receptora, das 34 prenhezes de clones estabelecidas aos 30 dias de gestação, 50\% (17/34) foram perdidas (fêmeas ciclaram espontaneamente) entre 30-37 dias, cinco abortaram entre 38-51 dias (14,7\%), uma entre 5262 dias $(2,9 \%)$ e outra entre $63-78$ dias $(2,9 \%)$, com um acumulo de 24 perdas no terço inicial de gestação (70,6\%). No segundo terço gestacional, uma fêmea abortou com 150-160 dias $(2,9 \%)$ e duas aos 196 dias (5,9\%). Das gestações que permaneceram viáveis, seis foram abatidas aos 225 dias de gestação, com uma sendo levada a termo, aos 289 dias, com o nascimento por cesariana de uma fêmea bovina pesando $39 \mathrm{~kg}$ (Capítulo 4).

Todas as sete receptoras que mantiveram a gestação até os 225 dias gestavam fêmeas, com o diagnóstico realizado aos 58 dias, sendo re-confirmados ao abate ou ao nascimento. 
Tabela 6.2 - Taxas de prenhez e de perdas gestacionais ao longo da gestação no grupo TNCS com um ou dois embriões transferidos por receptora - Santa Catarina - 2007-2009

\begin{tabular}{|c|c|c|c|c|c|c|c|c|c|c|}
\hline \multirow{3}{*}{$\begin{array}{c}\text { Embriões } \\
\text { por } \\
\text { Receptora }\end{array}$} & \multirow{3}{*}{$\mathbf{T E}^{\S}$} & \multirow{3}{*}{$\begin{array}{c}\text { Embriões } \\
\text { Transferidos }\end{array}$} & \multirow{2}{*}{\multicolumn{2}{|c|}{$\begin{array}{c}\text { Prenhez } \\
\text { Dia } 30 \\
\end{array}$}} & \multicolumn{6}{|c|}{ Perdas Gestacionais Acumuladas ${ }^{*}$} \\
\hline & & & & & \multicolumn{2}{|c|}{ Dia 37} & \multicolumn{2}{|c|}{ Dia 51} & \multicolumn{2}{|c|}{ Dia 225} \\
\hline & & & $\mathbf{n}$ & $\%$ & $\mathbf{n}$ & $\%$ & $\mathbf{n}$ & $\%$ & n & $\%$ \\
\hline Um & 49 & 49 & 16 & 32,7 & 9 & 56,3 & 12 & 75,0 & 12 & 75,0 \\
\hline Dois & 64 & 128 & $18^{\circledR}$ & 28,1 & 8 & 44,4 & 10 & 55,6 & 15 & 83,3 \\
\hline Total & 113 & 177 & 34 & 30,1 & 17 & 50,0 & 22 & 64,7 & 27 & 79,4 \\
\hline
\end{tabular}

${ }^{8}$ Total de transferências

*Baseando-se nas prenhezes iniciais estabelecidas

${ }^{\mathbb{B}}$ Duas gestações gemelares

Os resultados relativos às taxas de prenhez aos 30 dias de gestação e às perdas gestacionais subseqüentes, nos três grupos, são apresentados na tabela 6.3. O grupo Controle apresentou a maior taxa de prenhez, não havendo diferença entre os grupos FIV e TNCS. As perdas gestacionais acumuladas foram semelhantes para os grupos Controle e FIV, em todo o período, sendo significativamente menores que as perdas do grupo TNCS, em todas as fases gestacionais.

Tabela 6.3 - $\quad$ Taxas de prenhez e de perdas gestacionais ao longo da gestação nos grupos Controle, FIV e TNCS - Santa Catarina - 2007-2009

\begin{tabular}{|c|c|c|c|c|c|c|c|c|c|c|c|}
\hline \multirow{3}{*}{ Grupo } & \multirow{3}{*}{$\mathbf{T E}^{\S}$} & \multirow{2}{*}{\multicolumn{2}{|c|}{$\begin{array}{c}\text { Prenhez } \\
\text { Dia } 30 \\
\end{array}$}} & \multicolumn{8}{|c|}{ Perdas Gestacionais Acumuladas ${ }^{*}$} \\
\hline & & & & \multicolumn{2}{|c|}{ Dia 37} & \multicolumn{2}{|c|}{ Dia 51} & \multicolumn{2}{|c|}{ Dia 90} & \multicolumn{2}{|c|}{ Dia 225} \\
\hline & & $\mathbf{n}$ & $\%$ & $\mathbf{n}$ & $\%$ & $\mathbf{n}$ & $\%$ & $\mathbf{n}$ & $\%$ & $\mathbf{n}$ & $\%$ \\
\hline Controle & 12 & 7 & $58,3^{\mathrm{b}}$ & 1 & $14,3^{\mathrm{a}}$ & 1 & $14,3^{\mathrm{a}}$ & 1 & $14,3^{\mathrm{a}}$ & 2 & $28,6^{\mathrm{a}}$ \\
\hline FIV & 22 & 5 & $22,7^{\mathrm{a}}$ & 1 & $20,0^{\mathrm{a}}$ & 1 & $20,0^{\mathrm{a}}$ & 1 & $20,0^{\mathrm{a}}$ & 1 & $20,0^{\mathrm{a}}$ \\
\hline TNCS & 113 & 34 & $30,1^{\mathrm{a}}$ & 17 & $50,0^{\mathrm{b}}$ & 22 & $64,7^{b}$ & 24 & $70,6^{\mathrm{b}}$ & 27 & $79,4^{\mathrm{b}}$ \\
\hline
\end{tabular}

\footnotetext{
$\overline{\mathrm{a}, \mathrm{b}}$ Números com letras desiguais na coluna diferem, $\mathrm{P}<0,05$

${ }^{\S}$ Total de transferências

*Baseando-se nas prenhezes iniciais estabelecidas
}

\subsubsection{Morfometria e Morfologia de Conceptos Bovinos aos 51 Dias de Gestação}

As características mensuradas das imagens ultrasonográficas coletadas de prenhezes aos 51 dias de gestação, nos três grupos experimentais, são apresentadas na tabela 6.4, e 
incluem: freqüência cardíaca, comprimento fetal, da cabeça do feto, da vesícula amniótica e do comprimento e altura dos placentônios encontrados próximos aos fetos. Estes dados referem-se somente a imagens de prenhezes encerradas aos 225 dias.

Tabela 6.4 - Resultados das mensurações dos conceptos dos grupos Controle, FIV e TNCS por ultrasonografia aos 51 dias de gestação (1.s.m. \pm s.e.m.) - Santa Catarina - 2008-2009

\begin{tabular}{lcccc}
\hline \hline & Controle & FIV & TNCS & P $_{\text {grupo }}$ \\
\hline Freqüência Cardíaca (bat/min) & $198,4 \pm 1,5^{\mathrm{b}}$ & $192,7 \pm 3,0^{\mathrm{ab}}$ & $184,0 \pm 1,5^{\mathrm{a}}$ & 0,002 \\
Comprimento Fetal (mm) & $34,3 \pm 1,6^{\mathrm{b}}$ & $38,7 \pm 3,2^{\mathrm{b}}$ & $27,6 \pm 1,6^{\mathrm{a}}$ & 0,028 \\
Comprimento Cefálico (mm) & $15,9 \pm 0,5^{\mathrm{b}}$ & $15,7 \pm 0,9^{\mathrm{b}}$ & $12,3 \pm 0,5^{\mathrm{a}}$ & 0,004 \\
$\begin{array}{l}\text { Comprimento da Vesícula } \\
\text { Amniótica (mm) }\end{array}$ & $47,1 \pm 1,6^{\mathrm{b}}$ & $43,6 \pm 3,1^{\mathrm{ab}}$ & $35,6 \pm 1,6^{\mathrm{a}}$ & 0,006 \\
Comprimento do Placentônio (mm) & $10,4 \pm 0,3^{\mathrm{b}}$ & $10,3 \pm 0,3^{\mathrm{b}}$ & $8,6 \pm 0,3^{\mathrm{a}}$ & $>0,001$ \\
Altura do Placentônio (mm) & $3,3 \pm 0,1^{\mathrm{b}}$ & $3,7 \pm 0,1^{\mathrm{b}}$ & $3,0 \pm 0,1^{\mathrm{a}}$ & $>0,001$ \\
\hline \hline $\mathrm{a}, \mathrm{b}$ Nómmo
\end{tabular}

${ }_{\bar{a}, \mathrm{~b}:}$ Números com letras desiguais na mesma linha diferem, $\mathrm{P}<0,05$

Conforme observado na tabela 6.4, aos 51 dias, os fetos do grupo TNCS foram significativamente menores que o dos outros dois grupos, apresentando batimento cardíaco e comprimento da vesícula amniótica semelhante ao do grupo FIV. Os placentônios do grupo TNCS apresentaram menor comprimento e altura que os dos grupos FIV e Controle, que por sua vez, não diferiram. Interessantemente, a freqüência cardíaca apresentou uma elevada correlação positiva com as outras características mensuradas aos 51 dias, sendo o comprimento da cabeça $(\mathrm{R}=0,809, \mathrm{P}=0,005)$ e o comprimento da vesícula amniótica $(\mathrm{R}=$ $0,826, \mathrm{P}=0,003$ ) as mais expressivas. O comprimento fetal, por sua vez, apresentou uma tendência de se correlacionar positivamente com o comprimento da cabeça $(\mathrm{R}=0,593, \mathrm{P}=$ $0,054)$, mas apresentou uma boa correlação com o comprimento da vesícula amniótica $(\mathrm{R}=$ $0,715, \mathrm{P}=0,013)$.

Correlações negativas $(\mathrm{R}>0,650)$ foram encontras entre as características fetais e o comprimento da vesícula amniótica aos 51 dias, independente do grupo experimental, e as medidas e volumes dos tratos aos 225 dias, incluindo o trato gravídico, o trato vazio, o peso dos placentônios totais, das membranas fetais, do volume dos fluidos totais, do volume do alantóide e do peso fetal. Estas correlações negativas elevadas foram mantidas entre a freqüência cardíaca e o comprimento da cabeça aos 51 dias e diversas mensurações morfométricas aos 225 dias, como o comprimento fetal e da cabeça, da circunferência 
torácica, dos pesos do úmero e do fêmur, dos quatro músculos esqueléticos, dos segmentos tímicos e do coração. Ademais, as medidas fetais e o comprimento da vesícula amniótica aos 51 dias apresentaram esta elevada correlação negativa com o comprimento do esôfago, peso do fígado, do baço, dos rins e das adrenais.

\subsubsection{Morfometria e Morfologia de Conceptos Bovinos aos 225 Dias de Gestação}

Os resultados morfométricos e morfológicos dos conceptos dos três grupos experimentais foram subdivididos quanto ao compartimento pertencente de cada característica avaliada, buscando facilitar a interpretação e apresentação dos dados.

6.3.3.1 Características do Trato Reprodutivo Grávido e seus Componentes aos 225 Dias de Gestação

Aos 225 dias de gestação, as receptoras foram abatidas com condições físicas similares entre os grupos, conforme observado pelo peso vivo, o escore de condição corporal, o peso de carcaça e o rendimento de carcaça (Tabela 6.5). Porém, diferenças entre os tratos reprodutivos foram tangíveis em distintas características, conforme demonstrado na tabela 6.5, com o grupo TNCS apresentando valores maiores que os dos outros dois grupos. Este incremento dos valores numéricos encontrados em cada característica mensurada no grupo TNCS foi da ordem de 2 a 6 vezes ao dos valores obtidos com os outros dois grupos, que por sua vez, foram semelhantes entre si. O peso fetal médio em cada grupo exemplifica este aumento dos valores do grupo TNCS, sendo duas vezes maior que o grupo Controle, e $72 \%$ maior que o grupo FIV (Tabela 6.6), que neste caso específico não diferiu, mas apresentou uma tendência de ser distinto entre os grupos FIV e TNCS $(P=0,065)$. A exceção nestas características foi o número de placentônios no corno uterino gestante, sendo menor no grupo FIV, e similar entre o TNCS e o Controle. 
Tabela 6.5 - Pesos, medidas lineares e volumes de úteros gravídicos de conceptos dos grupos Controle, FIV e TNCS aos $225 \pm 2$ dias de gestação (1.s.m. \pm s.e.m.) - Santa Catarina - 2008-2009

\begin{tabular}{|c|c|c|c|c|}
\hline & Controle & FIV & TNCS & $\overline{\mathbf{P}_{\text {grupo }}}$ \\
\hline Peso vivo da receptora, $\mathrm{kg}$ & $503,3 \pm 19,6^{\mathrm{a}}$ & $456,5 \pm 27,8^{\mathrm{a}}$ & $510,6 \pm 17,6^{\mathrm{a}}$ & 0,299 \\
\hline Peso da carcaça, $\mathrm{kg}$ & $238,0 \pm 12,6^{\mathrm{a}}$ & $216,7 \pm 17,8^{\mathrm{a}}$ & $225,6 \pm 11,2^{\mathrm{a}}$ & 0,602 \\
\hline Rendimento de carcaça, \% & $47,2 \pm 1,5^{\mathrm{a}}$ & $47,6 \pm 2,1^{\mathrm{a}}$ & $44,2 \pm 1,3^{\mathrm{a}}$ & 0,281 \\
\hline Escore Condição Corporal, 1 a $9^{\mp}$ & $7,4 \pm 0,4^{\mathrm{a}}$ & $6,3 \pm 0,6^{\mathrm{a}}$ & $7,1 \pm 0,4^{\mathrm{a}}$ & 0,367 \\
\hline Peso do Trato Gravídico, $\mathrm{kg}^{\dagger}$ & $29,0 \pm 8,0^{\mathrm{a}}$ & $36,7 \pm 11,3^{\mathrm{a}}$ & $76,8 \pm 7,1^{b}$ & 0,005 \\
\hline Peso do Trato Vazio, kg* & $7,5 \pm 1,7^{\mathrm{a}}$ & $8,8 \pm 2,4^{\mathrm{a}}$ & $18,4 \pm 1,5^{b}$ & 0,003 \\
\hline Peso do Útero, $\mathrm{kg}$ & $3,0 \pm 0,6^{\mathrm{a}}$ & $3,0 \pm 0,8^{\mathrm{a}}$ & $4,5 \pm 0,5^{\mathrm{a}}$ & 0,151 \\
\hline Peso das Membranas Fetais, kg & $0,8 \pm 0,8^{\mathrm{a}}$ & $2,0 \pm 1,2^{\mathrm{ab}}$ & $4,8 \pm 0,7^{b}$ & 0,018 \\
\hline Número total de Placentônios & $81,5 \pm 8,9^{\mathrm{a}}$ & $51,0 \pm 12,6^{\mathrm{a}}$ & $72,6 \pm 7,9^{\mathrm{a}}$ & 0,201 \\
\hline $\begin{array}{l}\text { Número de Placentônios - Corno } \\
\text { Prenhe }\end{array}$ & $66,0 \pm 3,8^{b}$ & $44,0 \pm 5,4^{\mathrm{a}}$ & $57,4 \pm 3,4^{\mathrm{ab}}$ & 0,030 \\
\hline $\begin{array}{l}\text { Número de Placentônios - Corno } \\
\text { Não-Prenhe }\end{array}$ & $15,5 \pm 9,0^{\mathrm{a}}$ & $7,0 \pm 12,8^{\mathrm{a}}$ & $15,2 \pm 8,1^{\mathrm{a}}$ & 0,843 \\
\hline Peso total dos Placentônios, $\mathrm{kg}$ & $3,2 \pm 0,5^{\mathrm{a}}$ & $3,3 \pm 0,8^{\mathrm{a}}$ & $6,3 \pm 0,5^{b}$ & 0,004 \\
\hline $\begin{array}{l}\text { Peso dos Placentônios - Corno } \\
\text { Prenhe, kg }\end{array}$ & $2,9 \pm 0,6^{\mathrm{a}}$ & $3,2 \pm 0,9^{\mathrm{a}}$ & $6,2 \pm 0,6^{\mathrm{b}}$ & 0,008 \\
\hline $\begin{array}{l}\text { Peso dos Placentônios - Corno } \\
\text { Não-Prenhe, kg }\end{array}$ & $0,6 \pm 0,3^{\mathrm{a}}$ & $0,2 \pm 0,4^{\mathrm{a}}$ & $0,6 \pm 0,2^{\mathrm{a}}$ & 0,737 \\
\hline $\begin{array}{l}\text { Relação Peso do Feto:Peso total } \\
\text { dos Placentônios }\end{array}$ & $3,9 \pm 0,2^{\mathrm{a}}$ & $4,3 \pm 0,2^{\mathrm{a}}$ & $3,8 \pm 0,2^{\mathrm{a}}$ & 0,245 \\
\hline $\begin{array}{l}\text { Área de Superfície da Placenta, } \\
\mathrm{cm}^{2}\end{array}$ & $2117 \pm 347^{\mathrm{a}}$ & $1525 \pm 347^{\mathrm{a}}$ & $3530 \pm 283^{b}$ & 0,002 \\
\hline Volume dos Fluidos Totais, $\mathrm{L}^{\dagger}$ & $7,8 \pm 8,4^{\mathrm{a}}$ & $9,7 \pm 11,9^{\mathrm{a}}$ & $31,0 \pm 7,5^{\mathrm{a}}$ & 0,146 \\
\hline Volume do Fluido Alantóico, $\mathrm{L}^{\dagger}$ & $3,9 \pm 8,0^{\mathrm{a}}$ & $6,0 \pm 11,3^{\mathrm{a}}$ & $23,6 \pm 7,2^{\mathrm{a}}$ & 0,207 \\
\hline Volume do Fluido Amniótico, $\mathrm{L}^{\dagger}$ & $4,0 \pm 2,9^{\mathrm{a}}$ & $3,7 \pm 4,2^{\mathrm{a}}$ & $7,4 \pm 2,6^{\mathrm{a}}$ & 0,634 \\
\hline Relação Alantóide:Âmnio ${ }^{\dagger}$ & $1,3 \pm 1,3^{\mathrm{a}}$ & $2,5 \pm 1,9^{\mathrm{a}}$ & $5,1 \pm 1,2^{\mathrm{a}}$ & 0,161 \\
\hline
\end{tabular}

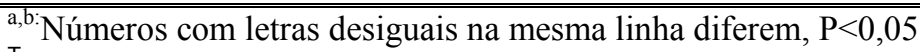

${ }^{\mp}$ Escore de 1 (extremamente magra) até 9 (excessivo acúmulo de gordura)

*Trato uterino sem feto e fluidos, apenas tecido materno, placenta e membranas fetais

${ }^{\dagger}$ Valores do grupo TNCS de apenas cinco animais - informações adicionais encontram-se no texto
} 
Infelizmente, uma das receptoras do grupo TNCS (primeiro animal abatido neste grupo, Clone 1) teve o útero rompido no momento da remoção da cavidade abdominal, pelo excesso de peso e volume do órgão, inviabilizando a inclusão de alguns dados na análise estatística (peso do trato gravídico, volume de fluidos fetais). Este animal apresentou um feto pesando $42 \mathrm{~kg}$, sete quilos a mais do que o segundo maior indivíduo deste grupo, e o maior dos quatorze animais deste experimento. Como os fluidos fetais foram perdidos com a ruptura uterina, restando somente pequenas porções de fluidos misturados em proporções desconhecidas, a mensuração da osmolalidade do fluido alantóide, indicativo de potencial hidroalantóide (WINTOUR; LAURENCE; LINGWOOD, 1986), não serviu como diagnóstico auxiliar.

O peso do trato uterino inteiro apresentou boas correlações com distintas medidas do concepto, incluindo tecidos e órgãos fetais, mas as mais elevadas correlações ocorreram com o volume total de fluidos $(\mathrm{R}=0,908, \mathrm{P}<0,001)$, e o volume do fluido alantóide $(\mathrm{R}=0,841, \mathrm{P}$ $=0,001)$, que por sua vez, apresentaram entre si uma alta correlação $(\mathrm{R}=0,957, \mathrm{P}<0,001)$. De forma interessante, o tecido uterino, quando desprovido de todos os componentes gestacionais, não apresentou diferença entre os grupos e nenhuma correlação significativa com nenhuma outra característica, evidenciando que as diferenças entre grupos ocorreram devido aos componentes fetais, dos fluidos e membranas fetais, e da placenta.

$\mathrm{O}$ peso dos placentônios totais e do corno uterino prenhe apresentaram altas correlações com os volumes, pesos e medidas dos úteros gravídicos e com praticamente todos os pesos e medidas de tecidos e órgãos dos fetos, mas especialmente com o peso fetal per se, cujas correlações foram de $\mathrm{R}=0,976(\mathrm{P}<0,001)$ e $\mathrm{R}=0,911(\mathrm{P}<0,001)$ para o peso dos placentônios totais e do corno uterino prenhe, respectivamente. A relação do peso fetal/peso total dos placentônios não apresentou diferenças entre os grupos. Porém, a área mensurada da placenta foi significativamente maior para o grupo TNCS do que o grupo FIV, com o grupo Controle não diferindo de ambos.

\subsubsection{Características Fetais dos Conceptos aos 225 Dias de Gestação}

Seguindo-se o peso fetal, praticamente todas as medidas e pesos do feto e dos tecidos e órgãos apresentaram uma boa correlação entre si, com as exceções sendo o peso do estômago, do sistema nervoso central, do cérebro, do cerebelo e da hipófíse, e os 
comprimentos da traquéia e das diáfises. A análise de variância revelou que a metade (20/40) das variáveis físicas (pesos e medidas lineares dos fetos e dos tecidos, órgãos e glândulas) apresentou tendência ou mesmo diferenças significativas entre os grupos, em especial entre o TNCS e os grupos FIV e Controle, onde o primeiro apresentou valores maiores do que os outros dois, que normalmente não diferiram entre si, conforme demonstrado nas tabelas $6.6 \mathrm{e}$ 6.7. Porém, após o ajuste estatístico pela comparação por ANCOVA, com o peso fetal utilizado como co-variável, estas diferenças em sua grande maioria desapareceram. Dentre as diversas características avaliadas após a realização da ANCOVA, as diferenças entre os grupos ficaram restritas apenas ao timo torácico que foi menor para ambos os grupos in vitro, e para o comprimento da traquéia e o peso do baço que foram cerca de duas vezes menores para o grupo TNCS em comparação aos grupos Controle e FIV. O peso do intestino total do grupo Controle tendeu a ser maior $(\mathrm{P}=0,078)$ que o grupo TNCS.

Tabela 6.6 - Pesos e medidas lineares de fetos dos grupos Controle, FIV e TNCS aos $225 \pm 2$ dias de gestação (1.s.m. \pm s.e.m.) - Santa Catarina - 2008-2009

\begin{tabular}{lcccc}
\hline \hline & Controle & FIV & TNCS & P grupo \\
\hline Peso Fetal, kg & $12,5 \pm 2,3^{\mathrm{a}}$ & $14,1 \pm 3,2^{\mathrm{ab}}$ & $24,2 \pm 2,0^{\mathrm{b}}$ & 0,011 \\
Comprimento Fetal, cm & $58,3 \pm 2,2^{\mathrm{a}}$ & $59,0 \pm 3,1^{\mathrm{a}}$ & $65,0 \pm 2,0^{\mathrm{a}}$ & 0,107 \\
Comprimento Cefálico, cm & $22,0 \pm 0,4^{\mathrm{a}}$ & $24,5 \pm 0,6^{\mathrm{b}}$ & $25,0 \pm 0,4^{\mathrm{b}}$ & 0,001 \\
Área Óptica, cm & & & & \\
Circunferência Torácica, cm & $48,8 \pm 2,4^{\mathrm{a}}$ & $48,5 \pm 3,4^{\mathrm{a}}$ & $61,1 \pm 2,2^{\mathrm{b}}$ & 0,009 \\
$\begin{array}{l}\text { Comprimento do Membro } \\
\text { Torácico, cm }\end{array}$ & $58,5 \pm 2,6^{\mathrm{a}}$ & $60,0 \pm 3,6^{\mathrm{a}}$ & $60,1 \pm 2,3^{\mathrm{a}}$ & 0,889 \\
$\begin{array}{l}\text { Comprimento do Úmero, cm } \\
\text { Comprimento da Diáfise }\end{array}$ & $13,1 \pm 0,3^{\mathrm{a}}$ & $12,8 \pm 0,4^{\mathrm{a}}$ & $14,1 \pm 0,3^{\mathrm{a}}$ & 0,046 \\
$\begin{array}{l}\text { Umeral, cm } \\
\text { Peso do Úmero, g }\end{array}$ & $7,7 \pm 0,3^{\mathrm{a}}$ & $7,3 \pm 0,4^{\mathrm{a}}$ & $6,9 \pm 0,2^{\mathrm{a}}$ & 0,186 \\
$\begin{array}{l}\text { Comprimento do Membro } \\
\text { Pélvico, cm }\end{array}$ & $87,4 \pm 10,3^{\mathrm{a}}$ & $96,7 \pm 14,6^{\mathrm{ab}}$ & $142,1 \pm 9,2^{\mathrm{b}}$ & 0,010 \\
$\begin{array}{l}\text { Comprimento do Fêmur, cm } \\
\text { Comprimento da Diáfise }\end{array}$ & $15,0 \pm 0,3^{\mathrm{a}}$ & $15,5 \pm 0,4^{\mathrm{a}}$ & $15,9 \pm 0,3^{\mathrm{a}}$ & 0,168 \\
$\begin{array}{l}\text { Femoral, cm } \\
\text { Peso do Fêmur, g }\end{array}$ & $8,2 \pm 0,2^{\mathrm{a}}$ & $8,5 \pm 0,3^{\mathrm{a}}$ & $8,6 \pm 0,2^{\mathrm{a}}$ & 0,588 \\
\hline \hline
\end{tabular}

${ }^{\mathrm{a}, \mathrm{b}}$ Números com letras desiguais na mesma linha diferem, $\mathrm{P}<0,05$ 
Tabela 6.7 - Pesos e medidas lineares de tecidos, órgãos e glândulas de fetos dos grupos Controle, FIV e TNCS aos $225 \pm 2$ dias de gestação (l.s.m. \pm s.e.m.) - Santa Catarina - 2008-2009

\begin{tabular}{|c|c|c|c|c|}
\hline & Controle & $\overline{\text { FIV }}$ & TNCS & 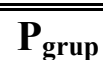 \\
\hline $\begin{array}{l}\text { Peso do Músculo Supra } \\
\text { Espinhoso, g }\end{array}$ & $35,4 \pm 8,9^{\mathrm{a}}$ & $38,3 \pm 12,5^{\mathrm{ab}}$ & $72,6 \pm 7,9^{b}$ & 0,029 \\
\hline $\begin{array}{l}\text { Peso do Músculo Grande } \\
\text { Dorsal, g }\end{array}$ & $223,4 \pm 83,2^{\mathrm{a}}$ & $188,2 \pm 117,6^{\mathrm{a}}$ & $462,0 \pm 74,4^{\mathrm{a}}$ & 0,100 \\
\hline $\begin{array}{l}\text { Peso do Músculo Semi } \\
\text { Tendinoso,g }\end{array}$ & $40,1 \pm 12,1^{\mathrm{a}}$ & $46,9 \pm 17,1^{\mathrm{a}}$ & $111,6 \pm 10,8^{\mathrm{b}}$ & 0,005 \\
\hline $\begin{array}{l}\text { Peso do Músculo Bíceps } \\
\text { Femoral, g }\end{array}$ & $122,4 \pm 31,6^{\mathrm{a}}$ & $131,1 \pm 44,7^{\mathrm{a}}$ & $239,8 \pm 28,3^{\mathrm{a}}$ & 0,049 \\
\hline Peso total do Timo, $\mathrm{g}$ & $77,2 \pm 24,2^{\mathrm{a}}$ & $81,1 \pm 34,3^{\mathrm{a}}$ & $149,9 \pm 21,7^{\mathrm{a}}$ & 0,109 \\
\hline Peso do Timo Cervical, $\mathrm{g}$ & $45,7 \pm 16,0^{\mathrm{a}}$ & $29,6 \pm 22,6^{\mathrm{a}}$ & $96,6 \pm 14,3^{\mathrm{a}}$ & 0,051 \\
\hline Peso do Timo Torácico, g & $31,4 \pm 11,9^{\mathrm{a}}$ & $51,5 \pm 16,8^{\mathrm{a}}$ & $53,3 \pm 10,6^{\mathrm{a}}$ & 0,397 \\
\hline Peso do Coração, g & $99,1 \pm 20,6^{\mathrm{a}}$ & $102,1 \pm 29,1^{\mathrm{ab}}$ & $178,3 \pm 18,4^{\mathrm{b}}$ & 0,041 \\
\hline Peso dos Pulmões, g & $296,5 \pm 23,0^{\mathrm{a}}$ & $316,9 \pm 32,5^{\mathrm{a}}$ & $344,3 \pm 20,6^{a}$ & 0,346 \\
\hline Peso da Traqueia, $g$ & $30,4 \pm 3,1^{\mathrm{a}}$ & $33,4 \pm 4,3^{\mathrm{a}}$ & $40,3 \pm 2,7^{\mathrm{a}}$ & 0,107 \\
\hline Comprimento da Traqueia, $\mathrm{cm}$ & $23,4 \pm 1,2^{\mathrm{a}}$ & $22,7 \pm 1,6^{\mathrm{a}}$ & $22,7 \pm 1,0^{\mathrm{a}}$ & 0,893 \\
\hline Peso do Esôfago, g & $17,6 \pm 3,5^{\mathrm{a}}$ & $12,3 \pm 3,5^{\mathrm{a}}$ & $24,7 \pm 2,2^{\mathrm{a}}$ & 0,057 \\
\hline Comprimento do Esôfago, $\mathrm{cm}$ & $26,6 \pm 1,9^{\mathrm{a}}$ & $28,5 \pm 2,7^{\mathrm{ab}}$ & $34,6 \pm 1,7^{b}$ & 0,033 \\
\hline Peso do Fígado, g & $290,3 \pm 58,2^{\mathrm{a}}$ & $350,7 \pm 82,4^{\mathrm{a}}$ & $396,8 \pm 52,1^{\mathrm{b}}$ & 0,002 \\
\hline Peso do Baço, g & $26,1 \pm 3,9^{\mathrm{a}}$ & $27,4 \pm 5,5^{\mathrm{a}}$ & $47,7 \pm 3,5^{b}$ & 0,006 \\
\hline Peso dos Rins, $\mathrm{g}$ & $69,4 \pm 25,4^{\mathrm{a}}$ & $81,9 \pm 36,0^{\mathrm{a}}$ & $208,9 \pm 22,8^{b}$ & 0,007 \\
\hline Peso do Pâncreas, g & $3,0 \pm 2,0^{\mathrm{a}}$ & $6,0 \pm 2,4^{\mathrm{a}}$ & $8,0 \pm 1,5^{\mathrm{a}}$ & 0,162 \\
\hline Peso do Estômago $^{\dagger}, \mathrm{g}$ & $148,0 \pm 10,5^{\mathrm{a}}$ & $135,0 \pm 12,8^{\mathrm{a}}$ & $173,0 \pm 8,1^{\mathrm{a}}$ & 0,075 \\
\hline Peso total do Intestino, $\mathrm{g}$ & $272,0 \pm 45,4^{\mathrm{a}}$ & $279,0 \pm 55,6^{\mathrm{a}}$ & $376,0 \pm 35,2^{a}$ & 0,196 \\
\hline Peso do Intestino Delgado, $\mathrm{g}$ & $189,0 \pm 23,2^{\mathrm{a}}$ & $184,0 \pm 28,4^{\mathrm{a}}$ & $226,0 \pm 18,0^{\mathrm{a}}$ & 0,365 \\
\hline Peso do Intestino Grosso, g & $83,0 \pm 28,8^{\mathrm{a}}$ & $95,0 \pm 35,3^{\mathrm{a}}$ & $151,0 \pm 22,3^{\mathrm{a}}$ & 0,206 \\
\hline Peso das Gônadas, g & $0,3 \pm 0,1^{\mathrm{ab}}$ & $0,3 \pm 0,1^{\mathrm{a}}$ & $0,5 \pm 0,0^{\mathrm{b}}$ & 0,027 \\
\hline Peso das Adrenais, $\mathrm{g}$ & $1,0 \pm 0,6^{\mathrm{a}}$ & $1,0 \pm 0,7^{\mathrm{ab}}$ & $3,0 \pm 0,4^{\mathrm{b}}$ & 0,029 \\
\hline Peso da Tireóide, $\mathrm{g}$ & $4,0 \pm 0,8^{\mathrm{a}}$ & $6,0 \pm 1,0^{\mathrm{a}}$ & $6,0 \pm 0,7^{\mathrm{a}}$ & 0,246 \\
\hline Peso da Hipófise, g & $0,2 \pm 0,1^{\mathrm{a}}$ & $0,3 \pm 0,1^{\mathrm{a}}$ & $0,2 \pm 0,1^{\mathrm{a}}$ & 0,280 \\
\hline $\begin{array}{l}\text { Peso do Sistema Nervoso } \\
\text { Central, g }\end{array}$ & $136,0 \pm 5,2^{\mathrm{a}}$ & $146,0 \pm 6,3^{\mathrm{a}}$ & $127,0 \pm 4,0^{\mathrm{a}}$ & 0,094 \\
\hline Peso do Cérebro, $\mathrm{g}$ & $120,0 \pm 6,2^{\mathrm{a}}$ & $116,0 \pm 7,6^{\mathrm{a}}$ & $108,0 \pm 4,8^{\mathrm{a}}$ & 0,364 \\
\hline Peso do Cerebelo, $\mathrm{g}$ & $11,0 \pm 0,8^{\mathrm{a}}$ & $10,5 \pm 1,6^{\mathrm{a}}$ & $10,9 \pm 0,7^{\mathrm{a}}$ & 0,957 \\
\hline
\end{tabular}

a,b: Números com letras desiguais na mesma linha diferem, $\mathrm{P}<0,05$

†Inclui Rúmen, Retículo, Omaso e Abomaso 
Os dados das mensurações fetais demonstraram que as medidas e pesos do grupo TNCS foram maiores em valores absolutos, pois o tamanho dos fetos neste grupo também foi maior (Tabela 6.6), mas houve um crescimento relativamente alométrico dos órgãos e tecidos, que em geral acompanharam a proporção do tamanho fetal. Esta observação também fica comprovada após a análise de correlação entre o peso dos fetos com todas as medidas e pesos de seus órgãos e tecidos analisados, cujos valores apresentaram correlações positivas significativas $(\mathrm{R}>0,650)$ entre quase todas as medidas, sendo as exceções o peso do estômago, do sistema nervoso central, do cérebro, do cerebelo e da hipófise, e os comprimentos da traquéia e das diáfises umeral e femoral.

\subsubsection{Características Placentárias dos Conceptos aos 225 Dias de Gestação}

Após a visualização e análise global da placenta em ambos os cornos uterinos, os placentônios foram removidos do útero, classificados individualmente quanto a sua morfologia, seguindo a metodologia descrita, e a freqüência dos tipos de placentônio encontrados apresentada na figura 6.4.

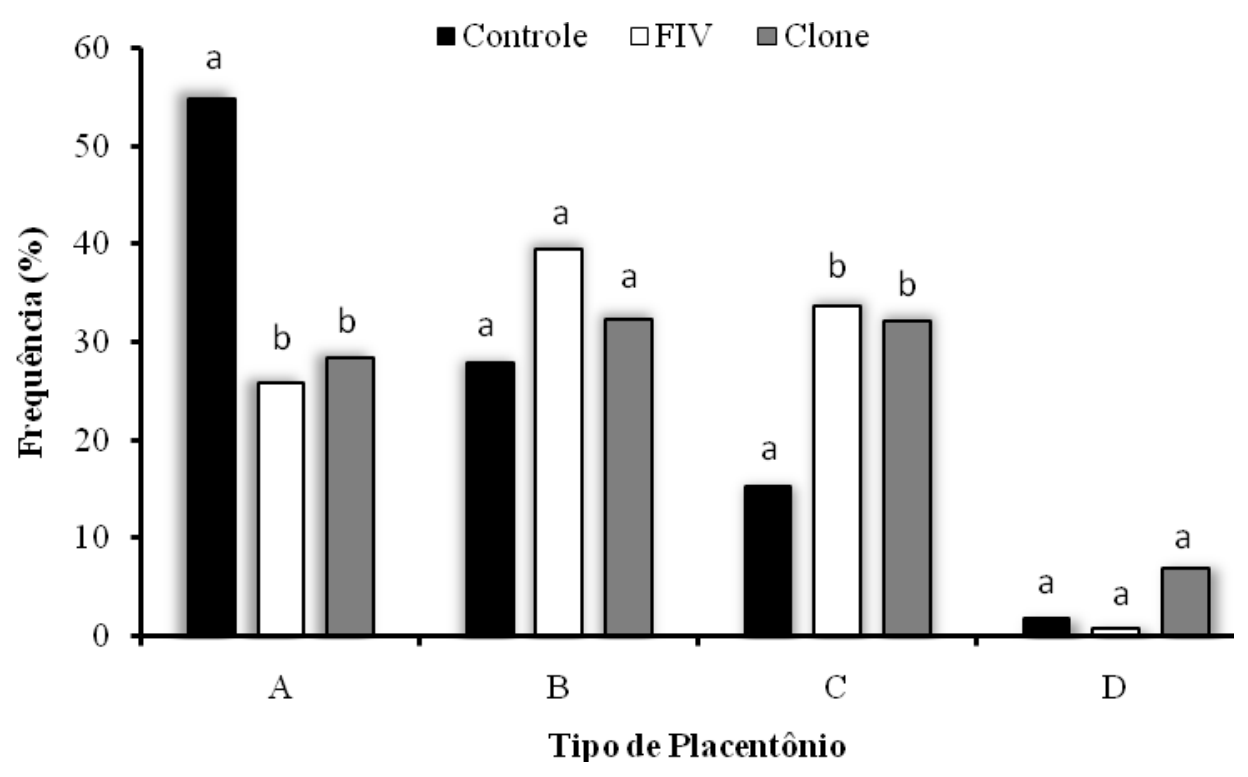

Figura 6.4 - Freqüência de aparecimento dos tipos de placentônio, independente do corno gestante, entre os três grupos (Controle, FIV e TNCS) aos $225 \pm 2$ dias de gestação. ${ }^{\mathrm{a}-\mathrm{b}}$ Dentro de cada tipo, colunas com sobrescritos desiguais diferem, $\mathrm{P}<0,05$ 
Os grupos produzidos in vitro (FIV e TNCS) apresentaram uma freqüência semelhante para cada tipo de placentônio, sendo similares ao grupo Controle nos tipos "B" e "D", e inferiores e superiores ao Controle nos tipos "A" e "C", respectivamente.

Peculiaridades e anormalidades placentárias foram encontradas nos três grupos experimentais. Uma das gestações do grupo controle se encontrava no corno uterino contralateral ao ovário que apresentava o corpo lúteo, e foi a única das quatro que apresentou placentônios do tipo " $\mathrm{D}$ " $(\mathrm{n}=6)$, apresentando também, proporcionalmente, a maior quantidade de placentônios do tipo "C" $(23 / 74,31,1 \%)$. Esta mesma prenhez apresentou microplacentônios em ambos os cornos, bem como uma fusão caruncular. As outras três também apresentaram fusões carunculares (uma por animal), sendo que uma possuía mais de cem microplacentônios no corno não-gestante, aparentando uma placentação adventícia.

No grupo FIV foi encontrada uma elevada freqüência de placentônios tipo "C", e uma quantidade total reduzida de placentônios no corno prenhe (Tabela 6.5). Uma das gestações apresentou, macroscopicamente, edema da placenta, com especial enfoque na região umbilical. Duas prenhezes apresentaram fusões carunculares, sendo que uma destas apresentou microplacentônios em ambos os cornos.

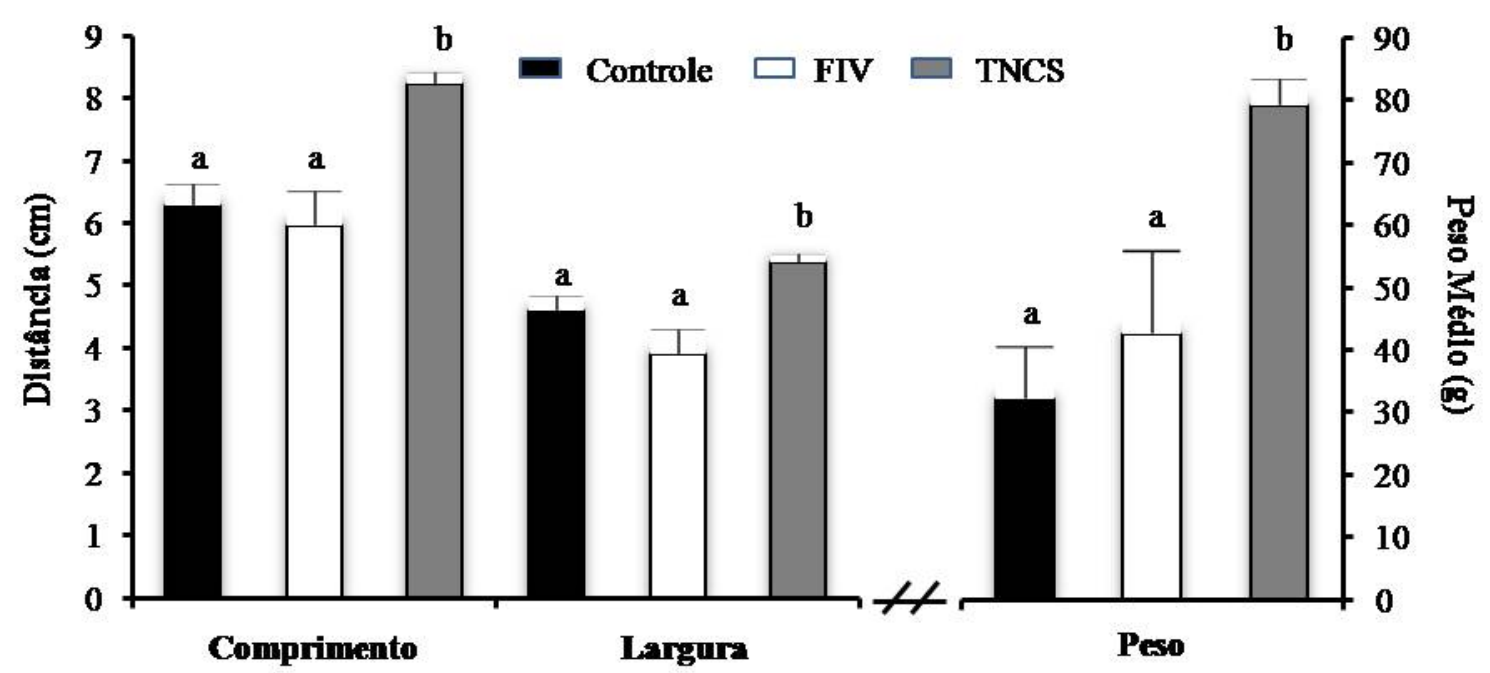

Figura 6.5 - Comprimento, largura e peso médio dos placentônios, independente do corno gestacional, nos

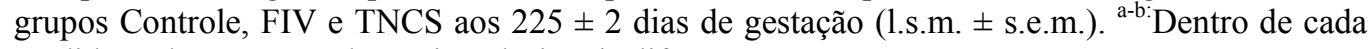
medida, colunas com sobrescritos desiguais diferem, $\mathrm{P}<0,05$

Em geral, conforme ilustrado na figura 6.5, o grupo TNCS apresentou as maiores dimensões (comprimento e largura) e o maior peso médio de placentônios. Independente do corno gestante, a freqüência do comprimento dos placentônios entre os grupos diferiu apenas nos placentônios com 1 e $13 \mathrm{~cm}$ de comprimento, com o grupo FIV apresentando mais 
placentônios pequenos $(1 \mathrm{~cm})$, enquanto que o grupo TNCS apresentou um número maior de placentônios com $13 \mathrm{~cm}$ de diâmetro (Figura 6.6). Analisando-se apenas o corno prenhe, o grupo TNCS apresentou uma tendência $(\mathrm{P}=0,060)$ da curva de freqüência ser diferente do grupo Controle, com um desvio evidente à direita e um estreitamento da curva no grupo TNCS.

Duas prenhezes de cada grupo não apresentaram placentônios no corno uterino nãoprenhe, com apenas as membranas fetais se estendendo de forma variável no corno uterino não-prenhe. O grupo TNCS apresentou os maiores valores para as dimensões (comprimento e largura) e peso dos placentônios no corno uterino prenhe, diferindo dos grupos Controle e FIV, os quais foram semelhantes entre si (Figura 6.7). Em geral, os valores para as três características mensuradas no corno não-prenhe foram inferiores aos do corno prenhe, com o comprimento e peso médio dos placentônios do grupo TNCS no corno não-prenhe sendo semelhantes aos grupos Controle e FIV no corno prenhe.

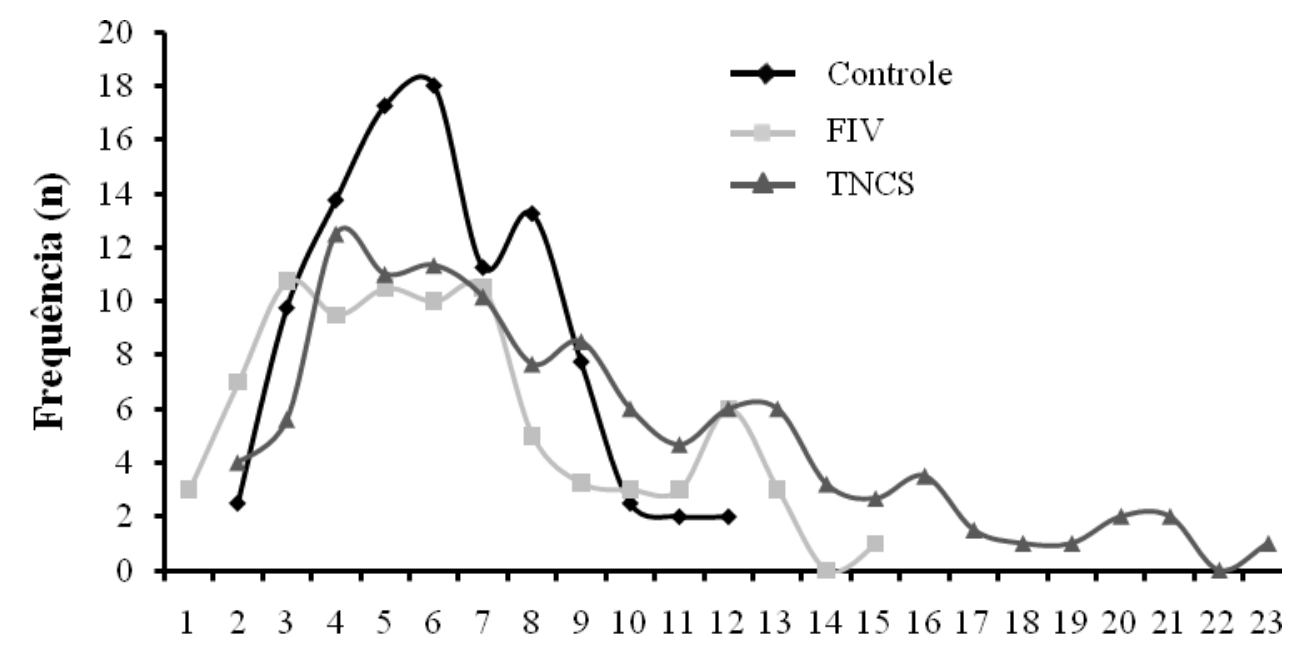

Comprimento dos Placentônios (cm)

Figura 6.6 - Freqüência (n) do comprimento médio (cm) apresentado por todos os placentônios de ambos os cornos uterinos, dos grupos Controle, FIV e TNCS aos $225 \pm 2$ dias de gestação

Conforme esperado, uma elevada correlação positiva foi observada entre $\mathrm{o}$ comprimento $(\mathrm{R}=0,841, \mathrm{P}=0,000)$, a largura $(\mathrm{R}=0,844, \mathrm{P}=0,000)$ e o peso dos placentônios, independente do tipo e do grupo experimental. Entre os diferentes tipos de placentônios, o tipo "D” apresentou a maior dispersão nos valores de comprimento, largura e peso, independente do grupo, conforme observado na figura 6.8. Em geral, avaliando-se do tipo "A" ao "D", os placentônios, independente do grupo, apresentaram uma diminuição nas dimensões (comprimento e largura) e peso, com o grupo TNCS apresentando os maiores valores para estas três características, dentro de cada tipo de placentônio. 
(A)
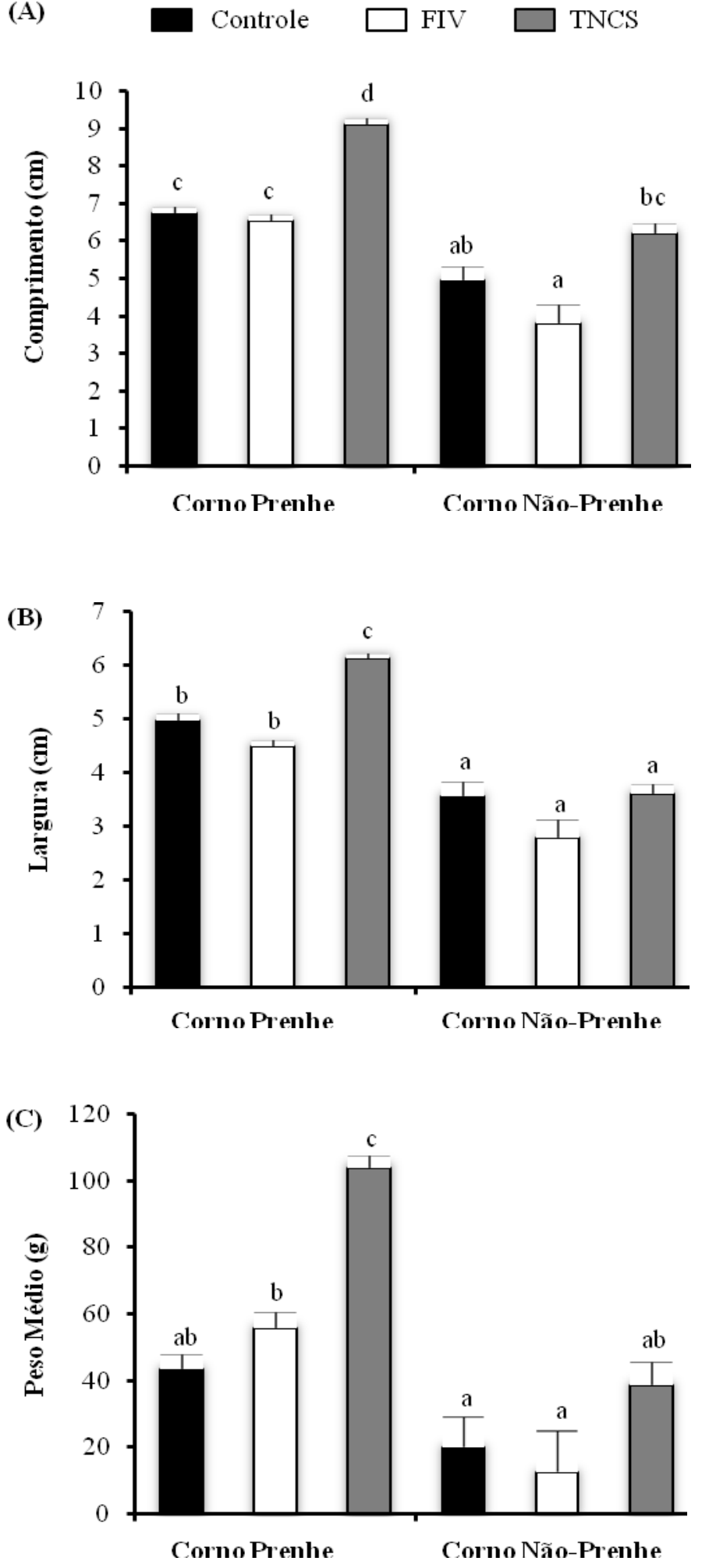

Figura 6.7 - Comprimento (A), largura (B) e peso (C) médio dos placentônios nos cornos uterinos prenhe e não-prenhe nos grupos experimentais (Controle, FIV e TNCS) aos $225 \pm 2$ dias de gestação (1.s.m. \pm s.e.m.). ${ }^{\text {a-d }}$ Colunas com sobrescritos desiguais diferem, $\mathrm{P}<0,05$ 


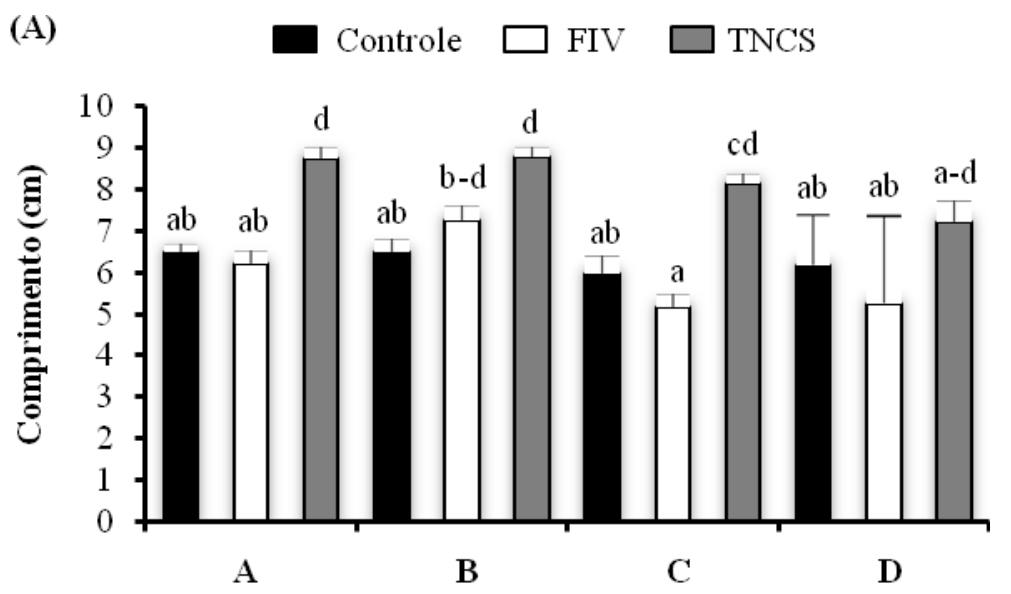

Tipo de Placentônio

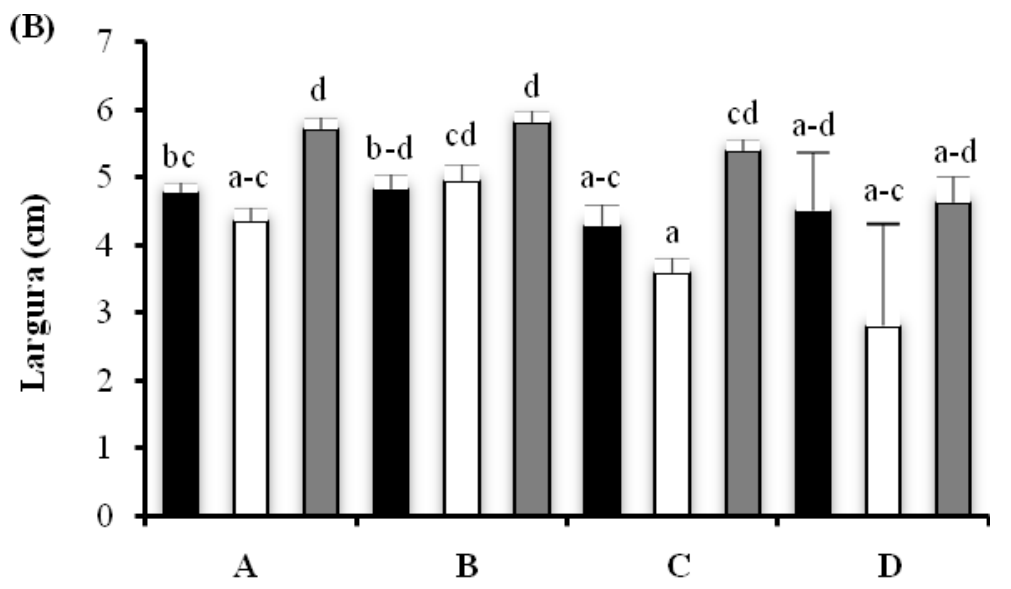

Tipo de Placentônio

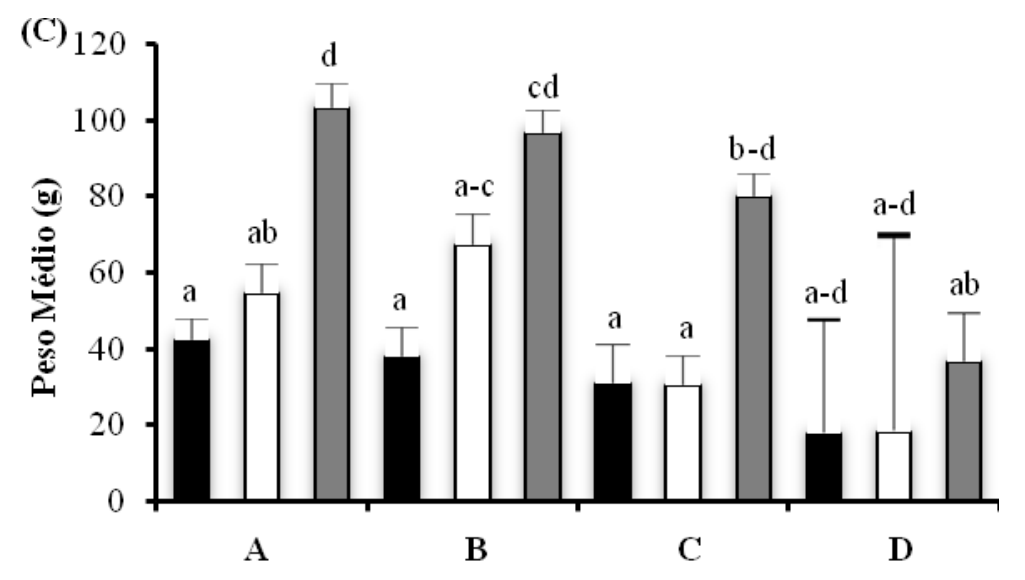

Tip o de Placentônio

Figura 6.8 - Comprimento (A), largura (B) e peso (C) médio dos placentônios por tipo de placentônio, nos grupos experimentais (Controle, FIV e TNCS) aos $225 \pm 2$ dias de gestação (1.s.m. \pm s.e.m.). ${ }^{\text {a- }}$ ¿:Colunas com sobrescritos desiguais diferem, $\mathrm{P}<0,05$ 
6.3.3.4 Particularidades Morfo-Patológicas Macroscópicas de Conceptos do Grupo TNCS aos 225 Dias de Gestação

As maiores alterações macroscópicas estavam presentes nos conceptos do grupo TNCS, com cada animal apresentando alterações peculiares. Na tabela 6.8 estão apresentadas as particularidades de cada uma das seis gestações deste grupo, priorizando as principais alterações encontradas na placenta e no feto de cada indivíduo, com os animais sendo numerados por ordem cronológica de coleta aos 225 dias. 
Tabela 6.8 - Particularidades morfo-patológicas macroscópicas de conceptos do grupo TNCS aos 225 dias de gestação - Santa Catarina - 2008-2009

\begin{tabular}{|c|c|c|c|c|c|c|c|c|c|}
\hline Feto & $\begin{array}{c}\text { Peso } \\
\text { Fetal } \\
(\mathbf{k g})\end{array}$ & $\begin{array}{c}\text { Peso } \\
\text { Trato Gravídico } \\
\text { (kg) }\end{array}$ & $\begin{array}{c}\text { Volume } \\
\text { Alantóide (L) }\end{array}$ & $\begin{array}{l}\text { Volume } \\
\text { Âmnio (L) }\end{array}$ & $\begin{array}{l}\text { Quantidade } \\
\text { Placentônios }\end{array}$ & $\begin{array}{l}\text { Placentônios } \\
\text { Gigantes }^{\mathbf{T}}\end{array}$ & $\begin{array}{c}\text { Fusões } \\
\text { Carunculares }\end{array}$ & $\begin{array}{l}\text { Alterações da } \\
\text { Placenta }\end{array}$ & Alterações do Feto \\
\hline Clone 1 & 42 & $*$ & $*$ & $*$ & 115 & 12 & 1 & $\begin{array}{l}\text { Edema das } \\
\text { Membranas }\end{array}$ & $\begin{array}{l}\text { Aumento do cordão umbilical } \\
\text { e anormalidades hepáticas }\end{array}$ \\
\hline Clone 2 & 22 & 110 & 63 & 8 & 104 & 11 & 6 & $\begin{array}{l}\text { Edema das } \\
\text { Membranas }\end{array}$ & 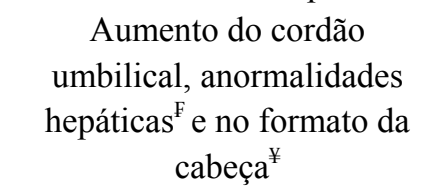 \\
\hline Clone 3 & 35 & 80 & 17 & 3,5 & 57 & 14 & 1 & $\begin{array}{l}\text { Mixedema das } \\
\text { Membranas }^{£}\end{array}$ & $\begin{array}{c}\text { Aumento do cordão umbilical } \\
\text { e contraturas dos tendões } \\
\text { flexores distais }\end{array}$ \\
\hline Clone 4 & 18,3 & 64,5 & 22 & 2,5 & 82 & 7 & 6 & $\begin{array}{l}\text { Mixedema das } \\
\text { Membranas }^{£}\end{array}$ & $\begin{array}{c}\text { Aumento do cordão } \\
\text { umbilical, anormalidades } \\
\text { hepáticas }^{\mathrm{F}} \text {, renais }{ }^{\epsilon} \text { e no } \\
\text { formato da cabeça }\end{array}$ \\
\hline Clone 5 & 23,5 & 50 & 6,4 & 2 & 70 & 8 & 4 & $\begin{array}{l}\text { Edema das } \\
\text { Membranas }\end{array}$ & $\begin{array}{c}\text { Aumento do cordão umbilical } \\
\text { e contraturas dos tendões } \\
\text { flexores distais }\end{array}$ \\
\hline Clone 6 & 22,5 & 80 & 10 & 21 & 50 & 7 & - & $\begin{array}{l}\text { Mixedema das } \\
\text { Membranas }^{£}\end{array}$ & Aumento do cordão umbilical \\
\hline
\end{tabular}

${ }^{\mathrm{T}}$ Placentônios medindo mais de $13 \mathrm{~cm}$ e pesando mais de $250 \mathrm{~g}$

* Não mensurado por rompimento do útero no momento da retirada da cavidade abdominal

†Vasos sanguíneos mais superficiais no parênquima hepático, visíveis e ressaltados na túnica serosa. Túnica serosa da vesícula biliar apresentando-se edemaciada

${ }^{\mathrm{F}}$ Parênquima friável, e presença de sangue no espaço entre a serosa e o parênquima

¥O formato da cabeça fetal apresentou um aspecto "equiniforme", com um aparente prolongamento da região facial

${ }^{\mathfrak{E}}$ Intenso edema das membranas (mixedema), concedendo uma aparência gelatinosa e obscurecendo a visualização de alguns placentônios da vista fetal da placenta, especialmente na região umbilical

${ }^{€}$ Cápsula renal mais aderida ao parênquima que o normal, com a superfície áspera. A pelve renal e ureteres apresentavam-se aumentados 


\subsubsection{Mensurações de Carboidratos no Plasma Materno e Fetal e nos Fluidos Fetais de Conceptos aos 225 Dias de Gestação}

As concentrações de glicose e frutose nos grupos Controle, FIV e TNCS não diferiram dentro de cada tipo de plasma ou fluido analisado (Figura 6.9). Para a glicose, conforme o esperado, as concentrações maternas foram superiores às demais do concepto, independente do grupo, enquanto que para a frutose, os valores no plasma materno mostraram-se extremamente baixos quando comparados aos valores nos fluidos fetais, em especial no alantóide, conforme antecipado.
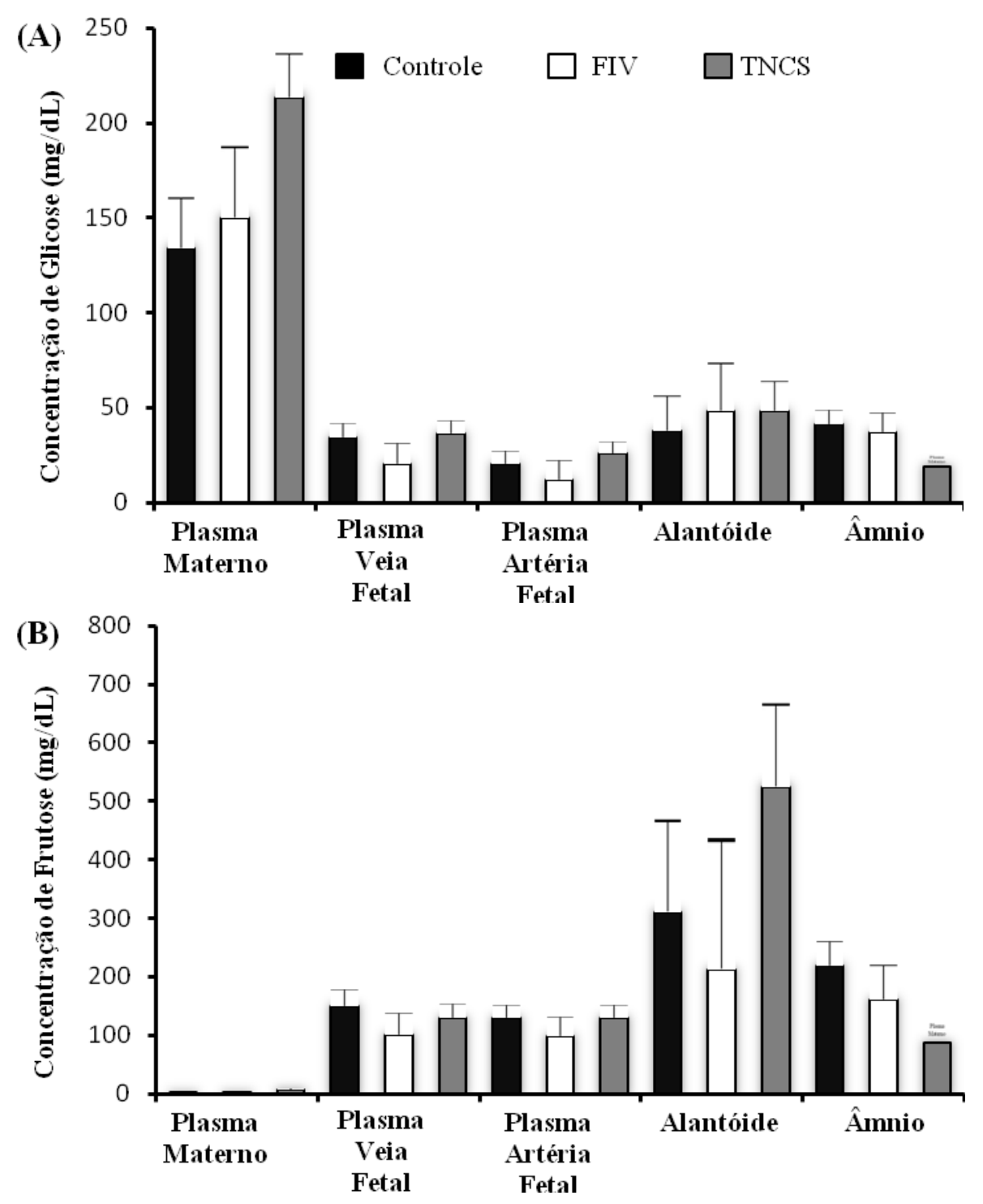

Figura 6.9 - Concentração $(\mathrm{mg} / \mathrm{dL})$ de glicose $(\mathrm{A})$ e frutose $(\mathrm{B})$ nos plasmas materno e fetais, e fluidos fetais de fêmeas prenhes de fetos dos grupos Controle, FIV e TNCS aos $225 \pm 2$ dias de gestação (l.s.m. \pm s.e.m.) 
Os grupos Controle, FIV e TNCS não diferiram para a diferença de concentração de glicose entre a veia e artéria fetal, conforme demonstrado na figura 6.10. Entretanto, para a diferença de concentração de frutose, o grupo TNCS apresentou uma média negativa e significativamente menor que o Controle, mas não ao FIV. Este valor negativo mostra que a concentração de frutose na artéria fetal, para este grupo, foi maior que o da veia.

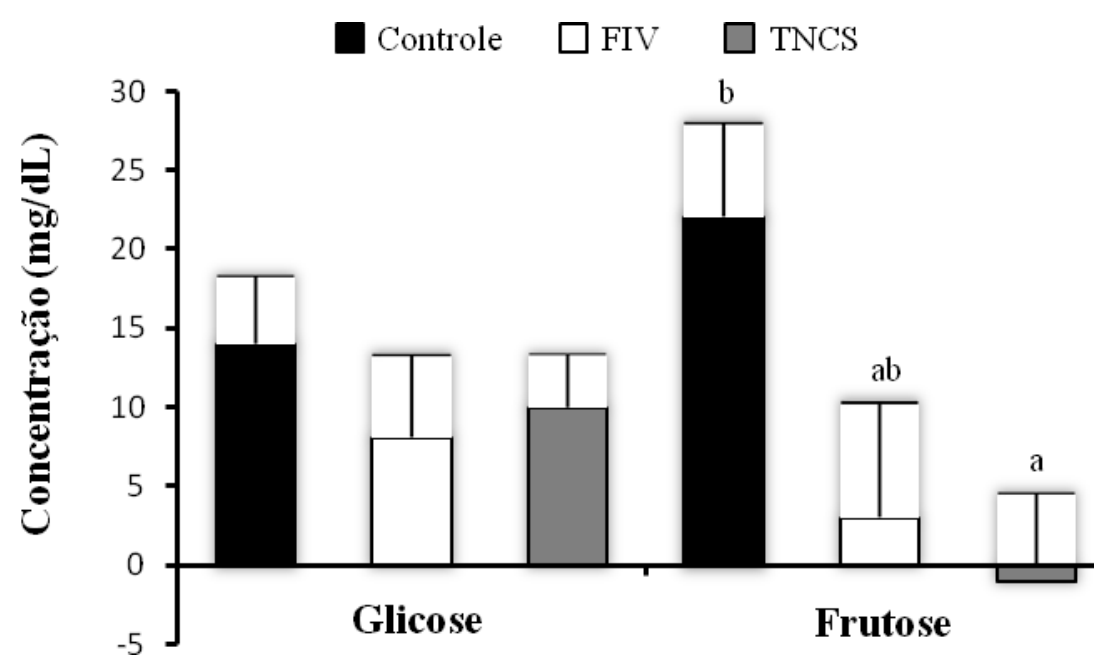

Figura 6.10 - Diferença veno-arterial (V-A) de concentração (mg/dL) de glicose e frutose entre os plasmas da veia e artéria fetais de fêmeas prenhes de fetos dos grupos Controle, FIV e TNCS aos $225 \pm 2$ dias de gestação (1.s.m. \pm s.e.m.). ${ }^{\text {a-b: }}$ Dentro de cada carboidrato, colunas com sobrescritos desiguais diferem, $\mathrm{P}<0,05$

A quantidade total de glicose, conforme demonstrado na figura 6.11, não diferiu entre os grupos em cada fluido e para o total de glicose em ambos os fluidos (alantóide+âmnio). A frutose, no entanto, apresentou uma quantidade total significativa aumentada no alantóide para o grupo TNCS em relação ao Controle, mas que não diferiu do FIV, apesar de haver uma tendência estatística $(P=0,070)$. Ainda, a quantidade total de frutose em ambos os fluidos não diferiu entre os grupos, mas o grupo TNCS apresentou uma tendência de ser maior que o Controle $(\mathrm{P}=0,084)$. No fluido alantóico, a quantidade de glicose + frutose foi maior para o grupo TNCS em relação ao Controle, mas que não foi diferente do FIV. Para ambos os fluidos (alantóide+âmnio), a quantidade total de glicose + frutose não diferiu entre os grupos, apesar da tendência apresentada pelo grupo TNCS de ser maior que o Controle $(\mathrm{P}=0,082)$. Obviamente, quanto maior o volume total de fluidos, maior a quantidade total de glicose+frutose observada no alantóide $(\mathrm{R}=0,946, \mathrm{P}=0,000)$ e em ambos os fluidos $(\mathrm{R}=$ $0,907, \mathrm{P}=0,000)$. 

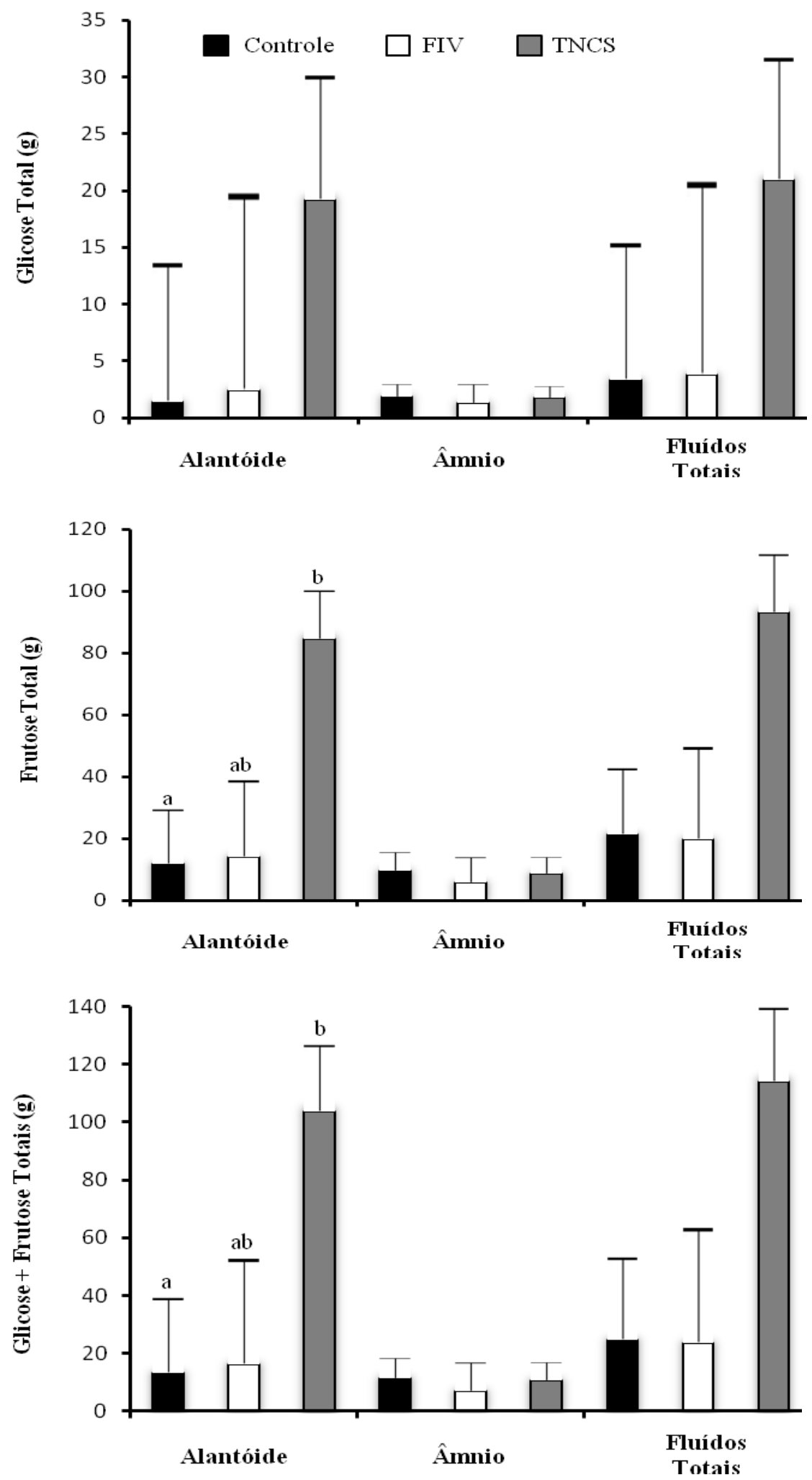

Figura 6.11 - Quantidade total (g) de glicose (A), frutose (B) e de glicose+frutose (C) nos fluidos fetais de fêmeas prenhes de fetos dos grupos Controle, FIV e TNCS aos $225 \pm 2$ dias de gestação (1.s.m. \pm s.e.m.). ${ }^{\mathrm{a}-\mathrm{b}}$ : Dentro de cada fluido, colunas com sobrescritos desiguais diferem, $\mathrm{P}<0,05$ 
A osmolalidade mensurada nos plasmas materno e fetal e nos fluidos fetais não diferiu entre os grupos (Tabela 6.9). Entretanto, o grupo TNCS apresentou uma tendência de uma maior osmolalidade no plasma materno do que nos grupos FIV $(\mathrm{P}=0,077)$ e Controle $(\mathrm{P}=$ 0,097), e maior no plasma da veia fetal do que o grupo FIV $(P=0,076)$.

Tabela 6.9 - Resultados das mensurações da osmolalidade $(\mathrm{mOsm} / \mathrm{Kg})$ dos plasmas maternos e fetais, e fluidos fetais de fêmeas prenhes de fetos dos grupos Controle, FIV e TNCS aos $225 \pm 2$ dias de gestação (1.s.m. \pm s.e.m.) - Santa Catarina - 2008-2009

\begin{tabular}{lcccc}
\hline \hline & Controle & FIV & TNCS & P $_{\text {grupo }}$ \\
\hline Plasma Materno & $295,5 \pm 3,8$ & $294,8 \pm 3,8$ & $307,4 \pm 3,4$ & 0,053 \\
Plasma Veia Fetal & $291,8 \pm 3,6$ & $290,8 \pm 3,6$ & $302,6 \pm 3,2$ & 0,055 \\
Plasma Artéria Fetal & $293,0 \pm 4,6$ & $291,8 \pm 4,6$ & $303,6 \pm 4,1$ & 0,147 \\
Alantóide & $253,7 \pm 6,9$ & $253,1 \pm 6,9$ & $260,6 \pm 6,1$ & 0,667 \\
Âmnio & $267,5 \pm 5,8$ & $266,3 \pm 5,8$ & $282,0 \pm 5,2$ & 0,120 \\
\hline \hline
\end{tabular}

\subsection{DISCUSSÃO}

A produção de 2,3 embriões in vivo (Controle) por sessão de coleta foi baixa e três vezes menor que o número obtido em trabalhos recentes no Brasil com fêmeas zebuínas (PEIXOTO et al., 2006; PONTES et al., 2009). Entretanto, neste experimento, não ocorreu uma seleção prévia das melhores doadoras de embrião dentro de um grupo de animais, um importante fator biológico que propicia um aumento na média dos embriões produzidos em programas reprodutivos (HASLER, 1992). Esta menor quantidade de embriões viáveis obtidos também pode ser explicada pela elevada porcentagem de estruturas degeneradas encontradas $(42,9 \%, 12 / 28)$. Neste caso, não sabemos ao certo o real motivo para esta elevada taxa de embriões inviáveis, podendo haver ocorrido um possível estresse térmico ou alteração no manejo ou na alimentação dos animais no período do trabalho que possa ter afetado negativamente a qualidade embrionária, conforme já demonstrado por Benyei et al. (2006).

Similarmente ao grupo Controle, não houve uma seleção prévia das dez fêmeas que passaram pelos procedimentos de OPU para a posterior produção in vitro de embriões. Porém, o número de oócitos viáveis por aspiração não foi diferente do obtido por Pontes et al. (2009). 
Não obstante, a produção in vitro de embriões neste experimento foi significativamente reduzida, alcançando-se uma taxa de apenas 6,0\% em comparação a 41,4\% obtida naquele estudo. Alguns fatores colaboraram para este baixo resultado; em primeira instância, não ocorreu uma seleção das melhores doadoras do rebanho; em segundo, e provável motivo, dos cinco procedimentos de PIV/FIV de embriões realizados, dois apresentaram uma produção embrionária nula. Nestas duas rotinas, a instabilidade na temperatura da incubadora utilizada para realizar o cultivo foi a provável causa do resultado negativo. Uma terceira possibilidade possa ser decorrente da baixa qualidade dos CCOs obtidos após as aspirações. Como a bomba de vácuo utilizada não era específica para esta finalidade, a manutenção da pressão ao longo do procedimento não foi mantida de forma adequada, prejudicando os CCOs recolhidos. Por último, mas não menos importante, seria a reduzida competência do touro em produzir embriões in vitro. Esta competência individual de cada pai e a interação existente entre macho/fêmea já foram demonstradas ser significativas em outros estudos (PALMA; SINOWATZ, 2004). Como o mesmo touro foi utilizado para a produção in vitro e in vivo de embriões, e por este touro não ter sido testado anteriormente, não é possível afirmar, até o presente momento se as baixas taxas de produção de embriões viáveis obtidas por ambos os grupos (Controle e FIV) também não tenham sofrido a influência deste componente.

A produção in vitro de embriões por TNCS apresentou uma taxa de desenvolvimento embrionária final satisfatória, com $24,0 \%$ dos presumíveis zigotos tornando-se blastocistos nas vinte rotinas realizadas para a transferência dos mesmos. Este valor encontra-se dentro do intervalo aceitável para a produção in vitro deste tipo de embrião, conforme revisado por Vajta et al. (2005), onde os diferentes grupos de pesquisa alcançaram taxas de 0 a $50 \%$ de produção de embriões, com a maioria dos resultados entre 20 e $40 \%$. De maneira geral, o objetivo destas produções tanto in vivo quanto in vitro de embriões não foi o de comparar sistemas de produção, mas sim o de estabelecer um número mínimo de prenhezes que mantivessem a gestação até o terço final nos três grupos experimentais. Sendo assim, apesar das menores taxas de produção de embriões nos grupos Controle e FIV, apenas duas e cinco sessões, utilizando sete e vinte e oito animais, respectivamente, foram necessários para que quatro gestações de ambos os grupos chegassem aos 225 dias, enquanto que vinte procedimentos de PIV/TNCS, com 177 embriões transferidos em 113 transferências, foram necessários para que sete gestações alcançassem os 225 dias neste grupo, permitindo-se que apenas uma delas chegasse a termo (Capítulo 4).

Estes números (procedimentos, embriões, transferências) consideravelmente maiores para o grupo TNCS foram obtidos levando-se em consideração as já esperadas menores taxas 
de prenhez e maiores perdas gestacionais para este grupo, conforme descrito anteriormente e revisado por Bertolini et al. (2007). A taxa de prenhez de 30,1\% foi menor que a do grupo Controle, mas similar a do grupo FIV e da obtida em outros estudos (KATO; TANI; TSUNODA, 2000; BATCHELDER et al., 2005; CHAVATTE-PALMER et al., 2006; PANARACE et al., 2007). Distintos pesquisadores relataram perdas gestacionais da ordem de $75 \%$ até os 58 dias em prenhezes oriundas de embriões produzidos por TNCS (WELLS; MISICA; TERVIT, 1999; HILL et al., 2000; HEYMAN et al., 2002; BATCHELDER et al., 2005; PANARACE et al., 2007). Neste trabalho, 70,6\% (24/34) das perdas ocorreram até os 90 dias, e 79,4\% (27/34) até os 225 dias, com os grupos Controle e FIV apresentando perdas significativamente menores e similares entre si até o terço final de gestação $(28,6$ e 20,0\%, respectivamente). É fato interessante percebermos que a taxa de sucesso/insucesso na gestação inverte-se completamente entre estes grupos.

As elevadas perdas gestacionais, com ênfase especial nos primeiros 51 dias $(64,7 \%$, 22/34), sugerem uma falha no desenvolvimento e/ou estabelecimento da placenta, promovida pelo emprego da TNCS. Esta mortalidade embrionária/fetal mais elevada parece estar associada ao crescimento retardado dos conceptos no início da gestação (BERTOLINI et al., 2002a). Esta afirmação baseia-se nos trabalhos de outros pesquisadores (HILL et al., 2000; DE SOUSA et al., 2001; HASHIZUME et al., 2002), que observaram grosseiras alterações morfológicas na placenta de clones, com reduzida vascularização e desenvolvimento do corioalantóide, e de elevadas taxas de mortalidade no primeiro quarto da gestação. Ainda, utilizando a ultrasonografia como ferramenta de análise das distintas características de conceptos bovinos no primeiro trimestre de gestação, Bertolini et al. (2002a) e ChavattePalmer et al. (2006), comparando gestações Controle e FIV, e Controle e Clones, respectivamente, verificaram que os fetos dos grupos in vitro apresentavam menor tamanho até os 65 (BERTOLINI et al., 2002a) e 62 dias (CHAVATTE-PALMER et al., 2006). Estes achados corroboram com os deste trabalho, que apesar de ter realizado a mensuração em apenas um único momento (dia 51) da gestação, apresentou resultados semelhantes no mesmo dia dos demais estudos. O comprimento da cabeça também foi analisado por Chavatte-Palmer et al. (2006), encontrando valores muito próximos aos deste experimento, com 15,0 e 13,6 mm para os grupo Controle e TNCS, respectivamente, e 15,9 e 12,3 para este experimento, sendo significativamente maior no grupo Controle em ambos os trabalhos. Placentônios de menor tamanho encontrados no grupo TNCS, neste estudo, corroboram com os resultados obtidos por Chavatte-Palmer et al. (2006), que encontraram placentônios mais largos nos animais do grupo controle, mas não mais compridos. Bertolini et al. (2002a) não observaram 
placentônios menores nesta fase, na verdade, esta redução do tamanho ocorreu aos 37 dias no grupo FIV, invertendo-se aos 51 dias, com o grupo FIV sendo maior que o Controle neste momento, o que não ocorreu neste trabalho, onde ambos os grupos foram similares. Como as mensurações foram realizadas em um único dia, não foi possível averiguar a cinética de desenvolvimento dos placentônios, mas observando os valores encontrados nos sonogramas analisados, e as elevadas perdas gestacionais no grupo TNCS, é possível afirmar que uma falha no desenvolvimento da placenta tenha ocorrido também nos clones deste experimento, acarretando em um retardo no crescimento inicial dos fetos deste grupo.

De forma interessante, os batimentos cardíacos por minuto do grupo TNCS foram menores que os do Controle, com os do grupo FIV sendo similar a ambos. Estes resultados contradizem os encontrados por Bertolini et al. (2002a), onde os fetos do grupo FIV apresentaram freqüências cardíacas maiores que os do grupo Controle dos 44 aos 93 dias de gestação, justificando este incremento a um aumento da resistência vascular e da pressão sanguínea decorrentes de uma angiogênese anormal e de uma possível hipoplasia do alantóide, resultando em um quadro de hipóxia e de restrição de desenvolvimento. Neste trabalho, porém, nenhuma alteração macroscópica vascular, cardíaca ou pulmonar foi observada no grupo TNCS aos 225 dias. Contudo, um dos fetos do grupo TNCS abortado aos 196 dias apresentou um orifício no septo interventricular. Esta redução na freqüência cardíaca do grupo TNCS é difícil de ser explicada, talvez, os 22 dos 34 (64,7\%) conceptos perdidos até o dia 51 apresentassem freqüências maiores, com presença de graves alterações no aparelho cardiorespirátório, resultando na morte destes indivíduos, reduzindo a freqüência deste grupo.

No geral, as características fetais mensuradas aos 51 dias de gestação apresentaram elevadas correlações entre si, e de forma muito interessante, demonstraram altas correlações negativas com distintas medidas e volumes dos tratos gestantes e mensurações do feto, incluindo os tecidos e órgãos coletados aos 225 dias. Nestas correlações negativas, o peso fetal se sobressai como uma importante relação entre o tamanho dos conceptos no início da gestação e o tamanho do feto em seu final, demonstrando a existência de um crescimento bifásico dos fetos produzidos in vitro, e em especial dos clones, onde um crescimento retardado nos primeiros dois meses de gestação promove um desenvolvimento compensatório na segunda metade, particularmente no terço final. Este crescimento bifásico já foi demonstrado com o auxílio de ultrasom em animais FIV por Bertolini et al. (2002a), cujas imagens de conceptos FIV revelaram indivíduos significativamente menores nos primeiros dois meses, mas que resultaram em neonatos com um tamanho 33\% maior ao dos controles. Chavatte-Palmer et al. (2006) com o auxílio do ultrasom no início da gestação também 
demonstraram este crescimento deturpado em clones, e mostraram que quando este retardo é exacerbado, os conceptos não conseguem se manter vivos e morrem até o fim do primeiro trimestre, visto que naquele estudo, os conceptos com menor tamanho até os 62 dias efetivamente morreram até os 90 dias de gestação. Este retardo no crescimento está presente antes mesmo da implantação do embrião no útero materno, embriões FIV com 16 dias de gestação apresentaram trofoblastos mais curtos e menores discos embrionários do que embriões produzidos in vivo (BERTOLINI et al., 2002b). Entretanto, este retardo no crescimento parece ficar restrito até o início do terceiro mês, visto que diversos estudos não apontaram diferenças morfométricas entre conceptos in vivo e in vitro dos 70 aos 100 dias (FARIN; FARIN; MUNGAL, 1997; BERTOLINI et al., 2002a, 2004; LEE et al., 2004). Os estudos de Bertolini et al. (2002a), de Chavatte-Palmer et al. (2006) e os resultados deste trabalho, comprovam que as mensurações ultrasonográficas referentes às características dos conceptos produzidos in vitro, nos primeiros dois meses gestacionais de bovinos, podem predizer algumas alterações que compõe a síndrome dos neonatos anormais no terço final da gestação, como o aumento do peso fetal, do trato gravídico, da placenta e do volume dos fluidos totais. Este procedimento de exame apresenta-se como uma ferramenta auxiliar no diagnóstico destas alterações, sendo de grande valia nos programas comerciais de produção in vitro de embriões, seja por FIV ou TNCS, auxiliando no manejo e acompanhamento clínico das receptoras que gestam este tipo de embrião.

A placenta em gestações produzidas in vitro de várias espécies pode apresentar graves alterações morfológicas, histológicas, moleculares e de expressão gênica no decorrer de toda a gestação (HILL et al., 1999, 2000, 2001; DE SOUSA et al., 2001; BERTOLINI et al., 2002a, 2004, 2006; CHAVATTE-PALMER et al., 2002; HASHIZUME et al., 2002; LEE et al., 2004; LI et al., 2005; ARNOLD et al., 2006; BATCHELDER et al., 2007a; FLETCHER et al., 2007; MIGLINO et al., 2007; PALMIERI et al., 2007; EVERTS et al., 2008; ZHOU et al., 2008). Neste estudo, alterações macroscópicas placentárias também foram encontradas, corroborando com os trabalhos anteriores. O grupo TNCS apresentou o dobro do peso total dos placentônios em comparação aos grupos FIV e Controle. Este aumento do peso dos placentônios já foi descrito por Chavatte-Palmer et al. (2002), Miglino et al. (2007) e Batchelder et al. (2007a) em placentas de clones bovinos ao nascimento. Da mesma forma, Bertolini et al. (2004) e Miles et al. (2004) também observaram aos 180 e 222 dias de gestação, respectivamente, placentas de animais FIV mais pesadas que as de controles produzidos in vivo. Os $6,2 \mathrm{~kg}$ de média do peso dos placentônios encontrados no corno 
gestante do grupo TNCS são muito próximos aos $6,0 \mathrm{~kg}$ encontrados por Batchelder et al. (2007a) em clones aos 280 dias.

Um reduzido número total de placentônios, no terço final da gestação, em placentas de clones já foi descrito por outros autores (HILL et al., 2001; CHAVATTE-PALMER et al., 2002; BATCHELDER et al., 2007a). Entretanto, neste experimento, a média de 72,6 placentônios do grupo TNCS não diferiu dos grupos Controle $(81,5)$ e FIV $(51,0)$, e foi muito semelhante às médias de 69,9 e 67,4 encontradas nos clones de Chavatte-Palmer et al. (2002) e Batchelder et al. (2007a), respectivamente. De maneira interessante, o grupo FIV neste experimento, apesar de não ter apresentado um menor número total de placentônios, apresentou um número significativamente menor no corno prenhe em comparação ao Controle (44,0 e 66,0, respectivamente), mas não muito diferente ao encontrado por Bertolini et al. (2002a) também no corno gestante de prenhezes FIV $(53,0 \pm 13,0)$. O número total de placentônios do grupo Controle permaneceu dentro da variação normal esperada de 70 a 120 para este tipo de gestação (MIGLINO, 1991).

O tecido placentário normalmente demonstra um alto grau de plasticidade frente a condições desfavoráveis, expressando mecanismos de adaptação a circunstâncias ambientais (FERRELL, 1989; KREBS; LONGO; LEISER, 1997; PENNINGA; LONGO, 1998) ou nutricionais (MCEVOY et al., 1997; PERRY et al., 1999) adversas, o que podem promover alterações morfo-histológicas na placenta. Hill et al. (1999), Bertolini et al. (2002a, 2004 e 2006) e Batchelder et al. (2007a) verificaram esta adaptabilidade com a hipótese de que em animais produzidos in vitro, especialmente em clones, uma redução no número de placentônios foi compensada com um aumento da massa (peso) e da área de superfície dos mesmos. Apesar de não ter ocorrido neste trabalho uma redução significativa no número de placentônios nos grupos in vitro (apenas uma redução numérica), a área de superfície da placenta do grupo TNCS foi maior que a dos grupos FIV e Controle. O aumento do peso e da área de superfície dos placentônios está correlacionado positivamente ao comprimento e largura dos mesmos. Bertolini et al. (2002a) verificaram um aumento significativo de placentônios com mais de $13 \mathrm{~cm}$ em placentas de animais FIV, relacionando o aumento da área de superfície da placenta à presença de placentônios gigantes com mais de $15 \mathrm{~cm}$ de comprimento. Da mesma forma, neste estudo, analisando-se apenas o corno prenhe, o grupo TNCS apresentou uma tendência $(P=0,060)$ da curva de freqüência do comprimento dos placentônios ser diferente do grupo Controle, com um desvio evidente para os de maior comprimento. De forma geral, o grupo TNCS apresentou os placentônios mais compridos, 
largos e pesados dentre os três grupos, com estas diferenças ficando mais evidentes no corno gestante.

A adaptação placentária além do peso e da área de superfície de contato pode promover mudanças no formato dos placentônios (BATCHELDER et al., 2007a). Estas alterações no formato podem influenciar na eficiência e capacidade de transporte de substratos ao feto e da função e metabolismo placentário (BERTOLINI; WALLACE; ANDERSON, 2006). Placentas de conceptos FIV apresentaram uma freqüência significativamente maior de placentônios "anormais" do tipo achatado (C) e semi-convexo (D) em relação às placentas de animais produzidos in vivo (BERTOLINI; WALLACE; ANDERSON, 2006). Neste trabalho, os grupos produzidos in vitro (FIV e TNCS) apresentaram uma freqüência semelhante em cada tipo de placentônio, sendo similares ao grupo Controle nos tipos com formato de cogumelo (B) e semi-convexo (D), e inferiores e superiores ao Controle nos tipos com formato de cogumelo engolfado (A) e achatado (C), respectivamente. Estas freqüências dos grupos Controle e TNCS foram muito semelhantes às freqüências apresentadas pelos mesmos grupos experimentais, dentro de cada tipo de placentônio, no experimento de Batchelder et al. (2007a). Naquele experimento inclusive, as mesmas diferenças entre os grupos também só se revelaram nos tipos " $\mathrm{A}$ " e " $\mathrm{C}$ ". Especulamos que a deficiência consiste na formação da placenta no início da gestação, quer seja por causas temporais, com o retardo de desenvolvimento do concepto, quer seja por falhas de reprogramação epigenética, que afetam a ativação e/ou inativação espacial e temporal de genes importantes para o desenvolvimento e que interferem no crescimento e estabelecimento da placenta, entre outras possibilidades. A coleta de material em um ponto específico da gestação (Dia 225), não nos permite inferir sobre a dinâmica deste processo, ou seja, se placentônios alteram a sua micro-arquitetura e morfologia, transformando-se de tipo A para B, B para C ou C para D ao longo da gestação. Porém, as evidências apontam esta diferença entre grupos como uma conseqüência de placentação deficiente, no terço inicial da prenhez, que se repercute em um comprometimento do desenvolvimento posterior destas estruturas, tornando-as alteradas morfologicamente. Análises distintas ainda devem ser realizadas com os espécimes coletados para elucidar esta questão.

A presença de fusões carunculares na placenta de bovinos já foi descrita em gestações in vivo, e considerada uma peculiaridade aceitável e dentro da normalidade da placenta de alguns indivíduos (BARRETO et al., 2009). Esta fusão parece ser promovida pelo crescimento exacerbado da margem dos placentônios, resultando na fusão de algumas carúnculas. Os três grupos apresentaram indivíduos com fusões carunculares, mas o grupo 
TNCS apresentou um aumento da freqüência e da intensidade destas fusões, que apareceram em cinco dos seis animais, com uma maior quantidade das mesmas, e com mais de dois placentônios presentes por fusão em algumas, corroborando com os achados de Barreto et al. (2009). Miglino et al. (2007) observaram este aumento de fusões em placentas de clones, com uma conseqüente redução no número de placentônios e do aparecimento de regiões na placenta com ausência completa de placentônios. Neste trabalho, estas grandes áreas ausentes de estruturas não foram observadas, talvez pela presença de microplacentônios $(<1 \mathrm{~cm})$ em todas as gestações do grupo TNCS, e de uma grande quantidade dos mesmos em duas das seis prenhezes.

Muitas das anormalidades descritas previamente em clones, incluindo edema das membranas fetais, hidropsias (hidroalantóide e hidroâmnio) dos anexos fetais, presença de placentônios gigantes, aumento do cordão umbilical e deformidades físicas dos fetos, também foram mostradas neste estudo. A presença de edema nas membranas da placenta de clones já foi amplamente citada (HILL et al., 1999; CHAVATTE-PALMER et al., 2002; LEE et al., 2004; LI et al., 2005; BATCHELDER et al., 2007a; MIGLINO et al., 2007) e apresenta-se como uma das mais freqüentes alterações encontradas em placentas de clones, o que corrobora com os nossos resultados, visto que os seis animais apresentavam este distúrbio. Em três destes animais, esta alteração apresentou-se tão intensificada, que as membranas adquiriram um aspecto gelatinoso (mixedema) dentro do útero, este grau de alteração já foi descrito por Miglino et al. em 2007, estando, segundo os autores, provavelmente associado a hidropsias dos anexos fetais. Interessantemente, apenas um dos quatro animais do grupo FIV apresentou edema das membranas, e com uma intensidade muito menor do que as apresentadas nos animais do grupo TNCS, enquanto que nenhuma alteração deste tipo foi observada no grupo Controle, o que nos permite especular, que o processo de produção in vitro e de transferência nuclear aumentaram a freqüência deste distúrbio, incrementando também a intensidade do mesmo.

Wintour, Laurence e Lingwood (1986) afirmaram que em casos de hidropsias das membranas fetais, uma grande mudança ocorre nos componentes destes fluidos. Entretanto, até o presente momento, as análises dos componentes dos fluidos fetais (eletrólitos, proteínas totais, etc.) não foram realizadas, com exceção da osmolalidade, impossibilitando a afirmação de que neste estudo, os animais do grupo TNCS apresentaram hidropsias. Contudo, o significativo aumento do peso do trato uterino gravídico em mais de duas vezes o peso médio apresentado pelos outros dois grupos, e a alta correlação com o volume total de fluidos $(\mathrm{R}=$ $0,908, \mathrm{P}<0,001)$, e o volume do fluido alantóide $(\mathrm{R}=0,841, \mathrm{P}=0,001)$, nos levam a 
especular que neste experimento, os clones apresentaram um quadro de hidropsias das membranas fetais. Ainda, dada a elevada correlação entre volume total de fluidos e o volume do alantóide $(\mathrm{R}=0,957, \mathrm{P}<0,001)$, e da relação de 5,1:1 de alantóide:âmnio, é possível indagar que estas hidropsias, se presentes, foram do tipo hidroalantóide. Esta afirmação pode ser feita para apenas quatro das seis prenhezes, já que em uma delas, os $21 \mathrm{~L}$ presentes no âmnio foram mais que o dobro do volume apresentado pelo alantóide, e três vezes maior que a média de volume do âmnio no grupo TNCS. Como o útero do Clone 1 se rompeu no momento da remoção deste órgão da cavidade abdominal, não se pode realizar qualquer suposição sobre este tipo de anormalidade neste animal, somente uma inferência clínica e uma estimativa não científica de que mais de $150 \mathrm{~L}$ estavam alocados naquele órgão antes da ruptura.

Bertolini et al. (2004) não observaram mudanças na composição dos fluidos em gestações FIV aos 180 dias de gestação. Porém, um volume duas a cinco vezes maior de alantóide foi observado em prenhezes FIV em relação a controles, concomitante a uma maior osmolalidade. Como estes pesquisadores encontraram uma maior concentração e quantidade de glicose e frutose nos fluidos fetais, e devido à natureza osmótica ativa destas moléculas, estes autores sugeriram que o efeito osmótico exercido por estes carboidratos pode ter causado um acúmulo de líquido e no aumento do volume total dos fluidos fetais, visto que uma correlação positiva foi encontrada entre volume, osmolalidade e concentração de açúcar nos fluidos. Entretanto, neste trabalho, esta correlação não foi observada, nem a diferença de osmolalidade em ambos os fluidos entre os grupos experimentais, apesar de um aumento numérico da osmolalidade ter sido encontrado no grupo TNCS. Li et al. (2005) não encontraram diferenças na osmolalidade dos fluidos fetais em gestações de controles, FIV e clones aos 150 dias, mas observaram uma grande variação na composição bioquímica destes fluidos. Estes estudos demonstram a grande variação existente entre prenhezes estabelecidas de embriões produzidos in vitro e in vivo, e da dificuldade de se estabelecer as reais alterações presentes neste tipo de gestação.

Próximo ao parto, entre 15 e 20 L de líquido são encontrados no útero, representando cerca de 20 a $25 \%$ do peso total do útero gravídico (SLOSS; DUFTY, 1980). Porcentagens muito similares foram encontradas nos grupos Controle (26,6\%) e FIV (26,4\%), mas aumentadas para o grupo TNCS (40,4\%), o que reforça ainda mais a possibilidade de hidropsias neste grupo. Apesar das amostras neste experimento terem sido coletadas aos 225 dias de gestação, os 7,8 e 9,7 L de fluidos totais dos grupos Controle e FIV, respectivamente, provavelmente tenderiam a alcançar os esperados 15-20 litros até o parto, visto que o aumento 
significativo de fluido acontece até os sete meses de gestação, com o acúmulo sendo linear e menor no terço final (ARTHUR, 1969), invertendo-se com o crescimento fetal, que apresenta $60 \%$ do seu crescimento neste período (FERRELL, 1989). A presença de hidropsias em gestações de animais produzidos in vitro já foi bem documentada na literatura (HASLER et al., 1995; CIBELLI et al., 1998; LI et al., 2005; CONSTANT et al., 2006; MIGLINO et al., 2007) e é considerada uma das principais causas de perdas gestacionais no terço final da gestação (EDWARDS et al., 2003).

O aumento do cordão umbilical associado ou não a edema já foi relatado em outros estudos (BATCHELDER et al., 2007a; MIGLINO et al., 2007; MEIRELLES et al., 2010) e está vinculado a uma persistência de úraco após o parto, e de infecções ascendentes decorrentes de flebites que podem acarretar na morte dos neonatos (EDWARDS et al., 2003). Neste trabalho, o aumento do diâmetro do cordão umbilical nos fetos do grupo TNCS foi avaliado visualmente, sendo mais ou menos evidente quando comparado aos cordões umbilicais dos fetos dos outros dois grupos. Ainda, não se realizou a análise histológica para averiguar a origem deste aumento, ou que estruturas estavam comprometidas e contribuíram para o desvio.

Deformidades físicas dos fetos são freqüentes em clones e não deixaram de estar presentes neste trabalho. A contratura dos tendões flexores de dois animais corrobora com os achados de Batchelder et al. (2007a) e apresenta causas indefinidas. Porém, estas contraturas podem ser decorrentes de um ou de mais fatores pré-natais associados, como o mau posicionamento intra-uterino, a hipoplasia óssea, ou a flacidez dos tendões, conforme discutido por aqueles autores.

Após a dissecação e análise macroscópica de todos os órgãos nos quatorze animais deste experimento, visualmente, apenas três animais do grupo TNCS apresentavam alguma anormalidade, sendo os três fetos com alterações hepáticas, e um (Clone 4) com alterações morfológicas renais. Hill et al. (1999), Chavatte-Palmer et al. (2002) e Heyman et al. (2002) relataram alterações de tamanho e presença de condições patológicas hepáticas em fetos e neonatos clones, estando associadas ou não a distúrbios em outros órgãos. Da mesma forma, anormalidades renais também foram observadas em estudos anteriores (KATO; TANI; TSUNODA, 2000; CHAVATTE-PALMER et al., 2002) e já foram associadas a condições de hidroalantóide por falhas na função renal de animais produzidos in vitro (VAN WAGTENDONK-de LEEUW et al., 1998; LI et al., 2005). Entretanto, Lee et al. (2004) discutindo a presença de hidropsias em gestações de clones, associaram a organomegalia envolvendo o fígado, rins e coração ao aumento da incidência de hidrâmnio. Como a 
homeostasia dos fluidos do compartimento fetal ainda não está completamente compreendida, e a etiologia e patogênese das hidropsias das membranas fetais carece de melhores explicações (SLOSS; DUFTY, 1980), torna-se difícil definir ou sugerir as razões que levem ao aumento da freqüência e gravidade deste distúrbio gestacional em animais produzidos in vitro (EDWARDS et al., 2003). Todavia, não restam dúvidas de que o aumento de alterações, em gestações produzidas in vitro, na placenta e em órgãos fetais, como os rins, esteja diretamente associado ao aumento das hidropsias das membranas fetais, sejam do âmnio ou do alantóide.

Após as análises de comprimento e peso de praticamente todos os órgãos e tecidos dos fetos coletados aos 225 dias, os animais do grupo TNCS apresentaram um aumento significativo nestas mensurações em muitas das características analisadas. Porém, após o ajuste estatístico pela comparação por análise de covariância, com o peso fetal utilizado como co-variável, estas diferenças em sua grande maioria desapareceram. Esta observação também foi realizada por Bertolini et al. (2004) em animais FIV aos 180 dias de gestação, onde algumas diferenças também desapareceram quando o mesmo ajuste foi conduzido, demonstrando que tanto neste quanto naquele experimento, as medidas e pesos dos grupos in vitro foram maiores em valores absolutos, pois o tamanho dos fetos nestes grupos também foi maior, ocorrendo um crescimento alométrico dos órgãos e tecidos, que em geral acompanharam a proporção do tamanho fetal. As reais diferenças existentes entre os grupos neste experimento ficaram restritas ao timo torácico que foi menor para ambos os grupos in vitro, e para o comprimento da traquéia e o peso do baço que foram cerca de duas vezes menores para o grupo TNCS em comparação aos grupos Controle e FIV. O significado clínico e fisiológico destes achados é obscuro, mas sabe-se que após o nascimento, resultados conflitantes sobre a normalidade do sistema imune já foram publicados (CHAVATTEPALMER et al., 2009). No período neonatal, relatos de clones com atrofia de timo e redução do baço foram apresentados por outros pesquisadores (RENARD et al., 1999; KUBO, 2002), e estão associados a um aumento na incidência de infecções de animais jovens (CHAVATTEPALMER et al., 2004), sendo uma das possíveis causas para uma redução na contagem de células vermelhas e brancas do sangue ao nascimento (BATCHELDER et al., 2007b). Em adição, Meirelles et al. (2010) relataram um quadro clínico de acidose respiratória (com baixa concentração arterial de oxigênio) associada a uma estenose do terço distal da traquéia de um neonato clone, que foi confirmada no exame post-mortem, onde se observou uma redução significativa do diâmetro distal do órgão. Neste trabalho, esta redução no diâmetro não foi 
mensurada, mas a redução do comprimento da traquéia do grupo TNCS foi significativa (após o ajuste por covariância) em relação aos outros grupos.

De forma muito interessante, a gestação conduzida a termo e que gerou um produto clonado nascido em 2008 (Capítulo 4) apresentou um quadro clínico com alterações que podem ser comparadas ou associadas às anormalidades encontradas nos seis fetos do grupo TNCS. O nascimento foi por cesariana eletiva aos 289 dias, sendo uma fêmea com $39 \mathrm{~kg}$ que apresentou alguns parâmetros físico-clínicos associados ao alto risco de vida neonatal, incluindo tingimento por mecônio, cordão umbilical aumentado, dificuldade respiratória e tempo elevado para ingerir colostro e permanecer em estação ( $>3$ h). Estas características são descritas como freqüentes em clones (BATCHELDER et al., 2007a) e vinculadas a elevadas taxas de mortalidade nas primeiras semanas de vida. Aproveitando-se o acesso à cavidade uterina, três placentônios foram excisados do útero após a remoção do produto, com um destes apresentando mais de $22 \mathrm{~cm}$ de comprimento e pesando mais de $1 \mathrm{~kg}$. Entre várias terapias clínicas e medidas profiláticas de auxílio na manutenção da homeostasia, como transfusões isólogas (da fêmea doadora das células) de sangue e adequação do ambiente, o animal nascido permaneceu as primeiras duas semanas em oxigenioterapia, visando o suprimento contínuo de oxigênio, visto que a pressão parcial arterial de oxigênio só pode ser estabilizada e mantida naturalmente após este período. Apesar do aumento do cordão umbilical, este animal não apresentou persistência de úraco, mas optou-se pela remoção cirúrgica do coto umbilical um mês após o nascimento, já que o tamanho do tecido não reduziu espontaneamente. Mesmo com todos estes distúrbios e dificuldades encontradas em manter o animal vivo e saudável, esta fêmea atualmente se encontra com 18 meses, e pesando mais de $500 \mathrm{~kg}$.

O excessivo padrão de crescimento fetal observado no final da gestação de embriões PIV parece estar associado a um aumento no aporte de substratos energéticos aos tecidos útero-placetário-fetais, em especial a glicose (BERTOLINI et al., 2004). As concentrações de glicose não diferiram entre os três grupos deste experimento e mantiveram uma concentração nos plasmas fetais de $20-30 \%$ dos níveis maternos, porcentagens muito similares às encontradas por Reynolds et al. (1990) e Bertolini et al. (2004). Em contrapartida, e conforme o esperado, as concentrações de frutose no plasma materno mostraram-se irrisórias quando comparadas aos valores nos plasmas e fluidos fetais, em especial no alantóide. A frutose é sintetizada pela placenta a partir da glicose, sendo o principal carboidrato no plasma e fluidos fetais, uma particularidade de espécies com placentas sinepitélio- ou epitélio-coriais, como os ungulados e cetáceos (GOODWIN, 1956; NIXON, 1963). Aldoretta e Hay (1999) verificaram 
em ovinos, que a taxa de produção de frutose parece depender diretamente do suprimento de glicose à placenta.

Como o fluido amniótico é composto predominantemente por líquidos transmurais e também oriundos da cavidade oro-nasal, urina fetal e da transpiração do feto, e o alantóide predominantemente por via transmural e pela urina fetal até o final da gestação (SLOSS; DUFTY, 1980), a quantidade de carboidratos presentes em ambos os compartimentos é fruto da quantidade presente no sistema fetal. Considerando os seguintes achados nas quantidades de carboidratos nos compartimentos fetais: (a) a quantidade total de glicose foi cerca de dez e sete vezes maior no alantóide e em ambos os fluidos, respectivamente, no grupo TNCS em relação aos demais; (b) a quantidade total de frutose no grupo TNCS foi significativamente maior ao Controle no alantóide; e (c) a quantidade total de ambos os carboidratos no alantóide foi maior para o TNCS em relação ao Controle, e tendeu a ser maior em ambos os compartimentos (âmnio + alantóide). Estes resultados, associados ao fato de que a placenta apresentou um maior peso e área de superfície no grupo TNCS, demonstram uma maior utilização ou aporte de glicose e frutose ao feto, favorecendo o crescimento fetal no terço final da gestação e explicando o maior tamanho encontrado nos conceptos dos grupos produzidos in vitro deste experimento, em especial, do grupo TNCS.

Os grupos Controle, FIV e TNCS não diferiram para a diferença de concentração de glicose entre a veia e artéria fetal, conforme demonstrado na figura 6.10. Entretanto, para a diferença de concentração de frutose, os grupos TNCS e FIV apresentaram médias próximas de zero, sendo menores que o Controle. Como as concentrações de frutose não diferiram nestes fluidos entre os grupos experimentais, isto parece indicar não ter havido utilização fetal de frutose de origem placentária, ou retorno fetal de frutose (anabolismo e catabolismo em equilíbrio). Isto se contrapõe ao observado nos animais controle, que demonstraram uma diferença venosa-arterial média próxima de $20 \mathrm{mg} / \mathrm{dL}$. Meznarich et al. (1987) demonstraram em ovinos, que a produção de frutose pela placenta é igual ao consumo do feto, e associaram as rápidas taxas de troca de frutose entre a placenta e o feto a um papel duplo da placenta, como produtora e consumidora desta frutose no sangue fetal. A diferença de concentração positiva de frutose no grupo Controle, neste trabalho, é difícil de ser explicada, já que não possuímos o fluxo sanguíneo e dos carboidratos deste sistema. Algumas hipóteses podem ser formuladas: (a) uma baixa sensibilidade do método analítico possa ter promovido esta diferença entre os grupos; (b) uma saturação de frutose do sistema, particularmente no grupo TNCS, conforme evidenciado pela quantidade deste carboidrato nos fluidos fetais possa ter elevado as concentrações na artéria fetal, anulando a diferença de concentração neste grupo; 
(c) o consumo de frutose pela placenta no grupo Controle não seria tão intenso como na placenta das gestações in vitro, o que disponibilizaria uma maior quantidade deste carboidrato ao feto, enquanto que a placenta dos grupos in vitro, talvez pela maior massa e área de superfície, utilize uma maior quantidade de frutose, igualando as concentrações entre os vasos sanguíneos.

Os resultados deste trabalho demonstraram que distintas diferenças ocorreram entre os grupos Controle, FIV e TNCS, independente do momento gestacional analisado, com o último apresentando as maiores alterações e desvios dentre os três, e dentre a normalidade esperada para a espécie e raça. De forma geral, este experimento demonstrou que as diferenças entre os grupos experimentais ocorreram desde as análises iniciais, com os grupos in vitro apresentando menores taxas de prenhez, e com o grupo TNCS tendo as maiores perdas gestacionais. As imagens obtidas por ultrasonografia aos 51 dias revelaram conceptos in vitro retardados em seu desenvolvimento, mas com um crescimento compensatório posterior, já que as prenhezes produzidas in vitro, e especialmente as do grupo TNCS, sustentaram não só maiores conceptos e com maiores anormalidades aos 225 dias de gestação, como também apresentaram um maior acúmulo de substratos energéticos no sistema fetal, particularmente de frutose no alantóide. O grupo FIV em muitos aspectos apresentou valores e taxas similares ao Controle, mas em outros, comportou-se como um meio termo entre os dois outros grupos, com distúrbios inerentes ao processo de produção in vitro per se, porém, com anormalidades não tão agravadas como as que ocorreram no grupo TNCS, que além dos processos de produção in vitro, passou pelo processo da transferência nuclear, evento já associado à intensificação das alterações no desenvolvimento posterior.

Mais trabalhos envolvendo o estudo da morfofisiologia, metabolismo, reprogramação epigenética e controle da expressão gênica devem ser conduzidos com conceptos produzidos in vitro, propiciando uma maior e melhor compreensão dos eventos envolvidos com as anormalidades descritas na fase final da gestação, permitindo também identificar os componentes ou fatores causais presentes no desenvolvimento embrionário inicial que determinam as alterações fenotípicas observadas posteriormente no desenvolvimento, inclusive na fase pós-natal. 
CAPÍtUlO 4 ANÁLISE RETROSPECTIVA DA EVOLUÇÃo TÉCNICA E EFICIÊNCIA DO PROCESSO DE CLONAGEM POR HANDMADE CLONING EM BOVINOS ${ }^{4}$

\footnotetext{
${ }^{4}$ Artigo a ser submetido para a revista Reproduction in Domestic Animals
} 


\section{INTRODUÇÃO}

Desde o nascimento da ovelha Dolly (WILMUT et al., 1997), primeiro mamífero produzido a partir da transferência nuclear de células somáticas (TNCS), a variedade de espécies animais clonadas expandiu-se significativamente (BERTOLINI et al., 2007), com as mais recentes sendo o dromedário (Camelus dromedarius - publicado na mídia) e o búfalo (Bubalus bubalis - publicado na mídia) em 2009. Estes animais, em sua grande maioria, têm sido produzidos pelo procedimento tradicional ou clássico, o qual necessita de equipamentos de elevado custo, particularmente micromanipuladores (VAJTA et al., 2003), operados por técnicos qualificados altamente treinados. Tais características limitam tecnicamente a realização do procedimento por mais de um operador, restringindo o número de embriões produzidos por procedimento, o que determinou uma difusão mais restrita da TNCS nos anos que sucederam a Dolly (VAJTA et al., 2003). Por conseguinte, o avanço do conhecimento também sofreu atrasos por razão de tais restrições.

A produção de embriões clones bovinos pela metodologia do "Handmade Cloning" (HMC), ou clonagem manual, proposta como estratégia científica por Peura, Lewis e Trounson (1998) com células embrionárias (blastômeros), e efetivada com sucesso para uso amplo com células somáticas por Vajta et al. (2001), dispensa por completo o uso de micromanipuladores. A associação do HMC ao sistema de cultivo em micro-poços, ou Wellof-the-Well (WOW), desenvolvido pelo mesmo grupo de pesquisadores (VAJTA et al., 2000), colaborou na viabilização da execução da clonagem por TNCS em larga escala, aumentando a capacidade de produção de embriões clones e a eficiência geral da técnica, reduzindo o tempo de execução e elevando a padronização dos resultados obtidos (VAJTA et al., 2003; VAJTA; ZHANG; MACHÁTY, 2007). Pela simplicidade, praticidade e baixo custo, a metodologia do HMC universalizou a clonagem animal, permitindo que muitos laboratórios de embriologia no mundo pudessem aplicá-la, o que promete acelerar o avanço científico. Ainda, a ausência da zona pelúcida associada ao sistema WOW proporcionou uma excelente ferramenta para estudo de fundamentos básicos e aplicados da embriologia em espécies mamíferas, como de efeitos da variação do volume citoplasmático (PEURA; LEWIS; TROUNSON, 1998), da agregação embrionária (BOIANI et al., 2003; MISICA-TURNER et al., 2007; RIBEIRO et al., 2009), da alocação celular (MISICA-TURNER et al., 2007) ou mesmo da fusão de distintos citoplastos e carioplastos (MEZZALIRA, 2009) em embriões clones. 
No Brasil, distintos laboratórios de pesquisa e empresas comerciais já produziram clones bovinos de diferentes raças utilizando a metodologia clássica com o emprego de micromanipuladores (revisado em BERTOLINI et al., 2007), mas não há relatos científicos de produção de produtos nascidos utilizando a metodologia de baixo custo do HMC, com a comprovação nacional de sua versatilidade científica. Ainda, não existe na literatura uma descrição da evolução de uma técnica como a da clonagem por HMC em um único laboratório, e que apresente os dados de um longo período e com um número significativo de estruturas utilizadas. Desta forma, os objetivos deste trabalho, foram (a) comparar a evolução temporal dos resultados da clonagem por HMC obtidos em nosso laboratório em três períodos distintos de atividades a partir da implementação da metodologia, e (b) determinar os efeitos do aumento da experiência técnica sobre as taxas de produção de embriões e estabelecimento de prenhezes ao longo do tempo, demonstrado, em seu final, pelo nascimento de bovino viável a termo no Brasil produzido pela clonagem manual e agregação embrionária. Pela descrição detalhada da metodologia modificada utilizada em nosso laboratório, também almejamos a disseminação desta técnica, compartilhando o seu uso com grupos de pesquisa que desejam implementar a clonagem manual em seus laboratórios.

\subsection{MATERIAL E MÉTODOS}

Todos os reagentes utilizados foram provenientes da Sigma-Aldrich Chemical Co. (St. Louis, MO, EUA), salvos os que são indicados à parte.

\subsubsection{Delineamento Experimental}

Os resultados de produção in vitro de embriões por TNCS/HMC e desenvolvimento in vivo subsequente obtidos em três períodos de sete meses de rotinas experimentais, dentro de um período total de 28 meses, foram compilados em: Período 1 (P1), de janeiro a agosto de 2007; Período 2 (P2), de dezembro de 2007 a julho de 2008; e Período 3 (P3), de outubro de 2008 a maio de 2009. 


\subsubsection{Cultivo Celular de Células Somáticas}

Células somáticas de origem cutânea provenientes de uma fêmea bovina da raça Nelore foram obtidas por explantação seguindo os procedimentos descritos por Gerger et al. (2010). Brevemente, uma biópsia auricular foi coletada de forma asséptica, imersa sequencialmente por $20 \mathrm{~s}$ em álcool $70^{\circ} \mathrm{GL}$ e solução de antibiótico-antimicótico a $100 \mathrm{x}$, lavada abundantemente em meio de cultivo, seccionada em fragmentos de 3 a $4 \mathrm{~mm}$ e dispostos em placas de cultivo celular de $35 \mathrm{~mm}$ (Corning Incorporated, NY, EUA), em número de 4 a 5 fragmentos por placa, em $0,8 \mathrm{~mL}$ de meio de cultivo (DMEM - Dulbecco's modified Eagle's Medium, Gibco-BRL, NY, EUA) acrescido de 0,22 $\mathrm{mM}$ de piruvato de sódio, 26,2 mM de $\mathrm{NaHCO}_{3}, 100 \mathrm{UI} / \mathrm{mL}$ de penicilina $\mathrm{G}, 100 \mu \mathrm{g} / \mathrm{mL}$ de sulfato de estreptomicina, $0,25 \mu \mathrm{g} / \mathrm{mL}$ de anfotericina B e $10 \%$ de soro fetal bovino (SFB, Gibco-BRL). Os cultivos foram estabelecidos, mantidos e expandidos em incubadora a $38,5^{\circ} \mathrm{C}$, com atmosfera controlada de $5 \%$ de $\mathrm{CO}_{2}$ e umidade saturada.

Partidas de células foram congeladas até no máximo a terceira passagem para uso na clonagem manual. Brevemente, quando os cultivos celulares atingiram confluência maior que $90 \%$, as células foram suspensas em uma solução de tripsina a 0,25\% e 0,5 mM de EDTA por 5 a 7 min e centrifugadas a $4000 \mathrm{~g}$ por $3 \mathrm{~min}$. A seguir, as células foram re-suspensas em meio de cultivo com $10 \%$ de dimetil sulfóxido (DMSO) e envasadas assepticamente em palhetas estéreis de $0,25 \mathrm{~mL}$ em volume aproximado de $150 \mu \mathrm{L}$, para uma concentração de 1 x $10^{3}$ células $/ \mu \mathrm{L}$. As palhetas foram mantidas entre 2 a $4^{\circ} \mathrm{C}$ por 15 min e então expostas ao vapor de nitrogênio líquido $\left(\mathrm{N}_{2} \mathrm{~L}\right)$ a uma temperatura entre -80 a $-110^{\circ} \mathrm{C}$ por $5 \mathrm{~min}$, sendo imersas em $\mathrm{N}_{2} \mathrm{~L}$ e estocadas para uso posterior. O descongelamento foi realizado $72 \mathrm{~h}$ antes da utilização na rotina de clonagem por $\mathrm{HMC}$, por imersão em água a $36^{\circ} \mathrm{C}$ por $30 \mathrm{~s}$, seguido do cultivo em placas de cultivo celular de 4-poços (Nunclon ${ }^{\circledR} 144444$ - Nunc, Roskilde, Dinamarca), pela diluição direta do volume de cada palheta em $500 \mu \mathrm{L}$ de meio de cultivo/poço, visando obter uma confluência elevada ( $>95 \%) 24 \mathrm{~h}$ antes de sua utilização (GERGER et al., 2010). Aproximadamente 6 h após a semeadura das células descongeladas, realizava-se a troca do meio de cultivo para a remoção de células mortas e de remanescentes do meio de congelação. 


\subsubsection{Produção In Vitro de Embriões por Transferência Nuclear de Célula Somática e por Partenogênese}

A produção in vitro de embriões por TNCS foi estabelecida utilizando a metodologia do Handmade Cloning (HMC), desenvolvida por Vajta et al. (2003) e adaptada às condições de nosso laboratório (RIBEIRO et al., 2009; GERGER et al., 2010), conforme abaixo. Os procedimentos de maturação e cultivo in vitro foram realizados em placas de cultivo celular de 4-poços.

Maturação in vitro (MIV) - Os Complexos cumulus-oócito (CCOs) aspirados de ovários bovinos coletados de três frigoríficos regionais foram morfologicamente selecionados em Graus 1, 2 e 3 segundo a classificação de Gonçalves, Figueiredo e Freitas (2008) e submetidos à MIV por 17 h, em meio M199 composto por TCM-199 (M2520), suplementado com 26,2 mM de $\mathrm{NaHCO}_{3}, 0,2 \mathrm{mM}$ de piruvato de sódio, $0,5 \mu \mathrm{g} / \mathrm{mL}$ de FSH (Folltropin ${ }^{\circledR}-\mathrm{V}$, Bioniche Animal Health Inc., Canadá), $5 \mu \mathrm{g} / \mathrm{mL}$ de LH (Lutropin ${ }^{\circledR}-\mathrm{V}$, Bioniche Animal Health Inc., Canadá) e 10\% de Soro de Égua em Estro inativado (SEE), em incubadora a $38,5^{\circ} \mathrm{C}, 5 \%$ de $\mathrm{CO}_{2}$ e umidade saturada.

Transferência nuclear de células somáticas (TNCS) - As células do cumulus oophorus e da corona radiata foram removidas dos CCOs por pipetagem contínua em M199H composto por TCM-199 (M2520), suplementado com 2,4 mM de $\mathrm{NaHCO}_{3}, 2,0 \mathrm{mM}$ de piruvato de sódio e $10 \%$ de SFB. Em seguida, os oócitos maturados foram selecionados pela presença do $1^{\circ}$ corpúsculo polar, sob lupa estereomicroscópica. Destes, removeu-se a zona pelúcida (ZP) pela breve exposição a uma solução de protease (P-8811) a 0,5\% em M199H + 0,01\% de álcool polivinílico (PVA), conforme ilustrado na figura 7.1. Em seguida, os oócitos sem $\mathrm{ZP}$ foram incubados por $10 \mathrm{~min}$ em $5 \mu \mathrm{g} / \mathrm{mL}$ de citocalasina B (CCB, C-6762) em $\mathrm{M} 199 \mathrm{H}+10 \% \mathrm{SFB}$, e submetidos à bisecção manual, em grupos de 2 a 3 oócitos por

microgotas de $5 \mu \mathrm{L}$, sob óleo mineral, utilizando-se uma lâmina de bisecção (Ultra-sharp Splitting Blade, Bioniche Inc., EUA), sob lupa estereomicroscópica (Figura 7.1). Após a bisecção, e seguindo-se a incubação em $10 \mu \mathrm{g} / \mathrm{mL}$ de bisbenzimida (Hoechst 33342, B-2261) em $\mathrm{M} 199 \mathrm{H}+\mathrm{SFB}$ por $10 \mathrm{~min}$, os hemi-oócitos contendo aproximadamente $50 \%$ do volume citoplasmático original foram selecionados em um microscópio invertido de epifluorescência (XDY-1, China) com filtro UV em enucleados e nucleados (Figura 7.1), conforme a presença da placa metafásica. Os hemi-oócitos enucleados (hemi-citoplastos) foram lavados em M199H + 10\% SFB para uso na reconstrução embrionária. 
As células doadoras de núcleo foram obtidas após a tripsinização de cultivos celulares em alta confluência (>95\%), sendo utilizadas para a reconstrução apenas células individualizadas de pequeno tamanho, arredondadas e com a membrana celular intacta, visando o aumento na proporção de células na fase G0/G1 do ciclo celular (BOQUEST; DAY; PRATHER, 1999). A reconstrução das estruturas embrionárias clonadas ocorreu mediante a breve exposição de hemi-citoplastos a $500 \mu \mathrm{g} / \mathrm{mL}$ de fitohemaglutinina (PHA, L8754) em M199H + 0,01\% PVA, seguida da adesão de uma célula somática, localizada em uma microgota contendo uma pequena fração da suspensão de células. Para a formação de hemi-embriões (embriões com 50\% do volume citoplasmático final, produzidos nos períodos P1 e P2), apenas um hemi-citoplasto foi aderido a uma célula doadora, enquanto que para a produção de embriões com $100 \%$ do volume citoplasmático final (embriões em todos os períodos), utilizaram-se dois hemi-citoplastos dispostos linearmente com a célula somática em uma das extremidades (Figura 7.1). As estruturas reconstruídas foram lavadas em M199H + $10 \%$ SFB e em seguida em meio de eletrofusão (EF) contendo 0,3 $\mathrm{M}$ de manitol, 0,05 mM de $\mathrm{CaCl}_{2} \cdot 2 \mathrm{H}_{2} \mathrm{O}, 0,1 \mathrm{mM}$ de $\mathrm{MgSO}_{4} \cdot 7 \mathrm{H}_{2} \mathrm{O}, 0,5 \mathrm{mM}$ de Hepes e $0,01 \%$ de PVA, para então serem distribuídas em uma câmara de fusão de 3,2 mm de espaço entre eletrodos (BTX 453, BTX Instruments, Genetronics, CA, EUA) contendo $650 \mu \mathrm{l}$ de meio EF, acoplada a um aparelho de eletrofusão (Voltain ${ }^{\mathrm{TM}}$ EP-1 Cell Fusion System, Cryologic, Austrália, somente no período P1, e BTX Electro Cell Manipulator 200, Biotechnologies \& Experimental Research Inc., San Diego, CA, EUA nos períodos P2 e P3). As estruturas reconstruídas foram submetidas a um pré-pulso de corrente alternada (AC) de $15 \mathrm{~V}$ por $5 \mathrm{~s}$ para a indução do alinhamento, seguido de dois pulsos elétricos de corrente contínua (DC) de $1,25 \mathrm{kV} / \mathrm{cm}$ por $20 \mu$ s para a fusão das membranas celulares (Figura 7.1). As estruturas submetidas à fusão foram cultivadas individualmente, em microgotas de $5 \mu \mathrm{L}$ sob óleo, por 45 a 60 min em M199 + 10\% SFB, em incubadora a $38,5^{\circ} \mathrm{C}, 5 \%$ de $\mathrm{CO}_{2}$ e umidade saturada, para a avaliação da taxa de fusão. Os hemi-embriões e embriões fusionados e grupos de oócitos com ZP intacta (grupo controle por partenogênese) foram quimicamente ativados em $5 \mu \mathrm{M}$ de ionomicina (I-0634) em M199H + $10 \%$ SFB por 5 min, seguido da incubação individualizada em microgotas de $5 \mu \mathrm{L}$ de M199+ 10\% SFB contendo $2 \mathrm{mM}$ de 6-dimetilaminopurina (6-DMAP, D-2629), sob óleo mineral, durante $4 \mathrm{~h}$. Em algumas rotinas dos períodos P1 e P2, os hemi-embriões e embriões que não fusionaram e permaneceram viáveis foram submetidos a uma segunda fusão (re-fusão) minutos após o término da primeira avaliação, sob as mesmas condições anteriores, para serem então cultivadas até a ativação em conjunto com as demais estruturas. O intervalo 
fusão-ativação, portanto, foi de aproximadamente $2 \mathrm{~h}$ (25 h após o começo da maturação) para embriões e hemi-embriões fundidos, e menor do que $1 \mathrm{~h}$ para embriões re-fundidos.

Cultivo in vitro (CIV) e formação dos grupos experimentais - Os hemi-embriões $(50 \%)$ e embriões $(100 \%)$ clonados foram cultivados em micro-poços pelo sistema Well-ofthe-Well (WOW), de acordo com Vajta et al. (2000), e modificado por Feltrin et al. (2006). Os micro-poços foram confeccionados manualmente dentro de poços de placas 4-poços (Figura 7.1) contendo $400 \mu \mathrm{L}$ de meio SOFaaci (HOLM et al., 1999) suplementado com 0,34 mM de citrato tri-sódico, 2,77 $\mathrm{mM}$ de mio-inositol, $30 \mu \mathrm{L} / \mathrm{mL}$ de aminoácidos essenciais (BME B6766) e $10 \mu \mathrm{L} / \mathrm{mL}$ de aminoácidos não-essenciais (MEM - M7145), acrescido de 5\% de SEE e $10 \mu \mathrm{L} / \mathrm{mL}$ de uma solução contendo $5 \mu \mathrm{g} / \mathrm{mL}$ de insulina, $5 \mu \mathrm{g} / \mathrm{mL}$ de transferrina e 5 ng/mL de selenito de sódio (ITS-X, I-1884), sob óleo mineral. Os embriões e hemi-embriões foram alocados nos micro-poços em duas disposições: G1 (2 x 50\%), grupo formado pela agregação de dois hemi-embriões em um único micro-poço resultando em um volume citoplasmático final aproximado de 100\%, obtido por agregação (períodos P1 e P2); e G2 (1 x 100\%), grupo formado pela alocação individual de um único embrião dentro de um micropoço, resultando também em um volume citoplasmático final aproximado de $100 \%$ (todos os períodos P1, P2 e P3). Os embriões controle (G3, partenotos, 1 x 100\%), composto por grupos de oócitos ativados com ZP intacta, utilizados para comprovar a viabilidade citoplasmática dos oócitos em cada rotina, foram cultivados em poços sem micro-poços, sob as mesmas condições acima (todos os períodos P1, P2 e P3). As placas de CIV foram incubadas utilizando o sistema Foil Bag (VAJTA et al., 1997), com atmosfera de 5\% $\mathrm{CO}_{2}, 5 \% \mathrm{O}_{2}$ e $90 \%$ $\mathrm{N}_{2}$, a $39^{\circ} \mathrm{C}$ por sete dias. No Dia 2 de CIV (48 h de desenvolvimento embrionário; início da ativação $=$ hora 0$)$, realizou-se a avaliação da clivagem embrionária. No Dia $7(168$ h) de CIV, avaliou-se a taxa de desenvolvimento embrionário (Figura 7.1) levando-se em consideração o estádio de desenvolvimento e a qualidade embrionária dos blastocistos produzidos, de acordo com Stringfellow e Seidel (1998). 


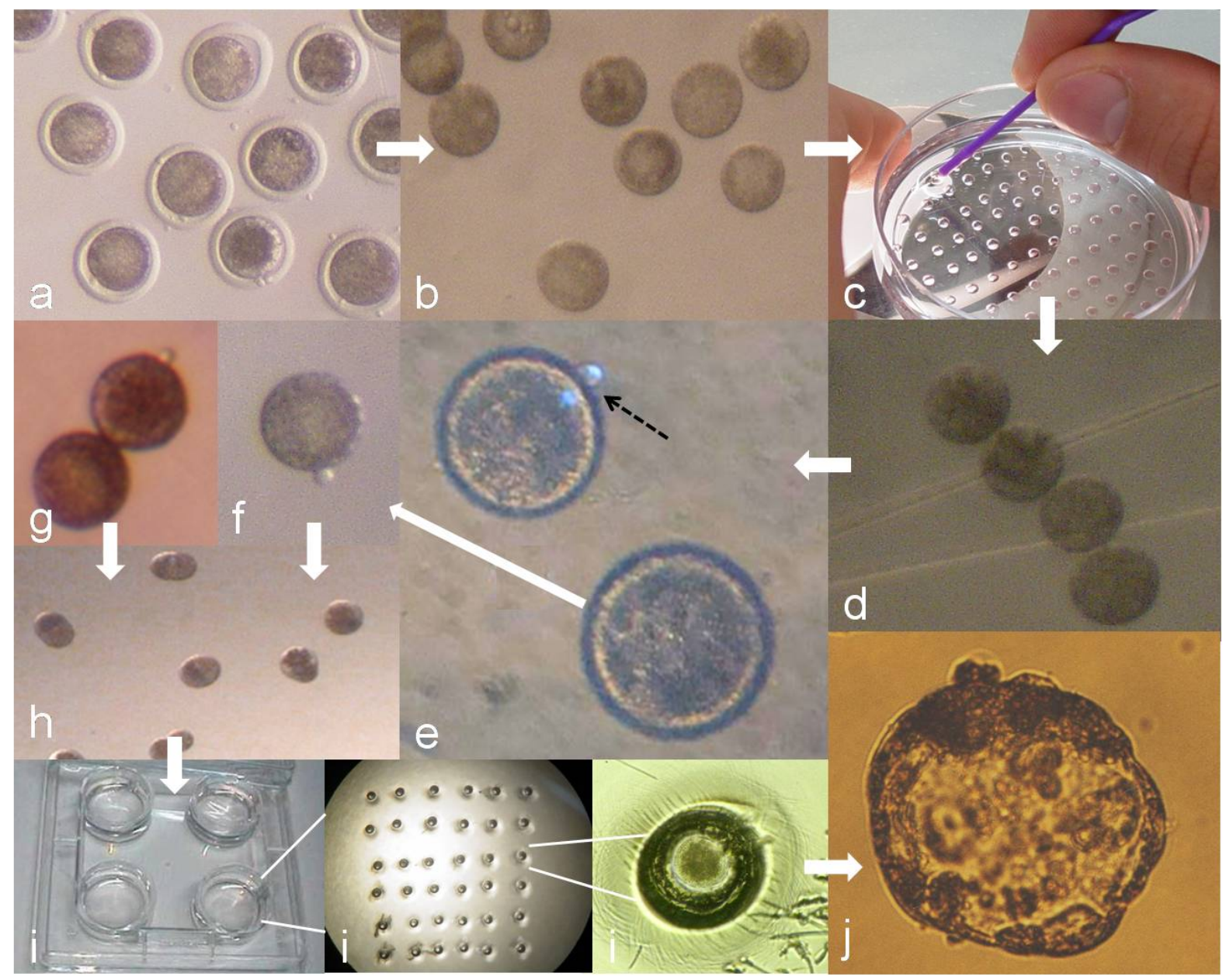

Legenda: (a) oócitos em metáfase II com zona pelúcida; (b) oócitos em metáfase II sem zona pelúcida; (c) bisecção manual dos oócitos; (d) oócitos seccionados aproximadamente na metade (hemioócito) com $50 \%$ do volume inicial em cada metade resultante; (e) dois hemi-oócitos, um enucleado e o outro com a presença da placa metafásica e do $1^{\circ}$ corpúsculo polar (seta tracejada); (f) reconstrução de hemi-embrião ( $50 \%$ do volume citoplasmático) com um hemioócito e uma célula; $(\mathrm{g})$ reconstrução de embrião (100\% do volume citoplasmático) com dois hemi-oócitos e uma célula; (h) fusão das membranas após estímulo elétrico; (i) confecção dos WOWs dentro de cada poço e alocação dos hemi-embriões agregados $(2 \times 50 \%)$ e embriões (1 x 100\%); (j) blastocisto produzido no dia 7 do cultivo in vitro

Figura 7.1 - Ilustração das principais etapas do procedimento de clonagem por transferência nuclear de célula somática utilizando a técnica do Handmade Cloning

\subsubsection{Viabilidade In Vivo}

Buscando-se avaliar o potencial de viabilidade in vivo, grupos de blastocistos clonados de ambos os tipos de embriões reconstruídos (G1, 2 × 50\% e/ou G2, 1 x 100\%) foram transferidos para fêmeas receptoras (1 ou 2 por fêmea) síncronas no dia 7 do ciclo estral, seguindo os procedimentos preconizados por Stringfellow e Seidel (1998). Os embriões dos períodos P1 e P2 (G1, 2 x 50\% e G2, 1 x 100\%) foram transferidos para receptoras em uma 
central de receptoras distante $4 \mathrm{~h}$ do laboratório (Central Santa Rita de Embriões Ltda., Itajaí, $\mathrm{SC}$ ), enquanto que os embriões do período P3 (somente G2, 1 x 100\%) foram transferidos para receptoras em uma estação experimental (EPAGRI, Lages, SC) distante $10 \mathrm{~min}$ do laboratório, ambos por transporte rodoviário. O transporte dos embriões ocorreu em M199H + $20 \% \mathrm{SFB}$, após o envase em palhetas de $0,25 \mathrm{~mL}$, mantidas a uma temperatura média de $37^{\circ} \mathrm{C}$ até a transferência por via cervical. Os diagnósticos de gestação foram realizados aos 28-30 dias de gestação por ultrasonografia transretal, utilizando um aparelho de ultrasonografia veterinário portátil em tempo real (Aloka ${ }^{\mathrm{TM}}$ SSD-500V ou 100 Falco $^{\circledR}$ - Pie Medical) equipado com um transdutor linear de $5 \mathrm{MHz}$. O diagnóstico do gênero fetal (sexagem) foi realizado aos 58 dias, e a viabilidade e presença ou não de anormalidades nos conceptos durante as prenhezes foi acessada semanalmente dos 30 aos 100 dias de prenhez. A partir de então, as prenhezes foram monitoradas por palpação retal com intervalos de duas semanas, com uso de procedimento ultrasonográfico ocasional.

\subsubsection{Análise Estatística}

Os dados foram analisados utilizando o programa estatístico Minitab (PA, USA). As taxas de fusão e re-fusão, clivagem, blastocisto e de prenhez, assim como as freqüências da qualidade embrionária (Grau 1, ótimo; Grau 2, bom; Grau 3, ruim) e do estádio de desenvolvimento (Estádio 5, blastocisto inicial; Estádio 6, blastocisto; Estádio 7, blastocisto expandido; Estádios 8/9, blastocistos em eclosão ou eclodidos) no Dia 7, foram comparadas pelo teste do $\chi^{2}$, para $\mathrm{p}<5 \%$.

\subsection{RESULTADOS}

Um total de 21.231 CCOs foi colocado em maturação in vitro no período total de 28 meses de execução destes experimentos, com 5.432, 10.721 e 5.078 CCOs sendo utilizados em 16, 18 e 10 rotinas nos períodos P1, P2 e P3, respectivamente. A taxa de maturação, baseada na presença do $1^{\circ}$ corpúsculo polar após a MIV, foi de 65,2\% (3.544/5.432), 63,9\% $(6.855 / 10.721)$ e $54,5 \%(2.766 / 5.078)$, para os três períodos, respectivamente, havendo uma 
redução significativa no período P3 que, segundo os resultados apresentados abaixo, não parece ter influenciado negativamente o desenvolvimento embrionário posterior. Após a remoção da zona pelúcida, bisecção manual e seleção por fluorescência, 2.755 (P1), 4.944 (P2) e 2.209 (P3) hemi-oócitos enucleados (hemi-citoplastos) foram utilizados para a reconstrução de hemi-embriões (50\% do volume citoplasmático, P1 e P2) e embriões (100\% do volume citoplasmático, os três períodos), sendo submetidos à fusão elétrica e formação dos grupos experimentais de embriões G1 e G2. As taxas de fusão de hemi-embriões (um hemicitoplasto + célula) no P1 e de embriões no P3 (dois hemi-citoplastos + célula) foram significativamente menores e maiores que a fusão nos demais períodos e grupos (G2 no P1 e G1 e G2 no P2), como evidenciado na tabela 7.1.

A taxa de clivagem de hemi-embriões agregados (G1) no P2 e de embriões (G2) no P3 foram superiores aos demais grupos e períodos, incluindo embriões do grupo de partenogênese, atingindo os menores índices para embriões (G2) no P1 (Tabela 7.1). A produção de blastocistos aumentou significativamente conforme o período, sendo de 15,5\% (124/798), 21,6\% (309/1428) e 36,6\% (280/764) para P1, P2 e P3, respectivamente, independente do tipo de embrião. Em termos globais, as taxas de blastocisto apresentaram um aumento de $39,4 \%$ do período $\mathrm{P} 1$ ao $\mathrm{P} 2$, e de $69,4 \%$ do $\mathrm{P} 2$ ao $\mathrm{P} 3$, representando um aumento global de mais de 2,4 vezes do início (15,5\%) ao final $(36,6 \%)$ dos três períodos. Não houve diferença significativa quanto ao desenvolvimento de embriões partenotos até o estádio de blastocisto entre os períodos, sendo esta taxa de desenvolvimento semelhante ao G2 no período P3, com os grupos G1 e G2 nos períodos P1 e P2 apresentando taxas de blastocisto significativamente menores do que aqueles grupos. As taxas de desenvolvimento apresentadas pelo grupo de embriões partenotos comprovaram a viabilidade do citoplasma e das condições in vitro no desenvolvimento posterior em cada procedimento e em cada período.

A eficiência relativa de produção de blastocistos por número de $\mathrm{CCO}$ iniciais em cada período (Tabela 7.1) demonstrou que a produção de embriões agregados (G1, 2 x 50\%) nos dois primeiros períodos foi similar e significativamente inferior aos demais grupos. Os grupos G2 (1 x 100\%) produzidos no P1 e P2 apresentaram eficiência similar, mas ainda inferior ao G2 do período P3. A eficiência do grupo de partenotos (embriões produzidos a partir de oócitos intactos, com zona pelúcida) foi significativamente superior a todos os grupos de embriões clonados. 
Tabela 7.1 - Taxas de fusão, clivagem e blastocisto para hemi-embriões agregados (G1, 2 x 50\%) e embriões (G2, 1 x 100\%) clones bovinos produzidos por TNCS, e para partenotos nos três períodos experimentais (P1, P2 e P3), entre os meses de janeiro de 2007 e maio de 2009, Laboratório de Reprodução Animal, UDESC Lages, SC - 2007-2009

\begin{tabular}{|c|c|c|c|c|c|c|c|c|c|c|}
\hline \multirow{2}{*}{ Período } & \multirow{2}{*}{ Grupo } & \multicolumn{2}{|c|}{ Fusão ${ }^{\dagger}$} & \multirow[t]{2}{*}{$\mathbf{n}^{\mathbf{T}}$} & \multicolumn{2}{|c|}{ Clivagem* } & \multicolumn{2}{|c|}{ Blastocisto* } & \multicolumn{2}{|c|}{$\begin{array}{c}\text { Eficiência } \\
\text { Relativa }^{¥}\end{array}$} \\
\hline & & $\mathbf{n}$ & $\%$ & & $\mathbf{n}$ & $\%$ & $\mathbf{n}$ & $\%$ & Razão & $\%$ \\
\hline $\mathrm{P} 1$ & G1 & $365 / 759$ & $48,1^{\mathrm{a}}$ & 165 & 126 & $76,4^{\mathrm{a}, \mathrm{b}}$ & 26 & $15,8^{\mathrm{a}}$ & $1: 92^{\mathrm{a}}$ & 1,1 \\
\hline (01-08/2007) & $\mathrm{G} 2$ & $651 / 958$ & $68,0^{\mathrm{b}}$ & 633 & 444 & $70,1^{\mathrm{a}}$ & 98 & $15,5^{\mathrm{a}}$ & $1: 31^{b}$ & 3,2 \\
\hline $\mathrm{P} 2$ & G1 & $1158 / 1690$ & $68,5^{\mathrm{b}}$ & $129^{€}$ & 113 & $87,6^{\mathrm{c}}$ & 26 & $20,2^{\mathrm{a}, \mathrm{b}}$ & $1: 56^{\mathrm{a}}$ & 1,8 \\
\hline$(12 / 2007-07 / 2008)$ & $\mathrm{G} 2$ & $957 / 1423$ & $67,3^{b}$ & $1299^{\circledR}$ & 1042 & $80,2^{b}$ & 283 & $21,8^{\mathrm{b}}$ & $1: 33^{\mathrm{b}}$ & 3,1 \\
\hline $\begin{array}{c}\text { P3 } \\
(10 / 2008-05 / 2009)\end{array}$ & G2 & $786 / 1023$ & $76,8^{\mathrm{c}}$ & 764 & 663 & $86,8^{\mathrm{c}}$ & 280 & $36,6^{\mathrm{c}}$ & $1: 18^{\mathrm{c}}$ & 5,5 \\
\hline $\mathrm{P} 1+\mathrm{P} 2+\mathrm{P} 3$ & Partenoto $^{\S}$ & - & - & 591 & 467 & $79,0^{\mathrm{b}}$ & 196 & $33,2^{\mathrm{c}}$ & $1: 5^{\mathrm{d}}$ & 20,6 \\
\hline
\end{tabular}

,b,c,d: Números nas colunas seguidos de letras desiguais diferem, para $\mathrm{P}<0,05$

${ }^{\dagger}$ Utilização do equipamento de eletrofusão Voltain ${ }^{\mathrm{TM}}$ EP-1 Cell Fusion System (Cryologic, Austrália) para o período P1, e do BTX Electro Cell Manipulator 200 (Biotechnologies \& Experimental Research Inc., San Diego, CA, EUA) para os períodos P2 e P3

${ }^{\mathrm{F}}$ Total de micro-poços (WOW) com embriões agregados (G1) ou embriões (G2) colocados em cultivo

*Baseando-se por WOW

${ }^{¥}$ Blastocistos por total de CCOs iniciais utilizados em cada grupo

${ }^{€} \mathrm{O}$ número menor de embriões colocados em cultivo em relação ao total de fusionados deve-se à alocação de hemi-oócitos para um experimento paralelo

${ }^{\circ} \mathrm{O}$ número maior de embriões colocados em cultivo dos que os que efetivamente fundiram deve-se a um ajuste neste grupo com respeito a outros tipos de esquemas de embriões agregados que apresentaram taxas de clivagem e blastocisto semelhantes ao G2

Somente embriões $1 \times 100 \%(\mathrm{G} 2)$ foram produzidos no período P3, para este experimento

${ }^{\S}$ Como não houve diferença em desenvolvimento entre os períodos para embriões partenotos, apresentou-se a média geral para os três períodos 
Nos períodos $\mathrm{P} 1$ e $\mathrm{P} 2$, do total de 34 rotinas realizadas, em cinco ocorreu a re-fusão de hemi-embriões (grupo G1), e em doze a re-fusão de embriões (grupo G2). As taxas de fusão das estruturas submetidas a uma ou duas fusões não diferiu no G1, mas foi significativamente maior para as estruturas que passaram por apenas uma fusão no G2, conforme apresentado na tabela 7.2. A taxa de clivagem não apresentou influência quanto ao número de fusões (uma ou duas) dentro dos grupos, mas o desenvolvimento a blastocisto foi afetado nos embriões do G1 que passaram pela re-fusão, enquanto que esta diferença não foi observada para o G2.

Tabela 7.2 - Taxas de fusão, clivagem e blastocisto para hemi-embriões agregados (G1, 2 x 50\%) e embriões (G2, 1 x 100\%) clones bovinos produzidos por TNCS submetidos ou não à re-fusão nos dois primeiros períodos experimentais (P1, P2), entre os meses de janeiro de 2007 e julho de 2008, Laboratório de Reprodução Animal, UDESC - Lages, SC - 2007-2008

\begin{tabular}{|c|c|c|c|c|c|c|c|c|c|}
\hline \multirow[b]{2}{*}{ Grupo } & \multirow{2}{*}{$\begin{array}{c}\text { Número } \\
\text { de } \\
\text { Fusões }\end{array}$} & \multirow{2}{*}{$\begin{array}{c}\text { Total } \\
\text { Reconstruído }\end{array}$} & \multicolumn{2}{|c|}{ Fusão } & \multirow[b]{2}{*}{$\mathbf{n}^{\mathbf{T}}$} & \multicolumn{2}{|c|}{ "Clivagem* } & \multicolumn{2}{|c|}{ Blastocisto" } \\
\hline & & & $\mathbf{n}$ & $\%$ & & n & $\%$ & $\mathbf{n}$ & $\%$ \\
\hline \multirow{2}{*}{ G1 } & 1 & 509 & 299 & $58,7^{b}$ & 75 & 59 & $78,7^{b}$ & 14 & $18,7^{\mathrm{c}}$ \\
\hline & 2 & $169^{\S}$ & 91 & $53,8^{\mathrm{ab}}$ & 32 & 21 & $65,6^{\mathrm{ab}}$ & 1 & $3,1^{\mathrm{a}}$ \\
\hline \multirow{2}{*}{$\mathrm{G} 2$} & 1 & 1081 & 772 & $71,4^{\mathrm{c}}$ & 713 & 418 & $58,6^{\mathrm{a}}$ & 76 & $10,7^{b}$ \\
\hline & 2 & $238^{\S}$ & 117 & $49,2^{\mathrm{a}}$ & 109 & 66 & $60,6^{\mathrm{a}}$ & 6 & $5,5^{\mathrm{ab}}$ \\
\hline
\end{tabular}

a,b,c: Números nas colunas seguidos de letras desiguais diferem, para $\mathrm{P}<0,05$

Fusões ocorridas na mesma rotina

${ }^{\mathrm{F}}$ Total de micro-poços (WOW) com embriões agregados (G1) ou embriões (G2) colocados em cultivo

*Baseando-se por WOW

${ }^{\S}$ Estruturas que não fusionaram e que foram submetidas à re-fusão posterior 


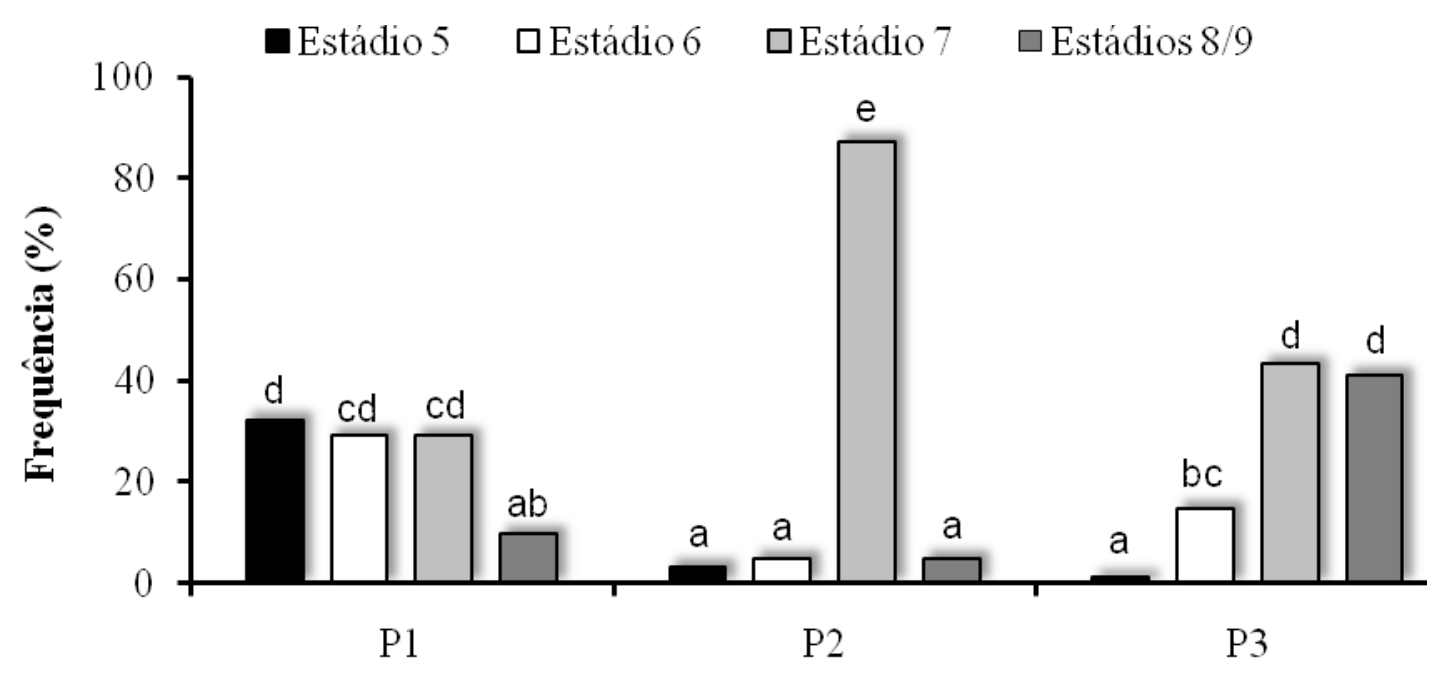

Períodos Experimentais

Figura 7.2 - Distribuição do estádio (Estádio 5: blastocisto inicial; Estádio 6: blastocisto; Estádio 7: blastocisto expandido; Estádios 8/9: blastocistos em eclosão ou eclodidos) dos embriões clones produzidos nos três períodos experimentais compilados. ${ }^{\text {a-e: }}$ Colunas com sobrescritos desiguais diferem, $\mathrm{p}<0,05$

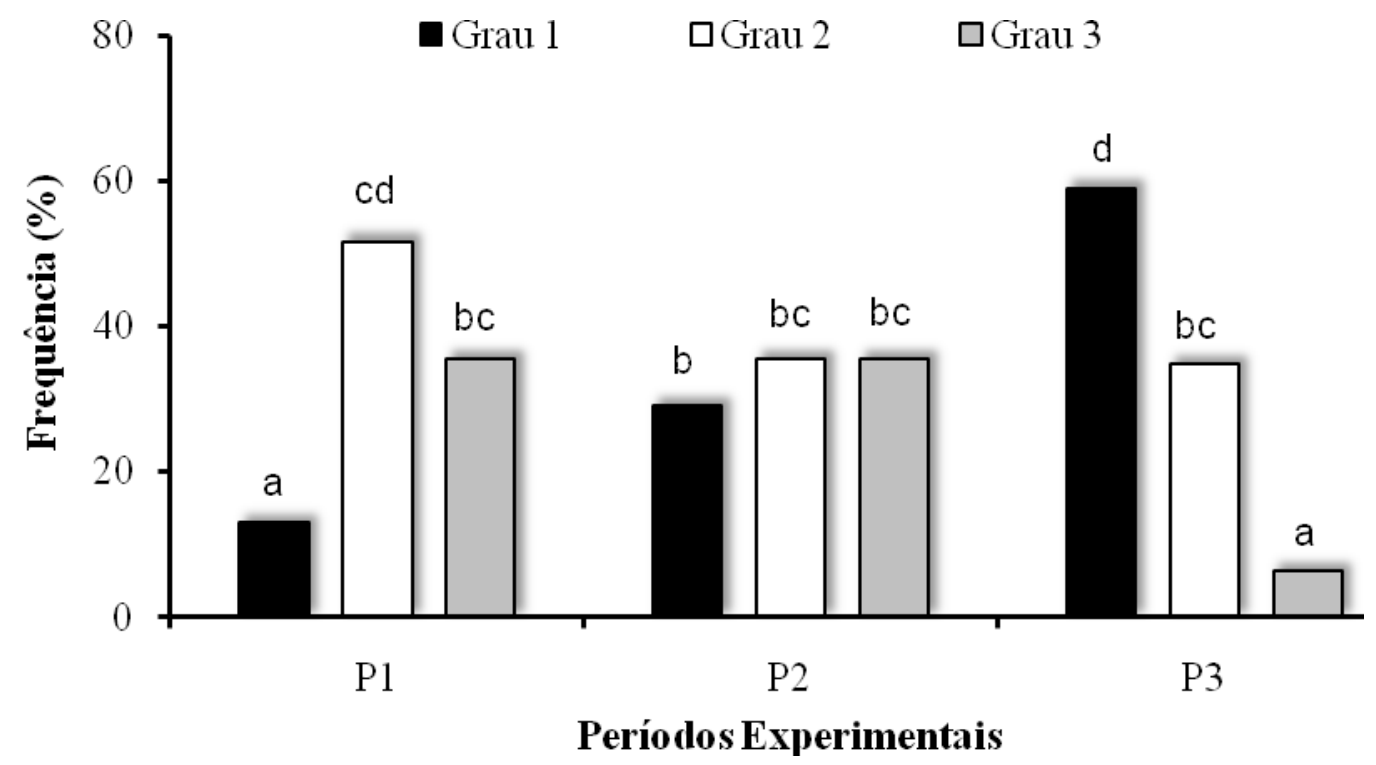

Figura 7.3 - Distribuição da qualidade (Grau 1, ótima; Grau 2, boa; Grau 3, ruim) dos embriões clones produzidos nos três períodos experimentais compilados. ${ }^{\text {a-d: }}$ Colunas com sobrescritos desiguais diferem, $\mathrm{p}<0,05$

As freqüências de estádio e qualidade de embriões produzidos em cada período experimental apresentadas na tabela 7.3 são ilustradas nas figuras 7.2 e 7.3. Os valores retratam apenas $20 \%$ dos embriões produzidos em cada período, compilados de forma aleatória de cada bloco, que representa um número muito semelhante aos que foram 
transferidos para fêmeas receptoras (Figura 7.4). No primeiro período (P1), o desenvolvimento embrionário atingiu estádios predominantemente mais iniciais, com cerca de 90\% dos embriões sendo classificados como blastocistos iniciais e expandidos, havendo uma distribuição homogênea entre estes estádios. Esta cinética de desenvolvimento se acelerou no segundo período, com 87,1\% (54/62) dos embriões encontrando-se no estádio 7. Seguindo a mesma tendência, uma evolução significativa foi observada no último bloco, com 43,2\% (41/95) e 41,1\% (39/95) dos embriões nos estádios 7 e 8/9, respectivamente, ou seja, 84,3\% (80/95) do total de blastocistos.

Quanto à qualidade dos embriões em cada período, uma significativa melhora (ou inversão de pior para melhor) foi observada no decorrer dos três períodos, conforme evidenciado na figura 7.3. No P1, a proporção de embriões em graus de pior qualidade foi significativamente maior, com 12,9\% (4/31), 51,6\% (16/31) e 35,5\% (11/31) de embriões classificados como graus 1, 2 e 3, respectivamente. Esta freqüência foi distribuída de forma mais homogênea no segundo período, com 29,0\% (18/62), 35,5\% (22/62) e 35,5\% (22/62) sendo classificados como graus 1, 2 e 3, respectivamente, com um aumento na qualidade sendo refletida em um aumento de embriões grau $1 \mathrm{em}$ detrimento do número de graus 2 . No período P3, da mesma maneira observada com a distribuição dos estádios embrionários, houve um expressivo e significativo aumento na porcentagem de embriões de melhor qualidade, com 58,9\% (56/95), sendo classificados como grau 1, 34,7\% (33/95) como grau 2 e $6,3 \%(6 / 95)$ como grau 3. O aumento na qualidade, neste caso, foi refletida por uma diminuição do número de embriões grau 3. O aumento da cinética de desenvolvimento e a melhora da qualidade embrionária são bem apresentados na tabela 7.3, onde a probabilidade de se obter um embrião em estádio 7 a 8/9 e qualidade 1 aumentou em 10 vezes do P1 ao P3, passando de 5,0\% no P1 (0,387 x 0,129, para estádio e qualidade, respectivamente) para $26,7 \%$ no P2 (0,919 x 0,290, para estádio e qualidade, respectivamente), culminando para 49,7\% no P3 (0,843 x 0,589, para estádio e qualidade, respectivamente). No P3, portanto, houve um aumento tanto na cinética do desenvolvimento quanto na qualidade embrionária dos blastocistos produzidos em relação aos períodos anteriores. 
Tabela 7.3 - Distribuição da freqüência relativa quanto a estádio e qualidade para embriões clones, e da eficiência relativa de desenvolvimento embrionário por total de oócitos, independente da reconstrução empregada nos três períodos experimentais (P1, P2 e P3), entre os meses de janeiro de 2007 e maio de 2009 , Laboratório de Reprodução Animal, UDESC - Lages, SC - 2007-2009

\begin{tabular}{|c|c|c|c|c|c|c|c|c|c|c|}
\hline \multirow[t]{2}{*}{ Período } & \multirow{2}{*}{$\begin{array}{c}\text { Blastocistos } \\
\mathbf{n}^{*}\end{array}$} & \multicolumn{4}{|c|}{ Estádio de Desenvolvimento } & \multicolumn{3}{|c|}{ Qualidade Embrionária ${ }^{€}$} & \multicolumn{2}{|c|}{$\begin{array}{c}\text { Eficiência Relativa } \\
\text { (blastocistos por total de } \\
\text { oócitos) }\end{array}$} \\
\hline & & 5 & 6 & 7 & $8 / 9$ & Grau 1 & Grau 2 & Grau 3 & $\begin{array}{c}\text { Oócitos } \\
\text { MII }^{\dagger}\end{array}$ & Total CCOs \\
\hline $\mathrm{P} 1$ & 31 & $0,323^{\mathrm{Aa}}$ & $0,290^{\mathrm{Aa}}$ & $0,290^{\mathrm{Aa}}$ & $0,097^{\mathrm{Ba}}$ & $0,129^{\mathrm{Aa}}$ & $0,516^{\mathrm{Ba}}$ & $0,355^{\mathrm{Ba}}$ & $\begin{array}{c}1: 29^{a} \\
(3,5 \%)\end{array}$ & $\begin{array}{c}1: 44^{\mathrm{a}} \\
(2,3 \%)\end{array}$ \\
\hline $\mathrm{P} 2$ & 62 & $0,032^{\mathrm{Ab}}$ & $0,048^{\mathrm{Ab}}$ & $0,871^{\mathrm{Bb}}$ & $0,048^{\mathrm{Aa}}$ & $0,290^{\mathrm{Ab}}$ & $0,355^{\mathrm{Aa}}$ & $0,355^{\mathrm{Aa}}$ & $\begin{array}{l}1: 22^{a} \\
(4,5 \%)\end{array}$ & $\begin{array}{l}1: 35^{\mathrm{a}} \\
(2,9 \%)\end{array}$ \\
\hline P3 & 95 & $0,011^{\mathrm{Ab}}$ & $0,147^{\mathrm{Ba}}$ & $0,432^{\mathrm{Ca}}$ & $0,411^{\mathrm{Cb}}$ & $0,589^{\mathrm{Ac}}$ & $0,347^{\mathrm{Ba}}$ & $0,063^{\mathrm{Cb}}$ & $\begin{array}{c}1: 10^{\mathrm{b}} \\
(10,1 \%)\end{array}$ & $\begin{array}{l}1: 18^{b} \\
(5,5 \%)\end{array}$ \\
\hline
\end{tabular}

"Independente do esquema de reconstrução empregado

*Estádio 5: blastocisto inicial; Estádio 6: blastocisto; Estádio 7: blastocisto expandido; Estádios 8/9: blastocistos em eclosão e eclodidos

${ }^{€}$ Grau 1: ótima; Grau 2: boa; Grau 3: ruim

Baseado nos oócitos maturados utilizados para clonagem

A,B,C: Dados na mesma linha, para estádio de desenvolvimento ou qualidade embrionária, sem o mesmo sobrescrito diferem, $\mathrm{P}<0,05$

${ }^{\text {a,b,c: }}$ Dados na mesma coluna sem o mesmo sobrescrito diferem, $\mathrm{P}<0,05$ 


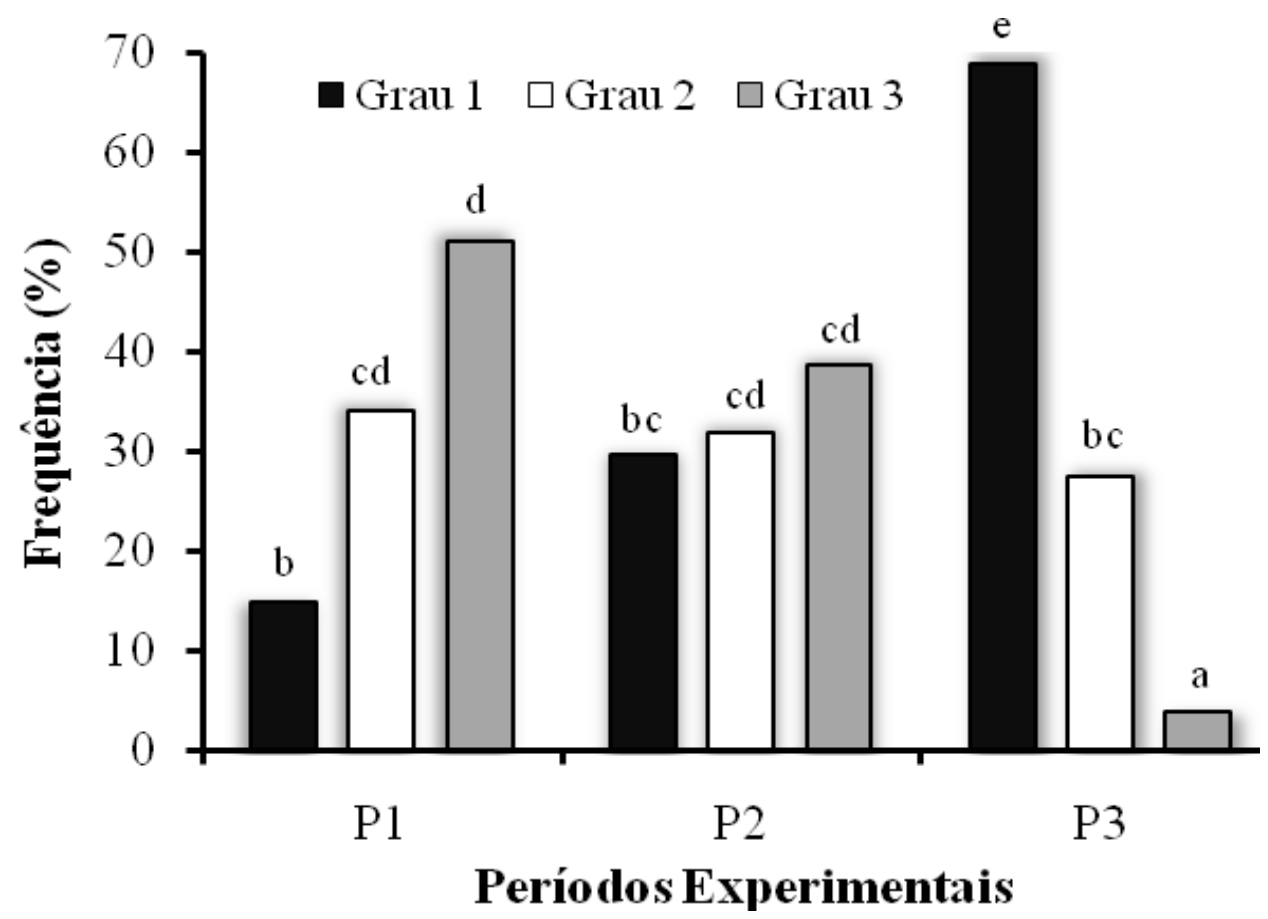

Figura 7.4 - Distribuição da qualidade (Grau 1: ótima, Grau 2: boa, Grau 3, ruim) dos embriões clones transferidos nos três períodos experimentais compilados. ${ }^{\text {a-e: }}$ Colunas com sobrescritos desiguais diferem, $\mathrm{p}<0,05$

A figura 7.4 ilustra a proporção de embriões classificados em graus 1, 2 e 3 e que foram transferidos para receptoras no decorrer dos três períodos de estudo. A proporção de embriões de qualidade ótima (1) e ruim (3) inverteram-se significativamente do P1 ao P3. No P1, 14,9\% (7/47), 34,0\% (16/47) e 51,1\% (24/47); no P2, 29,5\% (26/88), 31,8\% (28/88) e $38,6 \%$ (34/88); e no P3, 68,8\% (55/80), 27,5\% (22/80), e 3,8\% (3/80) dos embriões transferidos foram classificados em grau 1,2 e 3 , respectivamente.

A viabilidade embrionária in vivo foi avaliada após a transferência dos embriões clones para fêmeas receptoras síncronas, com as taxas de prenhez diferindo significativamente entre os três períodos, conforme evidenciado na tabela 7.4. No P1, um total de 47 embriões foi transferido para 30 receptoras resultando em duas prenhezes $(6,7 \%)$, apresentando-se como a pior taxa de prenhez das três estações de transferência. No P2 e P3, 88 e 80 embriões foram transferidos para 48 e 60 receptoras, respectivamente, produzindo $10(20,8 \%)$ e 24 (40,0\%) prenhezes no dia 30 de gestação. As perdas gestacionais acumuladas para cada período, entre os Dias 30 e 225 dias de prenhez, foram de 0,0\% (0/2), 80,0\% (8/10) e 79,2\% (19/24) para P1, P2 e P3, respectivamente. A eficiência relativa do estabelecimento de prenhezes aos 30 dias de gestação por número de CCOs iniciais utilizados aumentou 
significativamente de acordo com os períodos descritos, passando de $0,04 \%$ ( 1 prenhez para cada 2.716 CCOs) para $0,22 \%(1: 460)$ e finalmente para $0,47 \%(1: 212)$.

As duas prenhezes do P1 que mantiveram a viabilidade até os 225 dias abortaram no terço final da gestação (aproximadamente aos 230 e 245 dias de gestação). Uma das prenhezes do P2, oriunda de um embrião do grupo G1 (agregado, 2 x 50\%), foi acompanhada até os 289 dias, resultando no nascimento por cesariana eletiva de uma bezerra viável, no dia 9 de novembro de 2008, pesando 39,0 kg (Figura 7.5). A outra gestação deste período, proveniente de um embrião do grupo $\mathrm{G} 2$, e as cinco prenhezes do P3, todas as seis contendo conceptos viáveis, foram encerradas eletivamente aos 225 dias de gestação para a coleta de material biológico para o experimento descrito no Capítulo 3.

A análise de genotipagem por microssatélite do animal nascido para fins de validação e certificação da clonagem foi conduzida pela empresa Gene/Genealógica CGTA Ltda. (Belo Horizonte, MG, Brasil), sendo catalogada sob número de registro NEL02040. O genótipo se revelou idêntico para a doadora de célula e do clone, baseando-se nos 10 seguintes alelos: BM1824, BM2113, TGLA227, INRA23, TGLA122, TGLA126, BM1818, ETH10, ETH225, TGLA57. O possível grau próximo de parentesco com a receptora foi descartado, baseando-se em 6 loci diferentes dos 10 testados. 
Tabela 7.4 - Taxas de prenhez de embriões clones bovinos produzidos por TNCS, evolução de perdas gestacionais até o terceiro trimestre de gestação e eficiência relativa quanto ao número de CCOs iniciais nos três períodos apresentados, entre os meses de janeiro de 2007 e maio de 2009, Laboratório de Reprodução Animal, UDESC - Lages, SC - 2007-2009

\begin{tabular}{|c|c|c|c|c|c|c|c|c|c|c|c|c|c|}
\hline \multirow{3}{*}{ Período } & \multirow{3}{*}{$\mathbf{n}^{\mathbf{T}}$} & \multicolumn{10}{|c|}{ "Taxa de prenhez } & \multicolumn{2}{|c|}{ Eficiência Relativa $^{\ddagger}$} \\
\hline & & \multicolumn{2}{|c|}{ Dia 30} & \multicolumn{2}{|c|}{ Dia 45} & \multicolumn{2}{|c|}{ Dia 60} & \multicolumn{2}{|c|}{ Dia 150} & \multicolumn{2}{|c|}{ Dia 225} & \multirow{2}{*}{ Razão } & \multirow{2}{*}{$\%$} \\
\hline & & $\mathbf{n}$ & $\%$ & $\mathbf{n}$ & $\%$ & n & $\%$ & $\mathbf{n}$ & $\%$ & $\mathbf{n}$ & $\%$ & & \\
\hline $\begin{array}{c}\mathrm{P} 1 \\
(01-08 / 2007)\end{array}$ & 30 & 2 & $6,7^{\mathrm{a}}$ & 2 & 6,7 & 2 & 6,7 & 2 & 6,7 & 2 & 6,7 & $1: 2.716^{\mathrm{a}}$ & 0,04 \\
\hline $\begin{array}{c}\text { P2 } \\
(12 / 2007-07 / 2008)\end{array}$ & 48 & 10 & $20,8^{b}$ & 6 & 12,5 & 5 & 10,4 & 4 & 8,3 & 2 & 4,2 & $1: 460^{b}$ & 0,22 \\
\hline $\begin{array}{c}\text { P3 } \\
(10 / 2008-03 / 2009)\end{array}$ & 60 & 24 & $40,0^{\mathrm{c}}$ & 11 & 18,3 & 6 & 10,0 & 6 & 10,0 & 5 & 8,3 & $1: 212^{c}$ & 0,47 \\
\hline
\end{tabular}

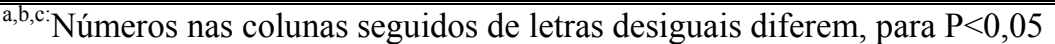

${ }^{\mathrm{F}}$ Número de receptoras

${ }^{¥}$ Número de prenhezes no dia 30 pelo total de CCOs iniciais em cada período 

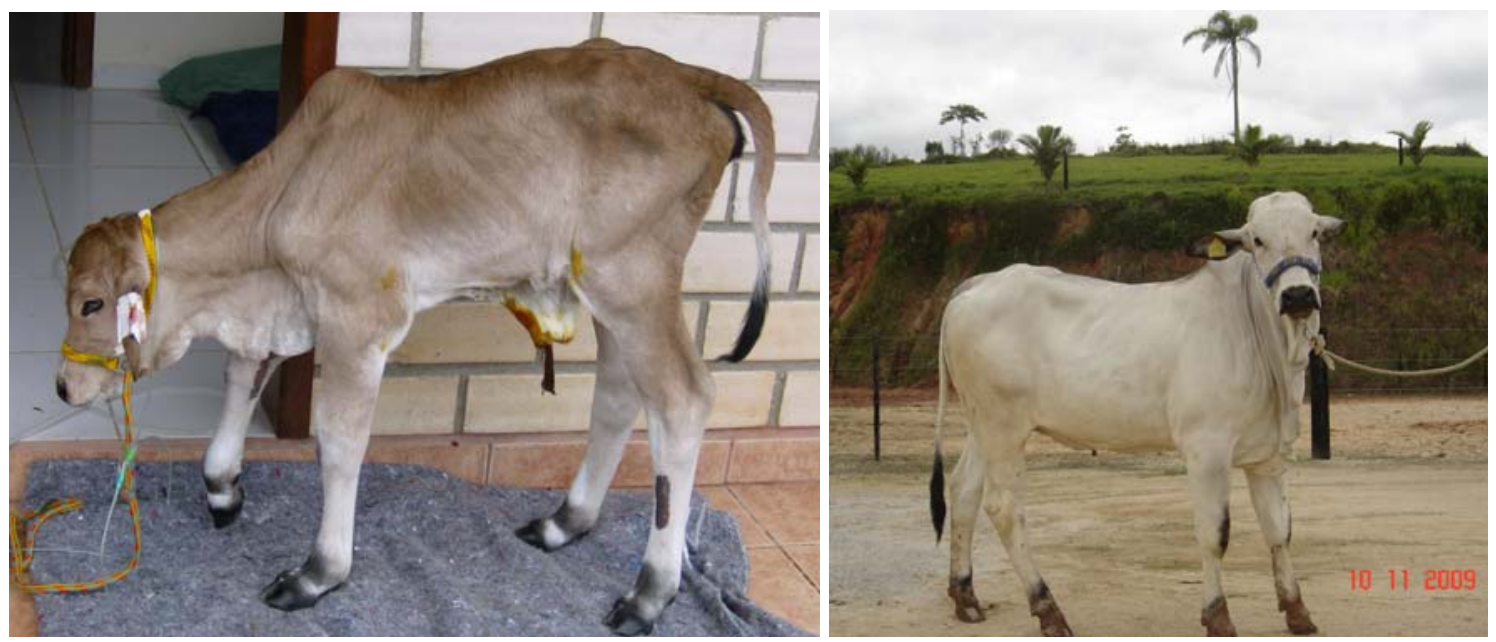

Figura 7.5 - Fêmea bovina Nelore ("Catarina") produzida por transferência nuclear pela metodologia do Handmade Cloning com $24 \mathrm{~h}$ (esquerda) e 1 ano (direita) de vida

\subsection{DISCUSSÃO}

A clonagem animal por transferência nuclear de célula somática, uma tecnologia com futuro promissor e uma gama grande de possibilidades (CAMPBELL et al., 2001), gerou uma imprevisível e sem precedente reação por parte da sociedade e da comunidade científica após o nascimento da ovelha Dolly (WILMUT et al., 1997) em julho de 1996. Apesar dos avanços na aplicação desta tecnologia em algumas espécies animais na última década, vários entraves técnicos e biológicos mantêm a sua eficiência geral ainda extremamente baixa, apresentando de forma geral, um alto custo operacional nos diversos laboratórios ao redor do mundo (VAJTA; ZHANG; MACHÁTY, 2007). A melhora do processo técnico como um todo, de detalhes inerentes a cada etapa e do conhecimento dos processos biológicos associados a esta tecnologia, visando fundamentalmente a produção de embriões que se assemelhem cada vez mais aos produzidos in vivo, possibilitará a redução nas taxas inesperadas de anormalidades de desenvolvimento tanto pré- quanto pós-natais, todas decorrentes deste procedimento (FARIN; PIEDRAHITA; FARIN, 2006; BERTOLINI et al., 2007). Em adição, a compreensão dos mecanismos de desvios nos processos biológicos também possibilitará a ampliação do uso desta técnica nas mais distintas áreas do conhecimento humano (CAMPBELL et al., 2001). 
Qualquer técnica ou processo de produção tem a sua eficiência diretamente associada à competência e habilidade do técnico que a executa (VARAGO; MENDONÇA; LAGARES, 2008). A TNCS/HMC, por ser uma biotécnica de conceito simples, mas composta por diversas etapas de relativa complexidade, necessita de optimização e de ajustes adequados para a obtenção de elevada repetibilidade em cada processo, a fim de que sejam obtidas taxas satisfatórias de produção e desenvolvimento embrionário que permitam a sua aplicação tanto na área científica quanto na comercial (CAMPBELL et al., 2007). Esta evolução gradual pode ser claramente observada nos procedimentos compilados em nosso laboratório no período de 28 meses. O número médio (por rotina) de CCOs empregados em cada um dos períodos foi de 339 (P1), 595 (P2) e 508 (P3), com um aumento significativo na eficiência de produção de embriões pelo número de CCOs iniciais empregados em cada grupo, conforme observado na tabela 7.1, e independente do grupo, considerando apenas o período, conforme observado na tabela 7.3, demonstrando o aumento da eficácia em se produzir um maior número de embriões com uma menor quantidade de estruturas empregadas em cada etapa do processo. O aumento das taxas de desenvolvimento a blastocisto em um mesmo laboratório no decorrer de diferentes experimentos também foi descrito por outros grupos de pesquisa (BATCHELDER et al., 2005), e atribuído ao aumento da competência com a aquisição de experiência técnica.

Além dos aspectos quantitativos, esta melhora da eficiência aparece em termos qualitativos, com um aumento de produção de embriões de melhor qualidade e de maior desenvolvimento produzidos no decorrer dos três períodos. Esta evolução fica bem exemplificada quando busca-se analisar a probabilidade de se produzir um blastocisto inicial (Estádio 5) de grau 3 no primeiro $(11,5 \%)$, segundo $(1,1 \%)$ e terceiro $(0,07 \%)$ períodos, enquanto que um excelente blastocisto eclodido (Estádio 9) de grau 1 aparece com 1,2\% (P1), 1,4\%(P2) e 24,2\% (P3) de freqüência. Dos embriões transferidos, uma taxa de 6,7\%, 20,8\% e 40,0\% de prenhez foi obtida aos 30 dias de gestação para os períodos P1, P2 e P3, respectivamente. Este aumento da prenhez é facilmente justificável pelo aumento significativo da transferência de embriões de melhor qualidade do P1 (14,9\%) ao P3 (51,1\%). Este aumento da transferência de embriões de melhor qualidade foi uma conseqüência natural de uma maior disponibilidade de embriões grau 1, do primeiro (12,9\%), ao segundo $(29,0 \%)$ e finalmente ao terceiro período (58,9\%). Farin e Farin (1995) e Chebel, Demétrio e Metzger (2008) demonstraram esta correlação positiva entre a qualidade do embrião transferido e a taxa de prenhez obtida utilizando embriões produzidos in vitro e in vivo, respectivamente. Estes resultados somente reforçam que a qualidade e estádio de desenvolvimento do embrião deve ser considerada como um importante fator na transferência de embriões, especialmente 
com os produzidos in vitro por TNCS, uma vez que estes fatores estão altamente correlacionados com o número total de células dos blastocistos (RIBEIRO et al., 2009). As taxas de prenhez nos três momentos deste experimento foram semelhantes às encontradas por Batchelder et al. (2005) que variaram de 10 a 46\%, dependendo do tipo celular e do grau de diferenciação das células empregadas. As perdas gestacionais de mais de $80 \%$ até os 225 dias nos P2 e P3 observadas, foram semelhantes às encontradas em uma ampla compilação realizada recentemente por Panarace et al. (2007), onde 75\% das perdas ocorreram dos 30 aos 210 dias, com apenas 9\% das 617 transferências mantendo gestações viáveis até o inicio do terço final da prenhez.

A fusão dos distintos componentes (célula doadora e citoplasto receptor) após a reconstrução é uma das etapas mais críticas do processo e está diretamente relacionada à eficiência geral da clonagem (VAJTA et al., 2005). A utilização de um único hemi-citoplasto (G1) no primeiro período resultou em uma fusão significativamente menor $(48,1 \%)$ que a fusão com dois hemi-citoplastos $(\mathrm{G} 2)$. Esta redução está provavelmente relacionada a três fatores: (a) tamanho das estruturas envolvidas; em geral, quanto maior a relação superfície:volume entre as estruturas, menor é o contato e a resposta ao alinhamento e fusão (TEISSIÉ et al., 1999); (b) aparelhos de eletrofusão diferentes para o P1 (Voltain ${ }^{\mathrm{tm}}$ ) e P2/P3 $\left(\mathrm{BTX}^{\circledR}\right)$; o segundo equipamento utilizado pareceu causar, em nossa experiência, um melhor alinhamento e fusão de estruturas do G1, visto que a taxa de fusão neste grupo no P1 foi menor que a do G2 do respectivo período, enquanto que no segundo período, ambos os grupos apresentaram taxas semelhantes; e (c) alinhamento das estruturas na câmara de eletrofusão; aparentemente, este foi o principal responsável pela redução na fusão neste experimento, visto que o grupo G1 do segundo período apresentou taxas semelhantes aos demais grupos, demonstrando uma maior competência técnica adquirida com o tempo em alinhar adequadamente as estruturas. Vajta et al. (2002) demonstraram que o alinhamento adequado das estruturas antes do pré-pulso (AC) resultou em taxas de fusão superiores (94\%) quando comparadas com o alinhamento ao acaso (54\%). Em nossas condições, a reconstrução do embrião com 100\% do volume citoplasmático (G2, 1 x 100\%) foi realizada primeiramente pela adesão de um hemi-citoplasto à célula doadora, seguido da junção de outro hemicitoplasto oposto à célula doadora, visando um alinhamento linear perfeito das três estruturas, com a célula permanecendo na extremidade do conjunto em reconstrução (Figura 7.1). Este tipo de reconstrução, por produzir melhores resultados na fusão em nossas condições (dados não publicados), difere do preconizado por Vajta et al. (2003), onde a reconstrução alocava a célula entre os dois hemi-citoplastos. Apesar da mudança de aparelhos de eletrofusão do 
primeiro para o segundo período, este aumento da competência técnica fica também visível com a fusão apresentada pelo grupo G2 no último período, sendo a maior de todos os grupos, com $76,8 \%$.

Visando aumentar o número de estruturas em cultivo e melhor aproveitamento de material biológico, optou-se pela re-fusão das estruturas que não fusionaram completamente no primeiro choque em algumas rotinas que apresentaram baixas taxas de fusão. A taxa de refusão do G1 apresentou-se semelhante à fusão única, enquanto que no G2, a taxa de re-fusao foi menor que a fusão. $\mathrm{O}$ desenvolvimento das estruturas re-fundidas foi menor no grupo G1, mas não diferiu no G2, e apesar de apenas sete embriões terem sido produzidos, os mesmos foram transferidos para receptoras, mas não resultaram em prenhezes. Estas taxas demonstram que é exeqüível produzir embriões viáveis de estruturas re-fusionadas. Entretanto, o tempo necessário para avaliar a fusão, re-fundir e re-avaliar, acaba se tornando inviável e desgastante no final do processo, além de reduzir o tempo de reprogramação, em se optando em ativar os embriões em um mesmo momento. Sendo assim, será que a re-fusão compensa? Em nossa experiência, a resposta é: depende. Se o número de oócitos for pequeno, se a espécie em questão apresentar elevada dificuldade ou custo de obtenção de oócitos, se a rotina é crucial para a obtenção de prenhezes, a resposta é sim; senão, não vale a pena em se tratando de bovinos ou outras espécies, quando a quantidade de oócitos for abundante.

A intenção de avaliar o potencial de desenvolvimento de embriões agregados (G1, dois hemi-embriões) baseou-se em estudos que buscaram melhorar as taxas de desenvolvimento e/ou a qualidade dos embriões, com possível efeito nas taxas de prenhez (BOIANI et al., 2003; TECIRLIOGLU et al., 2005; MISICA-TURNER et al., 2007; RIBEIRO et al., 2009). Porém, neste experimento, a agregação ocorreu logo após a ativação com estruturas com $50 \%$ do volume citoplasmático, re-formando uma estrutura por agregação com $100 \%$ de volume, enquanto que nos demais estudos, as agregações ocorreram em estádios mais avançados ou com estruturas que reconstituíram embriões com 150\%, 200\% ou mais de volume citoplasmático final. Nossa intenção foi de avaliar a competência de desenvolvimento de estruturas com esta configuração $(2 \times 50)$, avaliando-se o possível efeito complementar parácrino de cada hemi-embrião sobre o outro, reduzindo também fatores negativos quando da fusão de dois hemi-oócitos incompatíveis para a reconstrução de embriões do grupo G2 (1 x 100\%). Em camundongos, Boiani et al. (2003) verificaram que a agregação de embriões não aumentou a taxa de blastocisto, mas incrementou a densidade celular e o desenvolvimento in vivo subseqüente. Naquele estudo, a melhora no desenvolvimento in vivo não foi considerada como uma conseqüência do aumento do número 
de células, mas como um efeito aditivo positivo da agregação de embriões epigeneticamente diferentes. Neste trabalho, observou-se um desenvolvimento semelhante entre G1 e G2 até o estádio de blastocisto, em cada período. Porém, como a taxa de fusão para os hemi-embriões foi menor, a eficiência final de produção de blastocistos, por número de CCOs inicial, foi menor. Independente disto, o nascimento da fêmea clone "Catarina" foi a partir de um embrião do grupo G1, com boa viabilidade pós-natal e características físicas e clínicas moderadas quando comparados aos possíveis fenótipos e manifestações clínicas observadas em clones por TNCS (CHAVATTE-PALMER et al., 2004; BATCHELDER et al., 2007a,b; BERTOLINI et al., 2007; MEIRELLES et al., 2010). Porém, não podemos afirmar se as características físicas e clínicas daquele animal foram uma manifestação direta ou não da origem do embrião ( $2 \times 50 \%$ ). Mais estudos serão necessários para que esta hipótese seja testada.

Esta compilação de um período relativamente longo de rotinas de trabalho em clonagem bovina demonstrou claramente o efeito da experiência e da aquisição de competência técnica sobre os resultados de produção in vitro de embriões por TNCS, com repercussão direta no desenvolvimento in vivo posterior. Comprovou-se também a exeqüibilidade da produção de embriões e do nascimento de bovinos por TNCS utilizando a metodologia do HMC em nossas condições, viabilizando o nascimento do primeiro clone bovino da raça Nelore no Brasil por esta técnica. Apesar dos números serem reduzidos, os trabalhos com agregação de embriões e de hemi-embriões também mostram-se promissores como alternativa para melhorar o potencial de desenvolvimento in vitro e in vivo de embriões clonados por HMC. 


\section{CONSIDERAÇÕES FINAIS}

Uma expressiva quantidade de pesquisadores e de empresas comerciais que utilizam a produção in vitro de embriões, seja pela fecundação ou por transferência nuclear, especialmente em bovinos, relata anormalidades, de maior ou menor gravidade, no desenvolvimento posterior de conceptos provenientes de embriões produzidos in vitro. $\mathrm{Da}$ mesma forma, muitas destas alterações também foram encontradas em ambos os grupos in vitro deste estudo, independente do momento da gestação analisado. Como qualquer outra biotecnologia desenvolvida pelo homem, as variáveis técnicas e biológicas que estão envolvidas em cada etapa do procedimento, afetam tanto qualitativamente quanto quantitativamente o processo como um todo, interferindo na eficiência ou no sucesso do resultado final. A busca por uma produção de embriões com melhor qualidade e em maior quantidade, nos levou a conduzir os experimentos descritos nos Capítulos 1 e 2 .

Primeiramente, conforme apresentado no Capítulo 1, procurou-se melhorar a sincronização do ciclo celular da célula doadora de núcleo, com o objetivo de obter uma maior proporção de células nas fases G0/G1, consideradas por muitos investigadores como mais apropriadas para a adequada reprogramação do genoma, e que apresentam uma boa sincronia com oócitos receptores de núcleo na fase MII do ciclo, visto que estes seriam os citoplastos disponíveis em abundância para a produção deste grupo experimental. Aproveitando a disponibilidade de animais de duas raças presentes no local de condução dos experimentos, e de que ainda não havíamos definido quais células iríamos utilizar no protocolo de clonagem, comparamos a eficiência de cada cultivo na produção de embriões. As melhores taxas foram obtidas com a utilização de células com elevada confluência em cultivo, 24 horas antes do procedimento de clonagem, e com o emprego das células da fêmea da raça Nelore. Os resultados destes primeiros experimentos nos ajudaram a definir alguns parâmetros e a estabelecer a PIV de embriões por TNCS em nosso laboratório, garantindo os embriões para o estabelecimento de prenhezes neste grupo experimental.

Entretanto, tendo em vista as já esperadas menores taxas de prenhez e maiores perdas gestacionais para este grupo, a necessidade de melhorar as características morfológicas destes embriões se fez presente. Sendo assim, buscamos avaliar no Capítulo 2 se um maior intervalo entre a fusão e ativação dos embriões reconstruídos, e se a agregação de embriões no momento do cultivo promoveria maiores taxas de blastocisto no dia 7 de desenvolvimento, e se os mesmos estariam em estádios mais avançados e com melhor qualidade, repercutindo 
diretamente no desenvolvimento in vivo posterior. De fato, a agregação dos embriões e um maior intervalo entre fusão-ativação promoveram um incremento na produção de blastocistos. Contudo, estes não se apresentaram mais desenvolvidos ou com melhor qualidade, e também não influenciaram nas taxas de prenhez ou de manutenção subseqüente após a transferência para fêmeas receptoras síncronas.

Todavia, se analisarmos toda a produção de embriões e de prenhezes deste estudo, os resultados apresentados no Capítulo 2 referem-se ao terceiro e último período dos três discutidos no Capítulo 4, e demonstram uma significativa melhora nas características morfológicas em comparação aos períodos anteriores, independentemente das características e condições de cultivo de cada momento. Ademais, é nítida a evolução da produção in vitro de embriões e do estabelecimento de prenhezes no grupo TNCS entre os três períodos analisados no Capítulo 4. Estes resultados, compilados de um longo período (28 meses) de produção, comprovam o efeito direto da experiência e da aquisição de competência técnica sobre a eficiência e sucesso de uma biotecnologia, visto que com a exceção da variável tempo, nenhuma outra mudança ocorreu no protocolo de PIV de embriões, cabendo estas melhoras qualitativas e quantitativas apenas aos técnicos envolvidos.

Se observarmos individualmente os seis clones abatidos aos 225 dias de gestação de forma cronológica, esta evolução do procedimento com significativas melhoras quantitativas e em especial qualitativas, parece ter se repercutido no desenvolvimento posterior. Dos seis clones abatidos, nenhum pertencia ao primeiro período, e apenas o Clone 1 pertencia ao segundo período descrito no Capítulo 4. Este animal, com $42 \mathrm{~kg}$, apresentou o maior peso de todos e possivelmente o maior trato gravídico, já que não se pôde medir o volume de líquido presente em seu interior pelo rompimento uterino no momento da coleta. Se uma projeção fosse realizada baseando-se na estimativa de que $63 \%$ do peso destes animais seriam adquiridos até o momento do parto, visto que o peso médio do grupo Controle foi de $12,5 \mathrm{~kg}$ aos 225 dias (Capítulo 3) e de que o valor esperado ao nascimento para esta raça é de $34 \mathrm{~kg}$, a expectativa seria de que este primeiro clone alcançasse os $114 \mathrm{~kg}$, um valor incompatível com a manutenção da vida tanto fetal quanto materna. Dos outros cinco clones, é muito provável que apenas dois ou três chegassem a termo, e interessantemente, estes seriam os últimos que foram abatidos. Esta estimativa baseia-se nas alterações encontradas nos Clones 2 e 3, o primeiro e segundo clones do terceiro período, respectivamente. O Clone 2 com $71 \mathrm{~L}$ de fluidos fetais e o Clone 3 com $35 \mathrm{~kg}$ de peso, provavelmente morreriam nas semanas antecedentes ao parto, pelo elevado tamanho que o trato uterino e o feto alcançariam, e pelo comprometimento fisiológico também da mãe. Apesar do tamanho aumentado em relação aos 
Controles, e de algumas alterações encontradas tanto no feto quanto na placenta e membranas fetais, os Clones 4, 5 e 6 teriam as maiores chances de chegar a termo, por não terem apresentado graves anormalidades até então. Baseando-se nos trabalhos publicados anteriormente e da elevada mortalidade no período peri-natal, é muito provável que apenas um de todos estes animais conseguisse sobreviver às primeiras semanas de vida. Estas observações são apenas conjecturas da imensa possibilidade de eventos que poderiam ocorrer neste final da prenhez, e que exemplificam o grande espectro de alterações que podem acometer conceptos produzidos in vitro, e de forma mais acintosa os clones.

Esta grande variedade de alterações foi demonstrada no Capítulo 3, produzindo diferenças entre os grupos Controle, FIV e TNCS, em todas as fases da gestação analisadas. Os grupos in vitro (FIV e TNCS) apresentaram menores taxas de prenhez aos 30 dias, e o grupo TNCS as maiores perdas gestacionais em todos os momentos avaliados. As imagens obtidas por ultrasonografia aos 51 dias revelaram conceptos in vitro retardados em seu desenvolvimento. Este retardo, associado às elevadas perdas embrionárias e fetais precoces, são provavelmente decorrentes de um desenvolvimento e estabelecimento inadequado da placenta e corroboram com os resultados apresentados por outros pesquisadores. Os conceptos que sobreviveram a este período de restrição inicial apresentaram um crescimento compensatório posterior, já que as prenhezes produzidas in vitro, e especialmente as do grupo TNCS, sustentaram não só maiores conceptos e com maiores anormalidades aos 225 dias de gestação, como também apresentaram um maior acúmulo de substratos energéticos no sistema fetal. Estes resultados também corroboram com os apresentados na literatura, reforçando a teoria de que em decorrência das condições de produção in vitro e acentuadas no processo de clonagem, um inadequado estabelecimento placentário ocorre nos primeiros dias de gestação, resultando em elevadas perdas no terço inicial e em anormalidades fetais e placentárias no terço final, incluindo um crescimento compensatório dos fetos por uma falha da capacidade de regulação da restrição placentária.

Este trabalho demonstrou que a produção in vitro de embriões ainda necessita ser melhorada, com o desenvolvimento de protocolos que se assemelhem à produção in vivo de embriões, e que estas biotecnologias conduzem a anormalidades e distúrbios apresentados e observados em todo o período gestacional. Por mais que tenhamos procurado optimizar as condições dos componentes envolvidos no processo de clonagem, tanto de algumas variáveis biológicas quanto técnicas, este procedimento ainda é ineficiente e necessita de substanciais ajustes em todas as etapas, visando principalmente uma reprogramação nuclear mais adequada ao desenvolvimento in vitro e in vivo posterior. 


\section{CONCLUSÕES}

Neste estudo, o desenvolvimento anormal de conceptos após a manipulação in vitro de embriões por FIV e TNCS, especialmente no segundo grupo, foi demonstrado em distintas fases da gestação analisadas. Placentônios subdesenvolvidos caracterizaram uma alteração na formação da placenta que, provavelmente, foi a responsável por um desenvolvimento retardado de conceptos produzidos in vitro, e de uma elevada mortalidade no terço inicial da gestação, particularmente no grupo TNCS. Este retardado no desenvolvimento inicial foi compensado por um crescimento acelerado no terço final da gestação, por uma perda da capacidade de regulação da restrição placentária, já que as prenhezes produzidas in vitro, e especialmente as do grupo TNCS, sustentaram não só maiores conceptos e com maiores anormalidades aos 225 dias de gestação, como também apresentaram um maior acúmulo de substratos energéticos no sistema fetal.

As conclusões pertinentes a cada Capítulo seguem descritas abaixo:

(a) Houve uma influência significativa do núcleo doador no desenvolvimento de embriões clonados, com células de Crioulo Lageano sendo menos viáveis, nas condições de nosso experimento, para dar suporte ao desenvolvimento até o estádio de blastocisto do que células de Nelore;

(b) Um efeito linear positivo do nível de confluência celular próximo ou na fase de platô da curva de crescimento celular foi observado no desenvolvimento in vitro de embriões após a clonagem. Ademais, a inibição do crescimento por contato das células demonstrou ser um eficiente método para a sincronização do ciclo celular prévio à clonagem;

(c) Um maior intervalo de fusão-ativação dos presumíveis zigotos propiciou melhores taxas de desenvolvimento a blastocisto baseando-se no número de micro-poços utilizados. Mas não houve efeito na produção de embriões de melhor qualidade ou em estádios mais desenvolvidos, tampouco interferindo nas taxas de prenhez ou de manutenção das prenhezes após a transferência para receptoras; 
(d) A agregação de embriões no momento do cultivo propiciou melhores taxas de desenvolvimento a blastocisto baseando-se no número de micro-poços utilizados, mas sem efeitos benéficos no desenvolvimento in vitro e in vivo posterior;

(e) O grupo Controle apresentou uma maior taxa de prenhez aos 30 dias de gestação em relação aos grupos in vitro (FIV e TNCS) que não diferiram entre si. O grupo TNCS apresentou as maiores taxas de perdas gestacionais subseqüentes até os 225 dias, com as perdas do grupo Controle e FIV sendo menores e similares entre si;

(f) Os conceptos dos grupos in vitro apresentaram um desenvolvimento retardado aos 51 dias, mas com um crescimento compensatório posterior, já que as prenhezes produzidas in vitro, e especialmente as do grupo TNCS, sustentaram maiores conceptos e com maiores anormalidades aos 225 dias de gestação;

(g) A concentração e quantidade total de glicose não diferiram entre os três grupos nos compartimentos maternos e fetais aos 225 dias de gestação, mas a quantidade total de frutose e de ambos os carboidratos no alantóide foi maior no grupo TNCS em relação ao Controle;

(h) As elevadas correlações entre as imagens aos 51 dias e os dados morfométricos coletados aos 225 dias comprovam que as mensurações ultrasonográficas referentes às características dos conceptos produzidos in vitro, nos primeiros dois meses gestacionais de bovinos, podem predizer algumas alterações que compõe a síndrome dos neonatos anormais no terço final da gestação. Entretanto, estas correlações não apareceram para as concentrações e quantidades totais de substratos aos 225 dias;

(i) Do primeiro ao terceiro período, uma evolução positiva tanto qualitativa quanto quantitativa foi observada nos resultados obtidos de nosso laboratório, com um aumento da quantidade e da qualidade dos embriões produzidos e transferidos, incrementando o número de prenhezes estabelecidas em cada momento; e

(j) A compilação de um período relativamente longo de rotinas de trabalho em clonagem bovina demonstrou claramente o efeito da experiência e da aquisição de competência técnica sobre os resultados de produção in vitro de embriões por TNCS, com repercussão direta no desenvolvimento in vivo posterior. 


\section{REFERÊNCIAS}

ABIEC. Associação Brasileira das Indústrias Exportadoras de Carnes. Pecuária brasileira. [200_]. Disponível em: http:www.abiec.com.br/3_pecuaria.asp>. Acesso em: 10 fev. 2010.

ALBERIO, R.; CAMPBELL, K. H. S.; JOHNSON, A. D. Reprogramming somatic cells into stem cells. Reproduction, v. 132, n. 5, p. 709-720, 2006.

ALDORETTA, P. W.; HAY JR, W. W. Effect of glucose supply on ovine uteroplacental glucose metabolism. The American Journal of Physiology - Regulatory Integrative and Comparative Physiology, v. 277, n. 46, p. 947-958, 1999.

ANUALPEC: Anuário da pecuária brasileira. São Paulo: Finep Consultoria \& Comércio, 2009.

ARNOLD, D. R.; BORDIGNON, V.; LEFEBVRE, R.; MURPHY, B. D.; SMITH, L. C. Somatic cell nuclear transfer alters peri-implantation trophoblast differentiation in bovine embryos. Reproduction. v. 132, n. 2, p. 279-290, 2006.

ARTHUR, G. H. The fetal fluids of domestic animals. Journal of Reproduction and Fertility, v. 9, p. 45-52, 1969. Supplement.

BAGUISI, A.; BEHBOODI, E.; MELICAN, D. T.; POLLOCK, J. S.; DESTREMPES, M. M.; CAMMUSO, C.; WILLIAMS, J. L.; NIMS, S. D.; PORTER, C. A.; MIDURA, P.; PALACIOS, M. J.; AYRES, S. L.; DENNISTON, R. S.; HAYES, M. L.; ZIOMEK, C. A.; MEADE, H. M.; GODKE, R. A.; GAVIN, W. G.; OVERSTROM, E. W.; ECHELARD, Y. Production of goats by somatic cell nuclear transfer. Nature Biotechnology, v. 17, n. 5, p. 456-461, 1999.

BARKER, D. J. P. Fetal programming and public health. In: O’BRIEN, P. M. S.; WHEELER, T.; BARKER, D. J. P. (Ed.). Fetal programming: influences on development and disease in later life. London: RCOG Press, 1999. p. 3-11.

BARRETO, R. S. N.; MIGLINO, M. A.; MEIRELlES, F. V.; VISINTIN, J. A.; SILVA, S. M.; BURIOLI, K. C.; FONSECA, R.; BERTAN, C.; ASSIS NETO, A. C.; PEREIRA, F. T. V. Caracterização da fusão caruncular em gestações naturais e de conceptos bovinos clonados. Pesquisa Veterinária Brasileira, v. 29, n. 10, p. 779 $787,2009$.

BARUSELli, P. S.; FERREIRA, R. M.; FILHO, M. F.; NASSER, L. F.; RODRIGUES, C. A.; BÓ, G. A. Bovine embryo transfer recipient synchronisation and management in tropical environments. Reproduction, Fertility and Development, v. 22, n. 1, p. 67-74, 2010.

BATCHELDER, C. A.; HOFFERT, K. A.; BERTOLINI, M.; MOYER, A. L.; MASON, J. B.; PETKOV, S. G.; FAMULA, T. R.; ANDERSON, G. B. Effect of the nuclear-donor cell lineage, type, and cell donor on development of somatic cell nuclear transfer embryos in cattle. Cloning and Stem Cells, v. 7, n. 4, p. 238-254, 2005 .

BATCHELDER, C. A.; BERTOLINI, M.; MASON, J. B.; MOYER, A. L.; HOFFERT, K. A.; PETKOV, S. G.; FAMULA, T. R.; ANGELOS, J.; GEORGE, L. W.; ANDERSON, G. B. Perinatal physiology in cloned and normal calves: physical and clinical characteristics. Cloning and Stem Cells, v. 9, n. 1, p. 63-82, 2007a.

BATCHELDER, C. A.; BERTOLINI, M.; MASON, J. B.; MOYER, A. L.; HOFFERT, K. A.; PETKOV, S. G.; FAMULA, T. R.; ANGELOS, J.; GEORGE, L. W.; ANDERSON, G. B. Perinatal physiology in cloned and normal calves: hematologic and biochemical profiles. Cloning and Stem Cells, v. 9, n. 1, p. 83-96, $2007 \mathrm{~b}$. 
BEHBOODI, E.; ANDERSON, G. B.; BONDURANT, R. H.; CARGILL, S. L.; KREUSCHER, B. R.; MEDRANO, J. F.; MURRAY, J. D. Birth of large calves that developed from in vitro-derived bovine embryos. Theriogenology, v. 44, n. 2, p. 227-232, 1995.

BELL, A. W.; HAY, W. W.; EHRHARDT, R. A. Placental transport of nutrients and its implications for fetal growth. Journal of Reproduction and Fertility, v. 54, p. 401-410, 1999. Supplement.

BÉNYEI, B.; KOMLÓSI, I.; PÉCSI, A.; POLLOTT, G.; MARCOS, C. H.; DE OLIVEIRA CAMPOS, A.; LEMES, M. P. The effect of internal and external factors on bovine embryo transfer results in a tropical environment. Animal Reproduction Science, v. 93, n. 3-4, p. 268-279, 2006.

BERTOLINI, M.; ANDERSON, G. B. The placenta as a contributor to production of large calves. Theriogenology, v. 57, n. 1, p. 181-187, 2002.

BERTOLINI, M.; BEAM, S. W.; SHIM, H.; BERTOLINI, L. R.; MOYER, A. L.; FAMULA, T. R.; ANDERSON, G. B. Growth, development and gene expression by in vivo- and in vitro-produced day-7 and day16 bovine embryos. Molecular Reproduction and Development, v. 63, n. 3, p. 318-328, 2002 b.

BERTOLINI, M.; BERTOLINI, L. R.; GERGER, R. P. C.; BATCHELDER, C. A.; ANDERSON, G. B. Developmental problems during pregnancy after in vitro embryo manipulations. Revista Brasileira de Reprodução Animal, v. 31, p. 391-405, 2007.

BERTOLINI, M.; MASON, J. B.; BEAM, S. W.; CARNEIRO, G. F.; SWEEN, M. L.; MOYER, A. L.; FAMULA, T. R.; SAINZ, R. D.; ANDERSON, G. B. Morphology and morphometry of in vivo- and in vitroproduced bovine concepti from early pregnancy to term and association with high birth weights.

Theriogenology, v. 58, n. 1, p. 973-994, 2002a.

BERTOLINI, M.; MOYER, A. L.; MASON, J. B.; BATCHELDER, C. A.; HOFFERT, K. A.; BERTOLINI, L. R.; CARNEIRO, G. F.; CARGILL, S. L.; FAMULA, T. R.; CALVERT, C. C.; SAINZ, R. D.; ANDERSON, G. B. Evidence of increased substrate availability to in vitro-derived bovine foetuses and association with accelerated conceptus growth. Society for Reproduction and Fertility, v. 128, n. 3, p. 341-354, 2004.

BERTOLINI, M.; WALLACE, C. R.; ANDERSON, G. B. Expression profile and protein levels of placental products as indirect measures of placental function in in vitro-derived bovine pregnancies. Reproduction, $\mathrm{v}$. 131, n. 1, p. 163-173, 2006.

BERTRAM, C. A.; HANSON, M. A. Animal models and programming of the metabolic syndrome. British Medical Bulletin, v. 60, p. 103-121, 2001.

BOIANI, M.; ECKARDT, S.; LEU, N. A.; SCHÖLER, H. R.; MCLAUGHLIN, K. J. Pluripotency deficit in clones overcome by clone-clone aggregation: epigenetic complementation? The EMBO Journal, v. 22, n. 19, p. 5304-5312, 2003.

BOQUEST, A. C.; DAY, B. N.; PRATHER, R. S. Flow cytometric cell cycle analysis of cultured porcine fetal fibroblast cells. Biology of Reproduction, v. 60, n. 4, p. 1013-1019, 1999.

BORDIGNON, V.; SMITH, L. C. Telophase enucleation: an improved method to prepare recipient cytoplasts for use in bovine nuclear transfer. Molecular Reproduction and Development, v. 49, n. 1, p. 29-36, 1998.

BOURC'HIS, D.; LE BOURHIS, D.; PATIN, D.; NIVELEAU, A.; COMIZZOLI, P.; RENARD, J. P.; VIEGASPEQUIGNOT, E. Delayed and incomplete reprogramming of chromosome methylation patterns in bovine cloned embryos. Current Biology, v. 11, n. 19, p. 1542-1546, 2001.

BRACKETT, B. G.; BOUSQUET, D.; BOICE, M. L.; DONAWICK, W. J.; EVANS, J. F.; DRESSEL, M. A. Normal development following in vitro fertilization in the cow. Biology of Reproduction, v. 27, n. 1, p. 147$158,1982$. 
CAMPBELL, K. H. S. Cell cycle regulation in cloning. In: CIBELLI, J.; LANZA, R. P.; CAMPBELL, K. H. S.; WEST, M. D. (Ed.). Principles of cloning. San Diego: Academic Press, 2002. p. 391-399.

CAMPBELL, K. H. S.; ALBERIO, R.; CHOI, I.; FISHER, P.; KELLY, R. D. W.; LEE J. H.; MAALOUF, W. Cloning: eight years after Dolly. Reproduction in Domestic Animals, v. 40, n. 4, p. 256-268, 2005.

CAMPBELL, K. H. S.; ALBERIO, R.; LEE, J. H.; RITCHIE, W. A. Nuclear transfer in practice. Cloning and Stem Cells, v. 3, n. 4, p. 201-208, 2001.

CAMPBELL, K. H. S.; FISHER, P.; CHEN, W. C.; CHOI, I.; KELLY, R. D.; LEE, J. H.; XHU, J. Somatic cell nuclear transfer: Past, present and future perspectives. Theriogenology, v. 68, p. S214-S231, 2007. Supplement.

CAMPBELL, K. H. S.; MCWHIR, J.; RITCHIE, W. A.; WILMUT, I. Sheep cloned by nuclear transfer from a cultured cell line. Nature, v. 380, n. 6569, p. 64-66, 1996.

CHALLIS, J. R.; THORBURN, G. D. Prenatal endocrine function and the initiation of parturition. British Medical Bulletin, v. 31, n. 1, p. 57-61, 1975.

CHALLIS, J. R. G.; MATTHEWS, S. G.; GIBB, W.; LYE, S. J. Endocrine and paracrine regulation of birth at term and preterm. Endocrine Reviews, v. 21, n. 5, p. 514-550, 2000.

CHAVATTE-PALMER, P.; HEYMAN, Y.; RICHARD, C.; MONGET, P.; LEBOURHIS, D.; KANN, G.; CHILLIARD, Y.; VIGNON, X.; RENARD, J. P. Clinical, hormonal, and hematologic characteristics of bovine calves derived from nuclei from somatic cells. Biology of Reproduction, v. 66, n. 6, p. 1596-1603, 2002.

CHAVATTE-PALMER, P.; HEYMAN, Y.; RICHARD, C.; URIEN, C.; RENARD, J. P.; SCHWARTZCORNIL, I. The immune status of bovine somatic clones. Cloning and Stem Cells, v. 11, n. 2, p. 309-318, 2009.

CHAVATTE-PALMER, P.; REMY, D.; CORDONNIER, N.; RICHARD, C.; ISSENMAN, H.; LAIGRE, P.; HEYMAN, Y.; MIALOT, J. P. Health status of cloned cattle at different ages. Cloning and Stem Cells, v. 6, n. 2, p. 94-100, 2004.

CHAVATTE-PALMER, P.; DE SOUSA, N.; LAIGRE, P.; CAMOUS, S.; PONTER, A. A.; BECKERS, J. F.; HEYMAN, Y. Ultrasound fetal measurements and pregnancy associated glycoprotein secretion in early pregnancy in cattle recipients carrying somatic clones. Theriogenology, v. 66, n. 4, p. 829-840, 2006.

CHEBEL, R. C.; DEMÉTRIO, D. G.; METZGER, J. Factors affecting success of embryo collection and transfer in large dairy herds. Theriogenology, v. 69, n. 1, p. 98-106, 2008.

CHESNÉ, P.; ADENOT, P. G.; VIGLIETTA, C.; BARATTE, M.; BOULANGER, L.; RENARD, J. P. Cloned rabbits produced by nuclear transfer from adult somatic cells. Nature Biotechnology, v. 20, n. 4, p. 366-369, 2002.

CHIAN, R. C.; NAKAHARA, H.; NIWA, K.; FUNAHASHI, H. Fertilization and early cleavage in vitro of ageing bovine oocytes after maturation in culture. Theriogenology, v. 37, n. 3, p. 665-672, 1992.

CHO, S. R.; OCK, S. A.; YOO, J. G.; MOHANA KUMAR, B.; CHOE, S. Y.; RHO, G. J. Effects of confluent, roscovitine treatment and serum starvation on the cell-cycle synchronization of bovine foetal fibroblasts.

Reproduction in Domestic Animals, v. 40, n. 2, p. 171-176, 2005.

CHORESCA JR., C. H.; KOO, O. J.; OH, H. J.; HONG, S. G.; GOMEZ, D. K.; KIM, J. H.; LEE, B. C.; PARK, S. C. Different culture conditions used for arresting the G0/G1 phase of the cell cycle in goldfish (Carassius auratus) caudal fin-derived fibroblasts. Cell Biology International, v. 33, n. 1, p. 65-70, 2009. 
CIBELLI, J. B.; STICE, S. L.; GOLUEKE, P. J.; KANE, J. J.; JERRY, J.; BLACKWELL, C.; PONCE LEON DE, F. A.; ROBL, J. M. Cloned transgenic calves produced from nonquiescent fetal fibroblasts. Science, v. 280 , n. 5367, p. 1256-1258, 1998.

CONLEY, A. J.; FORD, S. P. Effect of prostaglandin F2 alpha-induced luteolysis on in vivo and in vitro progesterone production by individual placentomes of cows. Journal of Animal Science, v. 65, n. 2, p. 500-507, 1987.

CONLEY, A. J.; MASON, J. I. Placental steroid hormones. Baillieres Clinical Endocrinology and Metabolism, v. 4, n. 2, p. 249-272, 1990.

CONSTANT, F.; GUILLOMOT, M.; HEYMAN, Y.; VIGNON, X.; LAIGRE, P.; SERVELY, J. L.; RENARD, J. P.; CHAVATTE-PALMER, P. Large offspring or large placenta syndrome? Morphometric analysis of late gestation bovine placentomes from somatic nuclear transfer pregnancies complicated by hydrallantois. Biology of Reproduction, v. 75, n. 1, p. 122-130, 2006.

DEAN, W.; BOWDEN, L.; AITCHISON, A.; KLOSE, J.; MOORE, T.; MENESES, J. J.; REIK, W.; FEIL, R. Altered imprinted gene methylation and expression in completely ES cell derived mouse fetuses: association with aberrant phenotypes. Development, v. 125, n. 12, p. 2273-2282, 1998.

DE SOUZA, P. A.; KING, T.; HARKNESS, L.; YOUNG, L. E.; WALKER, S. K.; WILMUT, I. Evaluation of gestational deficiencies in cloned sheep fetuses and placentae. Biology of Reproduction, v. 65, n. 1, p. 23-30, 2001.

EDWARDS, J. L.; SCHRICK, F. N.; MCCRACKEN, M. D.; VAN AMSTEL, S. R.; HOPKINS, F. M.; WELBORN, M. G.; DAVIES, C. J. Cloning adult farm animals: a review of the possibilities and problems associated with somatic cell nuclear transfer. American Journal of Reproductive Immunology, v. 50, n. 2, p. 113-123, 2003.

EGGAN, K.; AKUTSU, H.; LORING, J.; JACKSON-GRUSBY, L.; KLEMM, M.; RIDEOUT, W. M. $3^{\text {RD }}$; YANAGIMACHI, R.; JAENISCH, R. Hybrid vigor, fetal overgrowth, and viability of mice derived by nuclear cloning and tetraploid embryo complementation. Proceedings of the National Academy of Sciences of the USA, v. 98, n. 11, p. 6209-6214, 2001.

EGLI, D.; ROSAINS, J.; BIRKHOFF, G.; EGGAN, K. Developmental reprogramming after chromosome transfer into mitotic mouse zygotes. Nature, v. 447, n. 7145, p. 679-685, 2007.

ELEY, R. M.; THATCHER, W. W.; BAZER, F. W.; WILCOX, C. J.; BECKER, R. B.; HEAD, H. H.; ADKINSON, R. W. Development of the conceptus in the bovine. Journal of Dairy Science, v. 61, n. 4, p. 467$473,1978$.

EVERTS, R. E.; CHAVATTE-PALMER, P.; RAZZAK, A.; HUE, I.; GREEN, C. A.; OLIVEIRA, R.; VIGNON, X.; RODRIGUEZ-ZAS, S. L.; TIAN, X. C.; YANG, X.; RENARD, J. P.; LEWIN, H. A. Aberrant gene expression patterns in placentomes are associated with phenotypically normal and abnormal cattle cloned by somatic cell nuclear transfer. Physiological Genomics, v. 33, n. 1, p. 65-77, 2008.

FARIN, C. E.; FARMER, W. T.; FARIN, P. W. Pregnancy recognition and abnormal offspring syndrome in cattle. Reproduction, Fertility and Development, v. 22, n. 1, p. 75-87, 2010.

FARIN, P. W.; CROSIER, A. E.; FARIN, C. E. Influence of in vitro systems on embryo survival and fetal development in cattle. Theriogenology, v. 55, n. 1, p. 151-170, 2001.

FARIN, P. W.; FARIN, C. E. Transfer of bovine embryos produced in vivo or in vitro: survival and fetal development. Biology of Reproduction, v. 52, n. 3, p. 676-682, 1995.

FARIN, P. W.; FARIN, C. E.; MUNGAL, S. A. Measurements of bovine fetuses and placentas at 63 Days after transfer of embryos produced in vivo or in vitro. Theriogenology, v. 47, p. 319, 1997. 
FARIN, P. W.; PIEDRAHITA, J. A.; FARIN, C. E. Errors in development of fetuses and placentas from in vitro - produced bovine embryos. Theriogenology, v. 65, n. 1, p. 178-191, 2006.

FELTRIN, C.; FORELL, F.; SANTOS, L. C.; RODRIGUES, J. L. In vitro bovine embryo development after nuclear transfer by HMC using a modified WOW culture system. Reproduction, Fertility and Development, v. 18, n. 1, p. 126, 2006.

FERRELL, C. L. Maternal and fetal influences on uterine and conceptus development in the cow: I. Growth of the tissues of the gravid uterus. Journal of Animal Science, v. 69, n. 5, p. 1945-1953, 1991a.

FERRELL, C. L. Maternal and fetal influences on uterine and conceptus development in the cow: II. Blood flow and nutrient flux. Journal of Animal Science, v. 69, n. 5, p. 1954-1965, 1991b.

FERRELL, C. L. Placental regulation of fetal growth. In: CAMPION, D. R.; HAUSMAN, G. J.; MARTIN, R. J. (Ed.). Animal growth regulation. New York: Plenum Press, 1989. p. 1-19.

FERRELL, C. L.; FORD, S. P.; PRIOR, R. L.; CHRISTENSON, R. K. Blood flow, steroid secretion and nutrient uptake of the gravid bovine uterus and fetus. Journal of Animal Science, v. 56, n. 3, p. 656-667, 1983.

FERRELL, C. L.; GARRETT, W. N.; HINMAN, N. Growth, development and composition of the udder and gravid uterus of beef heifers during pregnancy. Journal of Animal Science, v. 42, n. 6, p. 1477-1489, 1976.

FISCHER-BROWN, A. E.; LINDSEY, B. R.; IRELAND, F. A.; NORTHEY, D. L.; MONSON, R. L.; CLARK, S. G.; WHEELER, M. B.; KESLER, D. J.; LANE, S. J.; WEIGEL, K. A.; RUTLEDGE, J. J. Embryonic disc development and subsequent viability of cattle embryos following culture in two media under two oxygen concentrations. Reproduction, Fertility and Development, v. 16, n. 8, p. 787-793, 2005.

FLETCHER, C. J.; ROBERTS, C. T.; HARTWICH, K. M.; WALKER, S. K.; MCMILLEN, I. C. Somatic cell nuclear transfer in the sheep induces placental defects that likely precede fetal demise. Reproduction, v. 133, $\mathrm{n}$. 1, p. 243-255, 2007.

FULKA JR., J.; FULKA, H. Somatic cell nuclear transfer (SCNT) in mammals: the cytoplast and its reprogramming activities. Advances in Experimental Medicine and Biology, v. 591, p. 93-102, 2007.

GALLI, C.; LAGUTINA, I.; CROTTI, G.; COLLEONI, S.; TURINI, P.; PONDERATO, N.; DUCHI, R.; LAZZARI, G. Pregnancy: a cloned horse born to its dam twin. Nature, v. 424, n. 6949, p. 635, 2003.

GAO, T.; ZHENG, J.; XING, F.; FANG, H.; SUN, F.; YAN, A.; GONG, X.; DING, H.; TANG, F.; SHENG, H. $Z$. Nuclear reprogramming: the strategy used in normal development is also used in somatic cell nuclear transfer and parthenogenesis. Cell Research, v. 17, n. 2, p. 135-150, 2007.

GARRY, F. B.; ADAMS, R.; MCCANN, J. P.; ODDE, K. G. Postnatal characteristics of calves produced by nuclear transfer cloning. Theriogenology, v. 45, n. 1, p. 141-152, 1996.

GEISERT, R. D.; CONLEY, A. J. Secretion and metabolism of steroids in subprimate mammals during pregnancy. In: BAZER, F. W. (Ed.). The endocrinology of pregnancy. New Jersey: Humana Press Inc., 1998. p. 291-318.

GERGER, R. P. C.; RIBEIRO. E. S.; FORELL, F.; BERTOLINI, L. R.; RODRIGUES, J. L.; AMBROSIO, C. E.; MIGLINO, M. A.; MEZZALIRA, A.; BERTOLINI, M. In vitro development of bovine cloned embryos produced by handmade cloning (hmc) using somatic cells from distinct cell culture confluences. Genetics and Molcular Research, v. 9, n. 1, p. 295-302, 2010.

GIBBONS, J.; ARAT, S.; RZUCIDLO, J.; MIYOSHI, K.; WALTENBURG, R.; RESPESS, D.; VENABLE, A.; STICE, S. Enhanced survivability of cloned calves derived from roscovitine-treated adult somatic cells. Biology of Reproduction, v. 66, n. 4, p. 895-900, 2002. 
GLUCKMAN, P. D.; MOREL, P. C. H.; AMBLER, G. R.; BREIER, B. H.; BLAIR, H. T.; MCCUTCHEON, S. N. Elevating maternal insulin-like growth factor-I in mice and rats alters the pattern of fetal growth by removing maternal constraint. The Journal of Endocrinology, v. 134, n. 1, p. R1-R3, 1992.

GODFREY, K. M. Maternal regulation of fetal development and health in adult life. European Journal of Obstetrics, Gynecology, and Reproductive Biology, v. 78, n. 2, p. 141-150, 1998.

GOISSIS, M. D.; CAETANO, H. V.; MARQUES, M. G.; DE BARROS, F. R.; FEITOSA, W. B.; MILAZZOTTO, M. P.; BINELLI, M.; ASSUMPÇÃO, M. E.; VISINTIN, J. A. Effects of serum deprivation and cycloheximide on cell cycle of low and high passage porcine fetal fibroblasts. Reproduction in Domestic Animals, v. 42, n. 6, p. 660-663, 2007.

GONÇALVES, P. B. D.; FIGUEIREDO, J. R.; FREITAS, V. J. F. Biotécnicas aplicadas à reprodução animal. 2. ed. São Paulo: Roca, 2008. 395 p.

GOODWIN, R. F. W. Division of the common mammals into two groups according to the concentration of fructose in the blood of the fetus. The Journal of Physiology, v. 132, n. 1, p. 146-156, 1956.

GUILLOMOT, M.; FLÉCHON, J. E.; LEROY, F. Blastocyst development and implantation. In: THIBAULT C.; LEVASSEUR, M. C.; HUNTER, R. H. F. Reproduction in mammals and man. Paris: Ellipses, 1993. p. 387 411.

HAIG, D.; GRAHAM, C. Genomic imprinting and the strange case of the insulin-like growth factor II receptor. Cell, v. 64, n. 6, p. 1045-1046, 1991.

HANSEN, P. J.; BLOCK, J.; LOUREIRO, B.; BONILLA, L.; HENDRICKS, K. E. Effects of gamete source and culture conditions on the competence of in vitro-produced embryos for post-transfer survival in cattle.

Reproduction, Fertility and Development, v. 22, n. 1, p. 59-66, 2010.

HASHEM, M. A.; BHANDARI, D. P.; KANG, S. K.; LEE, B. C.; SUK, H. W. Cell cycle analysis of in vitro cultured goral (Naemorhedus caudatus) adult skin fibroblasts. Cell Biology International, v. 30, n. 9, p. 698$703,2006$.

HASHIZUME, K.; ISHIWATA, H.; KIZAKI, K.; YAMADA, O.; TAKAHASHI, T.; IMAI, K.; PATEL, O. V.; AKAGI, S.; SHIMIZU, M.; TAKAHASHI, S.; KATSUMA, S.; SHIOJIMA, S.; HIRASAWA, A.; TSUJIMOTO, G.; TODOROKI, J.; IZAIKE, Y. Implantation and placental development in somatic cell clone recipient cows. Cloning and Stem Cells, v. 4, n. 3, p. 197-209, 2002.

HASLER, J. F. Current status and potential of embryo transfer and reproductive technology in dairy cattle. Journal of Dairy Science, v. 75, n. 10, p. 2857-2879, 1992.

HASLER, J. F.; HENDERSON, W. B.; HURTGEN, P. J.; JIN, Z. Q.; MCCAULEY, A. D.; MOWER, S. A.; NEELY, B.; SHUEY, L. S.; STOKES, J. E.; TRIMMER, S. A. Production, freezing and transfer of bovine IVF embryos and subsequent calving results. Theriogenology, v. 43, n. 1, p. 141-152, 1995.

HAY, W. W. Regulation of placental metabolism by glucose supply. Reproduction, Fertility and Development, v. 7, n. 3, p. 365-375, 1995.

HAYES, O.; RAMOS, B.; RODRÍGUEZ, L. L.; AGUILAR, A.; BADÍA, T.; CASTRO, F. O. Cell confluency is as efficient as serum starvation for inducing arrest in the G0/G1 phase of the cell cycle in granulosa and fibroblast cells of cattle. Animal Reproduction Science, v. 87, n. 3-4, p. 181-192, 2005.

HEYMAN, Y.; CHAVATTE-PALMER, P.; LEBOURHIS, D.; CAMOUS, S.; VIGNON, X.; RENARD, J. P. Frequency and occurrence of late-gestation losses from cattle cloned embryos. Biology of Reproduction, v. 66, n. 1, p. 6-13, 2002.

HILL, J. R.; CHAVATTE-PALMER, P. Pregnancy and neonatal care of cloned animals. In: CIBELLI, J.; 
LANZA R. P.; CAMPBELL, K. H. S.; WEST, M. D. (Ed.). Principles of Cloning. San Diego: Academic Press, 2002. p. 247-266.

HILL, J. R.; EDWARDS, J. F.; SAWYER, N.; BLACKWELL, C.; CIBELLI, J. B. Placental anomalies in a viable cloned calf. Cloning, v. 3, n. 2, p. 83-88, 2001.

HILL, J. R.; ROUSSEL, A. J.; CIBELLI, J. B.; EDWARDS, J. F.; HOOPER, N. L.; MILLER, N. W.; THOMPSON, J. A.; LOONEY, C. R.; WESTHUSIN, M. E.; ROBL, J. M.; STICE, S. L. Clinical and pathologic features of cloned transgenic calves and fetuses (13 case studies). Theriogenology, v. 51, n. 8, p. 1451-1465, 1999.

HILL, R.; BURGHARDT, R. C.; JONES, K.; LONG, C. R.; LOONEY, C.; SHIN, T.; SPENCER, T. E.; THOMPSON, J. A.; WINGER, Q. A.; WESTHUSIN, M. E. Evidence for placental abnormality as the major cause of mortality in first-trimester somatic cell cloned bovine fetuses. Biology of Reproduction, v. 63, n. 6, p. $1787-1794,2000$.

HOLM, P.; BOOTH, P. J.; SCHMIDT, M. H.; GREVE, T.; CALLESEN, H. High bovine blastocyst development in a static in vitro production system using SOFaa medium supplemented with sodium citrate and myo-inositol with or without serum-proteins. Theriogenology, v. 52, n. 4, p. 683-700, 1999.

HUMPHERYS, D.; EGGAN, K.; AKUTSU, H.; FRIEDMAN, A.; HOCHEDLINGER, K.; YANAGIMACHI, R.; LANDER, E. S.; GOLUB, T. R.; JAENISCH, R. Abnormal gene expression in cloned mice derived from embryonic stem cell and cumulus cell nuclei. Proceedings of the National Academy of Sciences of the USA, v. 99, n. 20 , p. $12889-12894,2002$.

HUSZAR, G. B.; WALSH, M. P. Relationship between myometrial and cervical functions in pregnancy and labor. Seminars in Perinatology, v. 15, n. 2, p. 97-117, 1991.

INOUE, K.; OGONUKI, N.; MOCHIDA, K.; YAMAMOTO, Y.; TAKANO, K.; KOHDA, T.; ISHINO, F.; OGURA, A. Effects of donor cell type and genotype on the efficiency of mouse somatic cell cloning. Biology of Reproduction, v. 69 n. 4, p. 1394-1400, 2003.

JENKIN, G.; YOUNG, I. R. Mechanisms responsible for parturition; the use of experimental models. Animal Reproduction Science, v. 82-83, p. 567-581, 2004. Review.

JOHN, R. M.; SURANI, M. A. Genomic imprinting, mammalian evolution, and the mystery of egg-laying mammals. Cell, v. 101, n. 6, p. 585-588, 2000.

JUNQUEIRA, L. C.; CARNEIRO, J. Histologia básica. 10. ed. Rio de Janeiro: Guanabara Koogan, 2004. 448 p.

KANG, Y. K.; KOO, D. B.; PARK, J. S.; CHOI, Y. H.; CHUNG, A. S.; LEE, K. K.; HAN, Y. M. Aberrant methylation of donor genome in cloned bovine embryos. Nature Genetics, v. 28, n. 2, p. 173-177, 2001.

KATO, Y.; TANI, T.; SOTOMARU, Y.; KUROKAWA, K.; KATO, J.; DOGUCHI, H.; YASUE, H.; TSUNODA, Y. Eight calves cloned from somatic cells of a single adult. Science, v. 282, n. 5396, p. 2095-2098, 1998.

KATO, Y.; TANI, T.; TSUNODA, Y. Cloning of calves from various somatic cell types of male and female adult, newborn and fetal cows. Journal of Reproduction and Fertility, v. 120, n. 2, p. 231-237, 2000.

KIM, M. K.; JANG, G.; OH, H. J.; YUDA, F.; KIM, H. J.; HWANG, W. S.; HOSSEIN, M. S.; KIM, J. J.; SHIN, N. S.; KANG, S. K.; LEE, B. C. Endangered wolves cloned from adult somatic cells. Cloning and Stem Cells, v. 9, n. 1, p. 130-137, 2007.

KOO, O. J.; HOSSEIN, M. S.; HONG, S. G.; MARTINEZ-CONEJERO, J. A.; LEE, B. C. Cell cycle synchronization of canine ear fibroblasts for somatic cell nuclear transfer. Zygote, v. 17, n. 1, p. 37-43, 2009. 
KREBS, C.; LONGO, L. D.; LEISER, R. Term ovine placental vasculature: comparison of sea level and high altitude conditions by corrosion cast and histomorphometry. Placenta, v. 18, n. 1, p. 43-51, 1997.

KRUIP, T. A.; DEN DAAS, J. H. G. In vitro produced and cloned embryos: effects on pregnancy, parturition and offspring. Theriogenology, v. 47, n. 1, p. 43-52, 1997.

KUBO, M. Pathology of diseases in calves cloned by nuclear transfer. Cloning and Stem Cells, v. 4, p. 281, 2002.

KUBOTA, C.; YAMAKUCHI, H.; TODOROKI, J.; MIZOSHITA, K.; TABARA, N.; BARBER, M.; YANG, $\mathrm{X}$. Six cloned calves produced from adult fibroblast cells after long-term culture. Proceedings of the National Academy of Sciences of the USA, v. 97, n. 3, p. 990-995, 2000.

KUES, W. A.; ANGER, M.; CARNWATH, J. W.; PAUL, D.; MOTLIK, J.; NIEMANN, H. Cell cycle synchronization of porcine fetal fibroblasts: effects of serum deprivation and reversible cell cycle inhibitors. Biology of Reproduction, v. 62, n. 2, p. 412-419, 2000.

KUROSAKA, S.; NAGAO, Y.; MINAMI, N.; YAMADA, M.; IMAI, H. Dependence of DNA synthesis and in vitro development of bovine nuclear transfer embryos on the stage of the cell cycle of donor cells and recipient cytoplasts. Biology of Reproduction, v. 67, n. 2, p. 643-647, 2002.

LANZA, R. P.; CIBELLI, J. B.; DIAZ, F.; MORAES, C. T.; FARIN, P. W.; FARIN, C. E.; HAMMER, C. J.; WEST, M. D.; DAMIANI, P. Cloning of an endangered species (Bos gaurus) using interspecies nuclear transfer. Cloning, v. 2, n. 2, p. 79-90, 2000.

LAZZARI, G.; WRENZYCKI, C.; HERRMANN, D.; DUCHI, R.; KRUIP, T.; NIEMANN, H.; GALLI, C. Cellular and molecular deviations in bovine in vitro-produced embryos are related to the large offspring syndrome. Biology of Reproduction, v. 67, n. 3, p. 767-775, 2002.

LEE, B. C.; KIM, M. K.; JANG, G.; OH, H. J.; YUDA, F.; KIM, H. J.; HOSSEIN, M. S.; KIM, J. J.; KANG, S. K.; SCHATTEN, G.; HWANG, W. S. Dogs cloned from adult somatic cells. Nature, v. 436, n. 7051, p. 641, 2005.

LEE, K. Y.; HUANG, H.; JU, B.; YANG, Z.; LIN, S. Cloned zebrafish by nuclear transfer from long-termcultured cells. Nature Biotechnology, v. 20, n. 8, p. 795-799, 2002.

LEE, R. S.; PETERSON, A. J.; DONNISON, M. J.; RAVELICH, S.; LEDGARD, A. M.; LI, N.; OLIVER, J. E.; MILLER, A. L.; TUCKER, F. C.; BREIER, B.; WELLS, D. N. Cloned cattle fetuses with the same nuclear genetics are more variable than contemporary half-siblings resulting from artificial insemination and exhibit fetal and placental growth deregulation even in the first trimester. Biology of Reproduction, v. 70, n. 1, p. 1-11, 2004.

LEISER, R.; KAUFMANN, P. Placental structure: in a comparative aspect. Experimental and Clinical Endocrinology, v. 102, n. 3, p. 122-134, 1994.

LI, J.; VAJTA, G.; CALLESEN, H. Comparison of cell numbers of zona-intact and zona-free parthenogenetically activated porcine embryos cultured in vitro. Reproduction, Fertility and Development, v. 22, n. 1, p. 234, 2010.

LI, N.; WELLS, D. N.; PETERSON, A. J.; LEE, R. S. Perturbations in the biochemical composition of fetal fluids are apparent in surviving bovine somatic cell nuclear transfer pregnancies in the first half of gestation. Biology of Reproduction, v. 73, n. 1, p. 139-148, 2005.

LI, Z.; SUN, X.; CHEN, J.; LIU, X.; WISELY, S. M.; ZHOU, Q.; RENARD, J. P.; LENO, G. H.; ENGELHARDT, J. F. Cloned ferrets produced by somatic cell nuclear transfer. Developmental Biology, v. 293, n. 2, p. 439-448, 2006. 
LOI, P.; PTAK, G.; BARBONI, B.; FULKA, J. J. R.; CAPPAI, P.; CLINTON, M. Genetic rescue of an endangered mammal by cross-species nuclear transfer using post-mortem somatic cells. Nature Biotechnology, v. 19 , n. 10 , p. $962-964,2001$.

LIU, C. T.; YU, K. C.; JU, J. C. Cell cycle stage analysis of rabbit foetal fibroblasts and cumulus cells. Reproduction in Domestic Animals, v. 39, n. 6, p. 385-390, 2004.

LU, K. H.; GORDON, I.; GALLAGHER, M.; MCGOVERN, H. Birth of twins after transfer of cattle embryos produced by in vitro techniques. The Veterinary Record, v. 122, n. 22, p. 539-540, 1988.

MCEVOY, T. G.; ROBINSON, J. J.; AITKEN, R. P.; FINDLAY, P. A.; ROBERSTON, I. S. Dietary excesses of urea influence the viability and metabolism of preimplantation sheep embryos and may affect fetal growth among survivors. Animal Reproduction Science, v. 47, n. 1-2, p. 71-90, 1997.

MCMILLEN, C. I.; ROBINSON, J. S. Developmental origins of the metabolic syndrome: prediction, plasticity, and programming. Physiological Reviews, v. 85, n. 2, p. 571-633, 2005.

MEIRELLES, F. V.; BIRGEL, E. H.; PERECIN, F.; BERTOLINI, M.; TRALDI, A. S.; PIMENTEL, J. R.; KOMNINOU, E. R.; SANGALLI, J. R.; NETO, P. F.; NUNES, M. T.; POGLIANI, F. C.; MEIRELLES, F. D.; KUBRUSLY, F. S.; VANNUCCHI, C. I.; SILVA, L. C. Delivery of cloned offspring: experience in Zebu cattle (Bos indicus). Reproduction, Fertility and Development, v. 22, n. 1, p. 88-97, 2010.

MEZNARICH, H. K.; HAY JR., W. W.; SPARKS, J. W.; MESCHIA, G.; BATTAGLIA, F. C. Fructose disposal and oxidation rates in the ovine fetus. Quarterly Journal of Experimental Physiology, v. 72, n. 4, p. 617-625, 1987.

MEZZALIRA, J. C. Efeito da heteroplasmia na densidade celular e desenvolvimento embrionário in vitro de embriões bovinos clonados por transferência nuclear de célula somática. 2009. 77 f. Dissertação (Mestrado em Ciência Animal) - Centro de Ciências Agroveterinárias, Universidade do Estado de Santa Catarina, Santa Catarina, 2009.

MIGLINO, M. A. Pesquisa anatômica sobre a ramificação e distribuição das artérias e veias da placenta de bovinos. 1991. 303 f. Tese (Livre Docência) - Faculdade de Medicina Veterinária e Zootecnia, Universidade de São Paulo, São Paulo, 1991.

MIGLINO, M. A.; PEREIRA, F. T. V.; VISINTIN, J. A.; GARCIA, J. M.; MEIRELLES, F. V.; RUMPF, R.; AMBRÓSIO, C. E.; PAPA, P. C.; SANTOS, T. C.; CARVALHO, A. F.; LEISER, R.; CARTER, A. M. Placentation in cloned cattle: structure and microvascular architecture. Theriogenology, v. 68, n. 4, p. 604-617, 2007.

MILES, J. R.; FARIN, C. E.; RODRIGUEZ, K. F.; ALEXANDER, J. E.; FARIN, P. W. Angiogenesis and morphometry of bovine placentas in late gestation from embryos produced in vivo or in vitro. Biology of Reproduction, v. 71, n. 6, p. 1919-1926, 2004.

MISICA-TURNER, P. M.; OBACK, F. C.; EICHENLAUB, M.; WELLS, D. N.; OBACK, B. Aggregating embryonic but not somatic nuclear transfer embryos increases cloning efficiency in cattle. Biology of Reproduction, v. 76, n. 2, p. 268-278, 2007.

MOORE, T. Genetic conflict, genomic imprinting and establishment of the epigenotype in relation to growth. Reproduction, v. 122, n. 2, p. 185-193, 2001.

MOORE, T.; HAIG, D. Genomic imprinting in mammalian development: a parental tug-of-war. Trends in Genetics, v. 7, n. 2, p. 45-49, 1991.

MOSSMAN, H. W. Eutheria or anostraca. In: University Press, 1987. p. 63-114. Vertebrate fetal membranes. New Brunswick: Rutgers 
NIEMANN, H.; WRENZYCKI, C. Alterations of expression of developmentally important genes in preimplantation bovine embryos by in vitro culture conditions: implications for subsequent development. Theriogenology, v. 53, n. 1, p. 21-34, 2000.

NIXON, D. A. The transplacental passage of fructose, urea and meso-inositol in the direction from foetus to mother, as demonstrated by perfusion studies in the sheep. Journal of Physiology, v. 166, n. 2, p. 351-362, 1963.

OBACK, B. Climbing Mount Efficiency-small steps, not giant leaps towards higher cloning success in farm animals. Reproduction in Domestic Animals, v. 43, p. 407-416, 2008. Supplementum 2.

PALMA, G. A.; SINOWATZ, F. Male and female effects on the in vitro production of bovine embryos. Anatomia, Histologia e Embryologia, v. 33, n. 5, p. 257-262, 2004.

PALMIERI, C.; LOI, P.; REYNOLDS, L. P.; PTAK, G.; DELLA SALDA, L. Placental abnormalities in ovine somatic cell clones at term: a light and electron microscopic investigation. Placenta, v. 28, n. 5-6, p. 577-584, 2007.

PANARACE, M.; AGÜERO, J. I.; GARROTE, M.; JAUREGUI, G.; SEGOVIA, A.; CANÉ, L.; GUTIÉRREZ, J.; MARFIL, M.; RIGALI, F.; PUGLIESE, M.; YOUNG, S.; LAGIOIA, J.; GARNIL, C.; FORTE PONTES, J. E.; ERENO JUNIO, J. C.; MOWER, S.; MEDINA, M. How healthy are clones and their progeny: 5 years of field experience. Theriogenology, v. 67, n. 1, p. 142-151, 2007.

PARK, Y. S.; KIM, S. S.; KIM, J. M.; PARK, H. D.; BYUN, M. D. The effects of duration of in vitro maturation of bovine oocytes on subsequent development, quality and transfer of embryos. Theriogenology, v. 64, n. 1, p. 123-134, 2005.

PARRISH, J. J.; SUSKO-PARRISH, J.; WINER, M. A.; FIRST, N. L. Capacitation of bovine sperm by heparin. Biology of Reproduction, v. 38, n. 5, p. 1171-1180, 1988.

PEDERSEN, H. G.; SCHMIDT, M.; SANGILD, P. T.; STRØBECH, L.; VAJTA, G.; CALLESEN, H.; GREVE, T. Clinical experience with embryos produced by handmade cloning: work in progress. Molecular and Cellular Endocrinology, v. 234, n. 1-2, p. 137-143, 2005.

PEIXOTO, M. G. C. D.; BERGMANN, J. A. G.; FONSECA, C. G.; PENNA, V. M.; PEREIRA, C. S. Effects of environmental factors on multiple ovulation of zebu donors. Arquivo Brasileiro de Medicina Veterinária e Zootecnia, v. 58, p. 567-574, 2006.

PENNINGA, L.; LONGO, L. D. Ovine placentome morphology: effects of high altitude, long-term hypoxia. Placenta, v. 19, n. 2-3, p. 187-193, 1998.

PERRY, J. S. The mammalian fetal membranes. Journal of Reproduction and Fertility, v. 62, n. 2, p. 321-335, 1981.

PERRY, V. E. A.; NORMAN, S. T.; OWEN, J. A.; DANIEL, R. C. W.; PHILLIPS, N. Low dietary protein during early pregnancy alters bovine placental development. Animal Reproduction Science, v. 55, n. 1, p. 1321, 1999.

PEURA, T. T.; LEWIS, I. M.; TROUNSON, A. O. The effect of recipient oocyte volume on nuclear transfer in cattle. Molecular Reprodroduction and Development, v. 50, n. 2, p. 185-191, 1998.

PIETERSE, M. C.; KAPPEN, K. A.; KRUIP, T. A.; TAVERNE, M. A. Aspiration of bovine oocytes during transvaginal ultrasound scanning of the ovaries. Theriogenology, v. 30, n. 4, p. 751-762, 1988.

POLEJAEVA, I. A.; CHEN, S. H.; VAUGHT, T. D.; PAGE, R. L.; MULLINS, J.; BALL, S.; DAL, Y.; BOONE, J.; WALKER, S.; AYARES, D. L.; COLMAN, A.; CAMPBELL, K. H. S. Cloned pigs produced by nuclear transfer from adult somatic cells. Nature, v. 407, n. 6800, p. 86-90, 2000. 
PONTES, J. H.; NONATO-JUNIOR, I.; SANCHES, B. V.; ERENO-JUNIOR, J. C.; UVO, S.; BARREIROS, T. R.; OLIVEIRA, J. A.; HASLER, J. F.; SENEDA, M. M. Comparison of embryo yield and pregnancy rate between in vivo and in vitro methods in the same Nelore (Bos indicus) donor cows. Theriogenology, v. 71 n. 4, p. 690-697, 2009.

POWELL, A. M.; TALBOT, N. C.; WELLS, K. D.; KERR, D. E.; PURSEL, V. G.; WALL, R. J. Cell donor influences success of producing cattle by somatic cell nuclear transfer. Biology of Reproduction, v. 71, n. 1, p. 210-216, 2004.

PRIOR, R. L.; LASTER, D. B. Development of the bovine fetus. Journal of Animal Science, v. 48, n. 6, p. 1546-1553, 1979.

RENARD, J. P.; CHASTANT, S.; CHESNE, P.; RICHARD, C.; MARCHAL, J.; CORDONNIER, N.; CHAVATTE, P.; VIGNON, X. Lymphoid hypoplasia and somatic cloning. Lancet, v. 353, n. 9163, p. 1489$1491,1999$.

REYNOLDS, L. P.; MILLAWAY, D. S.; KIRSCH, J. D.; INFELD, J. E.; REDMER, D. A. Growth and in vitro metabolism of placental tissues of cows from day 100 to day 250 of gestation. Journal of Reproduction and Fertility, v. 89, n. 1, p. 213-222, 1990.

RIBEIRO, E. S.; GERGER, R. P. C.; OHLWEILER, L. U.; ORTIGARI JR, I.; MEZZALIRA, J. C.; FORELL, F.; BERTOLINI, L. R.; RODRIGUES, J. L.; AMBROSIO, C. E.; MIGLINO, M. A.; MEZZALIRA, A.; BERTOLINI, M. Developmental potential of bovine handmade cloned embryos reconstructed by aggregation or fusion with distinct cytoplasmic volumes. Cloning and Stem Cells, v. 11, n. 3, p. 377-386, 2009.

RIDEOUT, W. M.; WAKAYAMA, T.; WUTZ, A.; EGGAN, K.; JACKSON-GRUSBY, L.; DAUSMAN, J.; YANAGIMACHI, R.; JAENISCH, R. Generation of mice from wild-type and targeted ES cells by nuclear cloning. Nature Genetics, v. 24, n. 2, p. 109-110, 2000.

ROBL, J. M.; STICE, S. L. Prospects for the commercial cloning of animals by nuclear transplantation. Theriogenology, v. 31, n. 1, p. 75-84, 1989.

RUDENKO, L.; MATHESON, J. C.; ADAMS, A. L.; DUBBIN, E. S.; GREENLEES, K. J. Food consumption risks associated with animal clones: what should be investigated? Cloning and Stem Cells, v. 6, n. 2, p. 79-93, 2004.

SAKAI, R. R.; TAMASHIRO, K. L. K.; YAMAZAKI, Y.; YANAGIMACHI, R. Cloning and assisted reproductive techniques: influence on early development and adult phenotype. Birth Defects Research, v. 75, n. 2, p. 151-162, 2005. Part C.

SCHLAFER, D. H.; FISHER, P. J.; DAVIES, C. J. The bovine placenta before and after birth: placental development and function in health and disease. Animal Reproduction Science, v. 60-61, p. 145-160, 2000.

SCHURMANN, A.; WELLS, D. N.; OBACK, B. Early zygotes are suitable recipients for bovine somatic nuclear transfer and result in cloned offspring. Reproduction, v. 132, n. 6, p. 839-848, 2006.

SENEDA, M. M.; ESPER, C. R.; GARCIA, J. M.; ANDRADE, E. R.; BINELLI, M.; OLIVEIRA, J. A.; NASCIMENTO, A. B. Efficacy of linear and convex transducers for ultrasound - guided transvaginal follicle aspiration. Theriogenology, v. 59, n. 5-6, p. 1435-1440, 2003.

SENGER, P. L. Pathways to pregnancy and parturition. 2. ed. Washington: Pullman, 2003. 373 p.

SHIN, T.; KRAEMER, D.; PRYOR, J.; LIU, L.; RUGILA, J.; HOWE, L.; BUCK, S.; MURPHY, K.; LYONS, L.; WESTHUSIN, M. A cat cloned by nuclear transplantation. Nature, v. 415, n. 6874, p. 859, 2002.

SLOSS, V.; DUFTY, J. H. Handbook of bovine obstetrics. In: Pregnancy and gestation. Baltimore: Williams \& Wilkins Co., 1980. p. 30-44. 
SMITH, L. C. Membrane and intracellular effects of ultraviolet irradiation with Hoechst33342 on bovine secondary oocytes matured in vitro. Journal of Reproduction and Fertility, v. 99, n. 1, p. 39-44, 1993.

SPRITZE, A.; EGITO, A. A.; MARIANTE, A. S.; MCMANUS, C. Caracterização genética da raça bovina Crioulo Lageano por marcadores moleculares RAPD. Pesquisa Agropecuaria Brasileira, v. 38, p. 1157-1164, 2003.

STICE, S. L.; STRELCHENKO, N. S.; KEEFER, C. L.; MATTHEWS, L. Pluripotent bovine embryonic cell lines direct embryonic development following nuclear transfer. Biology of Reproduction, v. 54, n. 1, p. 100$110,1996$.

STRINGFELLOW, D. A.; SEIDEL, S. M. Manual of International Embryo Transfer Society (IETS). 3. ed. Illinois: International Embryo Transfer Society, INC., 1998. 173 p.

SUN, Y. H.; CHEN, S. P.; WANG, Y. P.; HU, W.; ZHU, Z. Y. Cytoplasmic impact on cross-genus cloned fish derived from transgenic common carp (Cyprinus carpio) nuclei and goldfish (Carassius auratus) enucleated eggs. Biology of Reproduction, v. 72, p. 510-515, 2005.

SUN, X.; WANG, S.; ZHANG, Y.; WANG, H.; WANG, L.; YING, L.; LI, R.; LI, N. Cell-cycle synchronization of fibroblasts derived from transgenic cloned cattle ear skin: effects of serum starvation, roscovitine and contact inhibition. Zygote, v. 16, n. 2, p. 111-116, 2008.

TAYLOR, K. A. C. C. A colorimetric fructose assay. Applied Biochemistry and Biotechnology, v. 53, p. 215$227,1995$.

TECIRLIOGLU, R. T.; COONEY, M. A.; LEWIS, I. M.; KORFIATIS, N. A.; HODGSON, R.; RUDDOCK, N. T.; VAJTA, G.; DOWNIE, S.; TROUNSON, A. O.; HOLLAND, M. K.; FRENCH, A. J. Comparison of two approaches to nuclear transfer in the bovine: hand-made cloning with modifications and the conventional nuclear transfer technique. Reproduction, Fertility and Development, v. 17, n. 5, p. 573-585, 2005.

TEISSIÉ, J.; EYNARD, N.; GABRIEL, B.; ROLS, M. P. Electropermeabilization of cell membranes. Advanced Drug Delivery Reviews, v. 35, n. 1, p. 3-19, 1999.

TSUNODA, Y.; SHIODA, Y.; ONODERA, M.; NAKAMURA, K.; UCHIDA, T. Differential sensitivity of mouse pronuclei and zygote cytoplasm to Hoechst staining and ultraviolet irradiation. Journal of Reproduction and Fertility, v. 82, n. 1, p. 173-178, 1988.

VAJTA, G.; HOLM, P.; GREVE, T.; CALLESEN, H. The Submarine Incubation System, a new tool for in vitro embryo culture. A technique report. Theriogenology, v. 48, p. 1379-1385, 1997.

VAJTA, G.; KRUGH, P. M.; MTANGO, N. R.; CALLESEN, H. Hand-made cloning approach: potentials and limitations. Reproduction, Fertility and Development, v. 17, n. 1-2, p. 97-112, 2005.

VAJTA, G.; LEWIS, I. M.; HYTTEL, P.; THOUAS, G. A.; TROUNSON, A. O. Somatic cell cloning without micromanipulators. Cloning, v. 3, n. 2, p. 89-95, 2001.

VAJTA, G.; LEWIS, I. M.; KORTIATIS, N. A.; TRAVERS, R. L.; TROUNSON, A. O. Bovine somatic cell cloning without micromanipulators: optimization of certain parameters. Reproduction, Fertility and Development, v. 57, n. 1, p. 453, 2002.

VAJTA, G.; LEWIS, I. M.; TROUNSON, A. O.; PURUP, S.; MADDOX-HYTTEL, P.; SCHMIDT, M.; PEDERSEN, H. G.; GREVE, T.; CALLESEN, H. Handmade somatic cell cloning in cattle: analysis of factors contributing the high efficiency in vitro. Biology of Reproduction, v. 68, n. 2, p. 571-578, 2003.

VAJTA, G.; PEURA, T. T.; HOLM, P.; PÁlDI, A.; GREVE, T.; TROUNSON, A. O.; CALLESEN, H. A new method for culture of zona-included or zona-free embryos: the Well of the Well (WOW) system. Molecular Reproduction and Development, v. 55, n. 3, p. 256-264, 2000. 
VAJTA, G.; ZHANG, Y.; MACHÁTY, Z. Somatic cell nuclear transfer in pigs: recent achievements and future possibilities. Reproduction, Fertility and Development, v. 19, n. 2, p. 403-423, 2007.

VAN WAGTENDONK-DE LEEUW, A. M.; AERTS, B. J.; DEN DAAS, J. H. Abnormal offspring following in vitro production of bovine preimplantation embryos: a field study. Theriogenology, v. 49, n. 5, p. 883-894, 1998.

VARAGO, F. C.; MENDONÇA, L. F.; LAGARES, M. A. Produção in vitro de embriões bovinos: estado da arte e perspectiva de uma técnica em constante evolução. Revista Brasileira de Reprodução Animal, v. 32, n. 2, p. 100-109, 2008.

VIUFF, D.; PALSGAARD, A.; RICKORDS, L.; LAWSON, L. G.; GREVE, T.; SCHMIDT, M.; AVERY, B.; HYTTEL, P.; THOMSEN, P. D. Bovine embryos contain a higher proportion of polyploidy cells in the trophectoderm than in the embryonic disc. Molecular Reproduction and Development, v. 62, n. 4, p. 483-488. 2002

WAKAYAMA, T.; PERRY, A. C. F.; ZUCCOTTI, M.; JOHNSON, K. R.; YANAGIMACHI, R. Full-term development of mice from enucleated oocytes injected with cumulus cell nuclei. Nature, v. 394, n. 6691, p. 369374, 1998.

WAKISAKA-SAITO, N.; KOHDA, T.; INOUE, K.; OGONUKI, N.; MIKI, H.; HIKICHI, T.; MIZUTANI, E.; WAKAYAMA, T.; KANEKO-ISHINO, T.; OGURA, A.; ISHINO, F. Chorioallantoic placenta defects in cloned mice. Biochemical and Biophysical Research Communications, v. 349, n. 1, p. 106-114, 2006.

WALKER, S. K.; HARTWICH, K. M.; SEAMARK, R. F. The production of unusually large offspring following embryo manipulation: concepts and challenges. Theriogenology, v. 45, n. 1, p. 111-120, 1996.

WELLS, D. N.; FORSYTH, J. T.; MCMILLAN, V.; OBACK, B. The health of somatic cell cloned cattle and their offspring. Cloning and Stem Cells, v. 6, n. 2, p. 101-110, 2004.

WELLS, D. N.; MISICA, P. M.; TERVIT, H. R. Production of cloned calves following nuclear transfer with cultured adult mural granulosa cells. Biology of Reproduction, v. 60, n. 4, p. 996-1005, 1999.

WILLADSEN, S. M. Nuclear transplantation in sheep embryos. Nature, v. 320, n. 6057, p. 63-65, 1986.

WILLADSEN, S. M.; JANZEN, R. E.; MCALISTER, R. J.; SHEA, B. F.; HAMILTON, G.; MCDERMAND, D. The viability of late morulae and blastocysts produced by nuclear transplantation in cattle. Theriogenology, v. 35, n. 1, p. 161-170, 1991.

WILMUT, I.; SCHNIEKE, A. E.; MCWHIR, J.; KIND, A. J.; CAMPBELL, K. H. S. Viable offspring derived from fetal and adult mammalian cells. Nature, v. 385, n. 6619, p. 810-813, 1997.

WILSON, J. M.; WILLIAMS, J. D.; BONDIOLI, K. R.; LOONEY, C. R.; WESTHUSIN, M. E.; MCCALLA, D. F. Comparison of birth weight and growth characteristics of bovine calves produced by nuclear transfer (cloning), embryo transfer and natural mating. Animal Reproduction Science, v. 38, p. 73-83, 1995.

WINTOUR, E. M.; LAURENCE, B. M.; LINGWOOD, B. E. Anatomy, physiology and pathology of the amniotic and allantoic compartments. Australian Veterinarian Journal, v. 63, n. 7, p. 216-221, 1986.

WOODING, F. B. P. Role of binucleate cells in fetomaternal cell fusion at implantation in the sheep. The American Journal of Anatomy, v. 170, n. 2, p. 233-250, 1984.

WOODING, F. B. P. Structure and function of placental binucleate ('giant') cells. Bibliotheca Anatômica, v. 22, p. 134-139, 1982.

WOODING, F. B. P.; WATHES, D. C. Binucleate cell migration in the bovine placentome. Journal of Reproduction and Fertility, v. 59, n. 2, p. 425-430, 1980. 
WOODS, G. L.; WHITE, K. L.; VANDERWALL, D. K.; LI, G. P.; ASTON, K. I.; BUNCH, T. D.; MEERDO, L. N.; PATE, B. J. A mule cloned from fetal cells by nuclear transfer. Science, v. 301, n. 5636, p. 1063, 2003.

WRENZYCKI, C.; HERRMANN, D.; CARWATH, J. W.; NIEMANN, H. Alterations in the relative abundance of gene transcripts in preimplantation bovine embryos cultured in medium supplemented with either serum or PVA. Molecular Reproduction and Development, v. 53, n. 1, p. 8-18, 1999.

WRENZYCKI, C.; HERRMANN, D.; CARWATH, J. W.; NIEMANN, H. Expression of RNA from developmentally important genes in preimplantation bovine embryos produced in TCM supplemented with BSA. Journal of Reproduction and Fertility, v. 112, n. 2, p. 387-398, 1998.

WRENZYCKI, C.; WELLS, D.; HERRMANN, D.; MILLER, A.; OLIVER, J.; TERVIT, R.; NIEMANN, H. Nuclear transfer protocol affects messenger RNA expression patterns in cloned bovine blastocysts. Biology of Reproduction, v. 65, n. 1, p. 309-317, 2001.

XUE, F.; CINDY TIAN, C.; DU, F.; KUBOTA, C.; TANEJA, M.; DINNYES, A.; DAI, Y.; LEVINE, H.; PEREIRA, L. V.; YANG, W. Aberrant patterns of X chromosome inactivation in bovine clones. Nature Genetics, v. 31, n. 2, p. 216-220, 2002.

YOUNG, L. E.; FERNANDES, K.; MCEVOY, T. G.; BUTTERWITH, S. C.; GUTIERREZ, C. G.; CAROLAN, C.; BROADBENT, P. J.; ROBINSON, J. J.; WILMUT, I.; SINCLAIR, K. D. Epigenetic change in IGF2R is associated with fetal overgrowth after sheep embryo culture. Nature Genetics, v. 27, n. 2, p. 153-154, 2001.

YOUNG, L. E.; SINCLAIR, K. D.; WILMUT, I. Large offspring syndrome in cattle and sheep. Reviews of Reproduction, v. 3, n. 3, p. 155-163, 1998.

ZHOU, Q.; RENARD, J. P.; LE FRIEC, G.; BROCHARD, V.; BEAUJEAN, N.; CHERIFI, Y.; FRAICHARD, A.; COZZI, J. Generation of fertile cloned rats by regulating oocyte activation. Science, v. 302, n. 5648, p. 1179, 2003.

ZHOU, W.; XIANG, T.; WALKER, S.; FARRAR, V.; HWANG, E.; FINDEISEN, B.; SADEGHIEH, S.; ARENIVAS, F.; ABRUZZESE, R. V.; POLEJAEVA, I. Global gene expression analysis of bovine blastocysts produced by multiple methods. Molecular Reproduction and Development, v. 75, n. 5, p. 744-758, 2008. 


\section{ANEXO A - Procedimentos Cirúrgicos de Canulação Cordonal e Infusão de Substratos Marcados, Seguido de Coleta de Amostras Sanguíneas}

\section{Procedimentos Cirúrgicos de Canulação de Vasos Sanguíneos Maternos e Fetais}

Cinco fêmeas bovinas sem raça definida (Bos taurus $\mathrm{X}$ Bos indicus), prenhes de embriões da raça Nelore produzidos in vivo foram alocadas individualmente em gaiolas metabólicas aos 205 dias de gestação, onde permaneceram por um período de 27 dias, com disponibilidade de espaço, água, feno de alfafa, ração peletizada (Bovino $\mathrm{M}^{\circledR}$ - Sano, SC, BR) e sal mineral ad libitum. Aos $220 \pm 1$ dia de gestação, os animais foram submetidos ao procedimento cirúrgico descrito por Ferrell (1991b), e exposto abaixo.

Após um jejum alimentar de $48 \mathrm{~h}$ e hídrico de $12 \mathrm{~h}$, os animais foram submetidos à pré-anestesia com $0,1 \mathrm{mg} / \mathrm{Kg}$ acepromazina por via intramuscular, seguida da indução anestésica com éter gliceril guaiacol (50 - $100 \mathrm{mg} / \mathrm{Kg}$ a 5\% em solução glicosada) por infusão intravenosa associada ao tiopental sódico $(10-15 \mathrm{mg} / \mathrm{Kg})$, com a intubação imediata com sonda endotraqueal de $22 \mathrm{~mm}$. A manutenção da anestesia foi realizada com anestesia inalatória com halotano (2-5\%) em um fluxo de oxigênio de 2-3 L/min, utilizando um circuito com reinalação parcial de gases. Para monitoração da pressão arterial e coleta de sangue arterial, foi colocado um catéter $22 \mathrm{G}$ na artéria central da orelha, o qual foi adaptado a um transdutor de pressão que permitiu a aferição das pressões arterial sistólica, diastólica e média.

Com o animal em decúbito dorsal, após o preparo do campo cirúrgico no abdômen e flanco, uma incisão na Linha Alba permitiu uma exteriorização parcial do útero gestacional. I. Vasos uterinos. Um catéter polivinílico $(230 \mathrm{~cm}$ de comprimento; $1,1 \mathrm{~mm}$ de diâmetro interno; 1,6 mm de diâmetro externo - TYGON ${ }^{\circledR}$ S-54-HL Microbore Tubing, K-mac Plastics, MI, EUA) foi inserido em uma artéria e outro em uma veia uterina isoladas imediatamente antes de sua primeira bifurcação no mesométrio do corno fetal; os catéteres foram suturados ao mesométrio; II. Vasos fetais e umbilicais. Uma histerotomia foi realizada entre os placentônios, e as membranas fetais individualizadas e divulsionadas. Uma sutura em forma de "bolsa de tabaco" foi preparada ao redor da abertura uterina, a fim de permitir sua posterior oclusão. Um dos membros pélvicos foi exposto através da abertura, e a artéria e veia femoral foram isoladas por dissecação, um catéter polivinílico (230 $\mathrm{cm}$ de comprimento; $0,7 \mathrm{~mm}$ de diâmetro interno; 1,2 mm de diâmetro externo) foi inserido em cada vaso e suturado à pele 
fetal. O cordão umbilical foi exposto, e uma incisão na fascia umbilical realizada perto do hilo umbilical. Um catéter (semelhante ao descrito para os vasos uterinos) foi inserido na veia umbilical no sentido placenta-feto. O catéter foi posicionado entre a fascia umbilical e a pele fetal e suturado 3-4 cm distante do hilo umbilical. A pele fetal e fascia umbilical foram suturadas, e o cordão umbilical recondicionado à cavidade amniótica. Ainda, $500 \mathrm{mg}$ de ampicilina foram administradas dentro da cavidade. A sutura em forma de "bolsa de tabaco" na parede uterina foi apertada, circunscrevendo os três catéteres, e uma sutura invaginante adicional foi realizada na linha de incisão. $O$ útero prenhe foi gentilmente reacomodado na cavidade abdominal. Os cinco catéteres previamente identificados foram transpassados por um orifício na região do flanco do animal e acondicionados em uma bolsa de couro suturada sobre o local de entrada. A incisão na Linha Alba foi fechada. Antes da inserção nos vasos sanguíneos, os catéteres foram preenchidos com uma solução salina contendo 1000 UI de heparina sódica/mL.

Todos os materiais utilizados foram previamente esterilizados a fim de garantir a assepsia do procedimento. Após o término cirúrgico, todos os animais foram extubados e colocados em decúbito external para recuperação, recebendo comida e água ad libitum. Os catéteres foram mantidos cheios, com solução salina heparinizada, com limpeza diária do orifício cutâneo e dos catéteres com algodão embebido em álcool iodado. Três doses de $10 \mathrm{x}$ $10^{6}$ UI de Benzilpenicilina benzatina (20000 UI/Kg de peso vivo, Penfort PPU ${ }^{\circledR}$, Ouro Fino) foram aplicadas com intervalos de dois, começando com um dia prévio ao procedimento cirúrgico. Antiinflamatório foi aplicado no dia do procedimento e nos dois que o seguiram com doses de $1,1 \mathrm{mg} / \mathrm{Kg}$ de Flunixina Meglumina (10 mL de Banamine ${ }^{\circledR}-$ Shering-Plough).

\section{Infusões Fetais e Maternas com Substratos Marcados e Coleta de Amostras Sanguíneas}

No dia $225 \pm 1$ de gestação, apenas duas das cinco fêmeas submetidas ao procedimento cirúrgico do dia 220 apresentavam fetos viáveis com a funcionalidade dos cinco catéteres, possibilitando a infusão de substratos marcados e coleta de amostras sanguíneas.

Uma dose inicial de $20 \mathrm{~mL}$ de óxido de deutério $\left(\mathrm{D}_{2} \mathrm{O}\right.$, Icon Isotopes, $\left.\mathrm{NJ}, \mathrm{EUA}\right)$ foi infundida no catéter de infusão fetal (veia femoral) por $10 \mathrm{~min}(\mathrm{t}=-60 \mathrm{~min})$, seguida de uma infusão constante $(0,2 \mathrm{~mL} / \mathrm{min})$ por um período de $7 \mathrm{~h}$ com o auxílio de uma bomba de infusão contínua hospitalar (Nutrimat $\left.\mathrm{II}^{\circledR}-\mathrm{B} / \mathrm{BRAUN}\right)$. No $\mathrm{t}=0 \mathrm{~h}(\mathrm{t}=0 \mathrm{~h}=$ infusão da 
glicose marcada), uma dose-pulso de $20 \mathrm{~mL}$ contendo $3 \mathrm{~g}$ de $\left[\mathrm{U}^{13} \mathrm{C}\right]$-glicose (Sigma - $\mathrm{n}^{\mathrm{o}}$ $389374)$ em solução salina $(0,9 \% \mathrm{NaCl})$ foi infundida na veia jugular materna e outra de $5 \mathrm{~mL}$

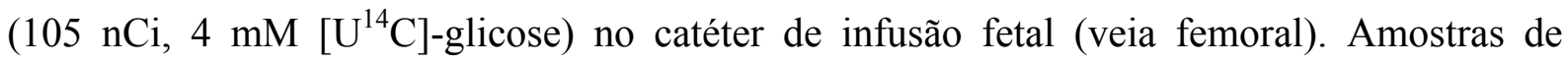
sangue foram coletadas pelos catéteres uterinos (artéria e veia), em um total de $10 \mathrm{~mL}$ para cada amostra, e dos catéteres umbilical (veia) e fetal (artéria) femoral, em um total de $5 \mathrm{~mL}$ para cada amostra. As amostras foram coletadas no $\mathrm{t}=-60$ e no $\mathrm{t}=0 \mathrm{~h}$ para a confirmação dos níveis estáveis de $\mathrm{D}_{2} \mathrm{O}$ nos sistemas materno e fetal, possibilitando a determinação dos fluxos sangüíneos umbilicais e uterinos, e para uso como amostras controle antes da infusão de substratos marcados. Amostras adicionais foram obtidas nos tempos 5, 15, 30, 45, 60, 90, 120, 180, 240, 300 e $360 \mathrm{~min}$. Este protocolo está ilustrado na figura 1 abaixo para melhor visualização e compreensão.

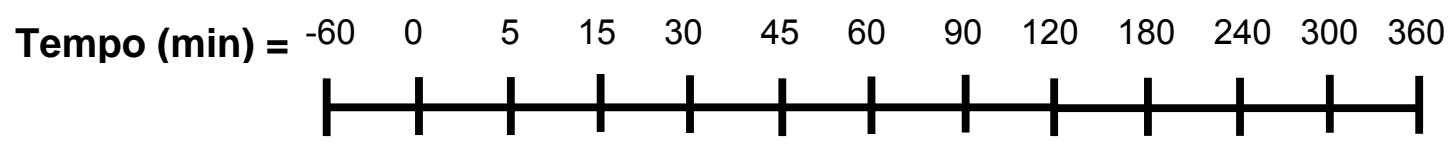

Dia $225 \pm 1$

Infusão constante de $\mathrm{D}_{2} \mathrm{O}$ na veia femoral fetal $(0,2 \mathrm{~mL} / \mathrm{min})$

Glicose marcada Materna $-3 \mathrm{~g}\left[\mathrm{U}-{ }^{13} \mathrm{C}\right] \mathrm{Glicose}$
Dose pulso de Glicose marcada

Glicose marcada Fetal - $105 \mathrm{nCi}\left[\mathrm{U}-{ }^{14} \mathrm{C}\right]$ Glicose

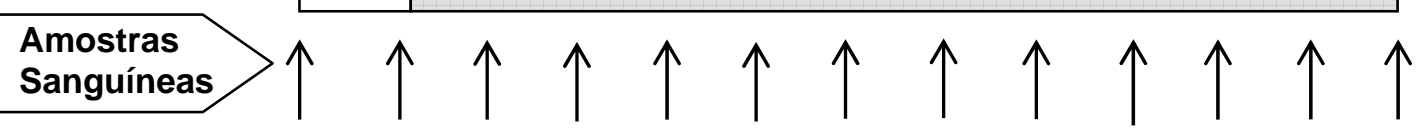

Figura 1 - Protocolo de infusão e amostragem dos sistemas materno e fetal em prenhezes de conceptos bovinos produzidos in vivo aos $225 \pm 1$ dia de gestação.

As amostras de sangue arterial e venoso, materno e fetal, coletadas nos diferentes tempos, foram processadas da seguinte maneira.

Amostras fetais oriundas dos catéteres fetais (artéria femoral e veia umbilical) e maternas oriundas dos catéteres uterinos (artéria e veia), 5 e $10 \mathrm{~mL}$, respectivamente, foram retirados de cada catéter ( $\mathrm{n}=13 /$ catéter) nos diferentes momentos, com auxílio de uma seringa previamente heparinizada.

Para o processamento das amostras fetais e maternas, 2,5 e $5 \mathrm{~mL}$ dos 5 e $10 \mathrm{~mL}$ totais obtidos para cada amostra, respectivamente, foram transferidos para um tubo cônico de centrífuga de $50 \mathrm{~mL}$ (Corning Incorporated) e processados visando a hemólise e desproteinização, e obtenção de um plasma composto por substratos e aminoácidos apenas.

Para a hemólise das amostras fetais e maternas, acrescentaram-se, respectivamente, 12,5 e $25 \mathrm{~mL}$, de água ultrapura MilliQ ${ }^{\circledR}$ (Millipore Corporation, MA, EUA) por 1 min, 
seguido de sua desproteinização pelo acréscimo de 5,0 mL ou $10 \mathrm{~mL}$ de $\mathrm{ZnSO}_{4}$ a 5\% e 0,3 N $\mathrm{Ba}(\mathrm{OH})_{2}$, homogeneizados e centrifugados por 15 min a $6000 \mathrm{~g}$ para obtenção do plasma. $\mathrm{O}$ sobrenadante foi alíquotado em tubos cônicos de centrífuga e congelados a $-80^{\circ} \mathrm{C}$ para posterior análise do $\mathrm{D}_{2} \mathrm{O}$, glicose, frutose, lactato e aminoácidos.

\section{ANÁLISES}

A identificação e quantificação dos substratos (glicose, frutose e lactato) serão conduzidas por espectrometria de massa e da concentração de $\mathrm{D}_{2} \mathrm{O}$ por espectrofotometria, em parceria com laboratórios especializados neste tipo de análises.

A diferença na concentração artério-venosa $(\mathrm{A}-\mathrm{V})$ plasmática $(\mathrm{mol} / \mathrm{L})$ será calculada para os substratos e $\mathrm{D}_{2} \mathrm{O}$. Os fluxos sanguíneos uterino e umbilical serão obtidos pela divisão da taxa de infusão do $\mathrm{D}_{2} \mathrm{O}$ pelos $\mathrm{A}-\mathrm{V}$ plasmáticos uterino e fetal para o $\mathrm{D}_{2} \mathrm{O}$. A absorção de nutrientes $(\mathrm{mol} / \mathrm{min})$ pelo tecido útero-placentário será calculada como a média do A-V $(\mathrm{mol} / \mathrm{L})$ para cada nutriente multiplicada pelo fluxo sanguíneo uterino ( $\mathrm{L} / \mathrm{min})$, e o fluxo total de nutrientes ao feto $(\mathrm{mol} / \mathrm{L})$ será determinado pela média do $\mathrm{V}-\mathrm{A}(\mathrm{mol} / \mathrm{L})$ para cada nutriente multiplicada pelo fluxo sanguíneo umbilical (L/min).

\section{RESULTADOS}

Os resultados das concentrações de $\mathrm{D}_{2} \mathrm{O}$ encontram-se em fase final de conclusão, e estão sendo conduzidas em parceria com o Laboratório de Ecologia Isotópica no Centro de Energia Nuclear na Agricultura da Escola Superior de Agronomia Luiz de Queiroz da Universidade de São Paulo em Piracicaba-SP. As análises de substratos ainda não foram encaminhadas para análises, mas a possibilidade de realização das mesmas em parceria com o laboratório Thomson do Instituto de Química da Unicamp em Campinas-SP é promissora e permitirá a finalização deste trabalho. 